\title{
Proceedings of the 12th Biennial Conference of Research on the Colorado Plateau
}



Scientific Investigations Report 2015-5180 
COVER

View from the North Rim of the Grand Canyon. Banner showing the San Francisco Peaks near Leupp, Arizona. Photograph by Robert J. Hart, U.S. Geological Survey.

ACKNOWLEDGMENT PAGE

Kanab Basin looking east. Photograph by Robert J. Hart, U.S. Geological Survey. 


\section{Proceedings of the 12th Biennial Conference of Research on the Colorado River Plateau}

Edited by Barbara E. Ralston

Scientific Investigations Report 2015-5180 


\section{U.S. Department of the Interior SALLY JEWELL, Secretary}

\section{U.S. Geological Survey Suzette M. Kimball, Director}

U.S. Geological Survey, Reston, Virginia: 2016

For more information on the USGS - the Federal source for science about the Earth, its natural and living resources, natural hazards, and the environment-visit http://www.usgs.gov or call 1-888-ASK-USGS.

For an overview of USGS information products, including maps, imagery, and publications, visit http://www.usgs.gov/pubprod/.

Any use of trade, firm, or product names is for descriptive purposes only and does not imply endorsement by the U.S. Government.

Although this information product, for the most part, is in the public domain, it also may contain copyrighted materials as noted in the text. Permission to reproduce copyrighted items must be secured from the copyright owner.

Suggested citation:

Ralston, B.E., ed., 2016, Proceedings of the 12th Biennial Conference of Research on the Colorado River Plateau: U.S. Geological Survey Scientific Investigations Report 2015-5180, 128 p., http://dx.doi.org/10.3133/sir20155180.

ISSN 2328-0328 (online) 


\section{Chapters}

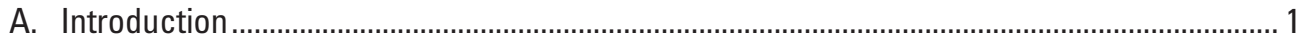

By Barbara E. Ralston

B. A Nine-Year Record of Dust on Snow in the Colorado River Basin ........................................... 3

By S. McKenzie Skiles and Thomas H. Painter

C. A Comparison of Historical and Future Rates of Climate Change in the Flagstaff Area of Northern Arizona ..........................................................................................

By Kenneth L. Cole

D. Ecological Inventory and Assessment of Springs Ecosystems in Kaibab National Forest, Northern Arizona ................................................................................................ 25

By Jeri D. Ledbetter, Lawrence E. Stevens, Marguerite Hendrie, and Arie Leonard

E. Fungal Diversity in Biological Soil Crusts of the Colorado Plateau.

By Blaire Steven, Cedar Hesse, La Verne Gallegos-Graves, Jayne Belnap, and Cheryl R. Kuske

F. Assembling a Virtual "Weevils of North America" Checklist with Symbiota-

Preliminary Insights

By Nico M. Franz, Charles W. O’Brien, Sarah D. Shirota, Michael T. Shillingburg, Chelsey R. Tellez, and Edward E. Gilbert

G. Influence of Habitat and Region on Spider Communities Along Two Elevation

Gradients in the Southwestern U.S.

By Sandra L. Brantley, Caitlin A. Chapman, and Neil S. Cobb

H. Effects of Changing Lake Level on Lake Powell Fisheries-A Hypothesis 73

By A. Wayne Gustaveson

I. Understanding Forest Restoration Effects on Water Balance-Study Design for the Four Forest Restoration Initiative Paired Watershed Study...

By Frances C. O'Donnell, Sharon Masek Lopez, and Abraham E. Springer

J. Long-Term Post-Wildfire Correlates with Avian Community Dynamics in Ponderosa Pine Forests.

By Jamie S. Sanderlin, William M. Block, and Brenda E. Strohmeyer

K. Hunting Methods and Harvest Demographics for Black Bears in Arizona, 1981-2011 ...... 103 By Brian F. Wakeling

L. Visitor-Use Impacts and Habitat Associations of the Avifauna Occupying the Colorado River Corridor in Grand Canyon National Park .

By Valerie J. Horncastle, Brett G. Dickson, and Todd A. Chaudhry

M. Bat Surveys in Pipe Spring National Monument and Ensuing Interpretive Programs 123

By Cameron Jack, John R. Taylor, Andrea Bornemeier, and Amber VanAlfen 


\title{
Acknowledgments
}

\section{Volume Editor}

Barbara E. Ralston

U.S. Geological Survey, Flagstaff, Arizona

\section{Managing Editor}

Kate Jacques

U.S. Geological Survey, Menlo Park, California

\section{Chapter Editors}

\author{
Regan Austin \\ U.S. Geological Survey, Menlo Park, California \\ Jessica L. Dyke \\ U.S. Geological Survey, Menlo Park, California \\ James W. Hendley II \\ U.S. Geological Survey, Menlo Park, California \\ Claire M. Landowski \\ U.S. Geological Survey, Menlo Park, California
}

\section{Production Staff}

Jeanne S. DiLeo

U.S. Geological Survey, Menlo Park, California

\section{Research Assistant}

Meredith A. Hartwell

U.S. Geological Survey, Flagstaff, Arizona

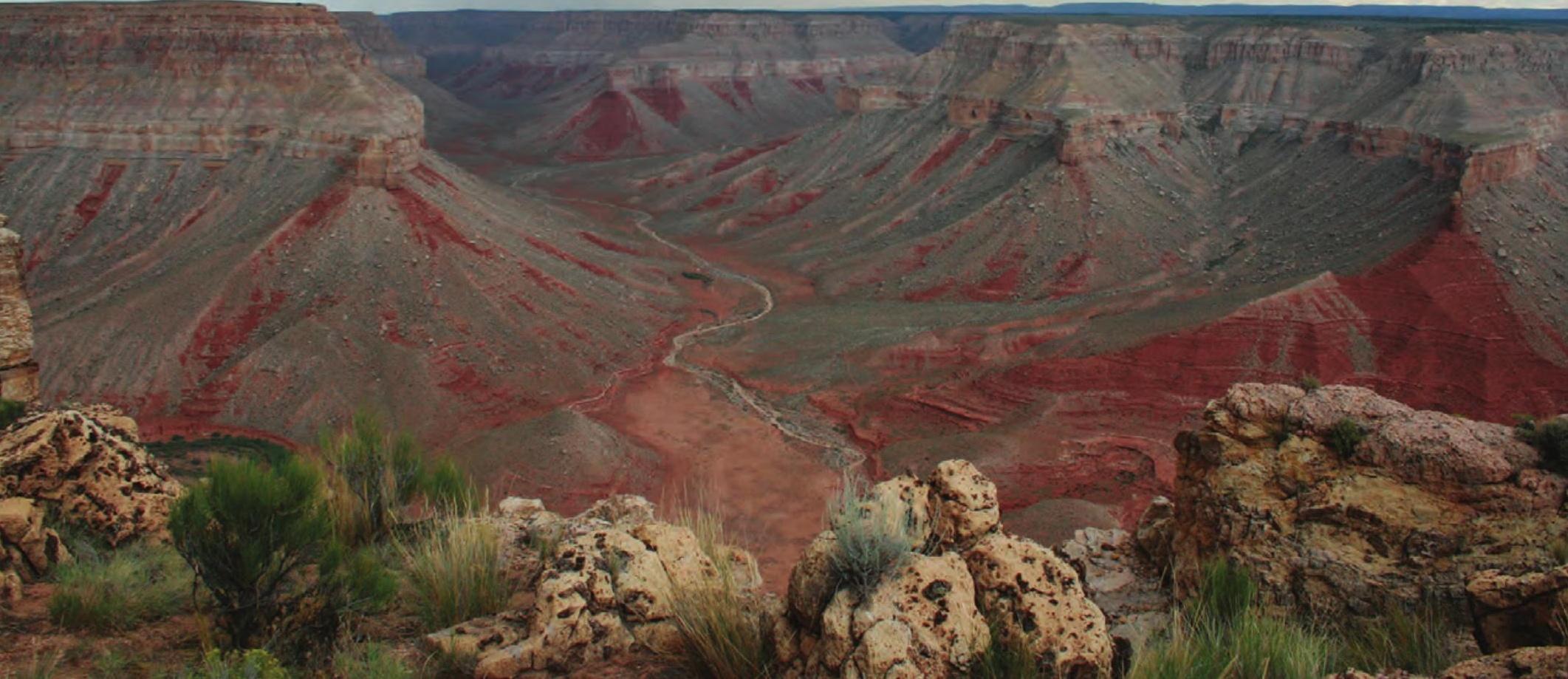




\title{
Chapter A
}

\section{Introduction}

\author{
By Barbara E. Ralston ${ }^{1}$
}

The Colorado Plateau is a physiographic region that encompasses 330,000 square kilometers in parts of four states in the southwestern United States (Colorado, Utah, New Mexico, and Arizona). Known for its high deserts, the Colorado Plateau also includes isolated mountains, high plateaus, and rugged canyons. Not only is the region topographically diverse, but geologically, biologically, and culturally diverse as well. The landscape is managed by Federal entities including the Bureau of Land Management, the National Park Service, and the U.S. Forest Service; Tribal nations including the Navajo Nation, Kaibab Paiute, Mountain Ute, Southern Ute, Hopi, Zuni, Hualapai, Havasupai, and White Mountain Apache Tribes; State land and wildlife management agencies; and privately owned holdings, creating complex interactions and management challenges (fig. 1). Population growth, increased tourism to Federal and State lands, and energy development have increased water demands and altered land-use patterns, and these changes have emerged as management challenges facing the people working and living in the region. Climate change, particularly the ongoing drought, has exacerbated the effects of population growth, land-use change, and other stressors such as invasive species. As managers seek solutions to the challenges facing the region's natural and cultural resources, the Biennial Conference of Science and Management of the Colorado Plateau has become an important venue for exchanging information about emerging management concerns and recent scientific research. Each biennial conference has sought to promote discussion, information sharing, and productive communication among the managers, scientists, students, administrators, tribal representatives, and others who attend the conference with the goal of enhancing the use of the best available science to manage the region's incomparable natural and cultural resources.

The publication and dissemination of a conference proceedings series expands the reach of the conference beyond those people in attendance and creates a record on the research presented. The idea of producing a conference proceedings, and its subsequent publication, first occurred in 1993 following the first biennial conference in 1991. A published volume of contributed papers has followed each subsequent biennial conference, including this volume. The venue for publishing proceedings has changed over the years and has included the National Park Service, the Government Printing Office, the

'U.S. Geological Survey
U.S. Geological Survey, and University of Arizona Press. Recently, van Riper and others (2015) published a compilation of the abstracts from the 11 previous conference proceedings. Collectively, the proceedings highlight approximately 25 years of natural- and cultural-resources research, promoting the integration of research with resource management across the Colorado Plateau. This volume is freely downloadable by the public, thereby further expanding the influence of this conference beyond the Colorado Plateau.

The 12th Biennial Conference held in Flagstaff, Arizona, from September 16 to 19, 2013, covered a range of topics in the physical, biological, and socio-cultural sciences. The conference was organized and hosted by Northern Arizona University's (NAU) Merriam-Powell Center for Environmental Research, the Colorado Plateau Cooperative Ecosystem Studies Unit, and the U.S. Geological Survey (USGS) Southwest Biological Science Center. Financial and in-kind support was provided by a wide range of organizations including the U.S. Forest Service, National Park Service, Bureau of Land Management, Grand Canyon Trust, Colorado Plateau Research Station, and various NAU entities. NAU sponsors include the Landscape Conservation Initiative, School of Forestry, School of Earth Science and Environmental Sustainability, Office of the Provost, and Office of the Vice President of Research. Contributors to these proceedings include researchers and managers from Federal, State, and Tribal governments, universities, private entities, and non-profit organizations. In this regard, this conference has wide-ranging support and participation among private and public entities involved in the science and management of natural resources on the Colorado Plateau.

Topics at the conference included broad subject sessions in animal, plant, and fire ecology, and special topical sessions that included piñon-juniper woodland health, arthropod biodiversity, biological soil crusts, and climate change mitigation and adaptation. The 12 contributed papers appearing in this volume represent a subset of topics presented at the conference. The order of articles follows a progression from the physical sciences to biology, and ends with the outcomes of research used in an interpretive setting. Each paper in this biennial conference proceedings represents original research that is previously unpublished and has been peer reviewed by scientists familiar with the subject matter.

Numerous people contributed to the success of both the conference and this proceedings volume. In particular, Lara Schmit, the conference coordinator, and Ron Hiebert, my conference co-chair, helped identify special session organizers, 
Proceedings of the 12th Biennial Conference of Research on the Colorado Plateau

developed the conference agenda, and worked with NAU's conference staff to find a location that accommodated the conference and all of the presentations. Volunteers from both NAU and the USGS moderated sessions. Peer reviewers provided insightful and critical comments that improved all of the submitted manuscripts. Additionally, the copy editors with the USGS Science Publishing Network provided outstanding editorial oversight. As with previous publications of the conference proceedings, the USGS provided financial support. In this case, David Lytle, the Director of the Southwest Biological Science Center, provided on-going support for the completion of this volume.

\section{Reference}

van Riper, C., III, Drost, C.A., and Selleck, S.S., compilers, 2015, A quarter century of research on the Colorado

Plateau-A compilation of the Colorado Plateau Biennial Conference proceedings for 1993-2015: U.S. Geological Survey Open-File Report 2015-1115, 186 p., http://dx.doi. org/10.3133/ofr20151115.

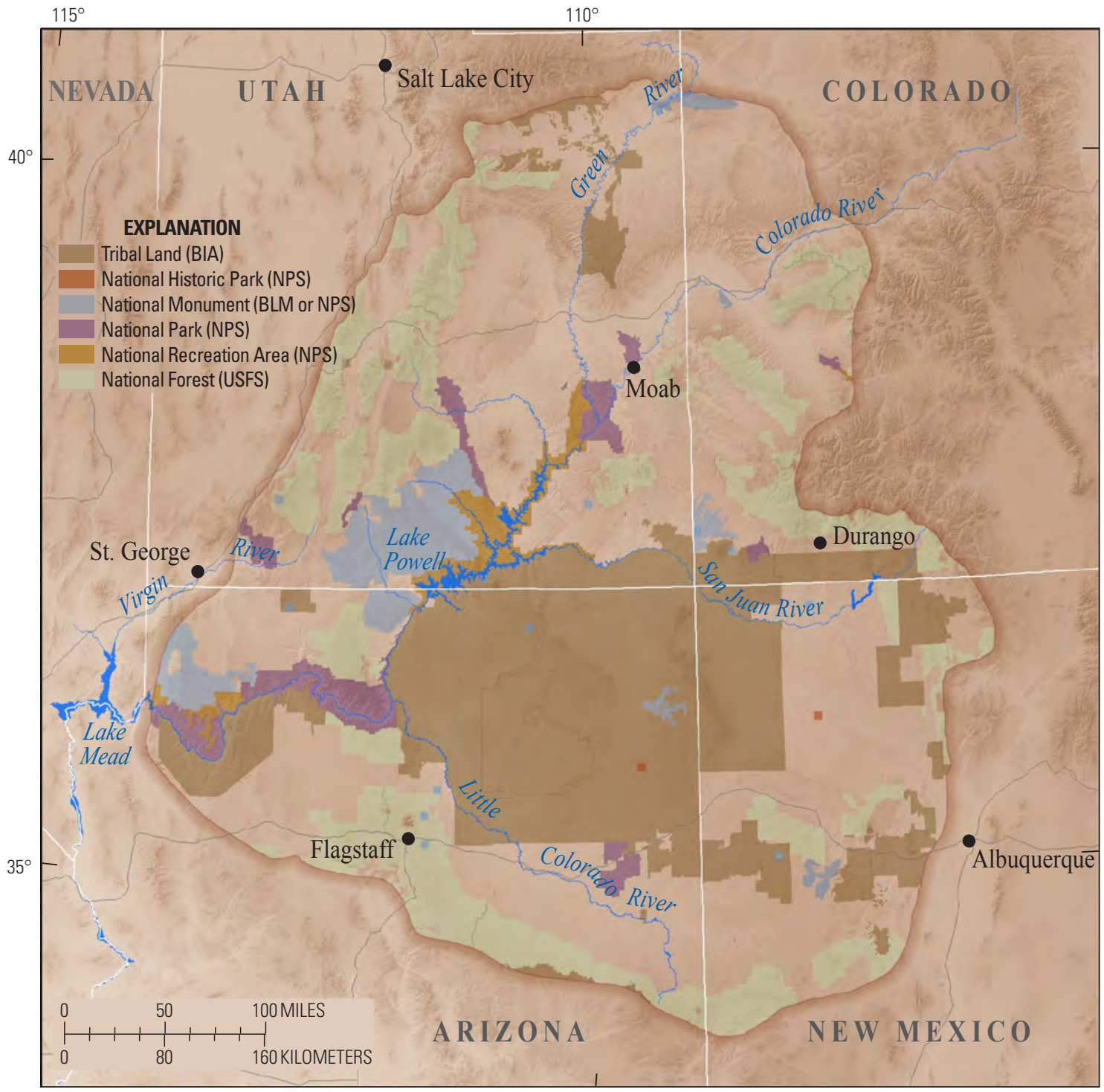

Figure 1. Map identifying the extent of the Colorado Plateau that covers parts of Arizona, Colorado, New Mexico and Utah with National Parks, Monuments, Historic Sites, Recreation Areas, and Forests, as well as Tribal land boundaries identified. (NF, National Forest; NHS, National Historic Site; NM, National Monument; NP, National Park; NRA, National Recreation Area) 


\title{
A Nine-Year Record of Dust on Snow in the Colorado River Basin
}

\author{
By S. McKenzie Skiles ${ }^{1}$ and Thomas H. Painter ${ }^{1}$
}

\section{Abstract}

Mountain snow cover of the Colorado River Basin (CRB) has had a fivefold increase in dust loading since Anglo settlement of the western United States in the mid-19th century. This dust deposition accelerates snowmelt by reducing albedo through surface darkening and enhanced snow grain growth. Here we present a nine-year (water years [WY] 2005-2013) record of dust loading and advanced snowmelt at Senator Beck Basin Study Area, San Juan Mountains, Colorado (SBBSA). Since observations of dust events began in WY 2003, a single dust-free season has not occurred. The majority of these dust events occur in the spring, which enhances the efficacy of dust-advanced snowmelt, as it coincides with increasing solar irradiance. The fewest springtime events occurred in WY 2003 (three events) and then increased through WY 2008 (nine events) before stabilizing with an average of $9 \pm 1$ spring events between 2008 and 2013. The amount of dust entrained and deposited in each event is variable; therefore, the number of dust events is not a good indicator for dust loading, which exhibits greater interannual variability. End of snow season total dust concentrations range from 0.2 to 4.8 milligrams of dust per gram of snow melt water $(\mathrm{mg} / \mathrm{g})$, resulting in earlier snowmelt by 3 to 7 weeks. Results from snowmelt modeling show that the degree of advanced melt is linearly related to the amount of dust deposited each season.

\section{Introduction}

The Colorado Plateau region of the western United States is one of the main dust producers in North America (Neff and others, 2008). Southwesterly winds entrain sediment from this region and deposit it downwind in the snow-covered Colorado Rocky Mountains. Remote sensing imagery, back-trajectory analysis, and chemical analysis of dust in snow from the San Juan Mountains in southwestern Colorado indicate that the dust source is the Colorado Plateau, namely the lowland arid landscapes of the Four Corners Region (Lawrence and

\footnotetext{
${ }^{1}$ Jet Propulsion Laboratory, California Institute of Technology
}

others, 2010; Neff and others, 2008; Painter and others, 2007). Understanding the impact of dust deposition onto snow cover in this region is of interest because snowmelt is a critical resource that contributes to more than 70 percent of the flow in the Colorado River, an overallocated river that provides water to seven states in the western United States and to Mexico. Additionally, the current level of dust loading is a relatively new phenomenon in this region. Sediment cores from high elevation lakes in the San Juan Mountains show that dust deposition rates have increased fivefold over background since Anglo settlement and grazing disturbance of the western United States in the mid19th century (Neff and others, 2008).

Dust radiative forcing is defined as the instantaneous enhanced surface absorption of solar radiation by dust deposited in snow (Painter and others, 2007). This impact is direct, enhancing absorption of solar radiation by darkening the snow surface, and indirect, enhancing absorption by accelerating grain growth (Painter and others, 2007). As snow absorption increases, snow albedo is reduced further, and a feedback process is initiated. The additional energy supplied by dust radiative forcing has been shown to advance melt by 3 to 7 weeks, shift timing and intensity of peak runoff, and reduce total water yield (Painter and others, 2010; Skiles and others, 2012). Ongoing research indicates that not accounting for dust radiative forcing may be a factor contributing to operational river runoff forecast errors in the Colorado River Basin (CRB) (Bryant and others, 2013).

\section{Previous Work}

In 2005, two snow energy balance instrumentation array towers were installed in Senator Beck Basin Study Area (SBBSA), San Juan Mountains, Colorado. These instrumentation arrays, along with another tower on Grand Mesa in west-central Colorado installed in 2009, are the only full snow energy balance towers in the Colorado River Basin that allow for energy balance based snowmelt modeling. This record is highly valuable in a region that depends so heavily on snow for water resources. Painter and others (2007) utilized this data to isolate the effects of dust from other controls and show that the acceleration of melt by the shortwave radiative forcing of dust results in a shortening of snow cover duration in this region by about a month. 
Proceedings of the 12th Biennial Conference of Research on the Colorado Plateau

Skiles and others (2012) expanded this analysis to assess the interannual variability in dust loading, radiative forcing, and snowmelt rates over a 6-year record (20052010); mean springtime dust radiative forcing across the period ranged from 31 to 75 watts per square meter $\left(\mathrm{W} / \mathrm{m}^{2}\right)$, shortening snow cover duration by 21 to 51 days. The dustadvanced loss of snow cover was found to be linearly related to total dust concentration at the end of snow cover, despite temporal variability in dust exposure and solar irradiance. The advanced melt owing to dust resulted in faster and earlier peak snowmelt outflow, with daily mean snowpack outflow doubling under the heaviest dust conditions. Skiles and others (2012) also compared the relative capacity of dust and warmer temperatures to advance melt and found dust efficacy to be greater: increases of $2-4{ }^{\circ} \mathrm{C}$ advanced melt by $5-18$ days in the absence of dust and $0-6$ days in the presence of dust.

\section{Current Work}

The current work is designed to be an update to, and supplement, the dust-on-snow data record presented in Painter and others (2007) and Skiles and others (2012), and the reader is referred to these papers for additional discussion and detail on methods. Here, we expand on these studies to encompass the full observation period at SBBSA study sites, from 2005 through 2013. Interannual variability in dust deposition and loading is assessed from the snow observations and sampling record. Interannual variability in dust radiative forcing and advanced snowmelt is assessed from the radiative forcing and snowmelt reconstruction modeling.

\section{Methods}

\section{Study Area}

Senator Beck Basin Study Area is in the Ouray Ranger District of the Uncompahgre National Forest in the western San Juan Mountains of southwestern Colorado (location within the Colorado River Basin is shown in fig. 1). The study area is managed by the Center for Snow and Avalanche Studies (CSAS). Observations of dust events began during WY 2003 (October 2002 through September 2003), and two meteorological and energy-flux instrumentation towers were installed in early WY 2005.

The instrumentation towers are located within dedicated study plots, where regular snow sampling also takes place. Senator Beck Study Plot (SBSP, fig. 1) is located in the alpine tundra (3,719 meters $[\mathrm{m}])$ above tree line at a level site near the center of SBBSA. Swamp Angel Study Plot (SASP, fig. 1) is located in a clearing below tree line in a subalpine forest at $3,368 \mathrm{~m}$. Hereafter, SBSP is referred to as the "alpine site" and SASP as the "subalpine site."
Measurements from the instrumentation towers are used to determined dust radiative forcing and reconstruct snowmelt, as described below. Measured parameters include wind speed and direction, air temperature and relative humidity, snowpack depth, incoming and outgoing broadband (BB) solar radiation, incoming and outgoing near infrared/shortwave infrared (NIR/SWIR) solar radiation, and incoming longwave radiation. Incoming and outgoing visible (VIS) radiation is the difference between the BB and NIR/ SWIR. Snow albedo is the ratio of incoming to outgoing solar radiation. Outgoing longwave radiation is inferred from measurement of snow surface temperature from an infrared sensor. Precipitation is measured at the subalpine site by a standalone precipitation gauge but is not measured at the alpine site owing to the high winds. A more detailed description of these sites and data can be found in Painter and others (2012) and Landry and others (2014). Data from these sites are publically available by the CSAS at http://www. snowstudies.org/.

\section{Observations and Snow Sampling}

The presence of airborne dust over the study area and subsequent deposition in the snow, referred to as dust events, are visually identified and recorded by CSAS. The evolution of dust layers, and snow properties, are monitored through snowpit measurements that take place within study plot boundaries. The measurements are collected once a month during the winter, when few dust events occur and snow is accumulating, and then increases to weekly in the spring, when the majority of dust deposition occurs and snowmelt begins. Snow sampling is more frequent at the subalpine site, which is easier to access. Snowpits are excavated to the ground, and measurements include the following: snow depth, 10-centimeter $(\mathrm{cm})$ temperature profile, visual notation of snow and dust stratigraphy, liquid water content, and snow density. Depth and density measurements are used to calculate snow water equivalent (SWE), the hydrologically relevant variable that describes how much water is contained within the snowpack.

In addition to snow observations, snow samples are collected in snowpits when dust is at or near the surface to quantify dust concentrations that may be impacting albedo and radiative forcing. Samples are collected in the top $30 \mathrm{~cm}$ of the snow column, across a horizontal area of $500 \mathrm{~cm}^{2}$, at $3-\mathrm{cm}$ intervals. Because of the attenuation of incident solar radiation in snow surface layers, $30 \mathrm{~cm}$ is the estimated maximum depth to which dust influences snow albedo (Warren and others, 1982). The $3-\mathrm{cm}$ sampling interval is useful to capture dust layers, which tend to be thin. Consistent sampling volumes, maintained using a gravimetrics board, allow for a consistent comparison between collections/years. Dust is typically not entrained in melt, and end-of-year (EOY) dust concentrations are reported from samples collected just prior to snow depletion, when the majority of dust has combined at the surface. Additional dust was not deposited in the time between 
the last sample collection and snow all gone (SAG) in any year of the study.

Snow samples $\left(3 \mathrm{~cm} \times 500 \mathrm{~cm}^{2}\right)$ are melted, stored individually in Nalgene bottles, and sent to the Snow Optics Laboratory at National Aeronautics and Space Administration's (NASA's) Jet Propulsion Laboratory, where each sample is filtered through preweighed 0.495 -micrometers $(\mu \mathrm{m})$-diameter Nuclepore filters. After filters have dried, they are reweighed to find dust mass. Dust concentrations are reported in milligram of dust per gram of snow sample $(\mathrm{mg} / \mathrm{g})$, which is equivalent to parts per thousand by weight (pptw).

\section{Dust Radiative Forcing Modeling}

Solar radiation measurements at the instrumentation array towers allow us to determine the range of potential radiative forcing owing to dust, using the treatment described in Painter and others (2007). Briefly, to bracket the potential dust impact, radiative forcing (in $\mathrm{W} / \mathrm{m}^{2}$ ) is calculated by way of two scenarios. The minimum impact scenario addresses the direct effect of absorption by dust in snow:

$$
\mathrm{F}_{d \min }=E_{v i s} \Delta_{v i s}
$$
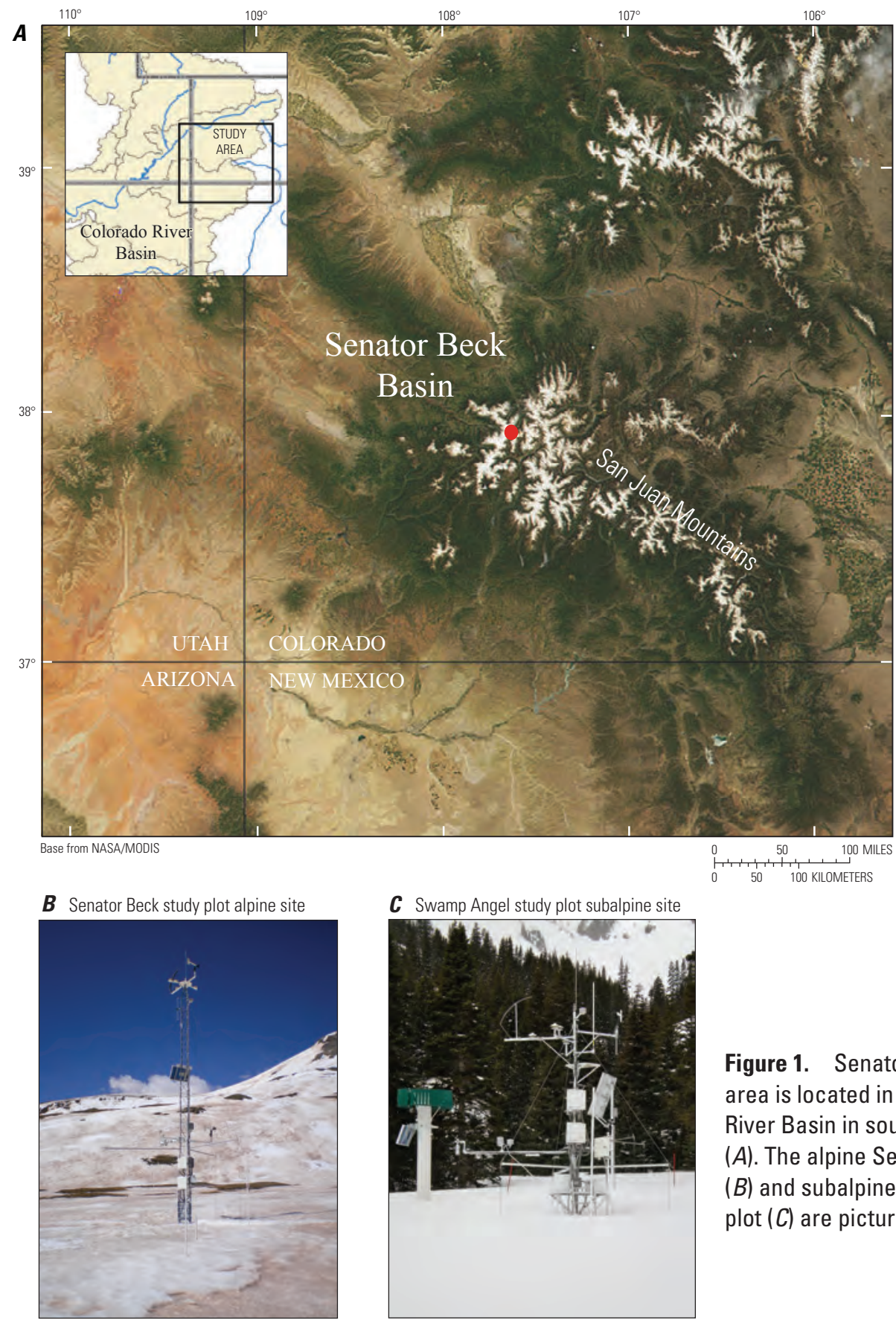

C Swamp Angel study plot subalpine site

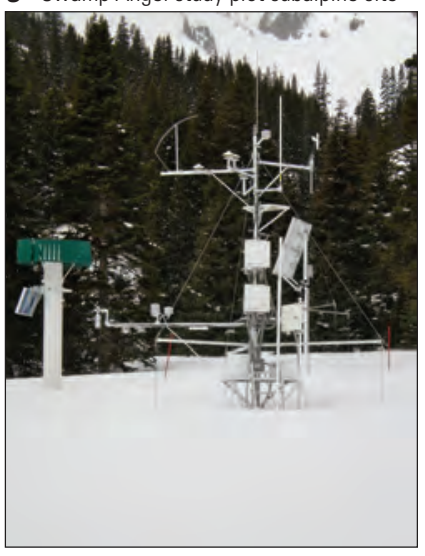

Figure 1. Senator Beck Basin Study area is located in the upper Colorado River Basin in southwestern Colorado (A). The alpine Senator Beck Study Plot $(B)$ and subalpine Swamp Angel study plot $(C)$ are pictured. 
Proceedings of the 12th Biennial Conference of Research on the Colorado Plateau

where $E_{v i s}$ is visible irradiance $\left(\mathrm{W} / \mathrm{m}^{2}\right)$ and $\Delta_{\text {vis }}=0.92-\alpha_{v i s}$, where $\alpha_{v i s}$ is measured visible albedo and 0.92 is the mean visible albedo for relatively dust-free snow at SBBSA (Painter and others, 2007).

The maximum impact scenario addresses both the direct effect and the indirect effects of dust on snow by also accounting for changes in grain size, using an empirical relationship developed at SBBSA that gives the proportion of the change in NIR albedo owing to the presence of dust versus grain growth in the absence of dust:

$$
\mathrm{F}_{d \max }=0.5\left(E_{v i s} \Delta_{v i s}+E_{n i r} \alpha_{n i r}((1 / \xi)-1)\right)
$$

where

$$
\begin{aligned}
& \text { if } \Delta_{\text {vis }} \leq 0.17, \text { then } \xi=1-1.689 \Delta_{\text {vis }} ; \\
& \text { if } \Delta_{\text {vis }} \geq 0.17 \text {, then } \xi=0.67 ; \\
& E_{\text {nir }} \text { is the NIR/SWIR net shortwave flux; and } \\
& \alpha_{\text {nir }} \text { is the NIR/SWIR albedo (Painter and } \\
& \text { others, 2007). }
\end{aligned}
$$

\section{Snow Energy Balance and Melt Modeling}

Dust radiative forcing (RF) can change timing and intensity of snowmelt runoff and reduce total water yield. To estimate the influence of dust on snowmelt, the depletion of SWE is modeled in the presence and absence of dust using the snow energy balance snowmelt model, SNOBAL (Marks and others, 1998). The presence of dust represents observed conditions and is modeled from energy balance measurements directly. The absence of dust represents a clean snowpack, which is modeled by removing the minimum and maximum RF owing to dust from net solar radiation, then averaging the daily values of these two scenarios to represent a conservatively clean snowpack. Snowmelt is modeled from April 15, the average date of peak SWE at SBBSA, to capture snowmelt evolution and SWE depletion over the ablation season (the time period between peak SWE and SAG).

The SNOBAL model, which reconstructs snow cover evolution from snow energy balance measurements, was first described conceptually by Marks and Dozier (1992) and then described in detail by Marks and others (1998). Both the model and modeling process are described in greater detail in Skiles and others (2012), along with a site-specific sensitivity analysis. Briefly, changes in snow depth and density (SWE) and point runoff are predicted by SNOBAL using snow properties (temperature, density, and water content), energy exchanges from the instrumentation towers (net solar radiation, incoming longwave radiation, air temperature, wind speed, and vapor pressure), precipitation, and tower measurement heights. Dust and dust-free (clean case) model runs are initiated with measured snow properties from the snowpit, which is excavated closest in time to April 15 and run at an hourly time step until complete snowmelt is achieved.
The only variation between scenarios is net solar radiation, which is altered in the clean case to remove dust radiative forcing. Thus, the difference between when the dust scenario and clean scenario time series reach SAG indicates the number of days that dust radiative forcing advances complete melt under observed meteorological conditions. Snowpack evolution is reconstructed well by SNOBAL over the ablation season; on average, modeled dust scenario SAG occurs within a day of observed SAG across all years.

\section{Results and Discussion}

\section{Dust Deposition and Loading}

Since 2003, a total of 87 dust events have been recorded during the presence of snow cover in SBBSA. An average of eight events per water year occur when snow cover is present, although events are not evenly distributed (fig. 2). The fewest events occurred in 2003 and 2004, with three events each season. The number of events exhibited an increasing trend through 2009, when the number of events peaked at 12 . From 2009-2013, the number varied between 9 and 12 events. Although there is a clear increase in the number of events per season, it is possible that this is an artifact of improving recognitions of dust events. It is not possible to draw any conclusions about long-term trends because the data record is still relatively short.

Dust events are not distributed evenly across the snow cover season; 80 percent of them occur in March, April, and May (fig. 2). This is not unexpected. The drying of semiarid landscapes and increased wind speeds (owing to atmospheric momentum exchange) coincide in the spring and thereby increase dust emission and dust event frequency at that time. The number of springtime events follows a similar pattern to total number of events per season throughout the study period, increasing from 2003-2008 and then becoming less variable over the last 5 years with an average of $9 \pm 1$ events each spring.

The timing of dust deposition is important for the radiative impact. Dust deposited in the spring has the greatest impact because solar irradiance is increasing and the internal energy in the snow pack is great enough to initiate snowmelt. Additionally, dust remains in the layer in which it was deposited and is not entrained in melt water, a process which results in newly deposited spring dust layers persisting at the surface and previously buried layers resurfacing and converging as snow cover is depleted, darkening the surface and compounding albedo decay. The stationary behavior of dust layers as snow melts has been consistently observed at SBBSA and has also been reported for light-absorbing impurities in other regions (Conway and others, 1996; Doherty and others, 2013). 
End-of-year dust concentrations exhibit greater interannual variability than number of seasonal dust events because the amount of dust entrained in each event is variable; the number of events each season is therefore not a predictor of total dust loading (fig. 3). Although still a relatively short data record, it appears that seasonal loading is roughly $1.0 \mathrm{mg} / \mathrm{g}$ or less in most years (2005-2008, 2011-2012). In these years, seasonal dust loading ranges from 0.2 to $1.3 \mathrm{mg} / \mathrm{g}$ and averages $0.8 \mathrm{mg} / \mathrm{g}$ at the subalpine site, and at the alpine site, it ranges from 0.3 to $1.1 \mathrm{mg} / \mathrm{g}$ and averages $0.7 \mathrm{mg} / \mathrm{g}$. In the other years, dust loading is more extreme $(2009,2010$, and 2013), ranging from 4.3 to $4.8 \mathrm{mg} / \mathrm{g}$ and averaging $4.6 \mathrm{mg} / \mathrm{g}$, which is five times the average dust loading in the lower dust years. Concentrations of dust at the windy alpine site tend to be slightly lower than the subalpine site, with an average concentration of $3.6 \mathrm{mg} / \mathrm{g}$ in the higher dust years.

The highest end-of-year dust concentration was sampled in 2013 , with $4.8 \mathrm{mg} / \mathrm{g}$ at the subalpine site; the next highest

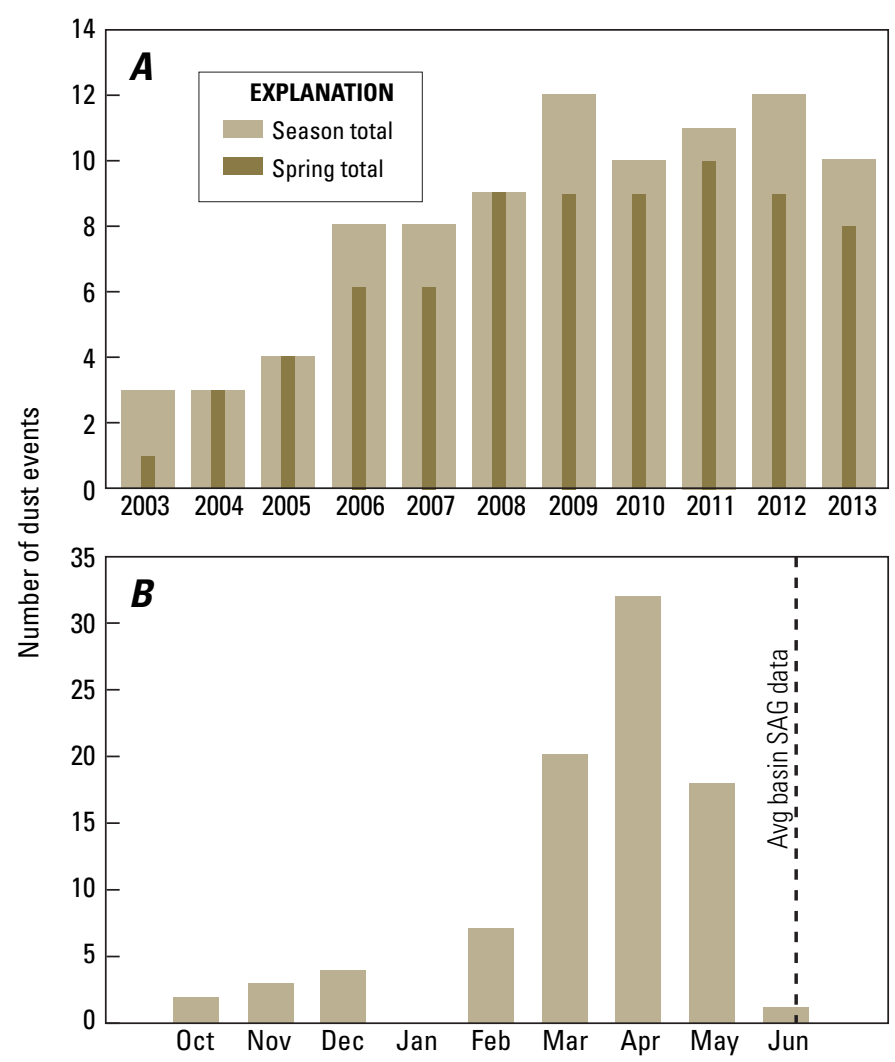

Figure 2. Bar graphs showing observed dust events in Senator Beck Basin Study Area in the San Juan Mountains of southwestern Colorado, from 2003 to 2013. A, The number of observed dust events (2003-2013). B, Monthly distribution of these events over the full record. The months of August and September are not shown in the distribution plot because dust events are not recorded when snow cover is absent. The basinwide average date of snow all gone (SAG) is shown by the dotted line. dust concentration year, 2009, had an end-of-year dust concentration of $4.6 \mathrm{mg} / \mathrm{g}$ at the subalpine site. Because of high avalanche danger, the alpine site was inaccessible for an end-of-year sample in 2013. The variation in dust loading between alpine and subalpine is greatest in heavy dust loading years, with an average difference of $-1.2 \mathrm{mg} / \mathrm{g}$ for 2009 and 2010, whereas if you average across all 9 years, the difference minimizes to $-0.4 \mathrm{mg} / \mathrm{g}$. Therefore, the end-of-year dust concentration at the alpine site in 2013 is estimated to be between 3.6 and $4.4 \mathrm{mg} / \mathrm{g}$.

It is outside the scope of this paper to discuss in detail the potential source for this high interannual variability in dust loading, which could relate to surface dynamics in the source region and synoptic meteorology. A recent study by $\mathrm{Li}$ and others (2013) found a relation between the amounts of bare ground, as identified from remote sensing imagery, and dust loading at SBBSA. Likely, heavy dust years cannot be attributed to a single factor, and additional study is needed better understand the relation between source region, atmospheric transport, and deposition processes.

\section{Dust Radiative Forcing}

Dust radiative forcing typically initiates in March with the deposition of spring dust events and increases through the ablation season with additional dust deposition, increasing irradiance, and snow albedo feedbacks. To capture the rise

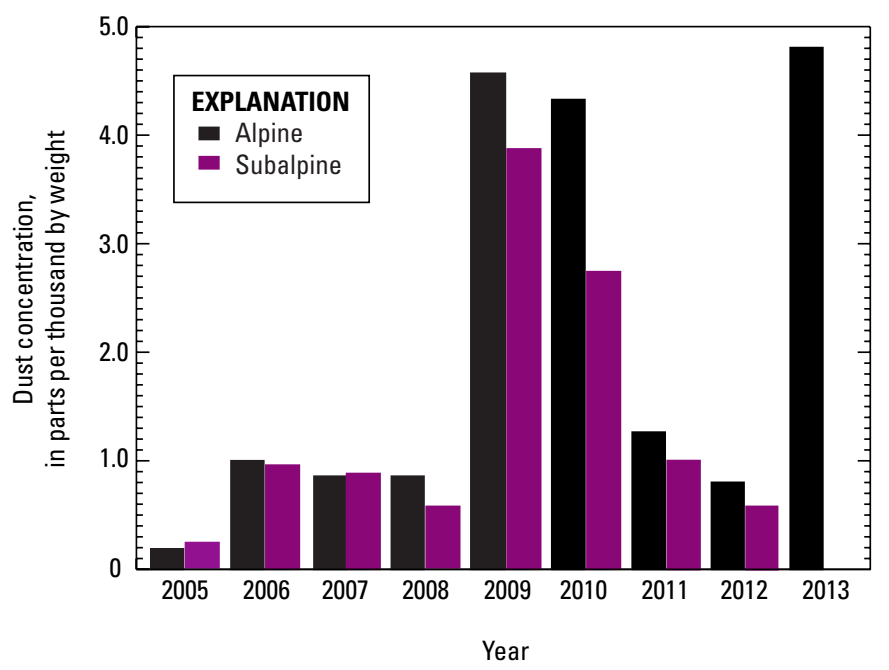

Figure 3. Bar graph showing sampled end-of-year dust concentrations in parts per thousand by weight (pptw, mg/g equivalent) at Senator Beck Basin Study Area in the San Juan Mountains of southwestern Colorado. The alpine site is located in the upper basin in alpine tundra above tree line, and the subalpine site is located in the lower basin below tree line. 
Proceedings of the 12th Biennial Conference of Research on the Colorado Plateau

in spring radiative forcing, it is calculated each year from March 15 to the date of modeled clean SAG. The average of the two RF scenarios (max/min) is plotted for 2011-2013 at the subalpine site as daily means along with broadband albedo, dust events, and modeled/measured snow water equivalent evolution in figure 4. Similar plots for 2005-2010 can be found in Skiles and others (2012).

Snow albedo typically decreases, and radiative forcing increases, with or shortly after a dust event, although not all dust deposition events increase RF immediately. Dry events, those not associated with precipitation, result in the quickest reduction in albedo because they can interact with solar irradiance directly upon deposition. The impact of events that occur just ahead of or during precipitation events are dampened by new snow, and radiative forcing increases as the new snow increases in grain size (no longer dominating attenuation) or as it melts (bringing the dust layer closer to the surface). On a seasonal scale, RF increases steadily in the spring as previously buried dust layers converge at the snow surface, and the largest RF values occur at the end of the season just prior to SAG.
Average radiative forcing between April 15 and observed SAG gives an indication of how much additional energy dust is contributing toward melts over the ablation season (table 1).

The highest daily mean RFs over this time period occur in the extreme dust years, ranging from 58 to $75 \mathrm{~W} / \mathrm{m}^{2}$ at the subalpine site. Although 2013 had a higher end-of-year dust concentration, 2009 had a higher ablation season RF because the lack of new snow and absence of cloud cover (both factors that influence radiative forcing magnitude) reduced snow albedo to below 0.35 , unprecedented values, for the final 11 days of snow cover. This resulted in an average RF of $125 \mathrm{~W} / \mathrm{m}^{2}$ during the last 7 days of snow cover, whereas $\mathrm{RF}$ was $108 \mathrm{~W} / \mathrm{m}^{2}$ over this same time period in 2013 (when snow albedo fell below 0.35 for the final 5 days). The lower dust concentration years (2005-2008, 2011-2012) have a daily mean $\mathrm{RF}$ of $50 \mathrm{~W} / \mathrm{m}^{2}$, ranging from 45 to $56 \mathrm{~W} / \mathrm{m}^{2}$. Radiative forcings at the alpine site tend to be lower because of lower dust concentrations and higher albedos, and corresponding daily mean RFs over the ablation season are $52 \mathrm{~W} / \mathrm{m}^{2}$ and $36 \mathrm{~W} / \mathrm{m}^{2}$ for extreme and lower dust years, respectively.

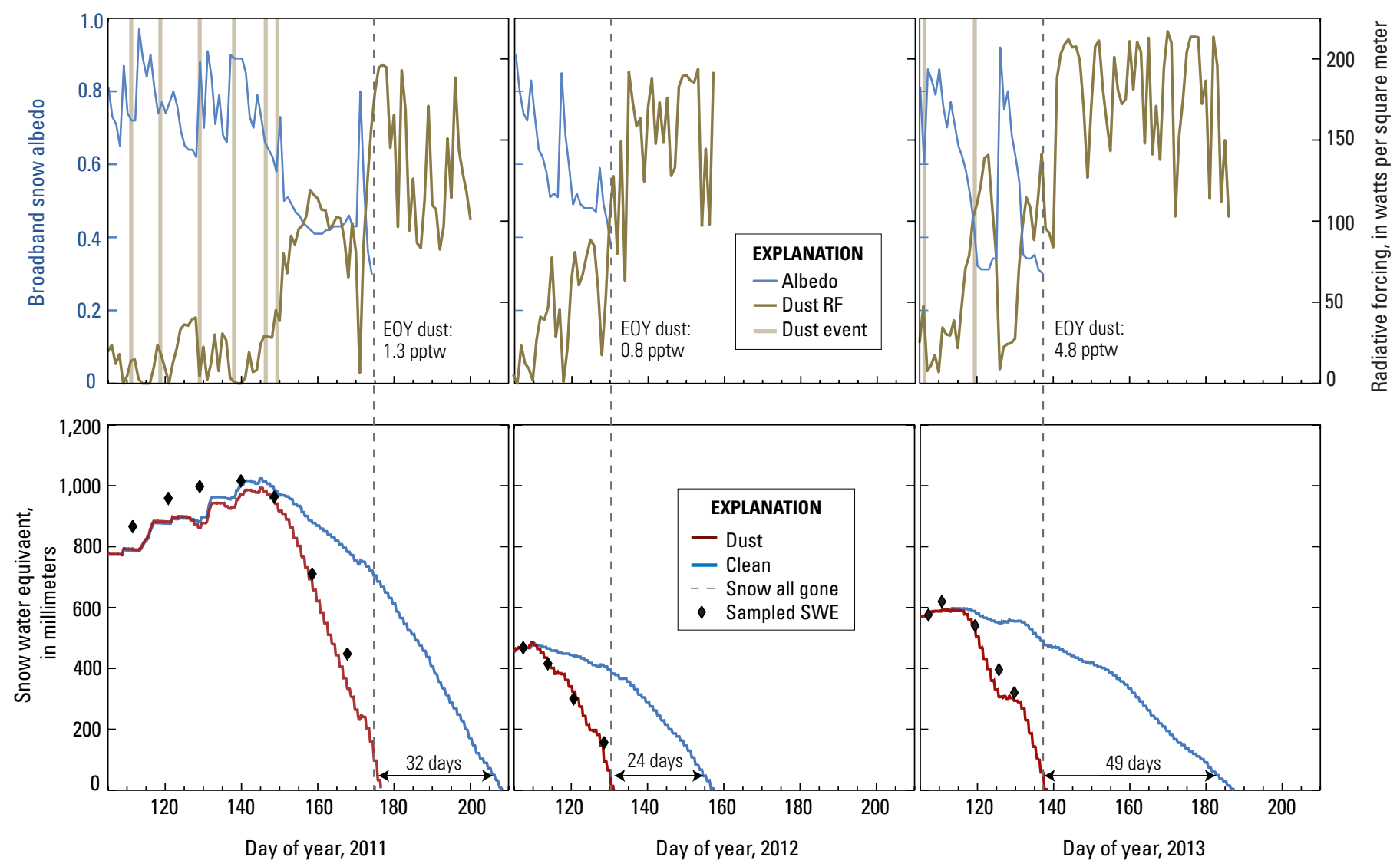

Figure 4. Graphs showing the evolution in snow albedo and dust radiative forcing (RF), from April 15th (day of year 105), along with dust event timing and end-of-year (EOY) dust concentration in parts per thousand by weight (pptw) for 2011-2013 (top panel), and the depletion of snow water equivalent (SWE) for the dust and clean scenarios (bottom panel). Measured SWE and observed snow all gone (SAG, dotted line) are plotted to show that the model is doing a good job of reconstructing observed conditions. 
Table 1. End-of-year dust concentrations $(\mathrm{mg} / \mathrm{g}$, milligrams per gram), ablation season daily mean radiative forcing $\left(\mathrm{W} / \mathrm{m}^{2}\right.$, watts per meter squared), and $\triangle S A G$ at the subalpine/alpine study plots in Senator Beck Basin Study Area in the San Juan Mountains of southwestern Colorado (the number of days difference between snow all gone dates for dust and clean scenarios).

\begin{tabular}{cccc}
\hline $\begin{array}{c}\text { Water } \\
\text { year }\end{array}$ & $\begin{array}{c}\text { EOY dust } \\
\text { concentration } \\
(\mathbf{m g} / \mathbf{g})\end{array}$ & $\begin{array}{c}\text { Daily mean dust } \\
\text { radiative forcing } \\
\mathbf{( W / m )}\end{array}$ & $\begin{array}{c}\Delta \text { SAG } \\
\text { (days) }\end{array}$ \\
\hline 2005 & $0.23 / 0.29$ & $45 / 27$ & $28 / 23$ \\
2006 & $0.98 / 0.89$ & $56 / 45$ & $31 / 21$ \\
2007 & $0.85 / 0.87$ & $45 / 38$ & $35 / 27$ \\
2008 & $0.86 / 0.53$ & $54 / 38$ & $27 / 26$ \\
2009 & $4.58 / 3.86$ & $75 / 50$ & $51 / 44$ \\
2010 & $4.34 / 2.67$ & $58 / 50$ & $48 / 37$ \\
2011 & $1.30 / 1.08$ & $50 / 32$ & $32 / 28$ \\
2012 & $0.82 / 0.54$ & $53 / 34$ & $24 / 27$ \\
2013 & $4.76 /$ not collected & $64 / 57$ & $49 / 38$ \\
\hline
\end{tabular}

The time period between dust SAG and clean SAG is the number of days when there would still be snow cover in the absence of radiative forcing by dust (fig. 4). These values provide a measure of how much additional solar radiation the ground is absorbing owing to earlier reduction of snowcovered area by dust radiative forcing. The RF varies over this period from $173 \mathrm{~W} / \mathrm{m}^{2}$ (2013) to $127 \mathrm{~W} / \mathrm{m}^{2}$ (2009), with an average of $151 \mathrm{~W} / \mathrm{m}^{2}$ at the subalpine site, and from $166 \mathrm{~W} / \mathrm{m}^{2}(2013)$ to $115 \mathrm{~W} / \mathrm{m}^{2}$ (2009) with an average of $148 \mathrm{~W} / \mathrm{m}^{2}$ at the alpine site. The lowest RF values occur in 2009 , despite being highest over the ablation season, because frequent cloud cover lowered total irradiance and therefore radiative forcing.

Mean daily radiative forcing from April 15 to clean scenario SAG provides an encompassing measure of dustforced snow-albedo feedbacks, including reduced albedo, enhanced grain growth, and earlier removal of snow cover. The daily mean RF over this period is again highest in extreme dust years with $113 \mathrm{~W} / \mathrm{m}^{2}$ and $91 \mathrm{~W} / \mathrm{m}^{2}$ at the subalpine and alpine site, respectively. In a lower dust year, mean daily RF was $86 \mathrm{~W} / \mathrm{m}^{2}$ and $71 \mathrm{~W} / \mathrm{m}^{2}$ at the subalpine and alpine site, respectively. In all years of the record, there is an additional $30-60 \mathrm{~W} / \mathrm{m}^{2}$ of radiative forcing for the period of April 15 to clean scenario SAG relative to dust scenario SAG; this contribution comes from earlier reduction in snow-covered area owing to dust radiative forcing.

\section{Advanced Snow Melt}

The additional energy from dust radiative forcing results in earlier snowmelt. Without direct observation of zero-dust conditions, the modeled clean snow scenario represents the best understanding of the evolution of the snowpack in the absence of dust. As discussed in the Methods section, the clean snowpack is modeled by removing the minimum and maximum RF attributed to dust, then averaging the daily values of these two scenarios to represent a conservatively clean snowpack. Because there is dust deposition in every year, the dust scenario always melts out earlier than the clean scenario. The difference, in numbers of days, between when the dust and clean scenarios reach $\mathrm{SAG}$ is referred to as $\triangle \mathrm{SAG}$.

As might be expected, the greatest degree of dustadvanced melt takes place in the extreme dust years with $\Delta$ SAG values of 51 (2009), 48 (2010), and 49 (2013) days at the subalpine site, respectively. The $\triangle \mathrm{SAG}$ at the alpine site is on average 6 days less, owing to the lower dust concentrations and RF values (44, 37, and 38 days for 2009, 2010, and 2013, respectively). The average of both sites gives an idea of the basinwide $\triangle \mathrm{SAG}$, which would be 44 days for extreme dust years. The lower dust years, 2005-2008 and 2011-2012, exhibit advanced melt on the scale of about a month: 24-34 days at the subalpine site and 23-28 days at the alpine site, with a basin wide $\triangle \mathrm{SAG}$ of 27 days (table 1). 
Radiative forcing by dust varies on multiple temporal scales, and the degree to which dust RF advances snowmelt can be influenced by factors such as the amount of SWE at the beginning of the ablation season (Painter and others, 2007) and the amount of new snowfall in the spring (Skiles and others, 2012). These factors do not influence the relationship between $\triangle \mathrm{SAG}$ and end-of-year dust concentrations exhibited at each site over the 9-year record, which is linear (fig. $5 ; \mathrm{R}^{2}$ value 0.93 , both sites). It should be noted that the relationship between reductions in snow albedo and increases in dust concentration is log-linear (Warren and Wiscombe, 1980), and given this, a nonlinear relationship between $\triangle \mathrm{SAG}$ and dust concentration would be expected as well. A longer data record from the SBBSA will allow us to better examine this relationship with additional data points to more fully populate the plot.

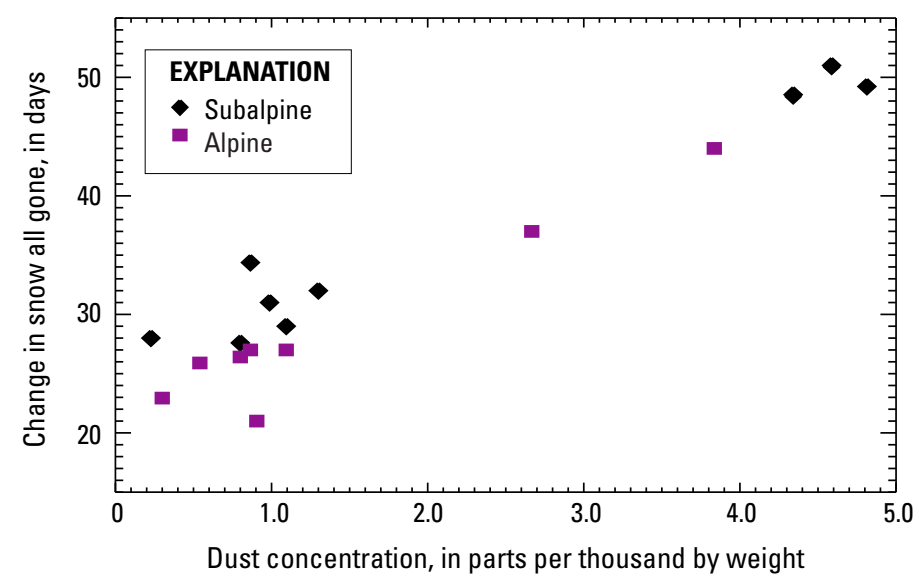

Figure 5. Graph showing the relationship between end-of-year dust concentration in parts per thousand by weight (equivalent to $\mathrm{mg} / \mathrm{g}$ ) and change in snow all gone date, or $\triangle \mathrm{SAG}$ (the number of days that dust advances melt) from 2005-2013 at Senator Beck Basin in the San Juan Mountains of southwestern Colorado.

\section{References Cited}

Bryant, A.C., Painter, T.H., Deems, J.S., and Bender, S.M., 2013, Impact of dust radiative forcing in snow on accuracy of operational runoff prediction in the Upper Colorado River Basin: Geophysical Research Letters, v. 40, no. 15, p. 3945-3949. [Also available at http://dx.doi.org/10.1002/ grl.50773.]

Conway, H., Gades, A., and Raymond, C.F., 1996, Albedo of dirty snow during conditions of melt: Water Resources Research, v. 32, no. 6, p. 1713-1718. [Also available at http://dx.doi.org/10.1029/96WR00712.]

Doherty, S.J., Grenfell, T.C., Forsström, S., Hegg, D.L., Brandt, R.E., and Warren, S.G., 2013, Observed vertical redistribution of black carbon and other insoluble light-absorbing particles in melting snow: Journal of Geophysical Research, v. 118, no. 11, p. 5553-5569. [Also available at http://dx.doi.org/10.1002/jgrd.50235.]

Landry, C.C., Buck, K.A., Raleigh, M.S., and Clark, M.P., 2014, Mountain system monitoring at Senator Beck Basin, San Juan Mountains, Colorado-A new integrative data source to develop and evaluate models of snow and hydrologic processes: Water Resources Research, v. 50, no. 2, p. 1773-1788. [Also available at http://dx.doi. org/10.1002/2013WR013711.]

Lawrence, C.R., Painter, T.H., Landry, C.C., and Neff, J.C., 2010, Contemporary geochemical composition and flux of aeolian dust to the San Juan Mountains, Colorado, United States: Journal of Geophysical Research, v. 115, no. G03007. [Also available at http://dx.doi. org/10.1029/2009JG001077.]

Li, J., Okin, G.S., Skiles, S.M., and Painter, T.H., 2013, Relating variation of dust on snow to bare soil dynamics in the western United States: Environmental Research Letters, v. 8 , no. 4, p. 1-8. [Also available at http:// dx.doi.org/10.1088/1748-9326/8/4/044054.]

Marks, D., and Dozier, J., 1992, Climate and energy exchange at the snow surface in the alpine region of the Sierra Nevada-2, Snow cover energy balance: Water Resources Research, v. 28, no. 11, p. 3043-3054. [Also available at http://dx.doi.org/10.1029/92WR01483.]

Marks, D., Kimball, J., Tingey, D., and Link, T., 1998, The sensitivity of snowmelt processes to climate conditions and forest cover during rain-on-snow-a case study of the 1996 Pacific Northwest flood: Hydrological Processes, v. 12, no. 10-11, p. 15691587. [Also available at http://dx.doi.org/10.1002/ (SICI)1099-1085(199808/09)12:10/11<1569::AIDHYP682>3.0.CO;2-L.] 
Neff, J.C., Ballantyne, A.P., Farmer, G.L., Mahowald, N.M., Conroy, J.L., Landry, C.C., Overpeck, J.T., Painter, T.H., Lawrence, C.R., and Reynolds, R.L., 2008, Increasing eolian dust deposition in the western United States linked to human activity: Nature Geoscience, v. 1, p. 189-195. [Also available at http://dx.doi.org/10.1038/ngeo133.]

Painter, T.H., Barrett, A.P., Landry, C.C., Neff, J.C., Cassidy, M.P., Lawrence, C.R., McBride, K., and Farmer, G.L., 2007, Impact of disturbed desert soils on duration of mountain snow cover: Geophysical Research Letters, v. 34, no. 12, 6 p. [Also available at http://dx.doi. org/10.1029/2007GL030284.]

Painter, T.H., Deems, J.S., Belnap, J., Hamlet, A.F., Landry, C.C., and Udall, B., 2010, Response of Colorado River runoff to dust radiative forcing in snow: Proceedings of the National Academy of Sciences, v. 107, no. 40, p. 17125-17130. [Also available at http://www.pnas.org/ content/107/40/17125.]

Painter, T.H., Skiles, S.M., Deems, J.S., Bryant, A.C., and Landry, C.C., 2012, Dust radiative forcing in snow of the Upper Colorado River Basin-1, A 6 year record of energy balance, radiation, and dust concentrations: Water Resources Research, v. 48, no. W07521, 14 p. [Also available at http://dx.doi.org/10.1029/2012WR011985.]
Skiles, S.M., Painter, T.H., Deems, J.S., Bryant, A.C., and Landry, C.C., 2012, Dust radiative forcing in snow of the Upper Colorado River Basin--2. Interannual variability in radiative forcing and snowmelt rates: Water Resources Research, v. 48, no. W07522, 11 p. [Also available at http:// dx.doi.org/10.1029/2012WR011986.]

Warren, P.L., Reichhardt, K.L., Mouat, D.A., Brown, B.T., and Johnson, R.R., 1982, Vegetation of Grand Canyon National Park-technical report no. 9: Tucson, Ariz., Cooperative National Park Resources Studies Unit, University of Arizona and National Park Service, 140 p. [Also available at http://sdrsnet.srnr.arizona.edu/data/techreports/ TECHRPT09.pdf.]

Warren, S.G., and Wiscombe, W.J., 1980, A model for the spectral albedo of snow-II, Snow containing atmospheric aerosols: Journal of the Atmospheric Sciences, v. 37, no. 12 , p. 2734-2745. [Also available at http://dx.doi. org/10.1175/1520-0469(1980)037<2734:AMFTSA > 2.0 .CO;2.] 


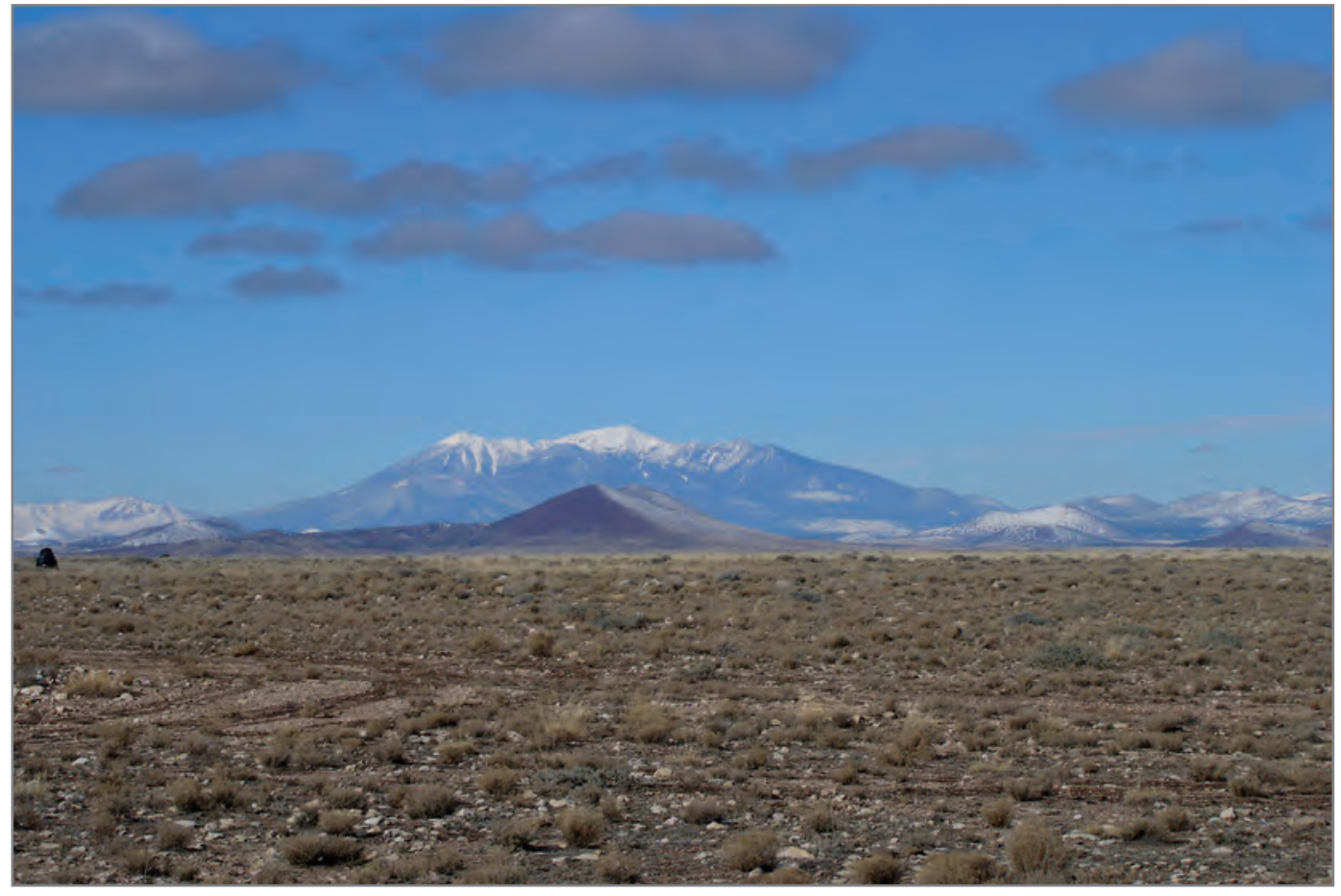

Looking west towards the San Francisco Peaks from near Leupp, Arizona. Photograph by Robert J. Hart, U.S. Geological Survey. 


\title{
Chapter C
}

\section{A Comparison of Historical and Future Rates of Climate Change in the Flagstaff Area of Northern Arizona}

\author{
By Kenneth L. Cole
}

\begin{abstract}
Climate observations from the Flagstaff region document a warming trend over the last 40 years of $0.041^{\circ} \mathrm{F}$ per year. A compilation of multiple General Circulation Models (GCMs) of the globe that were downscaled to focus on the southern Colorado Plateau projected a similar warming trend of $0.059^{\circ} \mathrm{F}$ per year to occur during this same period. If this warming were to continue linearly at its recent observed rate, Flagstaff's climate will be $4.9^{\circ} \mathrm{F}$ warmer by the $2090 \mathrm{~s}$. The GCMs applied here projected an accelerating rate that would result in a climate that is $7.2^{\circ} \mathrm{F}$ warmer by the 2090s. Annual precipitation in the Flagstaff area has declined about 11 percent over the last 20 years from the prior 70 -year period. This decline occurred during the cool-season period while the summer monsoon precipitation increased. These shifts in both total and seasonal precipitation mirror the results from suites of multiple GCMs applied to the same period. Future comparisons between observed trends and older GCM downscaled projections should become more valuable through time because they can illustrate the strengths and weaknesses of GCM modeling in projecting future climate trends. The strong agreement between observed climate trends and GCM projections of rising temperatures and decreasing precipitation for the Flagstaff area is a cause for concern about future ecological effects and water availability, although some ecological impacts could be mitigated by an increase in summer monsoon precipitation projected by a few GCMs.
\end{abstract}

${ }^{1}$ Northern Arizona University and 12 Pinyons Research Station

\section{Climate of the Flagstaff Area}

The climate of northern Arizona is distinct from that of the more populated desert areas surrounding Phoenix and Tucson. Unlike the hot desert areas of Arizona, the high-elevation plateaus north of the Mogollon Rim (fig. 1) support winter-cold forests that are mildly pleasant in summer (Staudenmaier and others, 2007). These high plateaus typically receive winter snowfall of 100 inches or more, and temperatures are rarely above $85^{\circ} \mathrm{F}$ in the summer.

Analyzing Arizona's climate using the traditional seasons found in Europe or eastern North America - winter, spring, summer, and fall — can be misleading. Northern Arizona has three discrete rainfall seasons and one extreme dry season, but they conform to a distinctive monthly sequence (Sellers and Hill, 1974; Sheppard and others, 2002; Steenburgh and others, 2013). Between late November and early April, Pacific cyclonic storm systems bring gentle rain across the area (fig. 2). This important period produces about two-thirds of 
the annual precipitation. These cool-season rains are crucial for groundwater recharge because they add high-elevation snowpack and snowfall while evaporation rates are low. However, the earliest of the cool-season precipitation (between November and December) falls while upper elevation plants are dormant, and it is not important for most middle to upper elevation plant species (Cole and others, 2008) or the animals dependent upon those plant species (van Riper and others, 2014). If these early season rains are not supplemented by later rains, the surface soils become desiccated by May when the upper elevation growing season finally begins.

These cyclonic storm events become less frequent by late March, and rarely occur after mid-April, leading to the second distinct season; the late-spring/early-summer dry months of May and June. This stressful drought period can have critical effects on plant and animal life (Breshears and others, 2005) because it occurs just when evapotranspiration is increasing owing to the increasing temperatures. By about mid-July, summer monsoon convective storms begin in the Flagstaff area (Liebmann and others, 2008) and moist, southerly air masses from the Gulf of California, the Gulf of Mexico, and sometimes the Pacific Ocean offshore of Baja California can lead to extreme monsoon high-precipitation events. This summer monsoon period extends from July through September, and by mid-September additional precipitation may occasionally be generated by tropical cyclonic storms (hurricanes, locally known as chubascos) off the west coast of Baja California. The moisture from these cyclonic storms can occasionally lead to high-precipitation events in this fourth season, typically between midSeptember and early November.

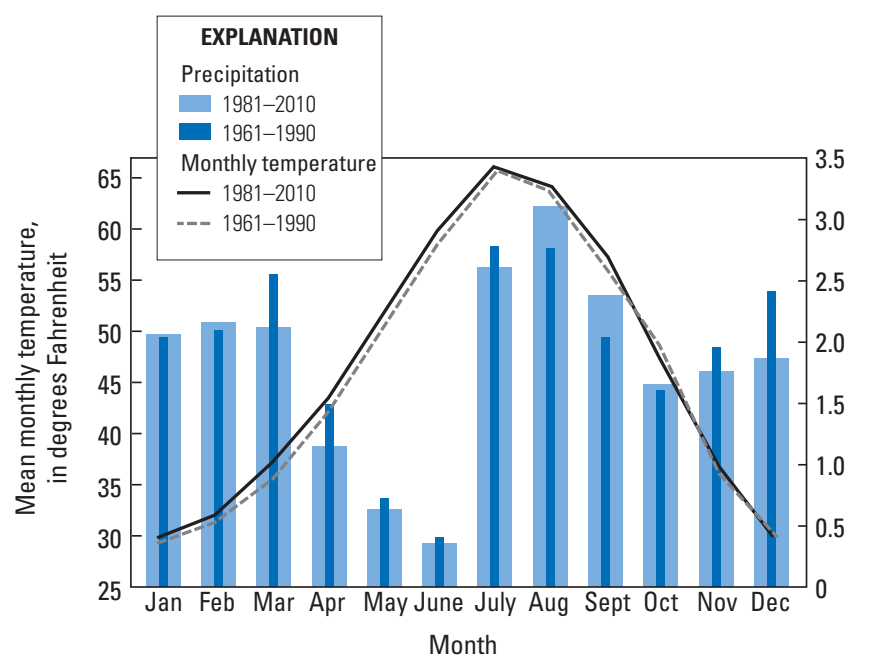

Figure 2. Climograms showing the monthly climates of Flagstaff measured at Flagstaff Pulliam Airport during two 30-year periods. Mean monthly precipitation is shown with wider light blue bars (1981-2010) and narrower dark blue bars (1961-1990). Mean monthly temperatures are shown with a black line (1981-2010) and a dashed gray line (1961-1990).

\section{Projections of Climate Change}

The scientific basis for climate changes caused by the increase of atmospheric carbon dioxide and other greenhouse gases has been understood for well over a century, whereas the confirmation of these ongoing changes in atmospheric composition have been accurately measured for over 60 years. The effects of these changes on the Earth's climate have been continually refined using computer-based General Circulation Models (GCMs) for about the past 40 years. But it was only within the last decade or two that the projections of these global models became detailed enough that their effects could be reasonably projected to specific regions. ${ }^{2}$

As regional GCMs climate projections increase in precision, they can be compared to station-based climate observations within individual regions. And, with an increasing number of years of recorded climate records since the onset of likely greenhouse-caused climate shifts (International Panel for Climate Change [IPCC], 2013), these comparisons increase every year in their statistical power. However, climate change is highly dynamic, and adjoining regions can be affected in opposite ways. So, changes in any one region, or even a subcontinent, will not prove or disprove that climate change is occurring, yet analyses of regional trends may be reaching the point of yielding predictive value for that region. This paper compares regional-scale GCM projections and ground-based measurements within the same region. This comparison is preliminary in nature, as GCMs are continually being improved, and observational records increase in detail every year. Yet this comparison for the Flagstaff area of northern Arizona shows surprising agreement for trends of temperature change, and it raises important concerns for trends in precipitation resources, which are crucial in this arid region.

A series of future climate projections completed prior to 2004 were compiled and published by Garfin and others (2010) using the Fourth Assessment Report (AR4) GCM data compilation with the A1B $\mathrm{CO}_{2}$ scenario (IPCC, 2007). These projections had been downscaled from the extremely large spatial grids ( $\sim 200$ miles by $\sim 200$ miles) produced by GCMs, to landscape grids of about 1.2 by 1.2 miles using a procedure known as statistical downscaling. ${ }^{3}$ This

${ }^{2}$ The first IPCC climate assessment report detailed GCM results based upon grid sizes of more than 300 miles ( $\sim 500 \mathrm{~km}, \mathrm{~T} 21)$ (IPCC, 1990). By the fourth assessment, some models were included using grid sizes of only 68 miles $(\sim 110 \mathrm{~km}, \mathrm{~T} 106)$ (IPCC, 2007).

${ }^{3}$ The following is a brief synopsis of downscaling procedures, as fully described by Garfin and others (2010). The GCMs were aligned to a common grid - the 4-km grid used by PRISM (Daly and others, 1994) - using inversedistance weighting (Eischeid and others, 2000). Next, they were statistically downscaled (Salathé, 2005) using the 1950 to 1999 PRISM estimates from each grid cell to impose spatial structure to the GCM-simulated monthly precipitation and temperature while preserving the atmospheric processes driving the simulations. Bias between the large-scale simulated climate parameter and 
downscaling procedure projects the changes from the large GCM grid to specific regional landscapes. It can be thought of as an elevation lapse-rate correction at each local grid cell relative to the larger GCM grid (Salathé, 2005). Although the method does not incorporate a few of the effects of the local topography on the region's climate such as rain shadows, the high correlation of temperature with elevation results in statistical downscaling that is very reliable for temperature variations in arid regions of high topographic diversity. In Arizona, temperatures are highly correlated with elevation (Smith, 1956) owing to the uniform physical properties of gases under varying pressures. Precipitation is also well correlated with elevation, but it can be a much more episodic and localized variable, and thus more difficult to model.

The data from Garfin and others (2010) can serve as a baseline prediction for comparison with subsequently monitored climates. An optimal test of scientific prediction versus subsequent results would require even earlier projections resulting in a longer subsequent test period. Unfortunately, these GCM results were the first such results with sufficient spatial detail to portray the southern Colorado Plateau as a specific region.

The GCM data applied in this paper from Garfin and others (2010) were a product of GCMs run between about 2001 and 2003 that were available from the 2005 AR4 compilation from the IPCC (2007). More recent and refined GCM data are now available through the Fifth Assessment Report (AR5) (IPCC, 2013), although the differences within the region are not great (Seager and others, 2012). The older data used in this report have the advantage of having been produced over a decade ago allowing them to be treated as forming testable hypotheses of future climate change. Also, there remains skepticism that they may have been adjusted to produce a reasonable output, ${ }^{4}$ although actual 20 th or 21 st century climate changes have not been entered into the models (IPCC, 2007, 2013). But, older regional GCM output could serve as a forceful scientific tool for testing their reliability since they could not possibly have been adjusted after their results were published.

the observed climate parameter at each grid cell was corrected by month. As a result, at each grid cell the average magnitude of the GCM historic period simulations conformed to the average 1950-1999 observation from that gridcell, as extrapolated from the PRISM dataset.

Spatial biases and magnitudes were corrected independently at each grid point for each model by multiplying the simulated parameters by a monthly bias factor (for precipitation) or by calculating the difference between the simulation and the bias factor (for temperature), as described with equations adapted from Salathé (2005). This additive method may be thought of as a lapse-rate correction owing to the elevation difference of the local gridpoint relative to the GCM grid (Salathé, 2005). No allowance is made for possible changes in the lapse rate as a consequence of climate change.

${ }^{4}$ The retired physicist, Freeman Dyson, is widely quoted as having stated in an interview "They [the global climate models] are full of fudge factors that are fitted to the existing climate, so the models more or less agree with the observed data" (Solomon, 2007). However, there are detailed published analyses that demonstrate their reliability including Risbey and others (2014) and Raisanen (2007).
These types of comparisons will become even more statistically reliable in the future as the subsequently measured climates increase in duration. In this way, a past synthesis of GCM data could become scientifically as valuable as newer refined GCM projections. They represent the most extreme test of science, prediction of future experimental results. Unfortunately this experiment is being run on our only planet.

The GCMs used here projected a warming trend on the southern Colorado Plateau starting about 1975 and extending into the future. The vast majority of both the models used in this paper (Seager and others, 2007) and the next generation of models (Seager and others, 2012) project a trend of decreasing annual precipitation in the arid southwest throughout the 21 st century, although individual models differ greatly in their projections of the monsoon precipitation (see Comparing Precipitation Trends section). These combined trends of higher temperatures, coupled with decreasing rainfall, can be highly detrimental to the flora and fauna (Allen and others, 2010).

This paper is focused on the following questions: (1) Is this warming trend projected from the GCMs evident in the recent recordings from regional climate stations? and (2) If so, how do the recent rates of change compare to those projected into the future? Most analyses of this type apply large complex datasets from many climate stations across multi-state regions. However, in this study three long-term stations in the homogeneous climate area close to Flagstaff are analyzed, minimizing the irregularities that often can be overlooked when compiling large datasets. ${ }^{5}$

\section{Historical Climate Records from the Greater Flagstaff Area}

Historical records contain the most accurate climate data in both the precision of measurements and the size of their represented area. Here, a review of the recent trends in northern Arizona's local climate data is provided prior to a comparison with climate model projections, which are inherently more general in scope.

I averaged the records from three stations in a local area because of the variability inherent even in adjacent climate stations for monsoon precipitation (table 2). Three

\footnotetext{
${ }^{5}$ Large data compilations require uniform data across hundreds of individual climate stations even though close examination might reveal instances where some individual station data are inappropriate. For example, Garfin and others (2013), in order to apply uniformity to a vastly larger data set encompassing six States, examined rates of climate warming between the years 1901 and 2000. However, prior to 1909 the most reliable station in the Flagstaff area, Williams (used by Garfin and others to represent the area), contained more months without data than recorded months. Additionally, until 1940 Williams recorded anomalously low temperatures compared to the other two stations analyzed here (fig. 2). This paper takes an intermediate approach, closely examining each individual station record, yet averaging the data from three closely spaced stations to reduce variability.
} 
long-term climate stations in the Flagstaff area-Williams, Flagstaff Pulliam Airport, and the Fort Valley Experimental Station ${ }^{6}$ - are all located within 30 miles $(50 \mathrm{~km})$ of each other, and at relatively similar elevations when compared to other stations in the region. These three stations have longer records than many others in the arid southwest and are not adjacent to intense urban development that could potentially generate urban heat. The three stations differ somewhat in climate primarily because of their minor differences in elevation, ranging from 6,750 feet $(2,057 \mathrm{~m})$ at Williams, to 7,010 feet $(2,137 \mathrm{~m})$ at Flagstaff, and to 7,360 feet $(2,243 \mathrm{~m})$ at Fort Valley.

Although some measurements at these stations began as early as 1894 (Flagstaff), 1897 (Williams), and 1909 (Fort Valley), these early instruments were moved frequently and had many missing months until about 1924, when all three records became fairly continuous. ${ }^{6,7}$ Several other climate stations in northern Arizona were not used in this analysis owing to their shorter records and the effects of complex topography on precipitation. For example, climate stations at Sunset Crater (recorded since 1969 at 6,980 feet elevation) and Wupatki National Monument (recorded since 1940 at 4,900 feet elevation) detail significant records. But these are farther from the other stations, have much shorter records, and are located northeast of the central Arizona Divide and San Francisco Peaks. These stations, and other stations farther to the north (for example, Cameron and Lees Ferry), record much lower cool-season precipitation values than stations to their west likely owing to their position in the rain shadow of the higher elevations of north-central Arizona.

The data analyzed here were obtained from the Western Regional Climate Center (2013), and the National Oceanic and Atmospheric Administration (2014). Summaries of climate records for the Flagstaff station can be found in Staudenmaier and others (2007).

${ }^{6}$ Station metadata

\begin{tabular}{lccl}
\hline \multicolumn{1}{c}{ Station } & $\begin{array}{c}\text { Coop } \\
\text { number }\end{array}$ & $\begin{array}{c}\text { Elevation, } \\
\text { (feet) }\end{array}$ & $\begin{array}{c}\text { Years with at least 10 months } \\
\text { temperature data }\end{array}$ \\
\hline Williams & $029359-2$ & 6,750 & $\begin{array}{l}1987,1904,1905,1912,1916- \\
1946,1948-1957,1959-2014\end{array}$ \\
& & & $\begin{array}{l}1894-1895,1897,1924-1940, \\
1950-2014\end{array}$ \\
Flagstaff & $023010-2$ & 7,010 & \\
Fort Valley & $023160-2$ & 7,360 & $\begin{array}{l}1909-1993,1994-2000,2004- \\
2013,2014 \text { (temperature only) }\end{array}$ \\
\hline
\end{tabular}

${ }^{7}$ Some missing monthly temperature values from one of the three stations still had to be estimated using Period of Record correlations from the other two stations for 119 months (out of 3,240 possible) since 1924, including 6 missing years from Flagstaff data during the 1940s. All monthly index values contained observed data from at least two of the three stations.

\section{Temperature Trends}

Climate changes can be studied statistically in different ways, usually as continuous trends through time, or as step changes between different periods of multiple years. With either approach, there can be disagreements over the selection of the specific beginning and end dates for each period. For example, because 1998 was the warmest year ever recorded up to that point globally, selecting a period starting in 1998 generated a trend that showed little subsequent warming (Silver, 2013). This began a period that has been referred to as the climate warming "hiatus" (Kaufmann and others, 2011; Karl and others, 2015). However, three ensuing years $(2005,2010$, and 2014) have subsequently been recorded as even warmer than 1998 (National Oceanic and Atmospheric Administration, 2015). Statistically, the year-to-year variability in measurements is far too great to infer significance from a single year or even a few years. For this reason, climatologists typically represent climates as averages of 30 years, as shown in figure 1 . But if climate has been more rapidly changing over just the last 10 or 20 years, as inferred by GCMs and the atmospheric concentrations of carbon dioxide, then this 30-year period would not fairly represent trends that might be apparent on a shorter time period. As a result, this study illustrates trends in 10-year (decadal) averages, but will only statistically compare different periods of 20 years or more. ${ }^{8}$

The average temperatures recorded each year from three stations in the local Flagstaff area from 1924 through 2013 are shown on figure 2 . The considerable differences between the stations are due to their different elevations and other landscape factors. Over the entire period, temperatures in Williams averaged $3.25^{\circ} \mathrm{F}$ warmer than Flagstaff, and temperatures at Fort Valley averaged $2.97^{\circ} \mathrm{F}$ cooler. Despite these differences, all three stations show similar decadal trends to the regional decadal trend throughout the period. ${ }^{9}$ The trends are especially similar since 1950 as the current station locations were fixed and the readings became more consistent and reliable. The Flagstaff station shows values very similar to the regional trend as it is located at mid-elevation between the other two stations.

Determining rates of any temperature changes through time requires critical decisions on the length of the time period studied. Because of the high year-to-year variability (black points on figure 3 ), accuracy is lost when analyzing any period of less than 20 years. But, applying too long a time period, such as the last century, does not

\footnotetext{
${ }^{8}$ The high year-to-year variability of climate (figs. 2,3 ) causes parametric statistical tests comparing groups of values fewer than 20 to be far less effective. Thus, for annual values, 20 years is a practical compromise between the 30 years typically used by climatologists and shorter periods with less statistical power. Moving averages of 10 years are shown on figures 3, 4, and 5 for illustrative purposes but are not analyzed statistically.

${ }^{9}$ This illustrates the general feature that regional temperatures are a much more robust variable when compared to sporadic local rainfall records. A cold day in Flagstaff is often a cold day in Phoenix. But rainfall records are far less predictable. Rainfall in Flagstaff may or may not indicate rainfall in Phoenix, or even as nearby as Williams.
} 
account for the escalation in atmospheric $\mathrm{CO}_{2}$ starting around the years 1960 to 1970 (fig. 5; IPCC, 2007). Atmospheric $\mathrm{CO}_{2}$ only increased from about 297 parts per million (ppm) to $326 \mathrm{ppm}$ in the 70 years between 1900 and 1970 (about 0.1 percent per year). In contrast, it increased nearly five times as fast from $326 \mathrm{ppm}$ to $398 \mathrm{ppm}$ between 1970 and the end of 2013 (about 0.5 percent per year), making this time period the most important for study of any relation between atmospheric $\mathrm{CO}_{2}$ levels and climate. Examining periods of several different lengths is preferable to selecting any particular period during this interval.

Table 1 shows the mean annual temperatures for the first 70 years of records (1924-1993) and the most recent 20 years (1995-2014). Although the difference between the periods is only $+1.5^{\circ} \mathrm{F}$, it is a statistically significant shift. The rate of this temperature increase can be extrapolated by fitting linear regressions through the last 20,30, or 40 years producing warming rates of $0.021^{\circ} \mathrm{F} /$ year $\left(\mathrm{r}^{2}=0.01, \rho=0.79\right)$, $0.044^{\circ} \mathrm{F} /$ year $\left(\mathrm{r}^{2}=0.13, \rho=0.48\right)$, and $0.041^{\circ} \mathrm{F} /$ year $\left(\mathrm{r}^{2}=0.18\right.$, $\rho=0.01)$. The similarity of these longer rates suggests that this increase has been a fairly steady rate of increase, rather than a step-change within any part of the period. The lower rate calculated over the last 20 years could suggest a reduction in the rate of warming (Risbey and others, 2014; Raisanen, 2007), although 20 years does not appear to be a sufficient statistical sample for a measure of such high variability as shown on figure 3 . Note that the warmest 2 years for this index for the Flagstaff area were 2003 and 2014. Analysis of this average temperature-warming trend suggests that it is primarily driven by higher nighttime temperatures, especially from October through May (Hereford, 2007).

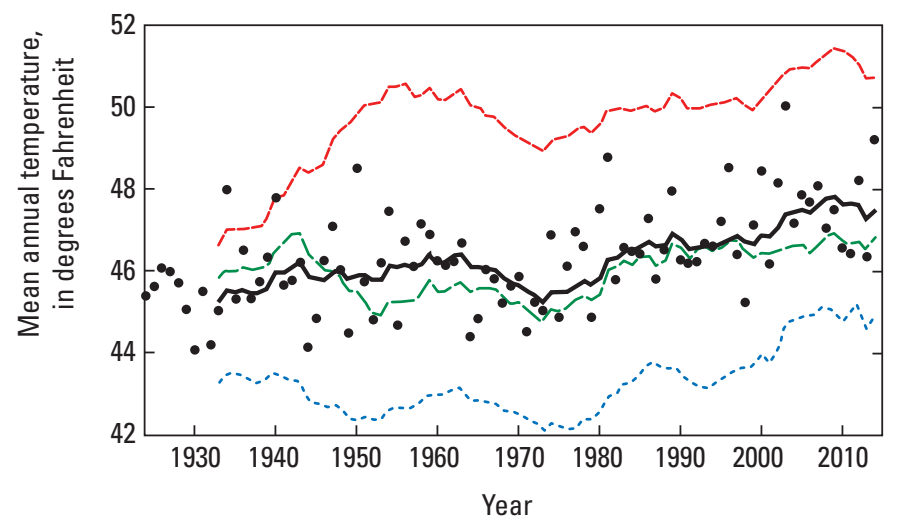

Figure 3. Plot showing the decadal moving averages for mean annual temperatures from 1924 to 2014 . Black line is regional temperature index (an average of all three stations) and average yearly values are shown as black dots. Decadal trends from individual stations are Williams (red), Flagstaff (green), and Fort Valley (blue).
Table 1. Mean annual temperatures measured during selected periods.

[ft, feet; ${ }^{\circ} \mathrm{F}$, degrees Fahrenheit]

\begin{tabular}{ccccc}
\hline \multirow{2}{*}{$\begin{array}{c}\text { Time } \\
\text { period }\end{array}$} & \multicolumn{3}{c}{$\begin{array}{c}\text { Climate station mean annual } \\
\text { temperature }\left({ }^{\circ} \mathbf{F}\right)\end{array}$} & $\begin{array}{c}\text { Regional index } \\
\text { Rem }\end{array}$ \\
\cline { 2 - 5 } & $\begin{array}{c}\text { Williams } \\
\text { mean annual }\end{array}$ & $\begin{array}{c}\text { Flagstaff } \\
(\mathbf{6 , 7 5 0} \mathbf{f t})\end{array}$ & $\begin{array}{c}\text { Fort Valley } \\
(\mathbf{7}, 360 \mathrm{ft})\end{array}$ & $\begin{array}{c}\mathbf{( 2 , 1 3 7} \mathbf{f t}) \\
\text { temperature }\left({ }^{\circ} \mathbf{F}\right)\end{array}$ \\
\hline $1924-1993$ & $49.2 \pm 1.6$ & $45.9 \pm 1.3$ & $42.9 \pm 1.7$ & $246.0 \pm 1.0$ \\
$1995-2014$ & $50.8 \pm 1.0$ & $46.7 \pm 1.1$ & $44.8 \pm 2.0$ & $247.5 \pm 1.1$ \\
\hline
\end{tabular}

${ }^{1}$ Average of all three stations.

${ }^{2}$ Student's t-test shows the 1924-1993 and 1995-2014 averages are statistically different $(\mathrm{P}=<0.001)$.

\section{Precipitation Trends}

The average precipitation amounts recorded for the Flagstaff region from 1924 through 2014 are shown in figure 4 and table 2. Although all three stations together averaged 20.8 inches for the period, averages for individual years were as high as 37.9 inches (1965) and as low as 11.7 inches (1956), demonstrating the high variability in annual rainfall even when averaged over the entire year and multiple stations. Precipitation was even more variable among stations, especially for late summer (July through September) monsoon precipitation. Monsoon precipitation has been particularly high in recent years, including 2014 (third highest) and 2013 (seventh highest). Average monsoon precipitation at all three stations did not show a significant difference between the first 70 years (1924-1993) and the most recent 20 years (1995-2014), but the variability was too high to reject the conclusion that a change has occurred (fig. 4; table 2). Individual stations record the high spatial variability of this rainfall, even when averaged across 3-month periods. For example, in the 2009 monsoon period, Williams received over twice the total precipitation of Flagstaff, whereas in 2013, Flagstaff received over twice the amount measured at Fort Valley (table 2).

The annual precipitation averaged at all three stations was less for the most recent 20 years (1995-2014), than for the first 70 years (1924-1993) (table 2; $\mathrm{P}=0.059$; significant to the 94.1 percent level versus the 95.0 percent level that is usually considered to be statistically significant). This step-like change in annual amount of 2.4 inches (11 percent), as shown by the decadal moving average (fig. 4), seemed to start in the mid-1990s. Most of this change appears to have been caused by a decrease in the cool-season cyclonic storms that characterize much of the rainfall between late November and April. At least half of this decrease is evident in the statistically significant decrease in March through June precipitation (fig. 4; table 2). March through June is shown here rather than just the most extreme late-spring/earlysummer drought months of May and June because these two months have always had negligible precipitation. A further reduction in rainfall from something that was very little 
is probably not as relevant as the fact that this dry season period now seems to be lengthening by starting earlier in March and April. For ecosystems dependent on stored soil moisture, abundant precipitation in March and April can offset a dry May and June, or even a dry November through February. Available soil moisture at the start of the growing season is of crucial importance (Breshears and others, 2005); the specific month supplying that moisture is of less importance.

A warm and dry 4-month period can increase plant mortality as well as fire severity (McDowell and others, 2009; Westerling and Swetnam, 2003). The combination of decreasing March through June precipitation and higher temperatures is most crucial for sustaining ecosystems (Breshears and others, 2005). These higher temperatures increase soil evaporation and plant evapotranspiration further compounding the decreasing moisture and increasing the soil moisture deficit.

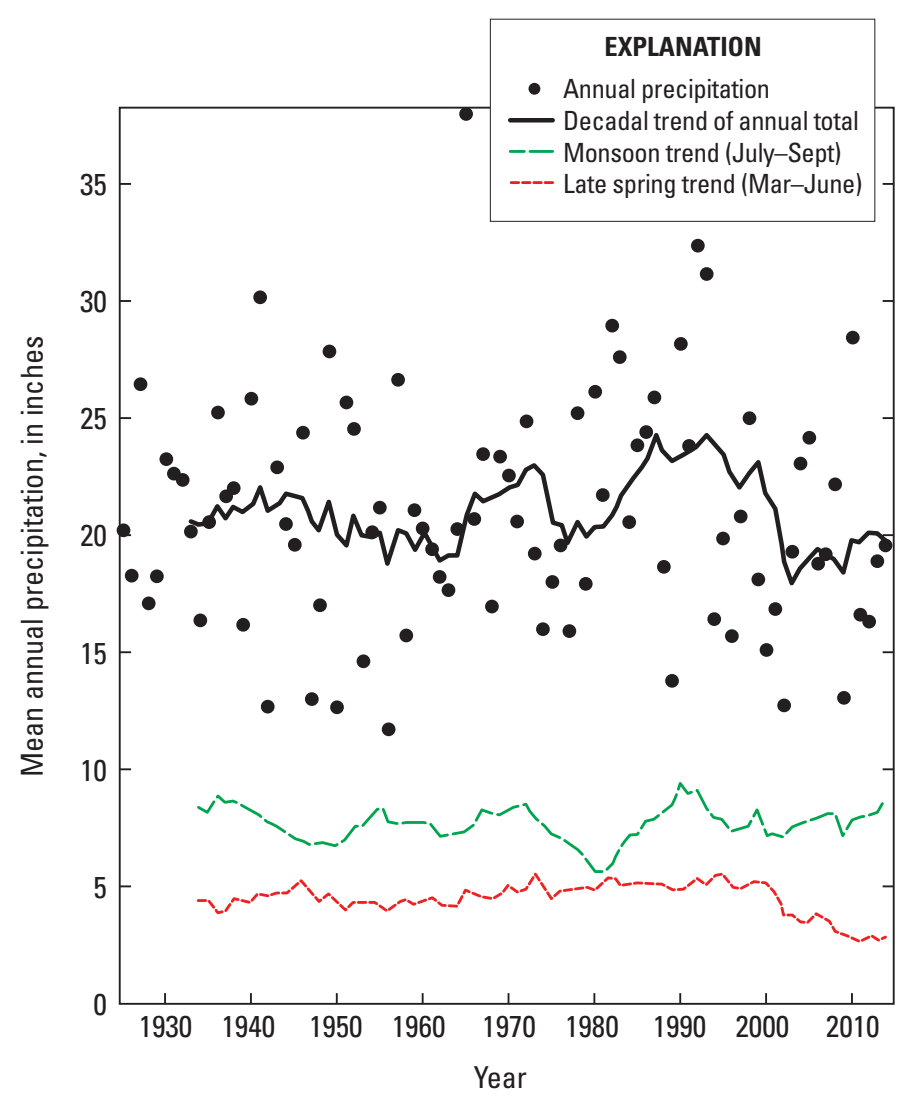

Figure 4. Plot showing the decadal moving mean of annual precipitation for 1925-2014. Black line is regional precipitation index (an average of Williams, Flagstaff, and Fort Valley stations). Average yearly values are black dots. Most annual precipitation (58 percent) falls from October through April. But important seasonal trends are the summer monsoon (July through September, green line), and the late-spring/early-summer (March through June, red line).
Table 2. Annual and seasonal precipitation measured during selected periods.

[ft, feet]

\begin{tabular}{|c|c|c|c|c|}
\hline \multirow[b]{2}{*}{ Time period } & \multicolumn{3}{|c|}{ Climate station precipitation (inches) } & \multirow{2}{*}{$\begin{array}{c}\text { Regional } \\
\text { index } \\
\text { precipitation } \\
\text { (inches) }\end{array}$} \\
\hline & $\begin{array}{l}\text { Williams } \\
(6,750 \mathrm{ft})\end{array}$ & $\begin{array}{l}\text { Flagstaff } \\
(7,360 \mathrm{ft})\end{array}$ & $\begin{array}{c}\text { Fort Valley } \\
(2,137 \mathrm{ft})\end{array}$ & \\
\hline \multicolumn{5}{|c|}{ Mean annual total } \\
\hline $1924-1993$ & $20.9 \pm 5.9$ & $20.9 \pm 5.9$ & $22.4 \pm 5.0$ & ${ }^{2} 21.4 \pm 5.0$ \\
\hline 1995-2014 & $19.7 \pm 5.4$ & $18.6 \pm 4.9$ & $19.0 \pm 4.4$ & ${ }^{2} 19.1 \pm 4.1$ \\
\hline \multicolumn{5}{|c|}{ Mean March through June total } \\
\hline $1924-1993$ & $4.4 \pm 2.2$ & $4.6 \pm 2.1$ & $5.1 \pm 2.1$ & ${ }^{3} 4.7 \pm 2.0$ \\
\hline 1995-2014 & $3.2 \pm 2.1$ & $3.0 \pm 1.8$ & $3.1 \pm 1.9$ & ${ }^{3} 3.1 \pm 1.7$ \\
\hline \multicolumn{5}{|c|}{ Mean monsoon total (July through September) } \\
\hline $1924-1993$ & $7.6 \pm 2.9$ & $7.2 \pm 2.7$ & $8.2 \pm 2.7$ & $7.7 \pm 2.3$ \\
\hline 1995-2014 & $8.4 \pm 3.0$ & $8.0 \pm 3.2$ & $7.8 \pm 3.3$ & ${ }^{4} 8.2 \pm 2.6$ \\
\hline \multicolumn{5}{|c|}{ Monsoon total (July through September) } \\
\hline 2009 & 5.4 & 2.5 & 3.9 & 3.9 \\
\hline 2013 & 11.3 & 15.7 & 7.1 & 11.4 \\
\hline
\end{tabular}

${ }^{1}$ Average of all three stations.

${ }^{2}$ Student's t-test shows these totals are very close to statistically different $(\mathrm{P}=0.059)$.

${ }^{3}$ Mann-Whitney rank-sum test shows these totals are statistically different $(\mathrm{P}=0.005)$, but the data are too variable to apply the t-test.

${ }^{4}$ Student's t-test shows these totals are not statistically different $(\mathrm{P}=0.63)$, but low power indicates it is less likely to detect a difference when one exists.

\section{Climate Model Projections for 1924 to 2099}

The GCM data applied in this paper are just a small part of the results described in Garfin and others (2010). They projected monthly temperatures and precipitation for the continental United States west of Kansas (west of long $110^{\circ} \mathrm{W}$.) to every 1.2 by 1.2 mile grid point (about 800,000 grid squares) for every year between 1900 and $2099(2,400$ sequential monthly values). Furthermore, they compared results from 5 individual simulations, each produced by different GCMs, and 1 data compilation (or ensemble) that averaged 48 simulations from 22 different GCMs.

All five of the GCMs compared in the Garfin and others (2010) study produced similar future projections of mean annual temperature, although each model varied around a central trend similar to annual variations found in an actual climate record. Earth's climate varies from year to year because of random factors and complex influences from prior years. The ensemble data, averaging the results from 48 simulations from 22 different GCMs, is more useful for 
comparison with observed temperature trends because individual GCM year-to-year variability has been removed by combining multiple runs of multiple models. Because every year in this ensemble dataset is essentially an average of 48 different modeled years, it doesn't show the yearto-year variation that characterizes either the results of years portrayed by a single model, or years of real climate. These annual averages were further averaged into a weighted average of multiple years to emphasize the underlying trends. As a result, the past and future projected temperature trends shown in figure 5 are generalized trends, not unlike the Earth's climate would produce if somehow decades of history could be re-run 48 times.

Although these GCM averages are the product of non-linear models producing a different value every year, linear regressions can still be fit to their yearly projections. This results in rates of increase of $0.059^{\circ} \mathrm{F} /$ year for the most recent 40 years, $0.070^{\circ} \mathrm{F} /$ year through 2050 , and $0.070^{\circ} \mathrm{F} /$ year through 2099 .

\section{Comparing Warming Rates}

Over the last 20 years (1995 through 2014), temperatures in the Flagstaff area averaged $1.7^{\circ} \mathrm{F}$ higher than the 1924-1973 50-year baseline (table 3). The GCMs modeled the same amount of increase during this period.

Future temperatures in table 3 are estimated using a linear continuation of recent trends as well as using GCM projections. The linear extrapolation does not incorporate the highly complex nonlinear atmospheric and oceanic processes or environmental feedbacks that are incorporated into the GCM

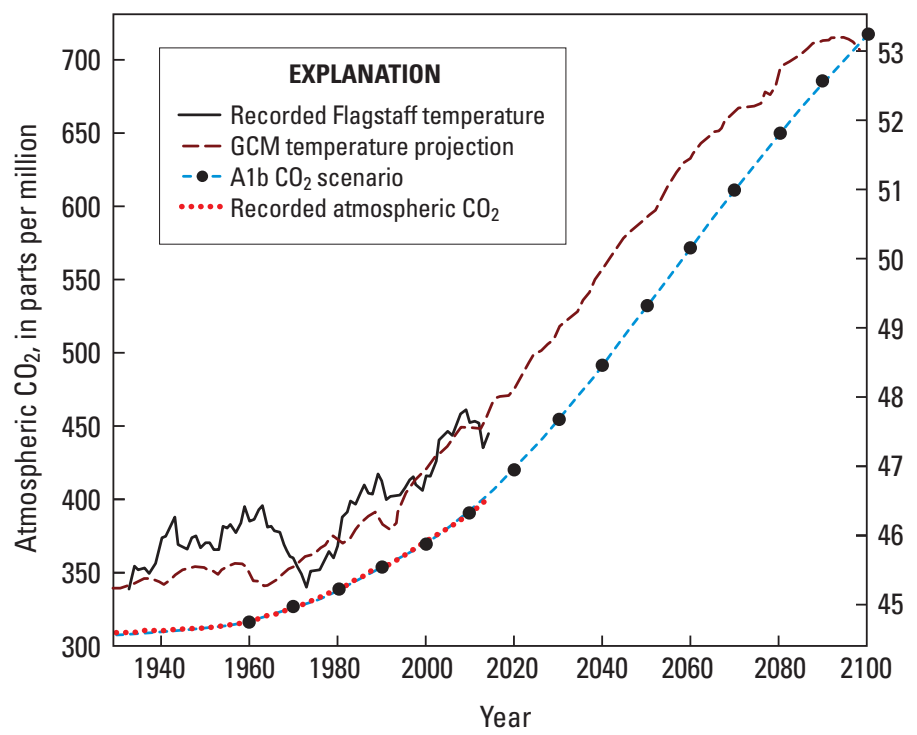

Figure 5. Plot of measured and modeled mean annual temperature and $\mathrm{CO}_{2}$. The regional index of historical measured temperatures (black line) is contrasted with the GCM model projections (brown dashed line) for the southern Colorado Plateau for the time period 1924-2099 (modified from Garfin, 2007). Both trends are 10 year running averages. Measured atmospheric $\mathrm{CO}_{2}$ in parts per million (red dotted line) from the Scripps $\mathrm{CO}_{2}$ Program (2013) is contrasted with the $\mathrm{A} 1 \mathrm{~B} \mathrm{CO} \mathrm{C}_{2}$ scenario (black dots and cyan dashed line) (IPCC, 2007).

Table 3. Historical mean annual temperatures of the Flagstaff area and estimated future temperatures, comparing GCM projections and linear continuation of recent trends.

$\left[{ }^{\circ} \mathrm{F}\right.$, degrees Fahrenheit $]$

\begin{tabular}{|c|c|c|c|c|c|}
\hline \multirow{2}{*}{ Technique } & \multicolumn{3}{|c|}{ Mean annual temperature $\left({ }^{\circ} \mathrm{F}\right)$} & \multicolumn{2}{|c|}{$\begin{array}{c}\text { Estimated mean annual } \\
\text { temperature }\left({ }^{\circ} \mathrm{F}\right)\end{array}$} \\
\hline & 1924-1973 & 1924-1993 & 1995-2014 & $\begin{array}{l}40 \text { years in } \\
\text { future }(2050 \mathrm{~s})\end{array}$ & $\begin{array}{c}80 \text { years in } \\
\text { future }(2090 \mathrm{~s})\end{array}$ \\
\hline Average projection from $22 \mathrm{GCMs}$ & 45.8 & ${ }^{1}$ Set at 46.0 & 47.5 & 51.1 & 53.1 \\
\hline Warming above $1924-1973$ baseline & 0 & 0.5 & 1.7 & 5.1 & 7.3 \\
\hline Warming above $1924-1973$ baseline & 0 & 0.2 & 1.7 & 3.3 & 5.0 \\
\hline
\end{tabular}

\footnotetext{
${ }^{1}$ The southern Colorado Plateau GCM trend-line is quantified as a relative change across the southern Colorado Plateau. This modeled trend can be extrapolated to any specific location as a change relative to the 1924-1993 mean measured at that location, which was $46.0^{\circ} \mathrm{F}$ in the Flagstaff Area.
} 
estimates. The simplistic nature of the linear extrapolation likely underestimates warming beyond the next 30 years. Instead, the linear trend data can be considered as a simplistic, best case scenario for the time periods within a shorter planning horizon. It does not account for the effects of unknown future political or technological changes, or model poorly understood, highly complex atmospheric and oceanic processes or environmental feedbacks. The higher GCM results also shown in table 3 are more likely to occur since they take into account the ever-increasing concentrations of greenhouse gasses in the atmosphere and those feedbacks that can be well quantified. But the complexity of the models can increase skepticism by nonscientists suspicious of climate change science (Lahsen, 2013). In fact, GCMs have proven to be excellent predictors of the temperatures yet to occur when the models were produced (Raisanen, 2007).

Extrapolating the $0.041^{\circ} \mathrm{F}$ per year rate of temperature increase measured over the past 40 years to the next 40 and 80 years projects temperatures much higher than the most recent two decades, the warmest in Flagstaff's recorded history. Applying this low, best case scenario rate of temperature increase projects increases of $3.3^{\circ} \mathrm{F}$ by the $2050 \mathrm{~s}$ and $5.0^{\circ} \mathrm{F}$ by the $2090 \mathrm{~s}$. These temperature increases are well above the historic average (table 3, fig. 3 ) of what had been the more stable climate prior to $1974 .{ }^{10}$ Because the GCM average projects an accelerating warming trend through the next 40 years, its estimated temperatures for later in this century are even higher, producing temperatures $5.1^{\circ} \mathrm{F}$ warmer by the $2050 \mathrm{~s}$ and $7.3^{\circ} \mathrm{F}$ warmer by the $2090 \mathrm{~s}$ (table 3).

There are probably not sufficient data points yet in this observed warming trend to permit the addition of meaningful parametric confidence limits to the projections. But the downscaled climate projections made possible through this type of modeling could become a subject for the future application of Bayesian inference (Min and others, 2007). Because we now have predictions of climate changes that would occur in specific regions, Bayesian probabilities could be updated as additional climate observations become available (Silver, 2013).

The measured temperature warming trends of the past 40 years are very similar to those projected for this period by the GCMs (fig. 5), although the measured temperatures display greater year-to-year variability than the GCM ensemble that averages 48 simulations. The predictions of the A1B $\mathrm{CO}_{2}$ scenario used in these downscaled GCMs has corresponded very well to ongoing measurements (fig. 5). The atmospheric $\mathrm{CO}_{2}$ concentration for the end of 2013, using the $\mathrm{A} 1 \mathrm{~B} \mathrm{CO}_{2}$ scenario of $403 \mathrm{ppm}$, was very close to the observed 398 ppm (Scripps $\mathrm{CO}_{2}$ Program, 2015).

\footnotetext{
${ }^{10}$ Between 1924 and 1973 the standard deviation of mean annual temperatures was $0.99^{\circ} \mathrm{F}$ within a total range of $4.4^{\circ} \mathrm{F}$, while between 1974 and 2014 the standard deviation had increased to $1.11^{\circ} \mathrm{F}$ within a range of $5.2^{\circ} \mathrm{F}$.
}

\section{Comparing Precipitation Trends}

The measured annual precipitation during the most recent 20 years (1995-2014) was 11 percent less (2.3 inches) than the 1924 - 1993 baseline (table 2). This decrease in precipitation occurred over all seasons except the summer monsoon season. The monsoon season precipitation has been increasing, although it has been highly variable from year to year. The 48 runs of $22 \mathrm{GCMs}$ also suggested a roughly 12 percent decline in mean annual precipitation from the 20th century average by the year 2013 (not shown). Although this multimodel mean correlates well with the actual recorded trends, the individual GCM models were extremely variable, especially for the seasonal amounts of precipitation.

An analysis of each GCM's hindcast of 20th century seasonal precipitation suggested that many models lacked sufficient spatial resolution to account for the southwestern monsoon process. Two models, the UKMO-HADGEM1 and the MPI-ECHAM5 GCMs, performed the best (of $22 \mathrm{GCMs}$ ) on portraying 20th century seasonal relative precipitation percentages, accurately reproducing the seasonal precipitation swings that typify the southwestern states (Garfin and others, 2010). Yet these two models depicted opposite futures for monsoon precipitation totals. The UKMO-HADGEM1 suggested a future strengthening of the monsoon especially toward the northwest, into Nevada. In contrast, the MPIECHAM5 suggested a weakening of the monsoon and its withdrawal to the southeast. The most recent 2 years (2013 and 2014) were excellent examples of the type of monsoon strengthening that was projected by the UKMO-HADGEM1 model. This model's projections are an outlier, given that the majority of models did not project any monsoon increase. But the fact that it outscored the other 21 models in hindcasting 20th century seasonal precipitation percentages (Garfin and others, 2010) should invite closer examination.

Because of the arid environment of the southwest, the ongoing and predicted future decline in precipitation depicted by the GCMs is the subject of intense concern and multiple studies. The results, thus far, from both the AR4 (IPCC, 2007) and AR5 (IPCC, 2013) GCM compilations suggest that the ongoing decrease in annual precipitation may continue to worsen (Seager and others, 2007; Seager and others, 2012). Drought conditions will be greatly exacerbated by higher temperatures during dry periods, and the cool-season precipitation could be lowered further by the disappearance of arctic ice cover (Sewall and Sloan, 2004). Although the total amount of precipitation from the summer monsoon is not expected to decline, the arid late-spring drought will continue to worsen through a combination of less precipitation and more severe evapotranspiration (Cook and Seager, 2013).

Many forest species, such as ponderosa pine (Pinus ponderosa) and piñon pine (Pinus edulis), are stressed by higher temperatures during dry periods such as the arid late spring (Allen and others, 2010) and are highly dependent upon the relief from the subsequent summer monsoon. Yet, because the majority of the GCMs incorporated into the AR5 model set do 
not project any future increase in summer monsoon (except for the UKMO-HADGEM1 model), these plant species are modeled to disappear from the Colorado Plateau within this century (McDowell, 2014). However, if the future climate projections from the UKMO-HADGEM1 model are applied instead of the averages from the AR5 dataset, these pine species suffer no mortality (K. Ironside and K.L. Cole, Northern Arizona University, unpub. data, 2011). The agreement between the GCMs and measured recent trends in both decreasing latespring precipitation and increasing late-spring temperatures suggest that the persistence of the forests of the Flagstaff area may be dependent on a future increase in precipitation from summer monsoons. Accordingly, results showing strengthening monsoons such as those from the UKMO-HADGEM1 model are encouraging for the Flagstaff region. A strengthening monsoon may be the most crucial aspect of our changing climate that will be revealed in the coming years.

\section{Summary}

The similarity between temperature and precipitation trends measured during the past 40 years in the Flagstaff area and trends projected by multiple GCMs may be a cause for concern with regard to the region's natural resources, water supply, and some economic resources such as winter industries. Measured ongoing trends of climate warming thus far are nearly identical to those from GCMs and the trends of precipitation are very similar, although changes in the monsoon period remain uncertain. The ensuing years will likely reveal even more about the magnitude of these trends in warming and changes in precipitation.

\section{Acknowledgments}

The development of the downscaled GCMs applied in this paper was supported by funding from the U.S. Department of Energy National Institute for Climatic Change Research project MPC35TV-02 and the U.S. Geological Survey National Climate Change and Wildlife Science Center. Helpful comments were received from two anonymous reviewers and the editor.

\section{References Cited}

Allen, C.D., Macalady, A.K., Chenchouni, H., Bachelet, D., McDowell, N., Vennetier, M., Kitzberger, T., Rigling, A., Breshears, D.D., Hogg, E.H., Gonzalez, P., Fensham, R., Zhang, Z., Castro, J., Demidova, N., Lim, J.-H., Allard, G., Running, S.W., Semerci, A., and Cobb, N., 2010, A global overview of drought and heat-induced tree mortality reveals emerging climate change risks for forests: Forest Ecology and Management, v. 259, no. 4, p. 660-684, available at http://dx.doi.org/10.1016/j.foreco.2009.09.001.
Breshears, D.D., Cobb, N.S., Rich, P.M., Price, K.P., Allen, C.D., Balice, R.G., Romme, W.H., Kastens, J.H., Floyd, M.L., Belnap, J., Anderson, J.J., Myers, O.B., and Meyer, C.W., 2005, Regional vegetation die-off in response to global-change-type drought: Proceedings of the National Academy of Sciences, v. 102, no. 42, p. 15144-15148, available at http://dx.doi.org/10.1073/pnas.0505734102.

Cole, K.L., Ironside, K.E., Arundel, S.T., Duffy, P., and Shaw, J., 2008, Modeling future plant distributions on the Colorado Plateau-An example using Pinus edulis, in van Riper, C., III, and Sogge, M.K., eds., The Colorado Plateau IIIIntegrating research and resources management for effective conservation: Tucson, University of Arizona Press, $\mathrm{p}$. 319-330, available at http://www.fs.fed.us/rm/pubs_other/ rmrs_2008_cole_k001.pdf.

Cook, B.I., and Seager, R., 2013, The response of the North American monsoon to increased greenhouse gas forcing: Journal of Geophysical Research-Atmospheres, v. 118, no. 4, p. 1690-1699, available at http://dx.doi.org/10.1002/ jgrd.50111.

Daly, C., Neilson, R.P., and Phillips, D.L., 1994, A statistical-topographic model for mapping climatological precipitation over mountainous terrain: Journal of Applied Meteorology, v. 33, no. 2, p. 140-158, available at http://dx.doi.org/10.1175/15200450(1994)033<0140:ASTMFM>2.0.CO;2.

Eischeid, J.K., Pasteris, P.A., Diaz, H.F., Plantico, M.S., and Lott, N.J., 2000, Creating a serially complete, national daily time series of temperature and precipitation for the Western United States: Journal of Applied Meteorology, v. 39, no. 9, p. 1580-1591, available at http://dx.doi.org/10.1175/15200450(2000)039<1580:CASCND>2.0.CO;2.

Garfin, G., 2007, Downscaled climate change projections for the southern Colorado Plateau [abs.], in van Riper, C., III, Wakeling, B.F., and Sisk, T.D., 2007, The Colorado Plateau IV_-Proceedings of the 9th Biennial Conference on Colorado Plateau Research, Flagstaff, Ariz., October 2007: Tucson, Ariz., University of Arizona Press, 2144 p.

Garfin, G.M., Eischeid, J.K., Lenart, M.T., Cole, K.L., Ironside, K., and Cobb, N., 2010, Downscaling climate projections in topographically diverse landscapes of Colorado Plateau in the arid Southwestern United States, in van Riper, C., III, Wakeling, B.F., and Sisk, T.D., eds., The Colorado Plateau IV-Shaping conservation through science and management: Tucson, University of Arizona Press, p. 21-44.

Garfin, G., Jardine, A., Merideth, R., Black, M., and LeRoy, S., eds. 2013, Assessment of climate change in the Southwest United States - A report prepared for the National Climate Assessment: Washington, D.C., Island Press, 506 p., available at http://swccar.org/.

Hereford, R., 2007, Climate variation at Flagstaff, Arizona-1950 to 2007: U.S. Geological Survey Open-File Report 2007-1410, 17 p., available at http://pubs.usgs.gov/of/2007/1410/. 
IPCC, 1990, Climate change-The IPCC scientific assessment, in Houghton, J.T., Jenkins, G.J., and Ephraums, J.J., eds., Report prepared for Intergovernmental Panel on Climate Change by Working Group I: Cambridge, England and New York, Cambridge University Press, 410 p., available at https://www.ipcc.ch/publications_and_data/ publications_ipcc_first_assessment_1990_wg1.shtml.

IPCC, 2007, Climate change 2007-The physical science basis, in Solomon, S., Qin, D., Manning, M., Marquis, M., Averyt, K., Tignor, M.M.B., Miller, H.L., Jr., and Chen, Z., eds., Contribution of Working Group I to the Fourth Assessment Report of the Intergovernmental Panel on Climate Change: Cambridge, England and New York, Cambridge University Press, 996 p., available at http:// www.ipcc.ch/report/ar4/wg1/.

IPCC, 2013, Climate change 2013-The physical science basis, in Stocker, T.F., Qin, D., Plattner, G.-K., Tignor, M.M.B., Allen, S.K., Boschung, J., Nauels, A., Xia, Y., Bex, V., and Midgley, P.M., eds., Contribution of Working Group I to the Fifth Assessment Report of the Intergovernmental Panel on Climate Change: Cambridge, England and New York, Cambridge University Press, 1535 p., available at http://www.ipcc.ch/report/ar5/wg1/.

Karl, T.R., Arguez, A., Huang, B., Lawrimore, J.H., McMahon, J.R., Menne, M.J., Peterson, T.C., Vose, R.S., and Zhang, H., 2015, Possible artifacts of data biases in the recent global surface warming hiatus: Science, v. 348, n. 6242, p. 1469-1472.

Kaufmann, R.K., Kauppi, H., Mann, M.L., and Stock J.H., 2011, Reconciling anthropogenic climate change with observed temperature 1998-2008: PNAS, v. 108, n. 29, p. 11790-11793

Lahsen, M., 2013, Anatomy of Dissent-A Cultural Analysis of Climate Skepticism: American Behavioral Scientist, v. 57, no. 6, p. 732-753

Liebmann, B., Bladé, I., Bond, N.A., Gochis, D., Allured, D., and Bates, G.T., 2008, Characteristics of North American summertime rainfall with emphasis on the monsoon: Journal of Climate, v. 21, no. 6, p. 1277-1294, available at http://dx.doi.org/10.1175/2007JCLI1762.1.

McDowell, N.G., 2014, Consistent predictions of future forest mortality [abs.]: American Geophysical Union, Fall Meeting 2014 Abstracts, abstract no. GC21H-02, available at http://abstractsearch.agu.org/meetings/2014/FM/ GC21H-02.html.

McDowell, N.G., Allen, C.D., and Marshall, L., 2009, Growth, carbon-isotope discrimination, and drought-associated mortality across a Pinus ponderosa elevational transect: Global Change Biology, v. 16, p. 399-415, doi:10.1111/ j.1365-2486.2009.01994.x.
Min, S.-K., Simonis, D., and Hense, A., 2007, Probabilistic climate change predictions applying Bayesian model averaging: Philosophical Transactions of the Royal Society A, v. 365, no. 1857, p. 2103-2116, available at http://dx.doi. org/10.1098/rsta.2007.2070.

National Oceanic and Atmospheric Administration, [2014], Climate Data Online: National Centers for Environmental Information database [formerly National Climatic Data Center], accessed February 6, 2014, at http://www.ncdc. noaa.gov/cdo-web/.

National Oceanic and Atmospheric Administration, 2015, State of the climate-Global analysis for annual 2014: National Centers for Environmental Information, accessed January 19, 2016, at http://www.ncdc.noaa.gov/sotc/ global/201413.

Raisanen, J., 2007, How reliable are climate models?: Tellus A, v. 59, no. 1, p. 2-29.

Risbey, J.S., Lewandowsky, S., Langlais, C., Monselesan, D. P., O'Kane, T.J., and Oreskes, N., 2014, Well-estimated global surface warming in climate projections selected for ENSO phase: Nature Climate Change, v. 4, p. 835-840.

Salathé, E.P., Jr., 2005, Downscaling simulations of future global climate with application to hydrologic modelling: International Journal of Climatology, v. 25, no. 4, p. 419-436, available at http://dx.doi.org/10.1002/joc.1125.

Scripps $\mathrm{CO}_{2}$ Program, 2015, Atmospheric $\mathrm{CO}_{2}$ data: Scripps $\mathrm{CO}_{2}$ Program database, accessed February 6, 2014, at http:// scrippsco2.ucsd.edu/data/atmospheric_co2.html.

Seager, R., Ting, M., Held, I., Kushnir, Y., Lu, J., Vecchi, G., Huang, H.-P., Harnick, N., Leetmaa, A., Lau, N.-C., Li, C., Velez, J., and Naik, N., 2007, Model projections of an imminent transition to a more arid climate in southwestern North America: Science, v. 316, no. 5828, p. 1181-1184, available at http://dx.doi.org/10.1126/science.1139601.

Seager, R., Ting, M., Li, C., Naik, N., Cook, B., Nakamura, J., and Liu, H., 2012, Projections of declining surface-water availability for the southwestern United States: NatureClimate Change, v. 3, p. 482-486, available at http://dx.doi. org/10.1038/nclimate 1787 .

Sellers, W.D., and Hill, R.H., eds., 1974, Arizona climate, 19311972 (2d ed.): Tucson, University of Arizona Press, 616 p.

Sewall, J.O., and Sloan, L.C., 2004, Disappearing Arctic sea ice reduces available water in the American west: Geophysical Research Letters, v. 31, no. 6, available at http://dx.doi.org/10.1029/2003GL019133.

Sheppard, P.R., Comrie, A.C., Packin, G.D., Angersbach, K., and Hughes, M.K., 2002, The climate of the US Southwest: Climate Research, v. 21, no. 3, p. 219-238, available at http://dx.doi.org/10.3354/cr021219. 
Silver, N., 2013, The Signal and the Noise-The Art and Science of Prediction: New York, Penguin, $560 \mathrm{p}$.

Smith, H.V., 1956, The climate of Arizona: Tucson, Ariz., University of Arizona, Arizona Agricultural Experiment Station Bulletin 279, 99 p., available at http://arizona. openrepository.com/arizona/handle/10150/213130.

Solomon, L., 2007, Fighting climate 'fluff': National Post [Canada], April 23, 2007.

Staudenmaier, M., Jr., Preston, R., and Sorenson, P., 2007, Climate of Flagstaff, Arizona: National Oceanic and Atmospheric Administration, National Weather Service Technical Memorandum NWS WR-95, 69 p.

Steenburgh, W.J., Redmond, K.T., Kunkel, K.E., Doesken, N., Gillies, R.R., Horel, J.D., Hoerling, M.P., and Painter, T.H., 2013, Present weather and climate-Average conditions, chap. 4 of Garfin, G., Jardine, A., Merideth, R., Black, M., and LeRoy, S., eds., Assessment of climate change in the Southwest United States-A report prepared for the National Climate Assessment: Washington, D.C., Island Press, p. 56-73, available at http://swccar.org/chapter/4.

van Riper, C., III, Hatten, J.R., Giermakowski, J.T., Mattson, D., Holmes, J.A., Johnson, M.J., Nowak, E.M., Ironside, K., Peters, M., Heinrich, P., Cole, K.L., Truettner, C., and Schwalbe, C.R., 2014, Projecting climate effects on birds and reptiles of the Southwestern United States: U.S. Geological Survey Open-File Report 2014-1050, 100 p., available at http://dx.doi.org/10.3133/ofr20141050.

Western Regional Climate Center, [2014] Western U.S. climate summaries-NOAA cooperative stations: Western Regional Climate Center database, accessed February 6, 2014, at http://www.wrcc.dri.edu/climatedata/climsum/.

Westerling, A.L., and Swetnam, T.W., 2003, Interannual to Decadal Drought and Wildfire in the Western United States: Eos, v. 84, n.49, p. 545-555. 


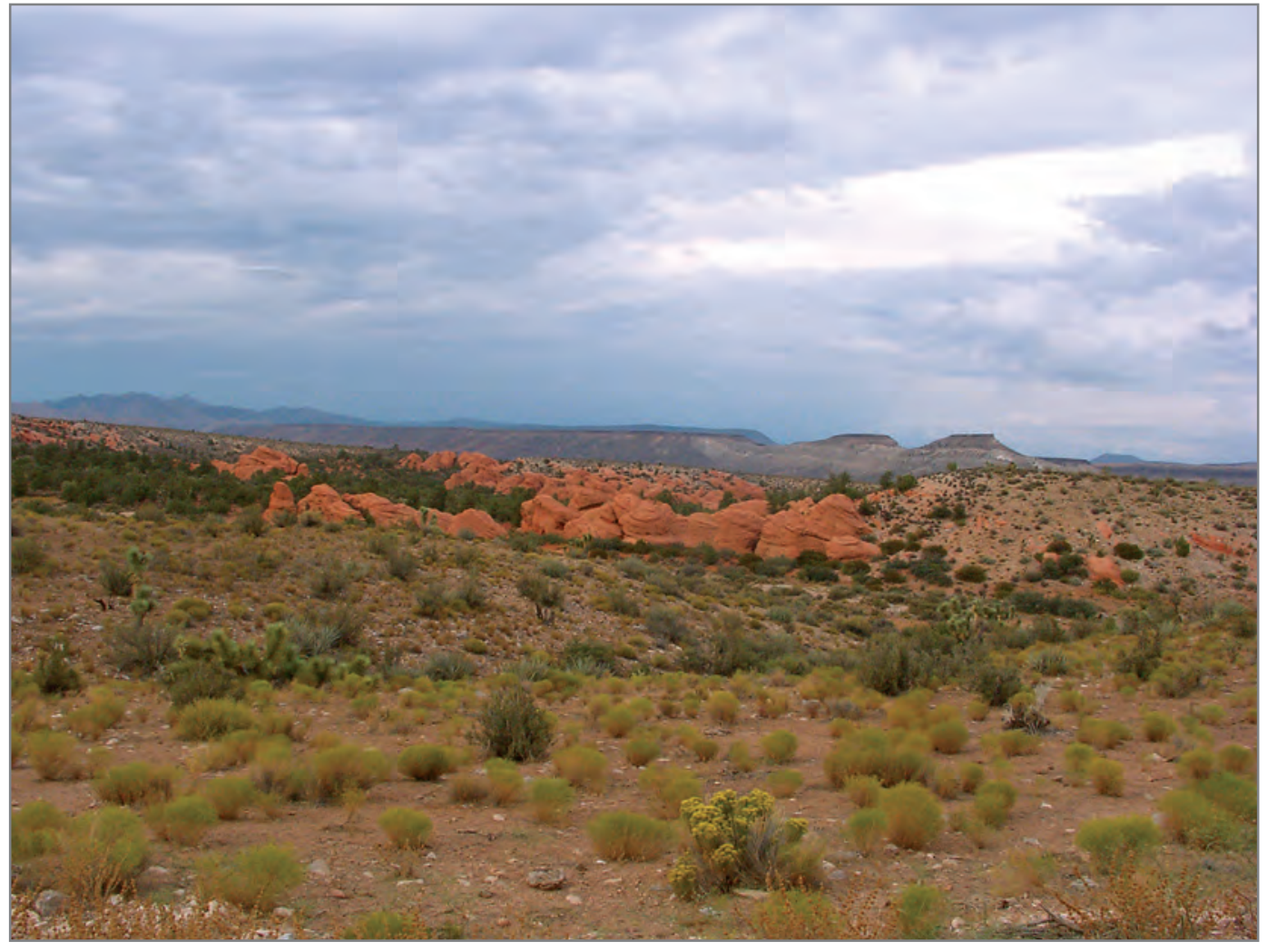

In Parashant National Monument, Arizona. Photograph by Robert J. Hart, U.S. Geological Survey. 


\title{
Ecological Inventory and Assessment of Springs Ecosystems in Kaibab National Forest, Northern Arizona
}

\author{
By Jeri D. Ledbetter, ${ }^{1}$ Lawrence E. Stevens, ${ }^{1}$ Marguerite Hendrie, ${ }^{1}$ and Arie Leonard ${ }^{2}$
}

\section{Abstract}

Springs are ecosystems in which groundwater emerges at, and generally flows from the Earth's surface. Although poorly mapped, studied, and managed, springs function as hotspots of biodiversity that support a wide array of rare and endemic taxa, and commonly serve as keystone ecosystems. To assist Kaibab National Forest with improved stewardship and greater understanding of springs ecosystem integrity, we conducted inventories on the ecohydrology of forest springs from 2010 to 2012. We compiled data for 205 springs from several public sources and data contributed by collaborating researchers and conservation organizations. We conducted surveys of 52 springs and measured site characteristics, flow, water quality, biota, habitat, and human influences on a total area of 6.01 hectares (ha) of springs-influenced habitat.

The Kaibab National Forest region is estimated to support 1,325 plant taxa across 647,500 ha ( 0.0034 species per hectare). We detected 441 plant species on our inventories, for a density of 72.5 plant species per hectare at springs. Although species-area constraints influenced these results, we detected one-third of the regional flora in $<0.001$ percent of the landscape, representing a remarkable concentration of plant species richness at springs. Here, we present the results of a 2-year ecological inventory and characterization of the springs ecosystems in Kaibab National Forest that will provide a basis for prioritizing springs protection and restoration and for detecting ecologic changes over time.

\section{Introduction}

Springs are ecosystems in which groundwater emerges at, and generally flows from the Earth's surface (Springer and Stevens, 2008; Stevens and Meretsky, 2008). Although springs have generally been poorly mapped, studied, and managed, they are far more abundant than is usually recognized. Springs are hotspots of biodiversity, supporting a wide array of rare and endemic taxa, and commonly function as keystone ecosystemssmall habitats that play disproportionally large roles in the

${ }^{1}$ Springs Stewardship Institute, Museum of Northern Arizona

${ }^{2}$ Kaibab National Forest ecology of the surrounding landscape (Perla and Stevens, 2008). Springs are widely regarded by indigenous cultures as important sites for religious, educational, and resource uses. Springs also are commonly used and managed for domestic and livestock water supplies. Despite their biological, cultural, and economic importance, springs are commonly degraded by human activities.

Knowledge of the distribution, ecosystem ecology, and ecological integrity of the springs in North America (Ceroici and Prasad, 1977; Williams and Danks 1991; Stevens and Meretsky, 2008; Hallam, 2010) is increasing, and the springs in northern Arizona and southern Utah are beginning to receive scientific attention (Grand Canyon Wildlands Council, 2002; Flora, 2004). The Springs Stewardship Institute (SSI)'s mapping of Arizona springs provides one of the few comprehensive statelevel mapping efforts in the Western United States (Ledbetter and others, 2012; see also Howard and Merrifield, 2010). Although the flow and quality of water have been monitored at several individual springs in northern Arizona, most springs in the region have not been studied, and many have not been mapped. Although scientific studies have begun to contribute to a wider understanding of the distribution and ecologic integrity of northern Arizona springs, we still have much to learn. Such efforts are timely, given society's increasing demand for water and other springs-related resources, and the declines in some springs-specialist taxa, such as the northern leopard frog (Ranidae: Lithobates pipiens).

\section{Methods}

\section{Study Area}

Here, we present the results of a 2-year ecohydrologic inventory and characterization of the springs in Kaibab National Forest, Ariz. (fig. 1). The forest, which occupies an area of 6,475 square kilometers $\left(\mathrm{km}^{2}\right)$ in central northern Arizona, is topographically diverse, with elevations ranging from 900 meters (m) in Kanab Canyon to 2,800 m near the North Rim of the Grand Canyon. The forest comprises three ranger districts: the North Kaibab Ranger District, north of the Grand Canyon (area, $\left.2,652 \mathrm{~km}^{2}\right)$; the Tusayan Ranger District, south of the Grand Canyon (area, 1,341 km²); and the Williams Ranger District, 
west of Flagstaff, Ariz. (area, 2,482 $\mathrm{km}^{2}$ ). The North Kaibab

Ranger District lies across the East Kaibab monocline, a northtrending dome that rises 1,000 $\mathrm{m}$ above the Coconino platform, bounded by Marble Canyon to the east and the Kanab Creek drainage to the west. The Tusayan Ranger District occupies the tablelands of the Coconino platform immediately south of the Grand Canyon, and the Williams Ranger District includes the volcanic hills and mountains near the southern edge of the Colorado Plateau in the vicinity of Williams, Ariz. (fig. 1).
The climate of Kaibab National Forest is arid and continental, with cold high-elevation winters, hot lowelevation desert summers, and a short growing season (Sellers and others, 1985). Precipitation averages $\sim 550$ millimeters per year ( $\mathrm{mm} / \mathrm{yr})$ and is distributed bimodally, with summer monsoonal rains and winter snowfall and rain, which is the primary contributor to groundwater recharge. The forest includes floristic elements of the Cordilleran, Intermountain, Mohavean/Sonoran, and Madrean biomes, with a

Figure 1. Map of northern Arizona, showing two study areas for springs inventory in North Kaibab $(A)$ and Williams $(B)$ Ranger Districts.
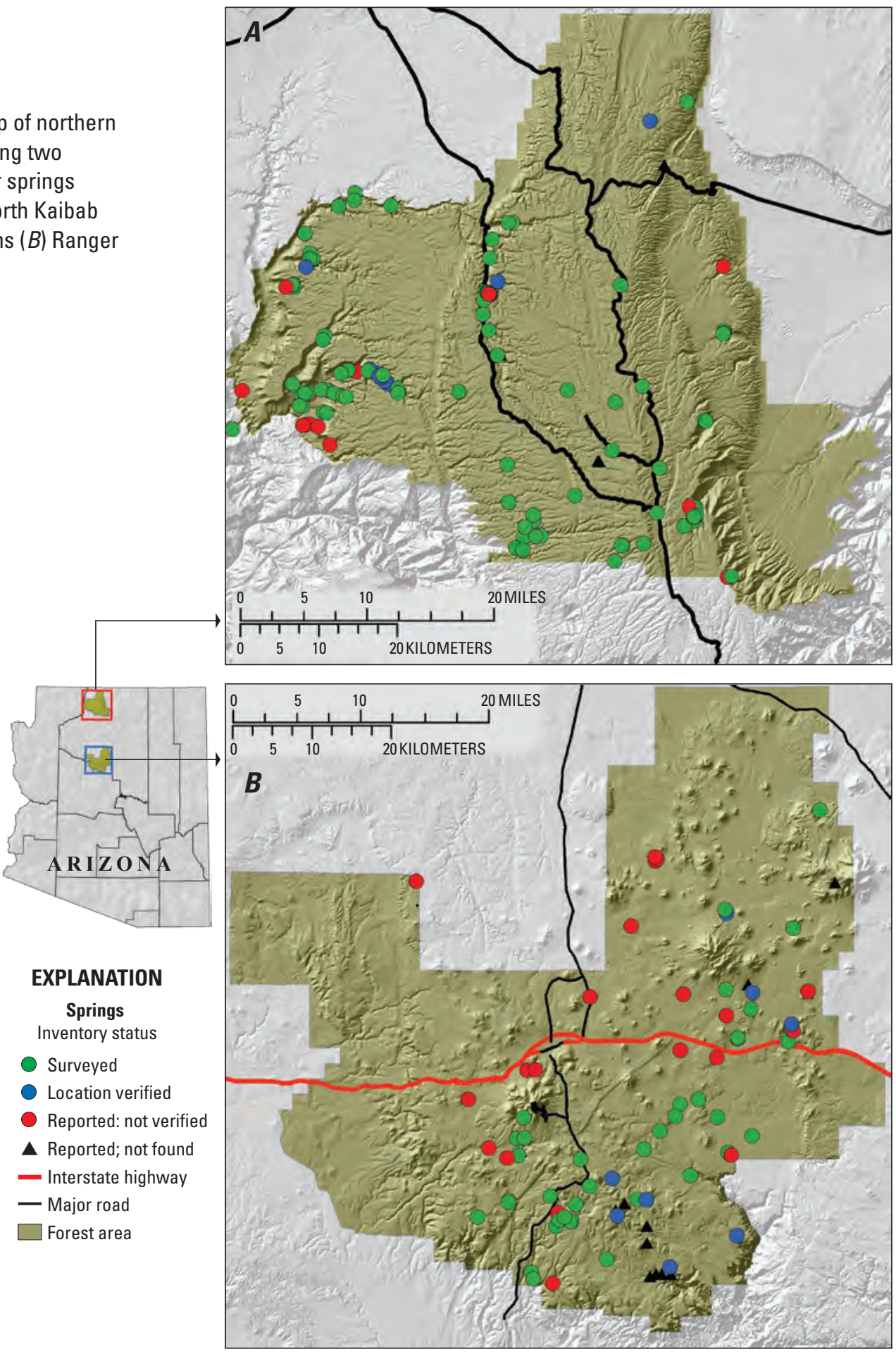
low-elevation desert habitat occupied by Madrean, Sonoran, and Mohavean Desert shrub vegetation, middle-elevation habitats dominated by intermountain Great Basin grasslands and piñon-juniper woodlands, and upper elevation plateaus occupied by cordilleran Rocky Mountain ponderosa pine (Pinus ponderosa) and mixed conifer forests, with large grassor sagebrush- (Artemesia spp.) dominated meadows.

\section{Data Compilation}

Before conducting our fieldwork, we completed a level 1 springs inventory of Kaibab National Forest, according to the protocols of Stevens and others (2011). Our inventory involved compiling data from available sources to locate previously reported springs. Datasets from the Arizona State Land Office $(1993,2008)$ provided the bulk of location information. We also visually scanned each 7.5-minute U.S. Geological Survey (USGS) digital-raster-graphic (DRG) topographic-quadrangle map to locate additional springs, and reviewed applicable environmental impact statements (U.S. Forest Service, 1986; Bureau of Land Management, 2011). We imported data from several previous springs inventories, including those by Brown and Moran (1979), the Grand Canyon Wildlands Council, (2002, 2005), and the Grand Canyon Trust (unpub. data, 2011), as well as information provided by the U.S. Forest Service (FS). We compiled these data into the SSI Springs Inventory Database (Ledbetter and others, 2012).

\section{Field Methods}

Our field inventory used the level 2 springs inventory protocols of Stevens and others (2011). These rapid survey and inventory methods include a comprehensive suite of field measurements that describe physical characteristics of the ecosystem. A team of three to five researchers visited each site for 1-3 hours, measuring and (or) assessing site characteristics, flow, geochemistry, geomorphology, habitat structure, vegetation composition, aquatic and wetland fauna, human influences, and resource management context.

Upon arriving at a springs ecosystem, we noted any avian and wildlife presence and then prepared a field sketchmap of the site, identifying the location, orientation, size, slope angle, and soil characteristics of each springs-supported geomorphologically defined microhabitat, as well as the locations of photographs and the places where we measured water quality, solar radiation, and flow.

We measured water flow downstream from the source at a point that was judged to represent the total discharge from the springs. Flow was typically measured using timed volumetric capture or a weir plate. We measured field water-quality variables as close to the source as possible, recording $\mathrm{pH}$, water and air temperatures, specific conductance, dissolved oxygen concentration, and alkalinity, where possible. For some springs, we also collected filtered water samples for laboratory analyses of stable isotopes $\left({ }^{18} \mathrm{O}\right.$ and $\left.{ }^{2} \mathrm{H}\right)$, nutrients, and major cations and anions.

We visually estimated the percentage cover of surficial grains or soils using a modified sediment grain-size scale ranging from 1 (clay) to 8 (bedrock), or organic soils/peat. We also visually estimated the percentage cover of each vascular plant species growing on or hanging over each microhabitat, using the taxonomic nomenclature, nativity, and habitat affiliation of the U.S. Department of Agriculture. We evaluated vegetation structure within the following cover strata: aquatic, nonvascular, basal (large-woody-stem emergence at ground level), ground (graminoid or herbaceous-deciduous), shrub (>4-m-high woody shrub), middle canopy (4-10-m-high woody perennial), and tall canopy ( $>10$-m-high woody perennial).

We opportunistically sampled and, where sufficient flow permitted, conducted replicated quantitative kicknet sampling for springs' benthic invertebrates by sampling an area-defined portion of the benthos for 1 minute. Specimens were returned to the laboratory for enumeration, preparation, and identification, using the taxonomy of Merritt and others (2008), with identification of species where possible. Specimens are curated at the Museum of Northern Arizona.

We assessed the overall quality of the springs by using the SSI Springs Ecosystems Assessment Protocol (SEAP) of Stevens and others (2011) to determine the ecologic integrity (condition) of, and risks to, the springs in relation to the adjacent landscape. In this assessment, the condition or value and the risk (inverse of rehabilitation potential) were scored on a scale from 0 (no condition or value, no risk) to 6 (high condition or value, overwhelming risk with no recovery potential) for each of 42 resource or management variables, among 6 categories of information: aquifer and groundwater quality, geomorphology, habitat quality, biota, freedom from human impacts, and administrative context (see http://docs. springstewardship.org/PDF/SEAPCulturalApril2012.pdf). The administrative context variables were quantified through interviews with the springs steward(s).

\section{Analyses}

Analysis of nutrients and major cations and anions was conducted at the University of Arizona's Water Quality Certification (WQC) laboratory, and analysis of stable isotopes $\left({ }^{18} \mathrm{O}\right.$ and $\left.{ }^{2} \mathrm{H}\right)$ at Northern Arizona University's water quality laboratory. We used visual graphic inspection and simple linear regression to evaluate the extent of linearity in response variables. We used compiled data to determine relation among springs types and associated ecosystem characteristics (Springer and Stevens, 2008), and evaluated the differences in some of those characteristics between the North Kaibab and Williams Ranger Districts. We calculated the geomorphic diversity of each springs ecosystem as the Shannon-Weiner diversity index (as reviewed by Spellerberg and Fedor, 2003), using the proportional cover of each geomorphic microhabitat influenced by the spring. We also calculated plant morphospecies richness within strata and sites 
(Shannon-Weiner plant morphospecies diversity) and visually estimated percentage cover within each vegetation stratum. We used the SEAP protocols to determine the ecologic integrity of each springs visited, and whether the springs' ecological condition met the FS stewardship expectations.

\section{Information Management}

We entered the inventory data, along with a representative photograph and a sketchmap, into the SSI Springs Inventory Database (Ledbetter and others, 2012). Each study site was included in a geodatabase to relate survey data to Geographic Information Systems (GIS) mapping applications using a common site identification number. All data were also provided to the FS.

\section{Results}

SSI staff and volunteers visited 71 springs in the Kaibab National Forest in 2011-12, conducting level 2 inventories on 52 springs and level 1 (georeferencing) inventories on 8 springs, and observed 12 springs to be either dry or nonexistent (table 1). In addition, we compiled survey data from previous studies on 134 springs, including those studies by the Grand Canyon Wildlands Council $(2002,2005)$ and the Grand Canyon Trust (unpub. data, 2011). Including the pre-fieldwork literature search, we obtained at least some information on 205 springs, although 19 were either dry or unlocatable. Survey crews also found 7 springs that had not previously been mapped or described. Miller Spring, the only springs ecosystem reported in the Tusayan Ranger District, had previously been reported as dry and was dry at the time of our site visit in November 2012. Not all data were available for each spring; therefore sample size differs among variables.

\section{Aquifers}

Many of the aquifers in Kaibab National Forest are perched and stacked, with uppermost, younger basalt flows overlying deeper Paleozoic strata, particularly the Kaibab, Toroweap, Coconino, Supai Group, and Redwall Formations (Kreamer and Springer, 2008; Crossey and Karlstrom, 2012). Most springs in the Williams Ranger District emerge from shallow aquifers in basalt flows, whereas those in the North Kaibab Ranger District primarily emerge from the deeper Kaibab, Toroweap, and Coconino Formations. Water temperature and solute concentration typically increase with depth through these strata, but groundwater emerging from the Toroweap/Coconino Formation contact in the North Kaibab Ranger District is more solute rich than other waters in Kaibab National Forest, as discussed below.

\section{Springs Habitat Area}

A sample of 81 springs for which sufficient data existed for detailed comparison occupied a total area of 6.01 ha of springs habitat, ranging widely in area from 4.5 to $15,036 \mathrm{~m}^{2}$ and averaging $742 \mathrm{~m}^{2}$ (95-percent-confidence interval, $406.3 \mathrm{~m}^{2}$ ), with a median area of $166 \mathrm{~m}^{2}$.

\section{Springs Types}

We detected 9 of the 12 types of terrestrial springs recognized by Springer and Stevens (2008), among 90 springs for which sufficient data were available to determine springs types (table 2). Because much of Kaibab National Forest consists of rolling plateaus, the preponderance of low-gradient springs types (for example, hillslope, rheocrene, and helocrene) is not surprising. However, lands in the steep terrain of the Kanab Creek drainage in the North Kaibab Ranger District support hanging gardens, and additional unmapped springs remain to be located, georeferenced, and inventoried there.

\section{Flow}

The average flow of the 75 springs for which data were available varied widely (mean, 0.53 liters per second (L/s); 95 -percent-confidence interval, $\pm 0.365 \mathrm{~L} / \mathrm{s}$ ). Springs discharge ranged from perennial, apparently groundwater-fed ponds and minor seeps with no detectable flow, to springs with a flow of $>1.0 \mathrm{~L} / \mathrm{s}$, including Big Spring (as much as $12.3 \mathrm{~L} / \mathrm{s}$ ) in the North Kaibab Ranger District, Slide Spring (4.4 L/s), Lower North Canyon Spring (2.78 L/s), Pipe Springs on Camp Navajo (1.91 L/s), and Glenn Rink Spring (1.9 L/s). Glenn Rink Spring was notable, owing to its lengthy $(>600 \mathrm{~m})$ runout and significant contribution to North Canyon Creek, which supports Apache trout and at least five narrowly endemic invertebrate taxa. In spite of its having the fourth-highest flow measured in the North Kaibab Ranger District, Glenn Rink Spring had not previously been mapped or described. Few repeated measurements of flow have been performed on the springs in the Kaibab National Forest, but the Grand Canyon Wildlands Council $(2002,2005)$ reported that the flow from Big Springs in the North Kaibab Ranger District decreased from 12.3 to $0.867 \mathrm{~L} / \mathrm{s}$ in the period $2000-01$. Such widely varying flows characterize the cold-water springs emanating from the Redwall and Muav Formations in nearby Grand Canyon National Park (for example, Vaseys Paradise, Roaring Springs, Thunder River Spring, and Dutton Spring). Big Springs in the North Kaibab Ranger District is one of the few Coconino Aquifer springs known to have such a widely varying flow. Our surveys indicated that at least 9.3 percent of the springs in the Kaibab National Forest are ephemeral. 
Table 1. Data for springs at which inventories were conducted in Kaibab National Forest from 2010 to 2012.

[Locations: NC, central North Kaibab Ranger District; NE, east side of North Kaibab Ranger District; NW, west side of North Kaibab Ranger District; RD, ranger district; S, Williams Ranger District. Springs types: C, cienega/helocrene/springfed fen; G, gushet; H, hillslope; HG, hanging garden; L, limnocrene; LGC, low-gradient cienega; R, rheocrene. Aquifers: B, neogene basalt; C, Coconino; H, Hermit Shale; K, Kaibab; Su, Supai; T, Toroweap Formation. ${ }^{\circ} \mathrm{C}$, degrees Celsius; -, no data]

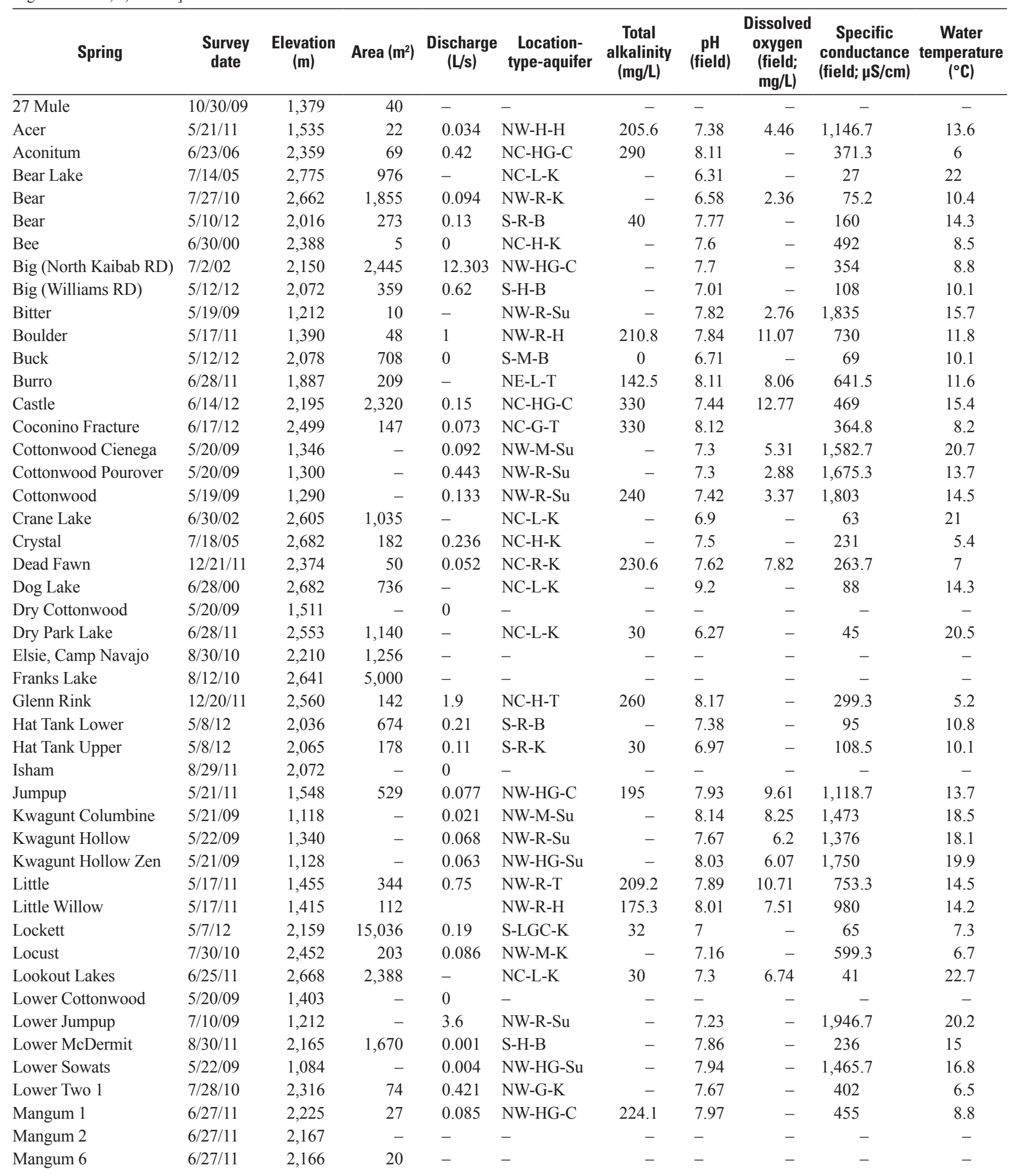


Table 1.-Continued

\begin{tabular}{|c|c|c|c|c|c|c|c|c|c|c|}
\hline Spring & $\begin{array}{l}\text { Survey } \\
\text { date }\end{array}$ & $\begin{array}{l}\text { Elevation } \\
\text { (m) }\end{array}$ & Area $\left(\mathrm{m}^{2}\right)$ & $\begin{array}{c}\text { Discharge } \\
\text { (L/s) }\end{array}$ & $\begin{array}{l}\text { Location- } \\
\text { type-aquifer }\end{array}$ & $\begin{array}{c}\text { Total } \\
\text { alkalinity } \\
\text { (mg/L) }\end{array}$ & $\underset{\text { (field) }}{\mathrm{pH}}$ & $\begin{array}{l}\text { Dissolved } \\
\text { oxygen } \\
\text { (field; } \\
\text { mg/L) }\end{array}$ & $\begin{array}{c}\text { Specific } \\
\text { conductance } \\
\text { (field; } \mu \mathrm{S} / \mathrm{cm} \text { ) }\end{array}$ & $\begin{array}{c}\text { Water } \\
\text { temperature } \\
\left({ }^{\circ} \mathrm{C}\right)\end{array}$ \\
\hline Mangum & $6 / 27 / 11$ & 2,163 & 100 & 0.02 & NW-HG-C & 280.6 & 8.05 & 7.9 & 322.6 & 9.4 \\
\hline McDermit & $8 / 30 / 11$ & 2,200 & 400 & 0.022 & S-M-K & - & 7 & - & 206 & 21.1 \\
\hline Mountain Sheep & $8 / 17 / 09$ & 1,130 & 467 & 1.7 & NW-H-S & - & 7.29 & - & $1,726.7$ & 18.4 \\
\hline North Canyon Lower & $6 / 28 / 00$ & 2,485 & 250 & 2.776 & NC-H-T & - & 8.4 & - & 323 & 5.8 \\
\hline North Canyon Middle & $6 / 25 / 01$ & 2,534 & 16 & 0.419 & NC-H-T & - & 8.7 & - & 322 & 6.5 \\
\hline North Canyon Upper & $6 / 28 / 00$ & 2,513 & 5 & 0.059 & NC-H-T & - & 9 & - & 313 & 5.7 \\
\hline Oak & $6 / 16 / 12$ & 2,054 & 94 & 0.011 & NW-H-T & 310 & 7.88 & - & 354.2 & 12.1 \\
\hline Oquer & $6 / 28 / 11$ & 2,550 & 24 & 0.018 & NW-H-K & 148.8 & 7.72 & 6.9 & 189.6 & 8.8 \\
\hline Pigeon & $5 / 18 / 11$ & 1,506 & 125 & 0.001 & NW-HG-T & 243.3 & 7.2 & 4.46 & 1,960 & 12.1 \\
\hline Pipe, Camp Navajo & $9 / 24 / 10$ & 2,167 & 1,298 & 1.91 & S-LGC-K & - & 6.82 & - & 203 & 12.6 \\
\hline Quaking Aspen & $7 / 13 / 05$ & 2,398 & 114 & 0.153 & NE-C-K & - & 7.5 & - & 444 & 9.6 \\
\hline Riggs & $6 / 29 / 11$ & 2,264 & - & 1.322 & NE-C-K & 205.4 & 7.84 & - & 390 & 9.5 \\
\hline Rock Lower & $11 / 2 / 09$ & 1,328 & 1,323 & 1 & NW-HG-M & - & 8.1 & - & 2,600 & 13.9 \\
\hline Rock Upper Bowl & $11 / 2 / 09$ & 1,345 & 166 & 0.1 & - & - & - & - & - & - \\
\hline Rocky Tule & $9 / 27 / 10$ & 2,012 & - & - & - & - & - & - & - & - \\
\hline Rosilda & $5 / 12 / 12$ & 2,046 & 591 & 0.29 & S-R-K & 0 & 6.68 & & 77 & 10.1 \\
\hline Slide & $7 / 8 / 10$ & 1,490 & 125 & 4.3 & NW-R-T & 240 & 7.46 & 9.6 & $1,216.7$ & 15.5 \\
\hline Solidago & $5 / 20 / 11$ & 1,765 & 165 & 0.023 & NW-HG-C & 199.2 & 8.46 & 10.82 & 540 & 12.1 \\
\hline Summit & $5 / 10 / 12$ & 2,212 & 39 & 0 & - & - & - & - & - & - \\
\hline Table Rock & $5 / 16 / 11$ & 1,613 & 450 & 0.004 & NW-HG-T & 148.3 & 8.28 & 11.26 & $1,496.7$ & 13.5 \\
\hline Tappan, Camp Navajo & $9 / 21 / 10$ & 2,233 & 3,050 & 0.017 & - & - & - & - & - & - \\
\hline Tater Canyon & $7 / 15 / 05$ & 2,260 & 113 & - & NE-HG-C & - & - & - & - & 11.5 \\
\hline Tater Canyon Upper & $7 / 15 / 05$ & 2,345 & 42 & 0.257 & - & - & - & - & - & \\
\hline Tilton & $6 / 27 / 11$ & 2,099 & 60 & 0.003 & NW-H-H & 264.4 & 8.11 & - & - & 12.1 \\
\hline Timp & $8 / 3 / 05$ & 2,416 & 1,550 & 0.186 & NC-H-K & - & 7.46 & - & 478 & 7.3 \\
\hline Trailview & $6 / 17 / 12$ & 2,538 & 120 & 0 & - & - & - & - & - & - \\
\hline Typha & $5 / 19 / 11$ & 1,408 & 43 & 0.015 & NW-H-H & 210 & 7.95 & 9.43 & $1,256.7$ & 14.2 \\
\hline Unnamed 8 & $5 / 19 / 09$ & 1,410 & - & - & NW-HG-H & - & 7.56 & - & 1,269 & 17.4 \\
\hline Upper Sowats & $5 / 22 / 09$ & 1,107 & - & - & NW-HG-T & - & 7.96 & - & $1,579.7$ & 18.9 \\
\hline Upper Two & $8 / 7 / 00$ & 2,377 & 100 & - & NW-R-K & - & 7.6 & - & 517 & 21.5 \\
\hline VT Lake & $6 / 16 / 12$ & 2,689 & 3,666 & - & NC-L-K & 50 & 9.33 & - & 41.9 & 14.5 \\
\hline Warm & $12 / 30 / 05$ & 2,109 & 37 & 0.36 & NW-Ca-C & 165.6 & 7.8 & - & 610 & 14.5 \\
\hline Watts & $7 / 14 / 05$ & 2,442 & 151 & 0.076 & NW-H-K & - & 7.5 & - & 497 & 8 \\
\hline White & $5 / 19 / 09$ & 1,390 & - & - & NW-H-H & - & 7.66 & - & $1,322.7$ & 18.7 \\
\hline Wild Horse & $5 / 11 / 12$ & 2,041 & 77 & 0.034 & S-R-B & 40 & 6.62 & - & 75 & 14.6 \\
\hline Wild Horse Upper & $5 / 11 / 12$ & 2,050 & 167 & 0.004 & S-R-B & 80 & 8.58 & - & 94 & 20.9 \\
\hline Wildband & $5 / 18 / 11$ & 1,545 & 1,198 & 0.008 & NW-H-T & 160 & 8.44 & 10.08 & 2,000 & 13.2 \\
\hline Willow & $8 / 29 / 11$ & 1,980 & 720 & - & - & - & - & - & - & - \\
\hline
\end{tabular}


Table 2. Abundance of springs types reported in Kaibab National Forest.

$[n=90 ;$ from Springer and Stevens (2008)]

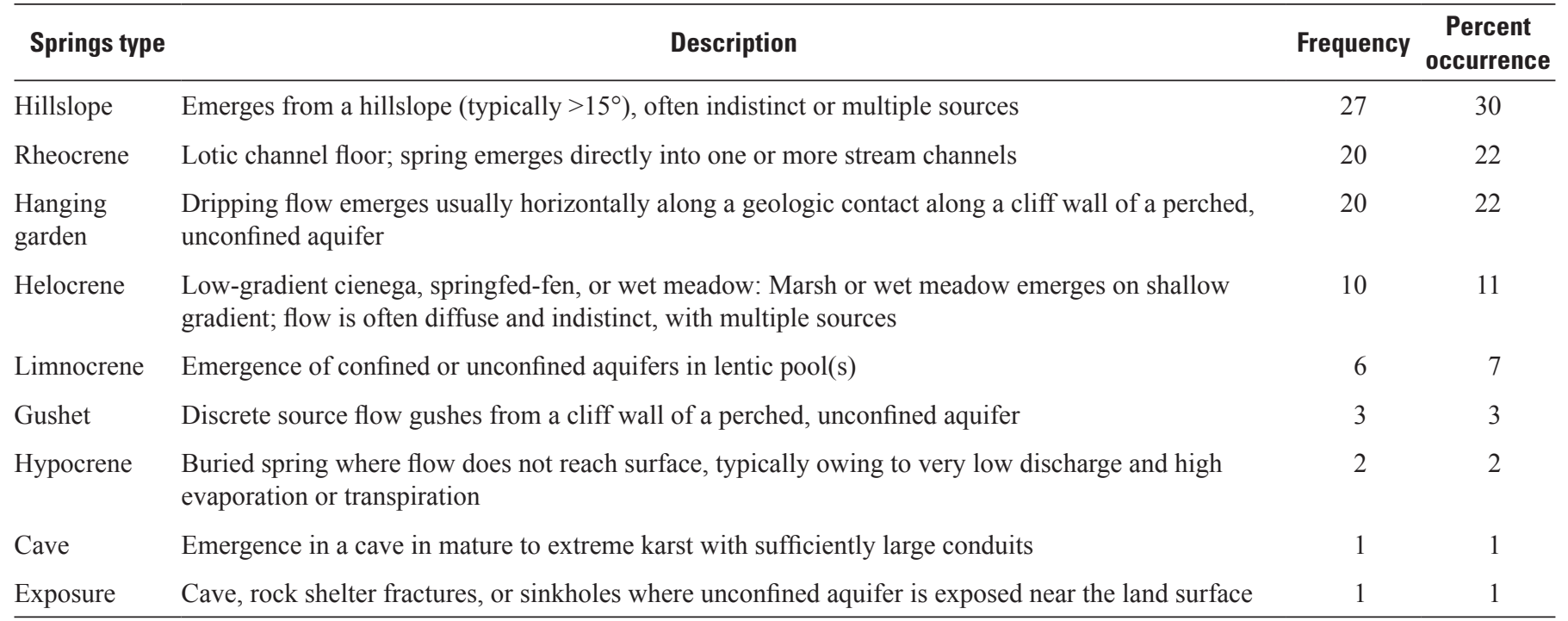

\section{Water Quality}

We measured field water-quality variables and compiled water-quality data for 83 springs (table 1). Temperature, $\mathrm{pH}$, and specific conductance were recorded for 52 springs. In addition to these variables, dissolved oxygen concentrations were measured at 29 sites, and field alkalinity was measured at 43 springs (table 1 ).

Field water quality varied by elevation, aquifer parent rock, and across the Kaibab monocline. In the North Kaibab Ranger District, the central Kaibab Plateau had higher field $\mathrm{pH}$ values, lower specific conductances, and intermediate water temperatures relative to springs on the east and west sides of the plateau (table 1). Springs on the west side of the monocline commonly discharge from or near the bottom of the Toroweap Formation and drain into Kanab Creek. These springs typically had higher specific conductances and water temperatures and

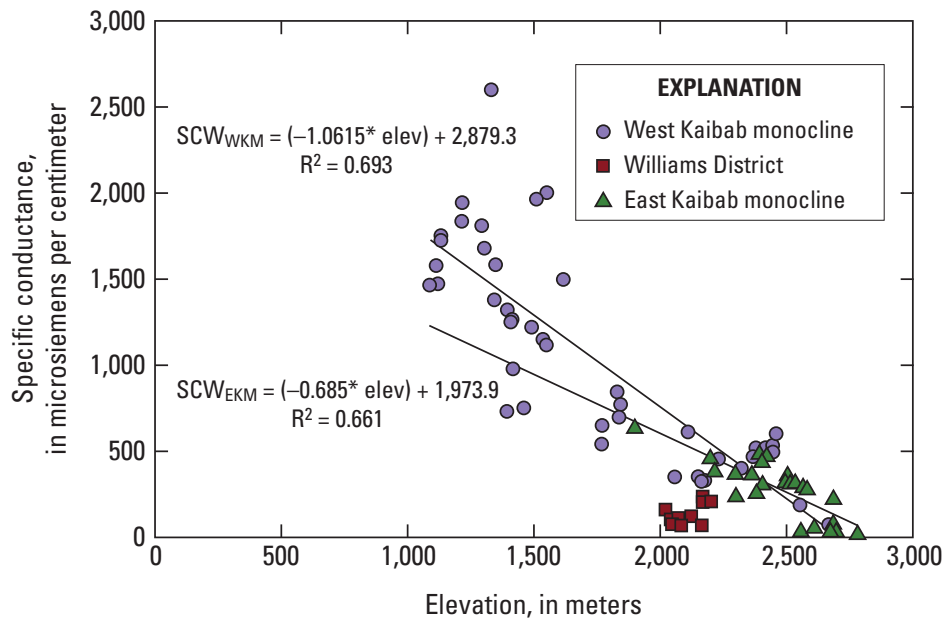

lower $\mathrm{pH}$ values, particularly those at the lowest elevations (for example, the Rock Springs complex). In contrast, many of the springs on the east side of the monocline emerge from the base of the Coconino Formation. Springs in the Williams Ranger District, which primarily emerge from Neogene basalt flows, had the lowest average $\mathrm{pH}$ values and specific conductances, and the highest average water temperatures (table 1).

Stable isotope ratios for oxygen generally indicated relatively low levels of ${ }^{18} \mathrm{O}$ enrichment, consistent with the dominant, shallow, high-elevation aquifers of the Colorado Plateau. This relation was particularly true in perennial ponds, which have significant direct input from precipitation and, therefore, a higher concentration of lighter oxygen isotopes.

Specific conductance was negatively related to varying degrees among strata and hydrologic subbasins, and therefore by elevation (fig. 2). This relation may also be due to
Figure 2. Plot of specific conductance verses elevation at springs on the west and east sides of the Kaibab monocline in the North Kaibab and Williams Ranger Districts in Kaibab National Forest, northern Arizona. See figure 1 for locations. 
variation in the levels of evaporative concentration of water pre-recharge and (or) post-discharge. Although specific conductance did not vary much across the limited elevation gradient in the Williams Ranger District, it varied in a strongly inverse fashion across elevation on both the East and West Kaibab monoclines $\left(R^{2}, 0.661\right.$ and 0.693 , respectively). Springs on the west side of the Kaibab upwarp occur across a wider elevation range than elsewhere in Kaibab National Forest, and the lowest elevation springs (that is, those in the Kanab Creek drainage) commonly had fivefold greater specific conductance relative to springs at higher elevations.

\section{Geomorphic Diversity}

Geomorphic diversity (Shannon-Weiner proportional area of different microhabitats in relation to the overall springs ecosystem) has been positively correlated with plant species richness at springs (Hallam, 2010; Springer and others, 2014). Geomorphic diversity varied among springs types, with an overall average of 0.32 . Gushets and hanging gardens had the highest overall geomorphic diversity, averaging 0.35 . Limnocrene and hillslope springs had somewhat lower geomorphic diversities, followed by helocrene, rheocrene, and hypocrene springs, which respectively had progressively lower geomorphic diversities.

\section{Solar Energy Budget and Rare Plants}

Aspect strongly influences springs vegetation composition, particularly at higher elevations (Stevens, 2012). Analyses of

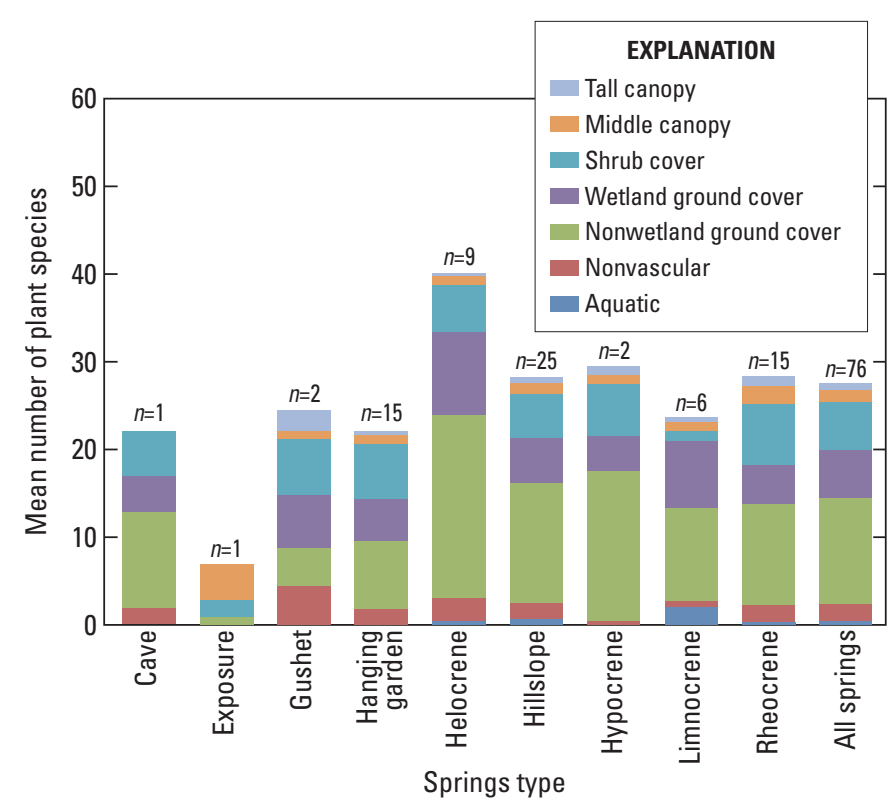

Figure 3. Chart showing native and nonnative plant species richness among nine springs types in Kaibab National Forest, northern Arizona (fig. 1). available solar radiation at the study sites indicated that hanging gardens, hillslope springs, gushets, and some rheocrene springs sustained substantially reduced solar radiation budgets owing to shading by adjacent cliffs. The first three of these springs types are known to support unusual, rare plant species, such as the populations of Primula specuicola we observed in Pasque and Solidago Hanging Gardens in the Sowats Creek drainage. Rheocrene springs are less likely to support rare plant species, owing to the frequency of flooding in those surface-flowdominated habitats. Although orchids may grow at helocrene and limnocrene springs, those springs types often are sunny and frequently disturbed by grazing; therefore they may be less likely to support shade-tolerant plant species.

\section{Vegetation}

We detected 441 plant species in the springs inventory during our 2010-2012 surveys and in data compiled from other sources. Plant species richness varied considerably among springs types (fig. 3). Exposure springs (which were rare and strongly influenced by human activities) had the lowest species richness, with only seven plant species per site, whereas marshforming helocrene springs had the highest species richness, with an average of 40 plant species per site. Rheocrene and hillslope springs and the sole hypocrene springs averaged a somewhat higher plant species richness than did gushet, limnocrene, hanging garden, or cave springs types.

Plant cover similarly varied considerably among springs types (fig. 4). Not surprisingly, the greatest percentage of aquatic vegetation cover occurred in pool-forming limnocrene springs, with only modest aquatic cover in other springs

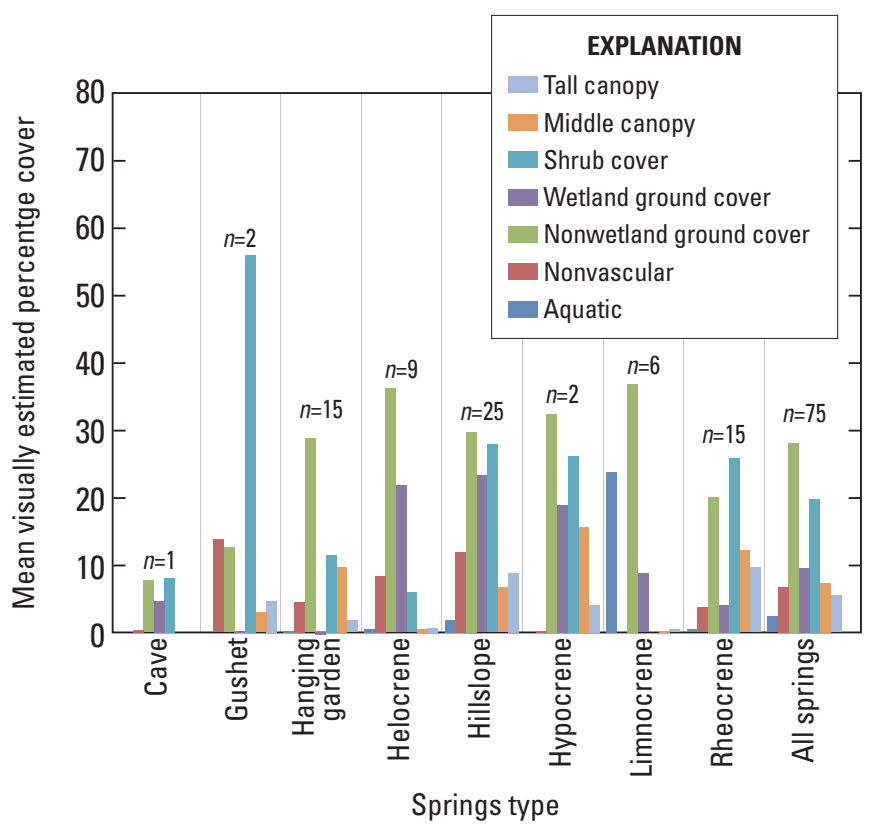

Figure 4. Chart showing mean visually estimated percentage cover of native and nonnative vegetation among eight springs types in Kaibab National Forest, northern Arizona (fig. 1). 
types. Mosses and other nonvascular taxa reached maximal cover at gushet and hillslope springs, somewhat less cover at helocrene springs, and little cover at other springs types. Native ground cover exceeded 30 percent at limnocrene, helocrene, and hypocrene springs and reached nearly that extent at hillslope and hanging garden springs. Scour and steep terrain limited native ground cover to slightly more than 20 percent at rheocrene and gushet springs. Nonnative ground cover exceeded 20 percent at hillslope and helocrene springs, averaging 9.5 percent across all springs types. Shrub cover vastly exceeded all other cover types at gushet springs, was $>25$ percent at hillslope, hypocrene, and rheocrene springs, and averaged 20 percent across all springs types. Middle and tall canopy cover was generally 10-20 percent at rheocrene, hypocrene, hillslope, and hanging garden springs, $<10$ percent at gushet springs, and very low at helocrene springs.

Kaibab National Forest is estimated to support $\sim 1,325$ plant taxa, for an overall average density of 0.002 plant species per hectare. Our surveys encompassed a total area of 6.01 ha of springs habitat, indicating that the plant species density at springs was 72.5 species per hectare. Although species-area constraints are responsible for much of this difference, we detected one-third of the entire flora in $<0.001$ percent of the forest landscape. These results attest to the remarkable concentration of plant species richness at springs in Kaibab National Forest.

\section{Invertebrates}

The richness and abundance of aquatic invertebrate species varied considerably among the array of springs in Kaibab National Forest. A total of 58 springs had sufficient flow to allow us to sample benthic invertebrates. We observed at least 410 aquatic, wetland, and riparian invertebrate morphospecies among 2,530 individual specimens collected. The North Canyon drainage is well known for supporting elevated numbers of unique or rare aquatic and riparian invertebrates, including at least five narrowly endemic taxa, as well as at least one undescribed stonefly (Plecoptera). However, other springs in the forest also support elevated densities of aquatic taxa, particularly Big Springs and those in the Sowats Creek drainage, all in the North Kaibab Ranger District. Few of the springs in the Williams Ranger District could be conclusively confirmed as perennial, a condition that limits the presence of many aquatic invertebrates. However, Big Springs in the Williams Ranger District may warrant more detailed entomological study because it supports at least two unusual aquatic beetle taxa, including Optioservus divergens (Elmidae) and an as-yet-unidentified scirtid marsh beetle.

The sum of Ephemeroptera, Plecoptera, and Trichoptera (the EPT score) in a sample is a commonly used water quality metric (table 3; Lenat, 1988). EPT scores at springs in Kaibab National Forest were weakly positively related to perennial spring elevation, discharge, and $\mathrm{pH}$, and were weakly negatively related to specific conductance and water temperature, with $R^{2}$ values ranging from 0.013 to 0.36 . EPT species vary widely in their tolerance of water quality. Nonetheless, the slightly negative relationship between specific conductance and water temperature may partly explain the relatively high concentrations of flatworms, stoneflies, and other aquatic invertebrate species in upper elevation, cool, low-solute springs, such as those in the North Canyon drainage, and the limited presence of those taxa at middle- and low-elevation, warmer springs with elevated solute concentrations.

\section{Vertebrates}

We detected a wide array of vertebrates during our springs inventory of Kaibab National Forest; however, the list of vertebrates is incomplete for any individual springs ecosystem. Such a list would require a focused study of vertebrate habitat use, which was beyond the scope of the present effort. Surveyors observed only a few herpetofaunae, including tiger salamander (Ambystoma tigrinum) and wandering garter snake (Thamnophis elegans). They reported a wide array of woodpecker, raptor, and songbird species; and mammals, ranging from pocket gophers (Thomomys) to ungulates and predators. Among the mammals, four introduced taxa directly impact springs. In addition to cattle and sheep, nonnative Rocky Mountain elk (Cervus elaphus) are abundant in the Williams Ranger District, and evidence of elk browsing and trampling is ubiquitous in springs wetland habitats. Small numbers of elk also have reportedly colonized the North Kaibab Ranger District, but we did not detect elk impacts on springs there. We observed signs of introduced bison at several sites in the North Kaibab Ranger District, particularly around natural ponds. The bison population is reportedly expanding, and their wallowing, trampling, and grazing may adversely affect wetlands in the North Kaibab Ranger District.

\section{Assessment of Springs Ecosystem Integrity}

We used the SSI SEAP to evaluate the ecologic integrity of and risks to natural resources, human influences and risks, and the administrative context of 86 of the springs inventoried in Kaibab National Forest (table 4). We first examined the array of human impacts on springs between the two larger districts. This analysis demonstrated that adjacent forest conditions, flow regulation, and herbivores affected springs the most, with differences in the form and extent of impact between the North Kaibab and Williams Ranger Districts. Springs in the North Kaibab Ranger District have sustained less intensive human use and typically are in slightly better ecologic condition than those in the Williams Ranger District. Many springs in the North Kaibab Ranger District lie within wilderness areas and (or) are in areas that are difficult to access, and so they are buffered from some direct human uses. Increased impacts from flow regulation, herbivory, and adjacent land uses are more likely to affect surface water 
Table 3. Selected springs in Kaibab National Forest that support elevated key aquatic indicator taxon species richness.

[Ranger district: N, North Kaibab; W, Williams. Asterisk (*), springs that support both Plecoptera and Turbellaria]

\begin{tabular}{|c|c|c|c|c|c|c|c|c|c|c|c|}
\hline \multirow[b]{2}{*}{ Spring } & \multirow{2}{*}{$\begin{array}{l}\text { Ranger } \\
\text { district }\end{array}$} & \multicolumn{7}{|c|}{ Taxa } & \multirow{2}{*}{$\begin{array}{c}E / P / T \\
\text { taxon } \\
\text { sum }\end{array}$} & \multirow{2}{*}{$\begin{array}{l}\text { Minimum } \\
\text { total number } \\
\text { of taxa }\end{array}$} & \multirow{2}{*}{$\begin{array}{l}\text { Number of } \\
\text { individuals } \\
\text { specimens }\end{array}$} \\
\hline & & $\begin{array}{l}\text { Ephemerop- } \\
\text { tera }\end{array}$ & $\begin{array}{l}\text { Plecop- } \\
\text { tera }\end{array}$ & $\begin{array}{c}\text { Trichop- } \\
\text { tera }\end{array}$ & Coleoptera & Diptera & Odonata & Turbellaria & & & \\
\hline Aconitum* & $\mathrm{N}$ & 1 & 1 & 2 & 2 & 2 & 0 & 1 & 4 & 14 & 33 \\
\hline Bear & $\mathrm{N}$ & 1 & 0 & 1 & 2 & 2 & 2 & 0 & 2 & 18 & 27 \\
\hline Big (North Kaibab RD)* & $\mathrm{N}$ & 3 & 4 & 11 & 17 & 7 & 8 & 1 & 18 & 128 & 279 \\
\hline Big (Williams RD) & W & 0 & 0 & 1 & 5 & 1 & 3 & 0 & 1 & 22 & 27 \\
\hline Bitter & $\mathrm{N}$ & 1 & 0 & 0 & 2 & 1 & 0 & 0 & 1 & 3 & 3 \\
\hline Castle & $\mathrm{N}$ & 0 & 0 & 1 & 1 & 5 & 0 & 1 & 1 & 35 & 67 \\
\hline Coconino Fracture* & $\mathrm{N}$ & 0 & 1 & 1 & 3 & 1 & 0 & 1 & 2 & 10 & 18 \\
\hline Cottonwood Cienega & $\mathrm{N}$ & 1 & 0 & 0 & 0 & 0 & 1 & 0 & 1 & 2 & 2 \\
\hline Cottonwood & $\mathrm{N}$ & 1 & 0 & 0 & 0 & 1 & 0 & 0 & 1 & 2 & 2 \\
\hline Crane Lake & $\mathrm{N}$ & 0 & 0 & 1 & 8 & 11 & 6 & 0 & 1 & 50 & 107 \\
\hline Crystal & $\mathrm{N}$ & 0 & 0 & 4 & 3 & 7 & 1 & 1 & 4 & 24 & 101 \\
\hline Dead Fawn* & $\mathrm{N}$ & 0 & 2 & 1 & 4 & 4 & 0 & 1 & 3 & 20 & 44 \\
\hline Dog Lake & $\mathrm{N}$ & 0 & 0 & 1 & 10 & 7 & 4 & 1 & 1 & 40 & 116 \\
\hline Dry Park Lake & $\mathrm{N}$ & 0 & 0 & 1 & 0 & 1 & 3 & 0 & 1 & 7 & 26 \\
\hline Elsie & W & 1 & 0 & 0 & 7 & 2 & 7 & 0 & 1 & 29 & 50 \\
\hline Glenn Rink* & $\mathrm{N}$ & 1 & 1 & 1 & 6 & 5 & 0 & 1 & 3 & 29 & 76 \\
\hline Hat Tank Lower & W & 1 & 0 & 2 & 6 & 5 & 4 & 0 & 3 & 38 & 58 \\
\hline Jumpup & $\mathrm{N}$ & 1 & 0 & 0 & 4 & 4 & 2 & 0 & 1 & 13 & 18 \\
\hline Lookout Lakes & $\mathrm{N}$ & 0 & 0 & 1 & 6 & 3 & 5 & 0 & 1 & 45 & 70 \\
\hline Lower Jumpup Below & $\mathrm{N}$ & 1 & 0 & 0 & 10 & 3 & 2 & 0 & 1 & 20 & 27 \\
\hline Lower Sowats Seep & $\mathrm{N}$ & 0 & 0 & 1 & 1 & 0 & 0 & 0 & 1 & 3 & 3 \\
\hline Mangum $^{1}$ & $\mathrm{~N}$ & 0 & 1 & 0 & 1 & 2 & 0 & 0 & 1 & 8 & 8 \\
\hline Mangum * & $\mathrm{N}$ & 0 & 2 & 1 & 2 & 6 & 0 & 1 & 3 & 22 & 31 \\
\hline McDermit & W & 1 & 0 & 0 & 5 & 2 & 0 & 0 & 1 & 14 & 32 \\
\hline Mountain Sheep & $\mathrm{N}$ & 1 & 0 & 0 & 18 & 6 & 4 & 0 & 1 & 40 & 53 \\
\hline North Canyon Lower & $\mathrm{N}$ & 1 & 1 & 4 & 1 & 1 & 0 & 0 & 6 & 9 & 9 \\
\hline North Canyon Middle* & $\mathrm{N}$ & 1 & 2 & 5 & 4 & 3 & 0 & 0 & 8 & 42 & 79 \\
\hline North Canyon Upper & $\mathrm{N}$ & 0 & 1 & 3 & 1 & 3 & 0 & 0 & 4 & 27 & 46 \\
\hline Oak & $\mathrm{N}$ & 0 & 0 & 2 & 5 & 3 & 1 & 0 & 2 & 22 & 30 \\
\hline Pasture & $\mathrm{N}$ & 0 & 1 & 3 & 1 & 2 & 0 & 0 & 4 & 8 & 10 \\
\hline Pipe Camp Navajo & W & 1 & 0 & 1 & 8 & 4 & 3 & 0 & 2 & 33 & 59 \\
\hline Riggs Tank & $\mathrm{N}$ & 0 & 0 & 1 & 3 & 6 & 0 & 0 & 1 & 20 & 29 \\
\hline South Canyon & $\mathrm{N}$ & 0 & 0 & 2 & 3 & 1 & 0 & 0 & 2 & 8 & 13 \\
\hline Sowats & $\mathrm{N}$ & 2 & 0 & 2 & 3 & 1 & 1 & 1 & 4 & 19 & 33 \\
\hline Sowats Upper & $\mathrm{N}$ & 0 & 0 & 2 & 6 & 3 & 0 & 0 & 2 & 28 & 42 \\
\hline Sowats Veronica & $\mathrm{N}$ & 1 & 0 & 2 & 5 & 2 & 2 & 1 & 3 & 27 & 45 \\
\hline Stonefly & $\mathrm{N}$ & 0 & 1 & 1 & 0 & 1 & 0 & 0 & 2 & 4 & 5 \\
\hline Table Rock & $\mathrm{N}$ & 1 & 0 & 0 & 0 & 5 & 0 & 0 & 1 & 13 & 21 \\
\hline Tappen & W & 1 & 0 & 0 & 6 & 1 & 6 & 0 & 1 & 26 & 36 \\
\hline Tater Canyon Upper & $\mathrm{N}$ & 0 & 0 & 1 & 0 & 1 & 0 & 0 & 1 & 2 & 2 \\
\hline Timp & $\mathrm{N}$ & 1 & 0 & 1 & 0 & 4 & 0 & 0 & 2 & 11 & 36 \\
\hline VT Lake & $\mathrm{N}$ & 0 & 0 & 2 & 4 & 6 & 5 & 1 & 2 & 30 & 40 \\
\hline Watts & $\mathrm{N}$ & 0 & 0 & 2 & 2 & 2 & 0 & 0 & 2 & 10 & 14 \\
\hline
\end{tabular}


quality in the Williams Ranger District. Grazing is likely to exert stronger impacts on higher elevation sites owing to the shorter growing season and, therefore, reduced recovery time (for example, Samuelson and Rood, 2011).

We plotted the overall scores for natural resource conditions of each springs ecosystem for which SEAP data were available against the human risk category score for that site. Using resource condition values of 3 (moderate ecologic condition or value) and human risk scores of 3 (moderate risk but moderate rehabilitation potential) as midpoints, we identified springs in and near the upper right quadrant of the graph that have high natural resource value but are at risk from human impacts (fig. 5). This graphic approach indicated springs in the two larger ranger districts that may warrant further investigation and (or) management attention. Those springs in the Williams Ranger District that ranked highest in this regard include Lockett, Tappan, Pipe, and Mud, with Rosilda and McDermit (fig. $5 A$ ). Springs in the North Kaibab Ranger District that ranked highest in priority for management attention included Big Springs, Crystal, Pigeon, Table Rock, Pasture, and Castle (fig. 5B). Management needs range from simple construction of a steppingstone access trail to the source (for example, at Big Springs in the North Kaibab Ranger District), to potential geomorphic rehabilitation (for example, Mud and Rosilda Springs in the Williams Ranger District). Three common management recommendations involved (1) fencing springs to protect the sources from livestock impacts, while providing for springs flow downstream; (2) removing unnecessary springs boxes and piping; and (3) maintenance of existing flow-regulation structures and piping, where such infrastructure is needed. Specific management recommendations were included in the reports on each inventoried springs ecosystem.

\section{Discussion and Management Considerations}

The springs in Kaibab National Forest are abundant but generally small ecosystems that support a wide array of physical, biological, and cultural/socioeconomic resources. Extrapolating the average habitat area of measured springs to the 205 known springs in Kaibab National Forest suggests that the total area of springs habitat in the forest is approximately 15 ha. Although additional springs remain undocumented, particularly along the Coconino SandstoneHermit Shale contact in the headwaters of Kanab Creek, the overall habitat area of springs is unlikely to exceed 20 ha. Similar extrapolation of flow data from the group of 75 springs with adequate flow-measurement data to the 205 total known springs, including the maximum flow from North Kaibab Big Springs (12.3 L/s), gives an estimated total springs discharge of $40 \mathrm{~L} / \mathrm{s}$.

In addition to surface flows from the North Kaibab Ranger District, a substantial but less well monitored flow $(\sim 2,500 \mathrm{~L} / \mathrm{s})$ emerges as cool- or cold-water springs from the Redwall/Muav Aquifer in Tapeats, Deer, Shinumo, and Bright Angel Creeks and from the Upper Marble Canyon springs complex near Vaseys Paradise on the north side of the Colorado River in Grand Canyon National Park. These aquifers underlie some or much of the North Kaibab Ranger District. Also, the deep-aquifer Blue Springs complex in the lower Little Colorado River drainage and Havasu Springs in Cataract/Havasu Creek on the east and south sides of the Grand Canyon, respectively, as well as other small tributaries, contribute another $\sim 7,500 \mathrm{~L} / \mathrm{s}$ (Kreamer and Springer, 2008). Kaibab National Forest overlies a substantial portion of the regional perched aquifers, which discharge approximately 10 cubic meters per second $\left(\mathrm{m}^{3} / \mathrm{s}\right)$ of springs flow into the Colorado River in the Grand Canyon. Analysis of pre- and post-dam flows of the Colorado River at Lees Ferry, immediately upstream from the Grand Canyon, reveal that autumn and winter average monthly minimum

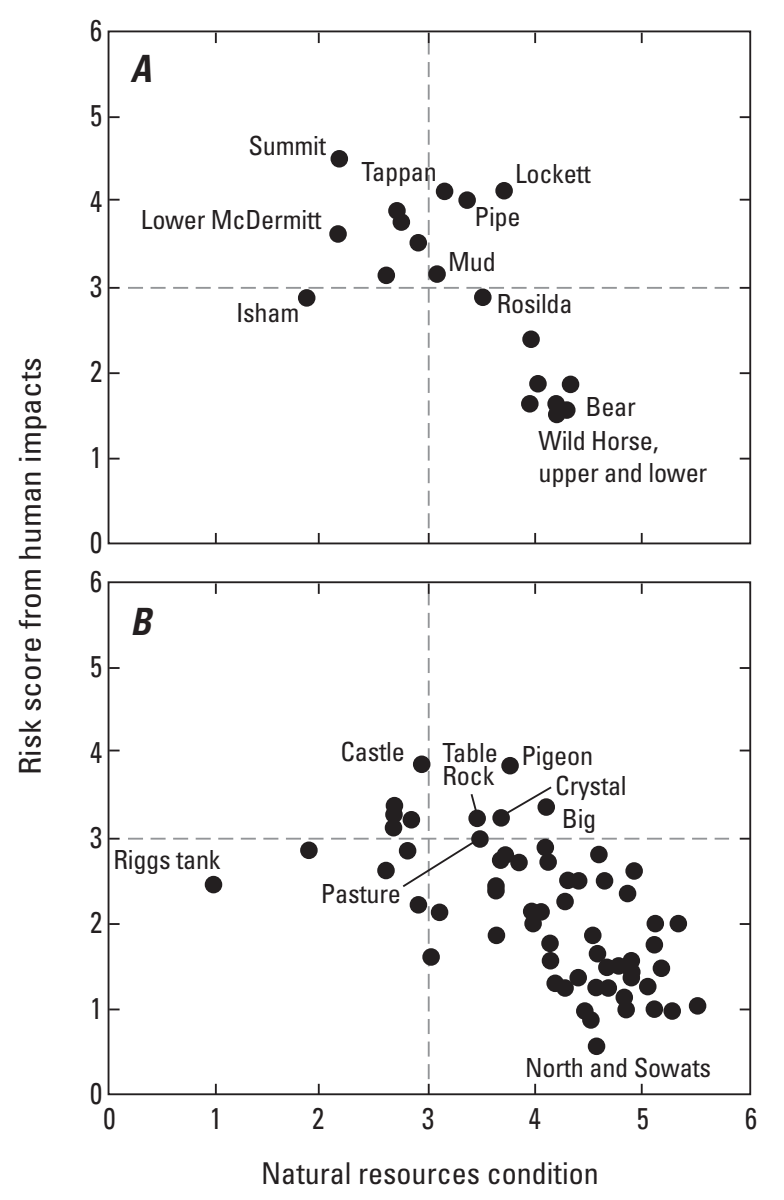

Figure 5. Plots of stewardship risks to springs from human impacts in relation to overall score for natural resources condition in the Williams Ranger District $(A)$ and the North Kaibab Ranger District (B) in Kaibab National Forest, northern Arizona (fig. 1). Springs in upper right quadrant may warrant management attention. 
Table 4. Springs ecosystem assessment category condition and risk scores, overall natural resource condition and risk score, and null scores.

[Locations: NC, central North Kaibab Ranger District; NE, east side of North Kaibab Ranger District; NW, west side of North Kaibab Ranger District; RD, ranger district; S, Williams Ranger District. Spring types: C, cienega/helocrene/springfed fen; G, gushet; H, hillslope; HG, hanging garden; L, limnocrene; LGC, low-gradient cienega; R, rheocrene. Aquifers: B, neogene basalt; C, Coconino; H, Hermit Shale; K, Kaibab; Su, Supai; T, Toroweap Formation. Estimated scores are in bold]

\begin{tabular}{|c|c|c|c|c|c|c|c|c|c|c|c|c|c|c|c|c|c|}
\hline \multirow{2}{*}{ Spring } & \multirow{2}{*}{$\begin{array}{l}\text { Location- } \\
\text { type- } \\
\text { aquifer }\end{array}$} & \multicolumn{2}{|c|}{$\begin{array}{c}\text { Aquifer } \\
\text { functionality } \\
\text { water quality }\end{array}$} & \multicolumn{2}{|c|}{$\begin{array}{l}\text { Geomorph- } \\
\text { ology }\end{array}$} & \multicolumn{2}{|c|}{ Habitat } & \multicolumn{2}{|c|}{$\begin{array}{l}\text { Biotic } \\
\text { integrity }\end{array}$} & \multicolumn{2}{|c|}{$\begin{array}{l}\text { Natural } \\
\text { resource }\end{array}$} & \multicolumn{2}{|c|}{$\begin{array}{l}\text { Freedom from } \\
\text { human impact }\end{array}$} & \multicolumn{2}{|c|}{$\begin{array}{l}\text { Administra- } \\
\text { tive context }\end{array}$} & \multicolumn{2}{|c|}{ Null } \\
\hline & & Score & $\begin{array}{c}\text { Risk } \\
\text { score }\end{array}$ & Score & $\begin{array}{c}\text { Risk } \\
\text { score }\end{array}$ & Score & \begin{tabular}{|c|} 
Risk \\
score
\end{tabular} & Score & \begin{tabular}{|c|} 
Risk \\
score
\end{tabular} & Score & \begin{tabular}{|c|} 
Risk \\
score
\end{tabular} & Score & $\begin{array}{c}\text { Risk } \\
\text { score }\end{array}$ & Score & \begin{tabular}{|c|} 
Risk \\
score
\end{tabular} & Score & $\begin{array}{l}\text { Risk } \\
\text { score }\end{array}$ \\
\hline 27 Mule & NW-R-H & 4 & 1.7 & 4 & 2 & 3.8 & 2.6 & 4.9 & 2.3 & 4.2 & 2.1 & 4.9 & 1.6 & 2.8 & 2.4 & 0 & 0 \\
\hline Acer & NW-H-H & 4 & 2 & 4.2 & 1.2 & 4 & 1.6 & 4.6 & 1.4 & 4.2 & 1.5 & 5 & 1.3 & 2.7 & 2 & 1 & 0 \\
\hline Aconitum & NC-HG-C & 4.8 & 1 & 4.6 & 2 & 5.4 & 1.8 & 5 & 1.8 & 5 & 1.6 & 5.5 & 1.4 & 4.3 & 3 & 2 & 4 \\
\hline Bear & NW-R-K & 4.5 & 1.8 & 5.2 & 3 & 5.5 & 2.3 & 4.5 & 3 & 4.9 & 2.5 & 4.6 & 2.6 & 3.4 & 1.9 & 33 & 33 \\
\hline Bear & S-R-B & 4.2 & 1.2 & 4.2 & 1.2 & 4.2 & 1.6 & 4.3 & 1.9 & 4.2 & 1.5 & 4.2 & 1.5 & 3.9 & 2.4 & 0 & 1 \\
\hline Bear Lake & NC-L-K & 4.2 & 2 & 4.8 & 2.2 & 4.2 & 2.2 & 4.1 & 2.4 & 4.3 & 2.2 & 4.3 & 2.5 & 4 & 2.4 & 2 & 1 \\
\hline Bee & NC-H-K & 2.2 & 4.5 & 1 & 4.4 & 2 & 4.8 & 2.4 & 4.3 & 1.9 & 4.5 & 3 & 2.9 & 3.7 & 2.1 & 0 & 1 \\
\hline Big (North Kaibab RD) & NW-HG-C & 4.8 & 1.7 & 3.2 & 3.8 & 4 & 4 & 4.4 & 3.4 & 4.1 & 3.2 & 3.9 & 3.4 & 4.4 & 2.7 & 0 & 0 \\
\hline Big (Williams RD) & S-H-B & 4 & 3.2 & 4.6 & 2.2 & 4 & 2.8 & 3.3 & 3.1 & 4 & 2.8 & 3.9 & 2.4 & 4.9 & 2.4 & 1 & 1 \\
\hline Boulder & NW-R-H & 5.3 & 0.8 & 4.6 & 0.8 & 3.2 & 1.8 & 4 & 2.6 & 4.3 & 1.5 & 4.9 & 1.3 & 2.7 & 1.9 & 0 & 1 \\
\hline Buck & S-M-B & 2 & 4.2 & 2.6 & 3.6 & 3.6 & 3.2 & 2.8 & 4 & 2.7 & 3.7 & 2.8 & 3.8 & 4.4 & 3.1 & 2 & 1 \\
\hline Burro & NE-L-T & 5 & 1.4 & 4.6 & 1 & 4.3 & 1.6 & 4.8 & 2.5 & 4.7 & 1.6 & 4.2 & 2.5 & 3.4 & 2 & 3 & 1 \\
\hline Cane Aqueduct & NE-H-C & 4.5 & 1.8 & 2.8 & 3.6 & 3.4 & 3.2 & 4.3 & 3.1 & 3.8 & 2.9 & 3.7 & 2.8 & 3.6 & 2.8 & 0 & 1 \\
\hline Castle & NC-HG-C & 3.8 & 2.3 & 2.6 & 4.2 & 3.2 & 3.2 & 2.1 & 4.1 & 2.9 & 3.5 & 2.7 & 3.9 & 3.1 & 3 & 2 & 3 \\
\hline Coconino Fracture & NC-G-T & 5.2 & 1 & 5.4 & 1 & 4.4 & 1.6 & 5.5 & 1.3 & 5.1 & 1.2 & 5.2 & 1 & 3.4 & 2.3 & 9 & 9 \\
\hline Crane Lake & NC-L-K & 3.6 & 3 & 3.3 & 3.3 & 4 & 2.4 & 3.8 & 3.5 & 3.7 & 3 & 4.3 & 2.4 & 4.3 & 2.3 & 2 & 2 \\
\hline Crystal & NC-H-K & 4 & 1.5 & 3.6 & 3.4 & 3.2 & 3.4 & 4 & 3 & 3.7 & 2.8 & 3.9 & 3.3 & 3.4 & 2.3 & 9 & 9 \\
\hline Dead Fawn & NC-R-K & 5 & 1 & 5.2 & 0.8 & 4.2 & 1.4 & 5 & 1.4 & 4.9 & 1.1 & 5.1 & 1 & 2.6 & 1.9 & 1 & 2 \\
\hline Deer Lake & NC-L-K & 5.6 & 2 & 4 & 2.5 & 4.2 & 3.2 & 4.6 & 3.1 & 4.6 & 2.7 & 2.4 & 2.8 & 3.7 & 2.1 & 2 & 2 \\
\hline Dog Lake & NC-L-K & 4.2 & 2.3 & 1.8 & 5 & 2 & 4.6 & 3.3 & 4.3 & 2.8 & 4 & 3.1 & 2.9 & 3.9 & 2 & 1 & 1 \\
\hline Dry Park Lake & NC-L-K & 4.3 & 1.6 & 3 & 2.8 & 3.6 & 2.8 & 3.9 & 3.1 & 3.7 & 2.6 & 3.6 & 2.8 & 3.8 & 2.1 & 3 & 3 \\
\hline Elsie & S-He-K & 2.8 & 3.2 & 2.3 & 4 & 3,4 & 4 & 3.6 & 3.4 & 2.9 & 3.7 & 3.4 & 3.5 & 4.2 & 2.1 & 1 & 1 \\
\hline Franks Lake & NC-L-K & 5 & 2 & 5 & 2 & 6 & 2 & 3.5 & 2 & 4.9 & 2 & 5.1 & 1.6 & - & - & 24 & 23 \\
\hline Glenn Rink & NC-H-T & 5.5 & 2 & 5.2 & 1.8 & 4.6 & 1.8 & 5.4 & 1.6 & 5.2 & 1.8 & 5.3 & 1.5 & 3.4 & 2.3 & 9 & 9 \\
\hline Hat Tank Lower & S-R-B & 4 & 2 & 4.2 & 2.6 & 3.8 & 2.6 & 3.9 & 3 & 4 & 2.6 & 4.6 & 1.6 & 3.7 & 2.5 & 1 & 1 \\
\hline Hat Tank Upper & S-R-K & 4.2 & 1.8 & 3.6 & 2.8 & 3.8 & 3 & 4.5 & 2.1 & 4 & 2.4 & 4.4 & 1.9 & 3.9 & 3.4 & 0 & 1 \\
\hline Isham & S-H-Dry & 0 & 6 & 1.6 & 4.4 & 2.2 & 4.6 & 3.6 & 4 & 1.9 & 4.8 & 3 & 2.9 & 3.7 & 2.3 & 0 & 1 \\
\hline Jumpup & NW-HG-C & 3.8 & 2.6 & 4.8 & 1.2 & 4.8 & 1.6 & 4.8 & 1.3 & 4.5 & 1.7 & 4.6 & 1.9 & 4.2 & 2.5 & 1 & 2 \\
\hline Little & NW-R-T & 5 & 0.8 & 4.8 & 1.4 & 4.2 & 1.8 & 4.4 & 2.3 & 4.6 & 1.6 & 4.9 & 1.6 & 3.9 & 2.1 & 0 & 1 \\
\hline Little Willow & NW-R-H & 4.7 & 0.7 & 5 & 0.4 & 4 & 1 & 4.6 & 2 & 4.6 & 1 & 4.9 & 1.3 & 3.3 & 1.6 & 0 & 1 \\
\hline Lockett & S-LGC-K & 3.3 & 3.6 & 2.8 & 4.8 & 4.8 & 2.7 & 3.9 & 3.3 & 3.7 & 3.6 & 3 & 4.1 & 4.7 & 2.8 & 0 & 5 \\
\hline Locust & NW-M-K & 4 & 1.8 & 2.8 & 5 & 2 & 5 & 2.5 & 5 & 2.8 & 4.2 & 3.8 & 3.3 & 3.3 & 2.3 & 7 & 6 \\
\hline Lookout Lakes & NC-L-K & 5.3 & 1.5 & 4 & 3 & 4.2 & 3 & 4.1 & 3.6 & 4.4 & 2.8 & 3.8 & 2.5 & 3.4 & 2 & 4 & 4 \\
\hline Lower McDermit & S-H-B & 1.2 & 5 & 1.4 & 4.6 & 3.2 & 4.2 & 2.9 & 4 & 2.2 & 4.5 & 2.8 & 3.6 & 3.7 & 2.3 & 0 & 1 \\
\hline Lower Sowats Seep & NW-HG-Su & 4.3 & 1.3 & 6 & 1 & 5.2 & 2 & 5 & 2.3 & 5.1 & 1.6 & 5.3 & 1.8 & 3.6 & 1.6 & 6 & 5 \\
\hline Mangum & NW-HG-C & 3.5 & 1.8 & 3.2 & 3 & 2.4 & 3.8 & 3 & 2.8 & 3 & 2.8 & 4.2 & 1.6 & 4.3 & 1.9 & 0 & 1 \\
\hline Mangum 1 & NW-HG-C & 4.5 & 1.2 & 3 & 3.8 & 3.2 & 4 & 3.9 & 2.9 & 3.6 & 3 & 4 & 1.9 & 4.2 & 1.9 & 0 & 1 \\
\hline Mangum 6 & NW-HG-C & 4 & 2 & 4 & 1 & 4.8 & 1.2 & 5 & 2 & 4.5 & 1.6 & 5.8 & 1 & 4.4 & 1.8 & 11 & 12 \\
\hline Mangum 7 & NW-HG-C & 4.8 & 1 & 3.6 & 2.2 & 4 & 2.6 & 4.1 & 2 & 4.1 & 2 & 4.4 & 1.8 & 4 & 2.3 & 24 & 25 \\
\hline McDermit & S-M-K & 3 & 3.3 & 1.4 & 4.6 & 3.8 & 2.6 & 2.6 & 4.1 & 2.7 & 3.7 & 2.8 & 3.9 & 3.7 & 2.3 & 9 & 9 \\
\hline Mountain Sheep & NW-H-S & 4.8 & 2.8 & 5.2 & 1.6 & 4.2 & 2.2 & 5.3 & 1.9 & 4.9 & 2.1 & 4.7 & 2.4 & 4.5 & 2.1 & 1 & 1 \\
\hline
\end{tabular}


Table 4.-Continued

\begin{tabular}{|c|c|c|c|c|c|c|c|c|c|c|c|c|c|c|c|c|c|}
\hline \multirow[t]{2}{*}{ Spring } & \multirow{2}{*}{$\begin{array}{l}\text { Location- } \\
\text { type- } \\
\text { aquifer }\end{array}$} & \multicolumn{2}{|c|}{$\begin{array}{c}\text { Aquifer } \\
\text { functionality } \\
\text { water quality }\end{array}$} & \multicolumn{2}{|c|}{$\begin{array}{l}\text { Geomorph- } \\
\text { ology }\end{array}$} & \multicolumn{2}{|c|}{ Habitat } & \multicolumn{2}{|c|}{$\begin{array}{l}\text { Biotic } \\
\text { integrity }\end{array}$} & \multicolumn{2}{|c|}{$\begin{array}{l}\text { Natural } \\
\text { resource }\end{array}$} & \multicolumn{2}{|c|}{$\begin{array}{l}\text { Freedom from } \\
\text { human impact }\end{array}$} & \multicolumn{2}{|c|}{$\begin{array}{l}\text { Administra- } \\
\text { tive context }\end{array}$} & \multicolumn{2}{|c|}{ Null } \\
\hline & & Score & $\begin{array}{l}\text { Risk } \\
\text { score }\end{array}$ & Score & \begin{tabular}{|l|} 
Risk \\
score
\end{tabular} & Score & \begin{tabular}{|l} 
Risk \\
score
\end{tabular} & Score & \begin{tabular}{c|} 
Risk \\
score
\end{tabular} & Score & $\begin{array}{l}\text { Risk } \\
\text { score }\end{array}$ & Score & \begin{tabular}{|c|} 
Risk \\
score
\end{tabular} & Score & \begin{tabular}{|c|} 
Risk \\
score
\end{tabular} & Score & $\begin{array}{c}\text { Risk } \\
\text { score }\end{array}$ \\
\hline Mud & S-M-B & 3.2 & 1.5 & 3 & 2.8 & 3.4 & 3.6 & 2.8 & 3.8 & 3.1 & 2.9 & 3.2 & 3.1 & 4.1 & 2.4 & 1 & 1 \\
\hline North Canyon Lower & NC-H-T & 5.3 & 0.8 & 5.2 & 1.2 & 5.8 & 1.2 & 5.8 & 1.4 & 5.5 & 1.2 & 5.5 & 1 & 3.2 & 2.3 & 0 & 1 \\
\hline North Canyon Middle & NC-H-T & 5 & 1 & 4.6 & 1.6 & 5.4 & 1.8 & 5.8 & 1.3 & 5.2 & 1.4 & 5.3 & 1.5 & 3.4 & 2.3 & 0 & 1 \\
\hline North Canyon Upper & NC-H-T & 5 & 0.8 & 4.8 & 1.2 & 5.8 & 1.2 & 5.5 & 1.4 & 5.3 & 1.2 & 5.5 & 1 & 3.2 & 2.3 & 0 & 1 \\
\hline Oak & NW-H-T & 3.8 & 2 & 1.8 & 4.8 & 3.4 & 3.8 & 3.5 & 3.4 & 3.1 & 3.5 & 4.3 & 2.1 & 3.5 & 2.5 & 8 & 9 \\
\hline Oquer & NW-H-K & 4.5 & 1.8 & 3 & 2.4 & 3.6 & 2.4 & 3.5 & 2 & 3.7 & 2.2 & 3.1 & 2.4 & 3.3 & 2.1 & 1 & 2 \\
\hline Parissawampitts & NW-M-K & 3.4 & 3.2 & 2.2 & 3 & 2.4 & 3.2 & 2.8 & 3 & 2.7 & 3.1 & 2.3 & 3.3 & 3.9 & 2 & 6 & 7 \\
\hline Pasque & NW-HG-C & 4.7 & 1 & 5.2 & 1 & 4.4 & 1.2 & 5.3 & 1 & 4.9 & 1.1 & 5.2 & 1.5 & 2.7 & 1.9 & 0 & 1 \\
\hline Pasture & NW-H-K & 3.6 & 3 & 3.4 & 3 & 4.3 & 3 & 2.8 & 3 & 3.5 & 3 & 4.4 & 3 & - & - & 16 & 16 \\
\hline Phragmites & NW-Hy-H & 3.2 & 1 & 4.2 & 2.2 & 3.8 & 2 & 4.8 & 2 & 4 & 1.8 & 4 & 2 & 2.7 & 1.9 & 0 & 1 \\
\hline Pigeon & NW-HG-T & 4.5 & 2 & 3.2 & 3.2 & 3.6 & 3.2 & 3.8 & 3.1 & 3.8 & 2.9 & 3.2 & 3.9 & 3.9 & 2.6 & 0 & 1 \\
\hline Pipe Camp Navajo & S-LGC-K & 4 & 3.2 & 2.3 & 4.2 & 3.6 & 4.2 & 3.5 & 3.6 & 3.4 & 3.8 & 3.6 & 4 & 4.3 & 2.2 & 1 & 0 \\
\hline Quaking Aspen & NE-C-K & 3.8 & 3 & 3.4 & 3 & 4.4 & 3 & 3.3 & 3 & 3.7 & 3 & 3.7 & 2.7 & 3.9 & 2.1 & 6 & 7 \\
\hline Riggs Tank & NE-C-K & 3.2 & 3 & 0 & 6 & 0.8 & 5.2 & 0 & 6 & 1 & 5.1 & 3.5 & 2.5 & 3.8 & 2 & 11 & 11 \\
\hline Rock Lower & NW-HG-M & 4.5 & 2.7 & 3.4 & 3 & 3.8 & 2.8 & 4.8 & 2.5 & 4.1 & 2.7 & 3.9 & 2.8 & 4 & 2 & 1 & 1 \\
\hline Rock Upper Bowl & NW-HG-M & 4 & 2.7 & 4.6 & 2 & 3.4 & 3 & 4.3 & 3.3 & 4.1 & 2.7 & 4.4 & 2.1 & 2.9 & 2.3 & 0 & 1 \\
\hline Rocky Tule & S-H-B & 3.8 & 3.2 & 1.5 & 3 & 2.3 & 2.8 & 2.8 & 3 & 2.6 & 3 & 2 & 3.1 & - & - & 35 & 34 \\
\hline Rosilda & S-R-K & 3.3 & 2.2 & 3 & 2.8 & 3.8 & 3 & 3.9 & 2.8 & 3.5 & 2.7 & 3.6 & 2.9 & 3.7 & 2.5 & 0 & 1 \\
\hline Slide & NW-R-T & 4.5 & 1.8 & 4.6 & 1 & 4 & 1.2 & 4.1 & 2.1 & 4.3 & 1.5 & 3.8 & 2.3 & 3.8 & 2.3 & 0 & 1 \\
\hline Solidago & NW-HG-C & 4.7 & 1.2 & 5.2 & 1 & 4.2 & 1.4 & 5.1 & 1.1 & 4.8 & 1.2 & 5.2 & 1.5 & 2.7 & 1.9 & 0 & 1 \\
\hline South Canyon & NC-R-C & 3.2 & 3.4 & 4 & 3.2 & 4.3 & 2.8 & - & - & 3.8 & 3.1 & 3.7 & 2.7 & 3.9 & 2.6 & 11 & 12 \\
\hline Sowats & NW-H-T & 4.7 & 1 & 5 & 1.2 & 4 & 2.6 & 4.7 & 2 & 4.6 & 1.7 & 5.6 & 0.6 & 3.1 & 1.9 & 7 & 8 \\
\hline Sowats Middle & NW-H-T & 4.7 & 1 & 5 & 0.6 & 5 & 1.2 & 4.9 & 1.4 & 4.9 & 1 & 4.8 & 1.4 & 3.1 & 1.1 & 1 & 1 \\
\hline Sowats Upper & NW-HG-T & 4.2 & 1 & 4.8 & 1.8 & 3.8 & 2 & 4.9 & 2 & 4.4 & 1.7 & 4.9 & 1.4 & 3.4 & 1.6 & 1 & 3 \\
\hline Sowats Veronica & NW-H-T & 5 & 1 & 4.8 & 1.8 & 4 & 1.4 & 4.9 & 2 & 4.7 & 1.6 & 4.8 & 1.5 & 4 & 1.9 & 0 & 1 \\
\hline Stonefly & NC-R-K & 4.8 & 1 & 5.4 & 1 & 4 & 1.4 & 5.1 & 1.8 & 4.8 & 1.3 & 5 & 1.1 & 2.7 & 1.9 & 0 & 1 \\
\hline Summit & S-H-B & 1 & 5 & 2.2 & 4.2 & 2.6 & 3.8 & 2.8 & 3.8 & 2.1 & 4.2 & 2 & 4.5 & 3 & 4 & 12 & 8 \\
\hline Table Rock & NW-HG-T & 4.3 & 1.2 & 2.2 & 4.8 & 3.6 & 4.4 & 3.8 & 3.1 & 3.5 & 3.4 & 3.4 & 3.3 & 4 & 2.1 & 0 & 1 \\
\hline Tappan & S-He-K & 4.4 & 2.4 & 2 & 5 & 3.2 & 4.6 & 3 & 4.3 & 3.2 & 4.1 & 2.9 & 4.1 & 4.3 & 2.1 & 2 & 2 \\
\hline Tater Canyon & NE-HG-C & 4.2 & 2 & 1.4 & 4.6 & 2.2 & 4.4 & 2.6 & 3.6 & 2.6 & 3.7 & 3.9 & 2.6 & 3.3 & 2.4 & 1 & 0 \\
\hline Tater Canyon Upper & NE-HG-C & 4.7 & 1.8 & 2.8 & 4 & 3.6 & 3.8 & 4.8 & 3 & 4 & 3.2 & 5 & 2.1 & 4.7 & 2.3 & 0 & 1 \\
\hline Tilton & NW-H-H & 4.5 & 1 & 2.8 & 2.2 & 4.2 & 2.6 & 4.9 & 1.9 & 4.1 & 1.9 & 3.8 & 2.9 & 3.7 & 1.9 & 0 & 1 \\
\hline Trailview & NNEF-C & 3.7 & 1.2 & 4.6 & 0.6 & 4.4 & 1.2 & 5.5 & 1 & 4.5 & 1 & 4.8 & 0.9 & 2.4 & 0.4 & 0 & 0 \\
\hline Typha & NW-H-H & 4.4 & 1 & 5.4 & 1 & 5.2 & 1.2 & 3.8 & 3.5 & 4.7 & 1.7 & 5.6 & 1.3 & 2.7 & 1.9 & 5 & 6 \\
\hline Unnamed 8 & NW-HG-H & 4.3 & 1.3 & 6 & 1 & 5.2 & 2 & 5 & 2.3 & 5.1 & 1.6 & 5.4 & 2 & 3.6 & 1.6 & 6 & 5 \\
\hline Upper Sowats Seep & NW-HG-T & 4.2 & 1.7 & 6 & 1 & 5.2 & 2 & 6 & 1 & 5.3 & 1.4 & 5.4 & 2 & 3.6 & 1.6 & 6 & 5 \\
\hline Upper Two & NW-R-K & 3.6 & 1.8 & 1.8 & 4 & 2.8 & 3.6 & 3.5 & 2.5 & 2.9 & 3 & 4.4 & 2.3 & - & - & 10 & 9 \\
\hline VT Lake & NC-L-K & 5.6 & 2 & 4 & 2.5 & 4.2 & 3.2 & 4.6 & 3.1 & 4.6 & 2.7 & 2.4 & 2.8 & 3.7 & 2.1 & 2 & 2 \\
\hline Warm & $\mathrm{NW}-\mathrm{Ca}-\mathrm{C}$ & 3.5 & 2.7 & 2.4 & 4.4 & 2 & 4.2 & 2.9 & 4.5 & 2.7 & 3.9 & 2.9 & 3.4 & 4.3 & 1.8 & 9 & 9 \\
\hline Watts & NW-H-K & 3.8 & 2.2 & 2.4 & 3.6 & 2 & 3.6 & 2.5 & 3.6 & 2.7 & 3.2 & 3.9 & 3.1 & 3.7 & 1.9 & 9 & 9 \\
\hline White & NW-H-H & 4.3 & 1.3 & 6 & 1 & 5.2 & 2 & 4.8 & 2.5 & 5.1 & 1.7 & 5.8 & 1.3 & 4.1 & 1.4 & 6 & 5 \\
\hline Wild Horse & S-R-B & 4.2 & 1 & 4.4 & 1.8 & 4 & 1.8 & 4.6 & 1.9 & 4.3 & 1.6 & 5.3 & 1.6 & 3.7 & 2.5 & 0 & 1 \\
\hline Wild Horse Upper & S-R-B & 4.2 & 1 & 4.4 & 1.8 & 4 & 2.3 & 4.8 & 2 & 4.3 & 1.8 & 4.7 & 1.9 & 3.7 & 2.5 & 0 & 3 \\
\hline Wildband & NW-H-T & 4.7 & 0.8 & 4.6 & 1.4 & 4.4 & 2.4 & 4.8 & 2.3 & 4.6 & 1.7 & 4.3 & 1.6 & 3.9 & 2 & 0 & 1 \\
\hline Willow & S-R-B & 4.3 & 3 & 4.8 & 1.4 & 4.2 & 1.6 & 3.4 & 3.8 & 4.2 & 2.4 & 4.6 & 1.6 & 4.1 & 1.6 & 0 & 1 \\
\hline
\end{tabular}


flows varied between 50 and $100 \mathrm{~m}^{3} / \mathrm{s}$ (U.S. Geological Survey, 2016). Post-dam minimum flows are presently kept at or above $141.6 \mathrm{~m}^{3} / \mathrm{s}$ through a political agreement (U.S. Geological Survey, 2016). Thus regional springs contributed 10-20 percent of the pre-dam Colorado River base flow in the Grand Canyon, and presently provide more than 7 percent of the post-dam base flow.

The springs ecosystems in Kaibab National Forest offer a wide array of research and stewardship opportunities. Further inventories of the springs will help refine our understanding of them and of springs-dependent species distribution and status, and monitoring of selected springs may help the FS better understand natural variability and aquifer responses to climate change. Further research on the role of physical variables affecting springs vegetation and invertebrate species presence also may help the FS better understand why and how so many rare species occur at springs. Springs in the southern Colorado Plateau have been recognized as keystone ecosystems, habitats that disproportionally contribute to the physical and biological processes of surrounding landscapes (Perla and Stevens, 2008). Improved understanding of how and how much the springs in Kaibab National Forest influence adjacent lands may help further refine management priorities and actions.

We observed nearly one-third of the flora in Kaibab National Forest on only 6.1 ha of springs habitat. This remarkably tight packing of plant species at springs has also been reported at springs in the Spring Mountains of southern Nevada and in southern Alberta. Springs support not only wetland plant species but also many upland species, and larger springs and some particular springs types (for example, rheocrene, hillslope, and helocrene springs) may passively acquire more plant species because of the relatively strong species-area relation at springs, including anemochores and hydrochores. Greater soil moisture may locally reduce the intensity of wildfires around springs, and thus allow springs to serve as regeneration hotspots after fire or drought, at least for some biota.

The inventory and SEAP data presented here are a first step in determining stewardship options and priorities. Using our data and additional information, Paffett (2014) conducted a refined prioritization assessment of the springs in Kaibab and adjacent Coconino National Forests. He led a discussion with forest staff to rank springs stewardship needs in relation to issues of management urgency, efficiency, and cost. In concert with a revised Forest Plan that identifies springs stewardship and restoration as management priorities, and in collaboration with the Hopi and North Kaibab Paiute Tribes and the primary allotment holder, the FS recently initiated restoration actions on Big and Castle Springs in the North Kaibab Ranger District. Monitoring of those restoration efforts may help the FS better understand the costs and benefits of such collaborative resource management efforts (for example, Stacey and others, 2011). Thus, for many reasons, attention to and sustainable stewardship of springs ecosystems may contribute to FS overall management objectives.

\section{Acknowledgments}

This research was funded by a Kaibab National Forest cost share agreement to the Museum of Northern Arizona under FS Project Agreement 10-CS-11030700-023. We thank the Museum of Northern Arizona for administrative and curatorial support in this project, particularly its president, Robert Breunig. We greatly appreciate the Grand Canyon Wildlands Council, the Grand Canyon Trust, and Stevens Ecological Consulting for contributing data and volunteers in support of our study. We thank Stephen Monroe from the Colorado Plateau Network of the National Park Service in Flagstaff, Ariz., for his contribution of springs inventory data. Boris Kondratieff (Colorado State University) and Richard Durfee assisted in the identification of Coleoptera and Plecoptera, and we thank Richard A. Bailowitz for his assistance in the identification of Odonata and Lepidoptera. Dustin Berger and Kit MacDonald provided insight into the administrative context of springs management in the North Kaibab and Williams Ranger Districts, respectively. We particularly thank Abe Springer and his students for hydrology assistance, and Glenn Rink for his indefatigable logistical assistance and botanical expertise. Additional funding from the Nina Mason Pulliam Charitable Trust through the Grand Canyon Wildlands Council provided transportation, meals, and participation by Beep Jenkins from the Hopi Tribe and Andrea Hazelton, botanist for the Navajo Nation. We warmly thank the many students and volunteers for their field and laboratory assistance, particularly Victoria Hermosillo, Kumi Isobe, Vera Markgraf, Frank Romaglia, Krista Sparks, Phoebe Stevens, and Dan Taylor. Barbara Ralston and anonymous reviewers provided a helpful review of the manuscript. Data from this project are archived at Springs Online (http://springsdata.org).

\section{References Cited}

Arizona State Land Department, 1993, Springs shapefile: Arizona Land Resource Information System.

Arizona State Land Department, 2008, Springs NHD shapefile: Arizona Land Resource Information System: Arizona Geographic Information Council.

Brown, B.T., and Moran, M.S., 1979, An inventory of surface water resources in Grand Canyon National Park, Arizona: National Park Service, Grand Canyon National Park, Division of Resource Management 208 Water Quality Project, pt. 1, 46 p., http://springstewardship.org/PDF/ Brown_Moran_1979.pdf.

Bureau of Land Management, 2011, Northern Arizona proposed withdrawal draft environmental impact statement: St. George, Utah, Bureau of Land Management, http://www. blm.gov/az/st/en/info/nepa/environmental_library/eis/nazdeis.html. 
Ceroici, W.J., and Prasad, B.S., 1977, Hydrogeology of the Canmore Corridor, Alberta: Edmonton, Canada, Alberta Research Council, Groundwater Division, 72 p.

Crossey, L.J., and Karlstrom, K.E., 2012, Travertines and travertine springs in eastern Grand Canyon-What they tell us about groundwater, paleoclimate, and incision of Grand Canyon, in Timmons, J.M., and Karlstrom, K.E., eds., Grand Canyon geology_-Two billion years of Earth's history: Geological Society of America Special Paper 489, p. 131-143, http://specialpapers.gsapubs.org/ content/489/131.

Flora, S.P., 2004, Hydrogeological characterization and discharge variability of springs in the Middle Verde River watershed, central Arizona: Flagstaff, Northern Arizona University, M.S. thesis, 237 p., http://springstewardship.org/ PDF/flora04.pdf.

Grand Canyon Wildlands Council, 2002, An inventory, assessment, and development of recovery priorities for Arizona strip springs, seeps and natural ponds - A synthesis of information: Flagstaff, Ariz., Grand Canyon Wildlands Council report submitted to Arizona Water Protection Fund, 49 p.

Grand Canyon Wildlands Council, 2005, An ecological assessment of water resources, Kane and Two Mile Ranches, eastern Arizona strip: Flagstaff, Ariz., Stevens Ecological Consulting report submitted to Grand Canyon Trust, 68 p., http://www.grandcanyontrust.org/sites/default/ files/NRR_Water_Resources_Report2005.pdf.

Hallam, V.G., 2010, Detailed statistical analyses of fundamental properties of springs ecosystems in relation to their geomorphological and ecological diversity: Flagstaff, Northern Arizona University, M.S. thesis, 117 p.

Howard, J., and Merrifield, M., 2010, Mapping groundwater dependent ecosystems in California: PlosOne, v. 5, no. 6, doi:10.1371/journal.pone.0011249.

Kreamer, D.K., and Springer, A.E., 2008, The hydrology of desert springs in North America, in Stevens, L.E., and Meretsky, V.J., eds., Aridland springs in North AmericaEcology and conservation: Tucson, University of Arizona Press, p. 35-48.

Ledbetter, J.L., Stevens, L.E., and Springer, A.E., 2012, Springs inventory database: Flagstaff, Ariz., Springs Stewardship Institute, available at http://springsdata.org/.

Lenat, D.R., 1988, Water quality assessment of streams using a qualitative collection method for benthic macroinvertebrates: Society for Freshwater Science, v. 7, no. 3, p. 222-233, http://www.jstor.org/stable/1467422.

Merritt, R.W., Cummins, K.W., and Berg, M.B., eds., 2008, An introduction to the aquatic insects of North America (4th ed.): Dubuque, Iowa, Kendall Hunt, 1158 p.
Paffett, K.P., 2014, Analysis of springs assessment data for stewardship in the Coconino and Kaibab National Forests, Northern Arizona: Flagstaff, Northern Arizona University, M.S. thesis, 94 p., http://search.proquest.com/ docview/1545690952.

Perla, B.S., and Stevens, L.E., 2008, Biodiversity and productivity at an undisturbed spring, in comparison with adjacent grazed riparian and upland habitats, in Stevens, L.E., and Meretsky, V.J., eds., Aridland springs in North America-Ecology and conservation: Tucson, University of Arizona Press, p. 230-243.

Samuelson, G.M., and Rood, S.B., 2011, Elevated sensitivity-Riparian vegetation in upper mountain zones is especially vulnerable to livestock grazing: Applied Vegetation Science, v. 14, no. 4, p. 596-606, http://dx.doi. org/10.1111/j.1654-109X.2011.01137.x.

Sellers, W.D., Hill, R.H., and Sanderson-Rae, M., eds., 1985, Arizona climate-The first hundred years, 1885-1985: Tucson, University of Arizona Press, 143 p.

Spellerberg, I.F., and Fedor, P.J., 2003, A tribute to Claude Shannon (1916-2001) and a pleas for more rigorous use of species richness, species diversity and the 'ShannonWiener' index: Global Ecology and Biogeography, v. 12, no. 3, p. 177-179, http://www.jstor.org/stable/3697500.

Springer, A.E., and Stevens, L.E., 2008, Spheres of discharge of springs: Hydrogeology, v. 17, no. 1, p. 83-93, http:// dx.doi.org/10.1007/s10040-008-0341-y.

Springer, A.E., Stevens, L.E., Ledbetter, J.D., Schaller, E.M., Gill, K.M., and Rood, S.B., 2014, Ecohydrology and stewardship of Alberta springs ecosystems: Ecohydrology, v. 8, no. 9, doi:10.1002/eco.1596.

Stacey, C.J., Springer, A.E., and Stevens, L.E., 2011, Have arid land springs restoration projects been effective in restoring hydrology, geomorphology, and invertebrate and plant species composition comparable to natural springs with minimal anthropogenic disturbance?: Flagstaff, Ariz., Collaboration for Environmental Evidence Review 10-002 (SR87), 74 p., http://www.environmentalevidence.org/ wp-content/uploads/2014/07/SR87.pdf.

Stevens, L.E., 2012, The biogeographic significance of a large, deep canyon - Grand Canyon of the Colorado River, southwestern USA, in Stevens, L.E., ed., Global advances in biogeography: Rijecka, Croatia, InTech, p. 169-208, http://www.intechopen.com/books/global-advancesinbiogeography/the-biogeographic-significance-of-a-largedeep-canyon-grand-canyon-of-the-colorado-river-usa.

Stevens, L.E., and Meretsky, V.J., 2008, Aridland springs in North America-Ecology and conservation: Tucson, University of Arizona Press, 406 p. 
Stevens, L.E., Springer, A.E., and Ledbetter, J.L., 2011, Inventory and monitoring protocols for springs ecosystems: Flagstaff, Ariz., Springs Stewardship Institute, http://docs.springstewardship.org/PDF/Springs_Inventory_Protocols_110602.pdf.

U.S. Forest Service, 1986, Final Environmental Impact Statement canyon uranium mine: Williams, Ariz., Southwestern Region, Kaibab National Forest, 232 p., http://www.fs.usda.gov/Internet/ FSE_DOCUMENTS/stelprdb5346657.pdf.
U.S. Geological Survey, 2016, USGS 09380000 Colorado River at Lees Ferry, AZ: U.S. Geological Survey Daily Statistics for the Nation, available at http://waterdata. usgs.gov/usa/nwis/dvstat/?site_no $=09380000 \&$ por_09380000_1=19133,00060,1.

Williams, D.D., and Danks, H.V., 1991, Arthropods of springs (Introduction): Memoirs of the Entomological Society of Canada, v. 123 , no. 155 , p. 3-5. 


\title{
Chapter E
}

\section{Fungal Diversity in Biological Soil Crusts of the Colorado Plateau}

\author{
By Blaire Steven, ${ }^{*}$ Cedar Hesse, ${ }^{1}$ La Verne Gallegos-Graves, ${ }^{1}$ Jayne Belnap, ${ }^{2}$ and Cheryl R. Kuske ${ }^{1}$
}

\section{Abstract}

We report the results of a replicated fungal large-subunit ribosomal RNA gene sequencing survey, conducted on biological soil crusts (biocrusts) of the Colorado Plateau. Fungal communities were characterized from two sites approximately 15 kilometers apart; the soil at each of the sites was derived from sandstone and shale material, respectively. Fungal large-subunit ribosomal RNA gene sequences recovered from the biocrusts on soil derived from sand were consistently more diverse than those from shale. Sample to sample heterogeneity was high, and the majority of fungal sequence types were unique to a single sample. This suggests a high level of spatial variability in the biocrust fungal community. A small number of fungal lineages were found that were shared between the two soil types. The conserved fungal taxa were predominantly within the class Dothideomycetes, order Pleosporales or were not reliably classified. This replicate sequencing strategy has shed light on the heterogeneity of biocrust fungal communities at different spatial scales, and has identified conserved fungal lineages that may play essential roles in biocrust functioning. These results suggest that fungi, particularly certain lineages of Pleosporales, should be considered as common and potentially important biocrust members.

\section{Introduction}

Biological soil crusts (hereafter referred to as biocrusts) are an important ecosystem component of the Colorado Plateau. Biocrusts are biological communities, consisting of bacteria, algae, archaea, fungi, lichens, and mosses that colonize the topsoils in drylands and are a conspicuous aspect of the Colorado Plateau landscape (fig. 1; Belnap, 2003; Pointing and Belnap, 2012). Biocrusts play many functional roles in the environment including soil stabilization, reduction

\footnotetext{
${ }^{1}$ Biological Science Division, Los Alamos National Laboratory

${ }^{2}$ U.S. Geological Survey

"Now at Department of Environmental Sciences, Connecticut Agricultural Experiment Station
}

of erosion, moisture retention, and carbon and nitrogen fixation (Belnap, 2002, 2003; Housman and others, 2006).

In this study we focus on the fungal diversity of biocrusts. In soil environments fungi perform multiple and diverse roles. They are important in the decomposition and recycling of carbon, in modification of the soil environment, as partners in mutualistic symbioses, and as potential pathogens of plants (Christensen, 1989). In biocrusts, fungi are algal symbionts in lichenized biocrusts (Bates and others, 2010a). Nitrogen transformations, particularly the production of $\mathrm{N}_{2} \mathrm{O}$, are likely driven by biocrust fungi (Crenshaw and others, 2008; Marusenko and others, 2013). The fungal populations in dryland soils have also been implicated in forming nutrient bridges between local plants and the biocrusts that may translocate carbon and nitrogen (Green and others, 2008; Porras-Alfaro and others, 2010).

Although the bacterial community structure in the biocrusts of the Colorado Plateau has been described in detail (for example, Yeager and others, 2004; Steven and others, 2013), few studies document the diversity and structure of the fungal populations. Two previous studies employing the DNA

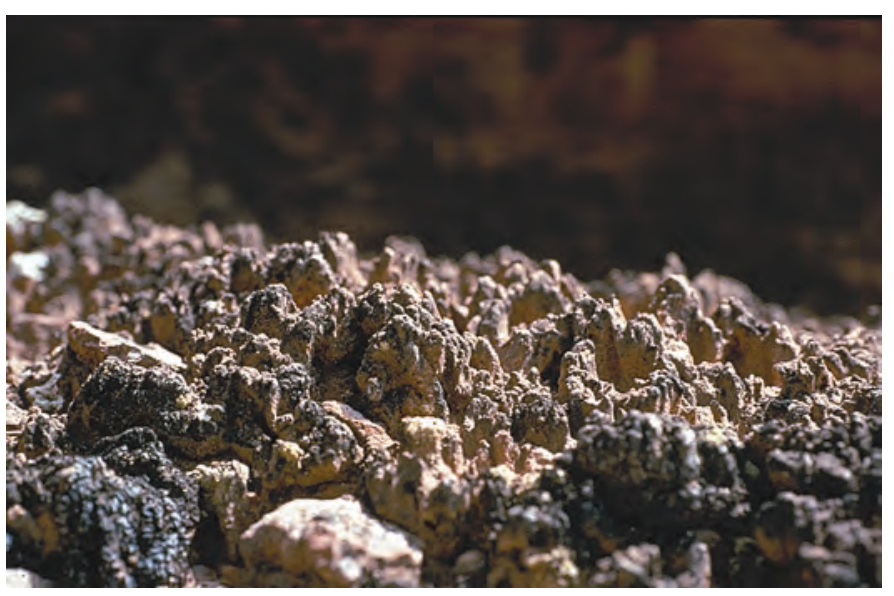

Figure 1. Photograph of a Colorado Plateau biocrust. Biocrusts appear as the dark pigmented surface layers. The dark coloration is due to the biological pigment, scytonemin, produced by cyanobacteria. 
fingerprinting technique denaturing gradient gel electrophoresis (DGGE) and quantitative polymerase chain reactions (qPCR) found that Colorado Plateau biocrust fungi were generally less abundant and diverse than the biocrust bacteria. The dominant fungal lineages recovered in these studies were within the phylum Ascomycota, predominantly related to fungi within the order Pleosporales (Bates and Garcia-Pichel, 2009; Bates and others, 2010b). Similarly, abundant fungal populations recovered in culture-based studies of New Mexico grassland biocrusts and Mojave Desert biocrusts were related to the Pleosporales (Porras-Alfaro and others, 2010; Steven and others, 2014). In these diverse studies the identified fungi were predominantly microcolonial lineages. The microcolonial fungi have been identified in desert soils worldwide and form darkly pigmented, melanized hyphae and spores that allow them to survive the desiccating conditions of dryland soils (Sterflinger and others, 2012). However, because of the limited resolution and replication applied in previous studies there is still a knowledge gap concerning the spatial patterning, patchiness, diversity, and composition of fungal populations in Colorado Plateau biocrusts.

The goal of this study was to document patterns of fungal taxonomy and distribution in biocrusts of the Colorado Plateau employing a replicated, high-resolution sequencing study. Fungal communities were characterized from two soil types using sequencing of the large subunit (LSU) ribosomal RNA (rRNA) gene to generate an inventory of fungal populations in the biocrusts, and to characterize how these populations varied between biocrusts collected at two sites that differed in soil parent material.

\section{Site Description and Methods}

Biocrust samples were collected from two distinct soil types in the vicinity of Moab, Utah on October 14, 2011. The sand soil samples (Arches Series) were collected from within the Island of the Sky district of Canyonlands National Park (38'27'27.21'”N, 109³2'27.93'’W, 550 meters [m] elevation). The soil was a sandy loam consisting of eolian and residuum deposits derived from the local sandstone (Navajo Sandstone). The shale soil (Rizzo Series, Moenkopi Formation) was located near Castle Valley, Utah (3840'29.5'N, 10949'58.7'W, 399 m elevation). The soil characteristics and bacterial communities of these soil types have been documented previously (Steven and others, 2013). Three replicate surface biocrust samples were collected at each location. Biocrust samples were defined as the soil bound together by the cyanobacterial mats at a depth of $<1$ centimeter. Samples were specifically collected from areas not showing visible lichen patches to focus on cyanobacterially dominated biocrusts. Each sample, approximately 5 grams, was immediately placed on dry ice for transportation to Los Alamos National Laboratory. Samples were stored at $-70{ }^{\circ} \mathrm{C}$ until processing.

Total community DNA was extracted from the biocrust samples using the FastDNA prep kit (MP Biomedicals) using the included protocols. Successful DNA extractions were verified by gel electrophoresis and were quantified using the Quant-iT PicoGreen dsDNA kit (Invitrogen). Polymerase chain reaction amplification for 454 Titanium sequencing (Los Alamos National Laboratory Sequencing Center, standard protocols) was performed using 0.5 nanograms of each template DNA. Fungal LSU rRNA genes were amplified with the primers LROR and LR3 using amplification protocols described previously (Steven and others, 2014). The recovered sequences were processed and analyzed in the mothur software package (v.1.25.1; Schloss and others, 2009). Sequences were quality checked and processed as described previously (Steven and others, 2013). Sequences were screened for nonfungal eukaryotes using BLAST and MEGAN5 software (Altschul and others, 1990; Huson and others, 2007). Fungal sequences were aligned using the fungal $28 \mathrm{~S}$ rRNA alignment tool from the Ribosomal Database Project (RDP; Cole and others, 2014) and classification of sequences was performed using the naïve Bayesian classifier with the January 2014 version of the fungal LSU database, available through the RDP website (Liu and others, 2012; Porras-Alfaro and others, 2014). Operational taxonomic units (OTUs) were determined as sequences sharing $\geq 97$ percent sequence identity in the mothur software package. For calculations of diversity statistics and proportion of shared OTUs the datasets were randomly subsampled to the size of the smallest dataset to maintain equal sampling effort. For analysis of molecular variance (AMOVA), sample similarities were calculated employing the Bray-Curtis similarity metric. AMOVA statistics, testing whether the genetic diversity of two samples differs significantly, were calculated in the mothur software package. The fungal LSU sequences are publicly available on the MG-RAST website (Meyer and others, 2008) under the ID number 4550096.3 (http://metagenomics.anl.gov).

\section{Results}

\section{Sequencing and Diversity Statistics}

A total of 7,563 high quality fungal LSU sequences with an average length of 275 base pairs were analyzed in this study. The number of sequences recovered from each sample, the estimated coverage, and the diversity statistics for each sample are shown in table 1.

The number of OTUs from sand soils was consistently and significantly higher than in the shale soil (paired t-test; $\mathrm{p}=0.02$ ). Fungi were also more diverse ( $\left.H^{\prime}\right)$ in the sand soils than the shale soils (table 1). Across the datasets the estimated coverage of fungal diversity ranged from 80 to 89 percent, suggesting that the majority of the fungal OTU diversity expected to occur in these samples was recovered with this sampling effort. Finally, the ChaoI diversity estimate, a nonparametric species estimator, suggests approximately 580 OTUs would be recovered from sand soils compared to 346 from shale when completely sampled (table 1). AMOVA 
statistics were determined to test if the sand and shale soils harbored significantly different fungal communities. The difference in community structure between the two soil types was highly significant $(\mathrm{p}<0.001)$.

\section{Taxonomic Composition of Fungal Communities}

The LSU sequences were classified to the class-level to compare the taxonomic composition of the fungal communities (fig. 2). The majority of the LSU sequences belonged to two fungal phyla, the Ascomycota and the Chytridiomycota. Additionally, a small number of sequences were also identified within the phylum Basidiomycota, but do not appear in figure 2 as they generally accounted for $<1$ percent of the sequence

Table 1. Sample size, coverage and diversity statistics for the large subunit (LSU) datasets.

[OTU, operational taxanomic unit, \%, percent]

\begin{tabular}{|c|c|c|c|c|c|}
\hline \multirow{2}{*}{ Sample } & \multicolumn{2}{|c|}{ Number } & \multirow{2}{*}{$\mathrm{H}^{\prime 2}$} & \multirow{2}{*}{$\begin{array}{c}\text { Coverage } \\
(\%)^{2}\end{array}$} & \multirow{2}{*}{ Chaol $^{2}$} \\
\hline & Sequences & OTUs ${ }^{2}$ & & & \\
\hline Sand_crust_1 & 1,355 & 228 & 4.7 & 80.3 & 582 \\
\hline Sand_crust_2 & 1,129 & 240 & 4.8 & 79.7 & 558 \\
\hline Sand_crust_3 & 1,087 & 217 & 4.4 & 81.5 & 602 \\
\hline Average & $1,190.3$ & 228.3 & 4.6 & 80.5 & 580.7 \\
\hline Shale_crust_1 & $768^{1}$ & 150 & 4.1 & 88.5 & 351 \\
\hline Shale_crust_2 & 1,009 & 129 & 3.0 & 88.5 & 354 \\
\hline Shale_crust_3 & 2,215 & 148 & 3.9 & 88.4 & 334 \\
\hline Average & $1,330.7$ & 142.3 & 3.7 & 88.5 & 346.3 \\
\hline
\end{tabular}

1Smallest dataset to which the other datasets were randomly subsampled.

${ }^{2}$ Calculated with an operational taxonomic unit (OTU) definition of 97 percent sequence identity. datasets. The majority of sequences within the Ascomycota belonged to six classes that varied widely in relative abundance between the replicates (fig. 2). Finally, a relatively large proportion of the sequences could not be assigned to known fungal taxa using the naïve Bayesian classifier. Putative taxonomic identities based on the best BLAST match reveal that many unclassified Ascomycota-related OTUs likely belong to lichenized lineages, including Heppia (89 percent sequence similarity, class Lichinomycetes) and Parmeliella (90 percent sequence similarity; class Lecanoromycetes). It is important to note that these classifications are based on best BLAST matches and may not represent the true taxonomic affiliation of the recovered sequences. However, these sequences were $>90$ percent similar to fungal sequences recovered from Mojave Desert biocrusts (Steven and others, 2014), suggesting these fungal lineages are consistently recovered in biocrusts of the Southwest U.S. These data indicate that biocrusts contain significant populations of previously undescribed fungal and lichen diversity.

The only fungal class that was present in both soil types was the Dothideomycetes, which accounted for $\sim 3$ to 40 percent of the sequences (fig. 2). Within this class, the order Pleosporales accounted for 81 to 92 percent of the sequences, making them the most numerically abundant order recovered (data not shown). Within the order Pleosporales, sequences could be classified into 17 distinct genera, of which only two, Alternaria and Preussia, were present across all of the samples. Many plant-associated dark-septate fungi have been identified within the Pleosporales from similar arid environments; therefore it is likely that the prevalence of Pleosporales in these samples reflects an abundance of dark-septate fungi. Taken together our compositional data show high heterogeneity among biocrust fungal communities both locally (between soil type replicates) and between soil types. Members of the Eurotiomycetes were encountered in two of the shale soil samples and one of the sand soil samples. These

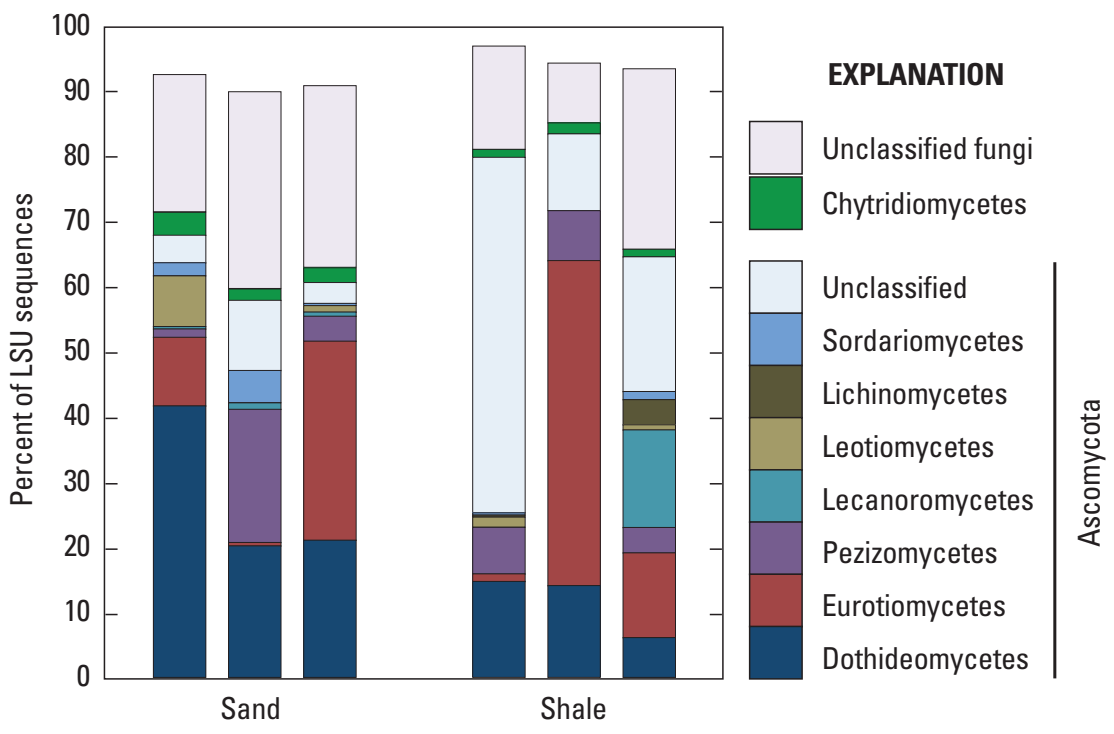

Figure 2. Plot of class-level taxonomic bins in the large subunit (LSU) datasets. Only those classes that accounted for $>1$ percent of sequences in at least one dataset are displayed, so the bars do not sum to 100 percent. 
sequences were primarily in the order Verrucariales, which contains lichenized fungi that likely evolved independently from the other two major lichenized classes (Lichinomycetes and Lecanoromycetes). The largest group of "rare" Ascomycota was found in a single shale soil sample and represents a single OTU closely related to the lichenized genus Psora (Lecanoromycetes).

\section{Defining a Core Biocrust Fungal Community}

The datasets were investigated for shared OTUs in order to define a core fungal community. In each comparison, OTUs composed of a single sequence (singletons) were removed. OTUs were identified that were common between replicate samples for each soil type and between the two soil types (fig. 3). Many OTUs were unique to the individual datasets, ranging from 36 to 54 percent of the identified nonsingleton OTUs (fig. $3 A, B$ ). The proportion of OTUs unique to each dataset was higher in the sand soil biocrusts. However, given the higher diversity of fungi in the sand soil biocrusts (table 1), this may be due to under-sampling of the sand communities when the datasets were normalized to the same size. A small number of OTUs were also common between the sand and shale soils (fig. 3C).

Shared OTUs (those in common between the two soils) were primarily in the Dothideomycetes (fig. 3D) and unclassified Ascomycota, which were often most closely related to Dothideomycete fungi (data not shown). Many of the conserved OTUs were unclassified fungi, suggesting that even fungi that are common in biocrusts may be poorly represented in current taxonomic databases. Only five OTUs were conserved among all replicates of the two soil types (table 2). These OTUs likely represent fungi that have been strongly selected for their presence in the biocrusts.

With the exception of a single OTU (OTU-5) all of the OTUs belonged to the class Dothideomycetes. Two of the OTUs were further classified to the order Pleosporales and the final two OTUs were classified to the genera Alternaria and Preussia within the order Pleosporales (table 2). The one OTU that could not be assigned to a class was only 79 percent similar to its nearest neighbor in GenBank, suggesting that this is either an example of a novel fungal lineage in the biocrusts or potentially a nonfungal eukaryote. Interestingly, two of the OTUs (OTUs 1 and 3 ) were most closely related to LSU sequences recovered in a previous study of fungal diversity in Mojave Desert biocrusts (Porras-Alfaro and others, 2014) and another (OTU-5) was related to an LSU sequence recovered from a sandy soil sample collected under a piñon pine in $\mathrm{New}$ Mexico (Eichorst and Kuske, 2012). In this respect, these OTUs may not only be conserved between biocrusts of the Colorado Plateau but may be distributed among drylands at a much larger scale.

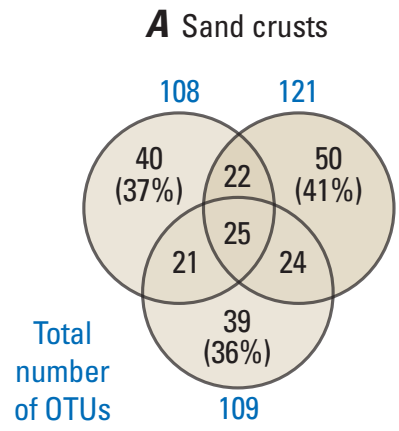

$\boldsymbol{B}$ Shale crusts

$\boldsymbol{C}$ Between sand and shale
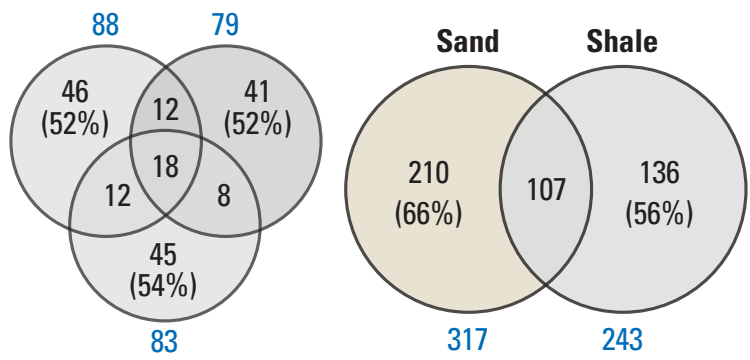

D Taxonomic composition of conserved OTUs

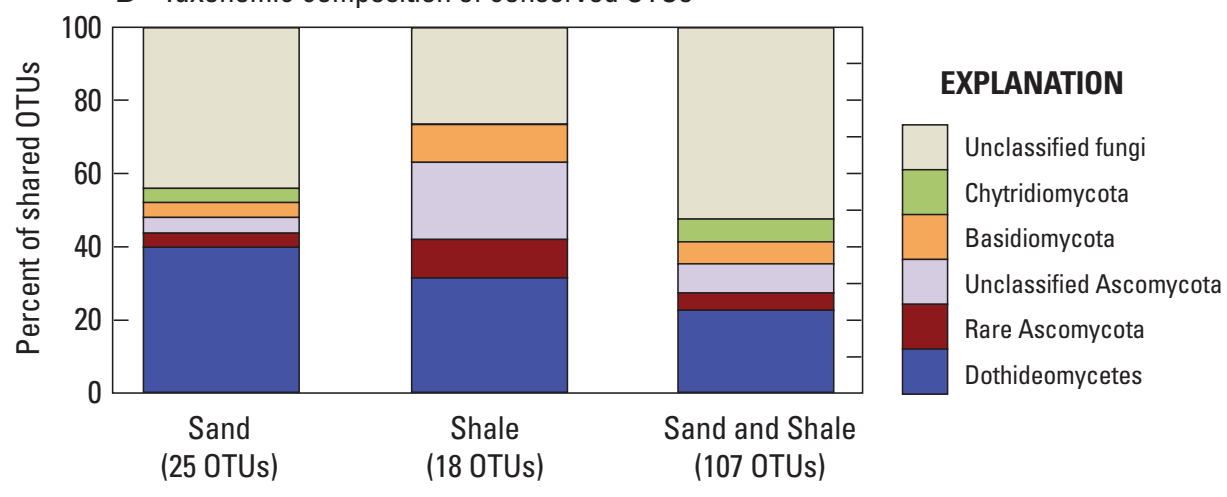

Figure 3. Plots of shared operational taxonomic units (OTUs) between datasets. The number of shared OTUs was determined between replicate samples ( $A$, $B$ ) and between the sand and shale soils $(C)$. The total number of OTUs in each dataset (after removal of singletons) is indicated outside of the circles. OTUs shared between datasets are indicated in the overlapping portions of the diagrams. Inset percentages indicate the proportion of OTUs unique to each dataset. $D$, displays the taxonomic composition of the shared OTUs. Note that they are the OTUs shared between all three replicates or in the compiled sand and shale soil datasets, so each bar represents a different number of OTUs (indicated by the number below the bars). 
Table 2. Classification of conserved operational taxonomic units (OTUs) between all sequence datasets.

\begin{tabular}{llcllll}
\hline OTU & \multicolumn{1}{c}{ Closest BLAST match } & $\begin{array}{c}\% \\
\text { Sequence } \\
\text { ID }^{1}\end{array}$ & $\begin{array}{c}\text { Isolation } \\
\text { source }\end{array}$ & Accession & Taxonomy ${ }^{2}$ \\
\hline 1 & Uncultured clone NTS_064A_3 & 97 & Moab biocrust & KC558465.1 & Pleosporales (83) \\
2 & Fungal sp. BG29 & 94 & Endophyte & JQ249257.1 & Alternaria (85) \\
3 & Uncultured clone NTS_054A & 95 & Moab biocrust & KC558210.1 & Pleosporales (83) \\
4 & Fungal sp. BG80 & 95 & Endophyte & JQ249246.1 & Preussia (85) \\
5 & Uncultured clone OTU91-167 & 79 & Piñon soil & JQ310904.1 & Fungi (86) \\
\hline
\end{tabular}

${ }^{1}$ Percent sequence identity to nearest neighbor in GenBank.

${ }^{2}$ Represents the finest scale taxonomy to which the representative sequence could be classified reliably $(>60$ percent confidence score). The confidence score of the classification is indicated in parentheses.

\section{Discussion}

This sequence-based study documented the composition and biogeography of fungal communities in biocrusts of the Colorado Plateau. Our results show that edaphic factors related to soil parent material may influence the structure of the fungal communities. The structure of the fungal communities was found to differ significantly between the two soils sampled in this study (AMOVA analysis, $\mathrm{p}<0.001$ ). More specifically, the sand soils supported a more rich and diverse fungal community than the shale soils (table 1). Furthermore, the shale soils contained lower relative abundances of Dothideomycetes compared to sand biocrusts (fig. 2). The decrease in Dothideomycetes in the shale soil was accompanied by an increase in the proportion of unclassified Ascomycota-related fungi (fig. 2). Our preliminary examination of the unclassified sequences suggests a large part of these sequences likely represent Dothideomyceterelated fungi that are poorly represented in current databases. Patterns in fungal diversity related to soil type differed from observations of bacterial communities from the same biocrusts, which were generally more similar in their diversity and composition across large spatial scales and different soil types (Steven and others, 2013). In this regard, biocrust fungal populations appear to be affected differently than bacteria by local edaphic factors. We suggest defining the specific soil characteristics that control the composition of fungal communities be pursued to determine the environmental drivers of biocrust fungal community structure.

Variability was high among the replicate field samples (fig. 2). These patterns suggest that fungal community composition varied substantially between samples separated at relatively small spatial scales. For example, 36 to 41 percent of the fungal OTUs in the sand biocrusts were unique to each dataset compared to 52-54 percent in the shale biocrust datasets (fig. 3B). Prior measures of fungal biomass, culturable fungal counts, DGGE fingerprints, qPCR, and Sanger sequencing were variable among replicate soil samples
(Bates and Garcia-Pichel, 2009; Steven and others, 2014). Our replicated sequencing survey provided higher community sampling coverage than the previous DGGE fingerprinting or Sanger sequencing studies, and provide a more robust and quantitative measure of fungal community composition and the spatial heterogeneity of biocrust fungi.

Most of the fungal OTUs that were shared between the two soil types were members of the class Dothideomycetes (fig. 3D). A recent meta-analysis of fungal diversity across different drylands found that the most common lineages of fungi encountered through both culture-dependent and cultureindependent studies of biocrusts were Dothideomycetes, primarily of the order Pleosporales (Bates and others, 2010b). The only genus that was consistently found across the different studies was Alternaria. Similarly, our analyses identified conserved OTUs predominantly related to the Pleosporales including an OTU belonging to Alternaria (table 2). The data presented here adds to a growing body of literature that suggests Pleosporales-related fungi are important biocrust constituents that are present in biocrusts from many types of drylands. This conservation of specific fungal lineages between biocrusts suggests these fungi are providing important ecosystem services to the biocrusts, which are yet to be determined. While dark-septate fungi within the Pleosporales have been hypothesized to form nutrient bridges between biocrusts and nearby grasses (Green and others, 2008), strong evidence for this interaction is still needed.

Although we attempted to avoid visible lichens in our sampling strategy, we detected numerous lichenized fungal taxa in our sequence survey. The morphology and pigmentation of these lichens may make them difficult to discern on filamentous cyanobacterial biocrusts. For example, the black pigments of species within the Verrucariales may resemble scytonemicpigmented cyanobacterial mats. These results suggest that cyanobacteria-dominated biocrusts are a mixed community of both Cyanobacteria and lichen. Finally, a large proportion of sequences in our survey were not classifiable with the most current LSU databases. This suggests there is still insufficient 
representation of fungal taxa in current reference databases. However, based on the low identity of many sequences to named taxa in the National Center for Biotechnology Information nonredundant nucleotide database, it is likely that arid land biocrusts represent a reservoir of fungal diversity that has not been previously described.

\section{Acknowledgments}

This study was supported by the Laboratory Directed Research and Development program of the Los Alamos National Laboratory, and a Science Focus Area grant (2009LANLF260) from the U.S. Department of Energy, Biological and Environmental Research Division. This is LANL unclassified report LA-UR-14-20460.

\section{References Cited}

Altschul, S.F., Gish, W., Miller, W., Myers, E.W., and Lipman, D.J., 1990, Basic local alignment search tool: Journal of Molecular Biology, v. 215, no. 3, p. 403-410, http://dx.doi. org/10.1016/S0022-2836(05)80360-2.

Bates, S.T., and Garcia-Pichel, F., 2009, A culture-independent study of free-living fungi in biological soil crusts of the Colorado Plateau - Their diversity and relative contribution to microbial biomass: Environmental Microbiology, v. 11, no. 1, p. 56-67, http://dx.doi.org/10.1111/j.14622920.2008.01738.x.

Bates, S.T., Garcia-Pichel, F., and Nash, T.H., III, 2010b, Fungal components of biological soil crusts - Insights from culture-dependent and culture-independent studies, in Nash, T.H., III, Geiser, L., McCune, B., Triebel, D., Tomescu, A.M., and Sanders, W., eds., Biology of Lichens-Symbiosis, Ecology, Environmental Monitoring, Systematics, Cyber Applications: Bibliotheca Lichenologica, v. 105, p. 197-210, http:/www.azfungi.org/ stbates/Bates_et_al_2010Fungal_components_BSCs.pdf.

Bates, S.T., Nash, T.H., III, Sweat, K.G., and Garcia-Pichel, F., 2010a, Fungal communities of lichen-dominated biological soil crusts - Diversity, relative microbial biomass, and their relationship to disturbance and crust cover: Journal of Arid Environments, v. 74, no. 10, p. 1192-1199, http://dx.doi. org/10.1016/j.jaridenv.2010.05.033.

Belnap, J., 2002, Nitrogen fixation in biological soil crusts from southeast Utah, USA: Biology and Fertility of Soils, v. 35, no. 2, p. 128-135, http://dx.doi.org/10.1007/s00374002-0452-x.

Belnap, J., 2003, The world at your feet-Desert biological soil crusts: Frontiers in Ecology and the Environment, v. 1, no. 4, p. 181-189, http://dx.doi.org/10.2307/3868062.
Christensen, M., 1989, A view of fungal ecology: Mycologia, v. 81 , no. 1, p. 1-19, http://dx.doi.org/10.2307/3759446.

Cole, J.R., Wang, Q., Fish, J.A., Chai, B., McGarrell, D.M., Sun, Y., Brown, C.T., Porras-Alfaro, A., Kuske, C.R., and Tiedje, J.M., 2014, Ribosomal database project-Data and tools for high throughput rRNA analysis: Nucleic Acids Research, v. 42, no. D1, p. D633-D642, http://dx.doi. org/10.1093/nar/gkt1244.

Crenshaw, C.L., Lauber, C., Sinsabaugh, R.L., and Stavely, L.K., 2008, Fungal control of nitrous oxide production in semiarid grassland: Biogeochemistry, v. 87, no. 1, p. 17-27, http://dx.doi.org/10.1007/s10533-007-9165-4.

Eichorst, S.A., and Kuske, C.R., 2012, Identification of cellulose-responsive bacterial and fungal communities in geographically and edaphically different soils by using stable isotope probing: Applied and Environmental Microbiology, v. 78, no. 7, p. 2316-2327, http://dx.doi. org/10.1128/AEM.07313-11.

Green, L.E., Porras-Alfaro, A., and Sinsabaugh, R.L., 2008, Translocation of nitrogen and carbon integrates biotic crust and grass production in desert grassland: Journal of Ecology, v. 96, no. 5, p. 1076-1085, http://dx.doi. org/10.1111/j.1365-2745.2008.01388.x.

Housman, D.C., Powers, H.H., Collins, A.D., and Belnap, J., 2006, Carbon and nitrogen fixation differ between successional stages of biological soil crusts in the Colorado Plateau and Chihuahuan Desert: Journal of Arid Environments, v. 66, no. 4, p. 620-634, http://dx.doi. org/10.1016/j.jaridenv.2005.11.014.

Huson, D.H., Auch, A.F., Qi, J., and Schuster, S.C., 2007, MEGAN analysis of metagenomic data: Genome Research, v. 17, p. 377-386, http://dx.doi.org/10.1101/ gr.5969107.

Liu, K.-L., Porras-Alfaro, A., Kuske, C.R., Eichorst, S.A., and Xie, G., 2012, Accurate, rapid taxonomic classification of fungal large-subunit rRNA genes: Applied and Environmental Microbiology, v. 78, no. 5, p. 1523-1533, http://dx.doi.org/10.1128/AEM.06826-11.

Marusenko, Y., Huber, D.P., and Hall, S.J., 2013, Fungi mediate nitrous oxide production but not ammonia oxidation in aridland soils of the southwestern US: Soil Biology and Biochemistry, v. 63, p. 24-36, http://dx.doi. org/10.1016/j.soilbio.2013.03.018.

Meyer, F., Paarman, D., D’Souza, M., Olson, R., Glass, E.M., Kubal, M., Paczian, T., Rodriguez, A., Stevens, R., Wilke, A., Wilkening, J., and Edwards, R.A., 2008, The metagenomics RAST server-A public resource for the automatic phylogenetic and functional analysis of metagenomes: BMC Bioinformatics, v. 9, no. 386, http:// dx.doi.org/10.1186/1471-2105-9-386. 
Pointing, S.B., and Belnap, J., 2012, Microbial colonization and controls in dryland systems: Nature Reviews

Microbiology, v. 10, p. 551-562, http://dx.doi.org/10.1038/ nrmicro2831.

Porras-Alfaro, A., Herrera, J., Natvig, D.O., Lipinski, K., and Sinsabaugh, R.L., 2010, Diversity and distribution of soil fungal communities in a semiarid grassland: Mycologia, v. 103, no. 1, p. 10-21, http://dx.doi.org/10.3852/09-297.

Porras-Alfaro, A., Liu, K.-L., Kuske, C.R., and Xie, G., 2014, From genus to phylum-LSU and ITS rRNA operon regions showed similar classification accuracy influenced by database composition: Applied and Environmental Microbiology, v. 80, no. 3, p. 829-840, http://dx.doi. org/10.1128/AEM.02894-13.

Schloss, P.D., Westcott, S.L., Ryabin, T., Hall, J.R., Hartmann, M., Hollister, E.B., Lesniewski, R.A., Oakley, B.B., Parks, D.H., Robinson, C.J., Sahl, J.W., Stres, B., Thallinger, G.G., Van Horn, D.J., and Weber, C.F., 2009, Introducing mothur-Open-source, platform-independent, communitysupported software for describing and comparing microbial communities: Applied and Environmental Microbiology, v. 75, no. 23, p. 7537-7541, http://dx.doi.org/10.1128/ AEM.01541-09.
Sterflinger, K., Tesei, D., and Zakharova, K., 2012, Fungi in hot and cold deserts with particular reference to microcolonial fungi: Fungal Ecology, v. 5, no. 4, p. 453462, http://dx.doi.org/10.1016/j.funeco.2011.12.007.

Steven, B., Gallegos-Graves, L.V., Belnap, J., and Kuske, C.R., 2013, Dryland soil microbial communities display spatial biogeographic patterns associated with soil depth and soil parent material: FEMS Microbiology Ecology, v. 86, no. 1, p. 101-113, http://dx.doi.org/10.1111/15746941.12143.

Steven, B., Gallegos-Graves, L.V., Yeager, C., Belnap, J., and Kuske, C.R., 2014, Common and distinguishing features of the bacterial and fungal communities in biological soil crusts and shrub root zone soils: Soil Biology and Biochemistry, v. 69, p. 302-312, http://dx.doi.org/10.1016/j. soilbio.2013.11.008.

Yeager, C.M., Kornosky, J.L., Housman, D.C., Grote, E.E., Belnap, J., and Kuske, C.R., 2004, Diazotrophic community structure and function in tow successional stages of biological soil crusts from the Colorado Plateau and Chihuahuan Desert: Applied and Environmental Microbiology, v. 70, no. 2, p. 973-983, http://dx.doi. org/10.1128/AEM.70.2.973-983.2004. 


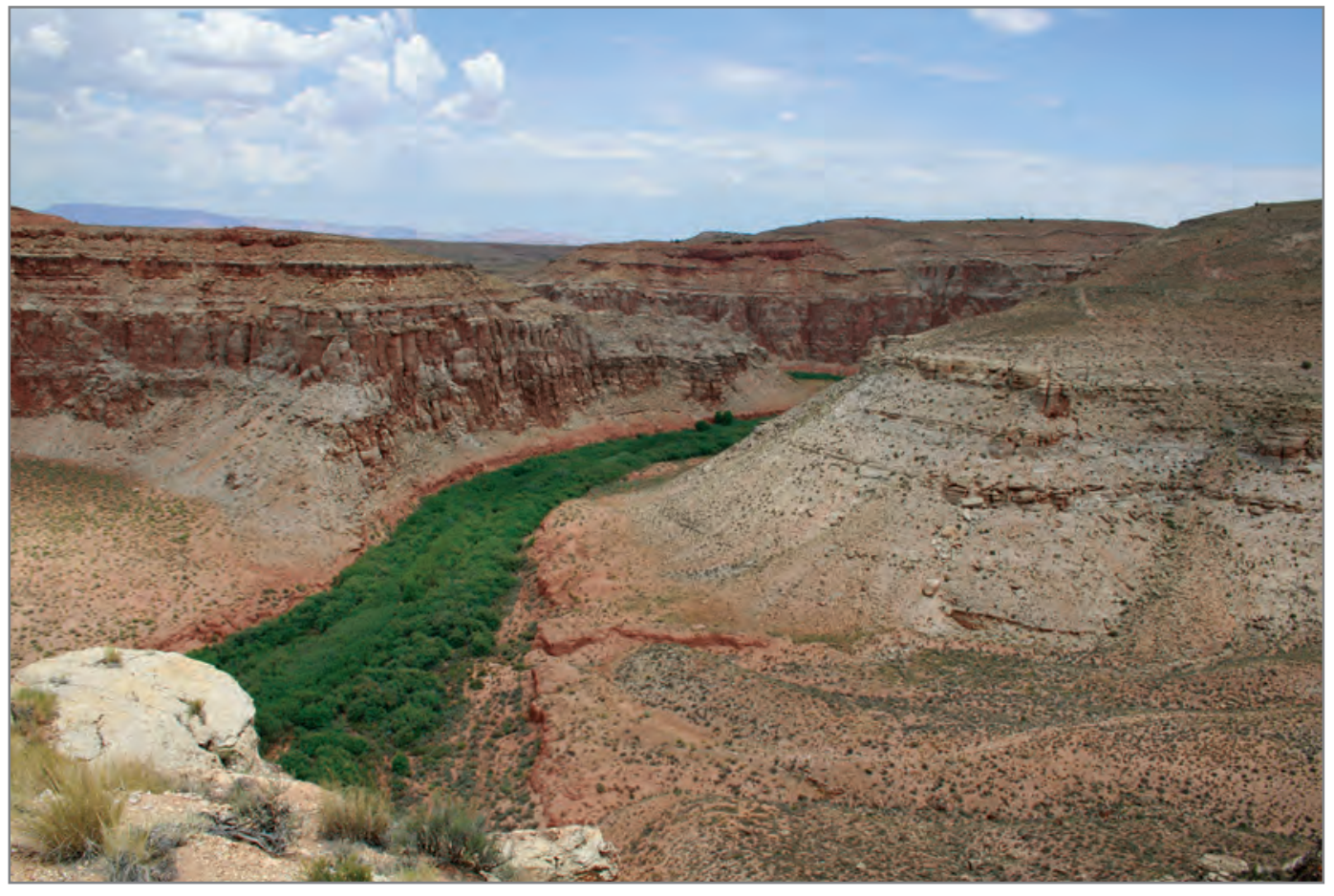

Kanab Basin looking north. Photograph by Robert J. Hart, U.S. Geological Survey. 


\title{
Chapter F
}

\section{Assembling a Virtual "Weevils of North America" Checklist with Symbiota-Preliminary Insights}

\author{
By Nico M. Franz, ${ }^{1}$ Charles W. O'Brien, ${ }^{1}$ Sarah D. Shirota, ${ }^{1}$ Michael T. Shillingburg, ${ }^{1}$ Chelsey R. Tellez, ${ }^{1}$ and \\ Edward E. Gilbert ${ }^{1}$
}

\section{Abstract}

We report on preliminary insights gained from the virtual Weevils of North America (WoNA) project. WoNA represents a novel, collaborative solution to the challenge of assembling monographs for taxonomically complex groups such as the weevils (Coleoptera: Curculionoidea) by leveraging the large-scale, specimen-level digitization efforts of thematic collections networks. The project has been developed online since 2012 within the framework of the Southwest Collections of Arthropods Network (SCAN). Current WoNA holdings include voucher-based data on more than 350 genera and 1,100 species, as well as high-resolution images for more than 600 species. Efforts to enrich these data with additional images, taxon profile pages, and interactive identification keys are underway. SCAN and WoNA are supported by the Symbiota software platform, which promotes diversified forms of engagement with research collections, taxonomic experts, and the general user community. In each case, the sources and actions related to data holdings are properly accredited. Future Symbiota modules will facilitate an increasingly monograph-like representation and publishable output under this approach. Integration of Filtered Push technology allows external users to submit annotations amounting to an open, distributed, and dynamic system of peer review that can increase support and trust in such virtual taxonomic knowledge environments.

\section{Introduction}

The natural history collections community is making a strong push to bring specimen data online at a global scale. Specimen-based monography is transitioning from traditional, one-time publication in print media to the continuous assembly of dynamic, virtual environments (Smith, 2014). Large-scale investments in biodiversity data

${ }^{1}$ Arizona State University mobilization, in North America and elsewhere, are shifting the landscape (Baker, 2011). Such game-changing initiatives include the National Science Foundation's Advancing Digitization of Biological Collections program (National Science Foundation, 2011) and the iDigBio HUB, which jointly sustain 15 Thematic Collections Networks (TCNs) that have been initiated since 2011. The mobilization of virtual collections for research and outreach is also a central objective of the Network Integrated Biocollections Alliance and related initiatives (Wheeler and others, 2012; Hanken, 2013; Hardisty and others, 2013).

Digitization of specimen data, though, requires systematic synthesis and discovery in order to be useful on a broad scale. Natural history collections require continuous growth and curation to best serve diverse user communities (Drew, 2011; Johnson and others, 2011). Curation, in turn, requires the time of taxonomic experts who are distributed across many institutions and must also respond to pressures to produce peer-reviewed and highly cited research (Valdecasas, 2011). Thus digitization finds itself at a crossroads where taxonomic experts are presented with stark choices: data quantity versus quality; build-up of research-supporting infrastructure versus genuine research and innovation; publication in online databases versus highly ranked journals (Wägele and others, 2011; Costello and others, 2013). Moreover, trust in data quality is at the top level of the Semantic Web stack - the hierarchy of languages and logic operations for research queries - that specimen data sustain at lower levels (Berners-Lee and others, 2006). To earn that trust and maximize return on investment, we must offer experts new incentives to engage in the virtual curation of digitized specimen data (Vollmar and others, 2010).

Numerous efforts to bridge the divide between digitization of specimen data and accredited publication are underway (for example, Smith and others, 2013). Here we offer preliminary insights into one such effort intended to create a new model of collaborative virtual monography for a major lineage of North American insects - the weevils. The Weevils of North America (WoNA) project (http:// symbiota4.acis.ufl.edu/scan/portal/checklists/checklist. 
php?cl=1) is the first to build directly upon an NSFsupported TCN, that is, SCAN— the Southwest Collections of Arthropods Network (http://symbiota4.acis.ufl.edu/scan/ portal/). SCAN came online in mid-2012 and has since (as of October 2015) accumulated $\sim 6$ million specimen occurrence records representing 66,000 arthropod species (including GBIF records and moth observations which are also hosted in SCAN), primarily from North America. Of these specimen records, approximately 75 percent are georeferenced with latitude/longitude data; about 50 percent of the records are identified to the level of species.

SCAN and WoNA are hosted by the iDigBio HUB server infrastructure and sustained by the innovative, open source, and exclusively Web-based Symbiota software platform (http://symbiota.org). Symbiota facilitates the bottom-up assembly of voucher-based biodiversity information communities — called portals — of which the Southwest Environment Information Network (SEINET; Http:// swbiodiversity.org/portal/index.php) is a primary example.

In the past 5 to 10 years, floristic treatments within SEINet have matured into monograph-like resources of high information density and accessibility (Makings, 2006; see also http://symbiota.org). Such treatments include abundantly vouchered and searchable species lists, species profile pages with high-resolution images and descriptive data, interactive occurrence maps, and dynamic keys to identify taxa based on checklist- or map-driven entry points. Hence, many components for delivering a Symbiota-based WoNA monograph are already in place, as are platform-inherent advantages related to the continuous expansion, annotation, and enhancement of checklists by contributors and users.

Our interim review of WoNA assembly includes special taxonomic challenges related to weevils, an overview of Symbiota's design principles and checklist support functions, current data holdings, and future developments. Throughout, our motivation is to further promote this approach for adoption by other arthropod research communities.

\section{Taxonomic Challenges and Opportunities}

Weevils - Coleoptera: Curculionoidea, in the sense of Bouchard and others (2011) - are among the most diverse, economically impactful, and taxonomically challenging lineages of arthropods globally (Oberprieler and others, 2007) and particularly in North America (herein limited to Canada and the United States). Weevils are ubiquitous in all terrestrial habitats where they are herbivores of native or cultivated plants as well as premier control agents (O'Brien, 1995). Anderson's (2002) synopsis and other curculionoid treatments in American Beetles (Arnett and others, 2002) account for 7 families with 317 genera and 2,728 species in the region. The fungus-cultivating bark and ambroisa beetles (Harrington, 2005), which are members of the superfamily Curculionoidea (Kuschel, 1995), add at least 77 more genera and 532 more species to this diversity (Rabaglia, 2002). Managing such richness is challenging enough when taxonomic groups are well circumscribed, but in weevils this challenge is further amplified by an unnatural and impenetrable mid-level classification that limits the recognition of monophyletic lineages.

The taxonomic history of the weevil superfamily can be abridged into (1) a period of foundation laying by 19th-century authors such as Schoenherr (Schoenherr, 1823, 1826, 18331845) and Lacordaire (Lacordaire and Chapuis, 1863, 1866), and (2) a prolonged period of incremental extensions of that basic framework throughout the 20th century. It is well known that Lacordaire's definitions of weevil groups (Lacordaire and Chapuis, 1863, 1866) are too simplistic to yield natural taxon circumscriptions (Kuschel, 1995; Anderson, 2002; Oberprieler and others, 2007). Nevertheless, these definitions remain highly influential in modern classifications (Alonso-Zarazaga and Lyal, 1999), which recognize some 16 subfamilies, 195 tribes, and 5,800 genera in the Curculionidae alone (again, excepting bark beetles). Molecular projects conducted over the past 15 years, (for example, Farrell, 1998; McKenna and others, 2009; Bocak and others, 2014) have under-sampled this diversity so dramatically as to yield only minimal classificatory realignments (Franz and Engel, 2010).

The Weevils of North America project represents a novel, bottom-up effort that emphasizes specimen-level data and phenotype-based taxonomy and thus critically complements parallel top-down phylogenetic efforts. Past decades have shown that major advances in weevil systematics exceed the abilities of individual researchers. No fruitful synthesis is possible unless both bottom-up and top-down components are covered and coordinated. Hence we require a better structured and distributed research and synthesis platform that (1) is up to date with developments and standards in biodiversity informatics and (2) can utilize these tools to scale up to the vast dimensions of the task.

\section{Symbiota Design Principles}

\section{Thematic Collections Networks Increase Information Quality Control}

Symbiota portals provide a framework for collaboratively publishing biodiversity information. Regional checklists are built upon vouchered records with direct linkages to the sources that manage the data and specimens (fig. 1). This ensures that data updates undertaken within the source collections can flow back to the virtual checklists, and vice versa (Vollmar and others, 2010).

Symbiota portals adhere to a particular regional and (or) taxonomic theme and scope. A portal's full potential may be reached if it is supported on a broad scale among numerous 
Home $\gg$ Weevils of North America (WoNA)

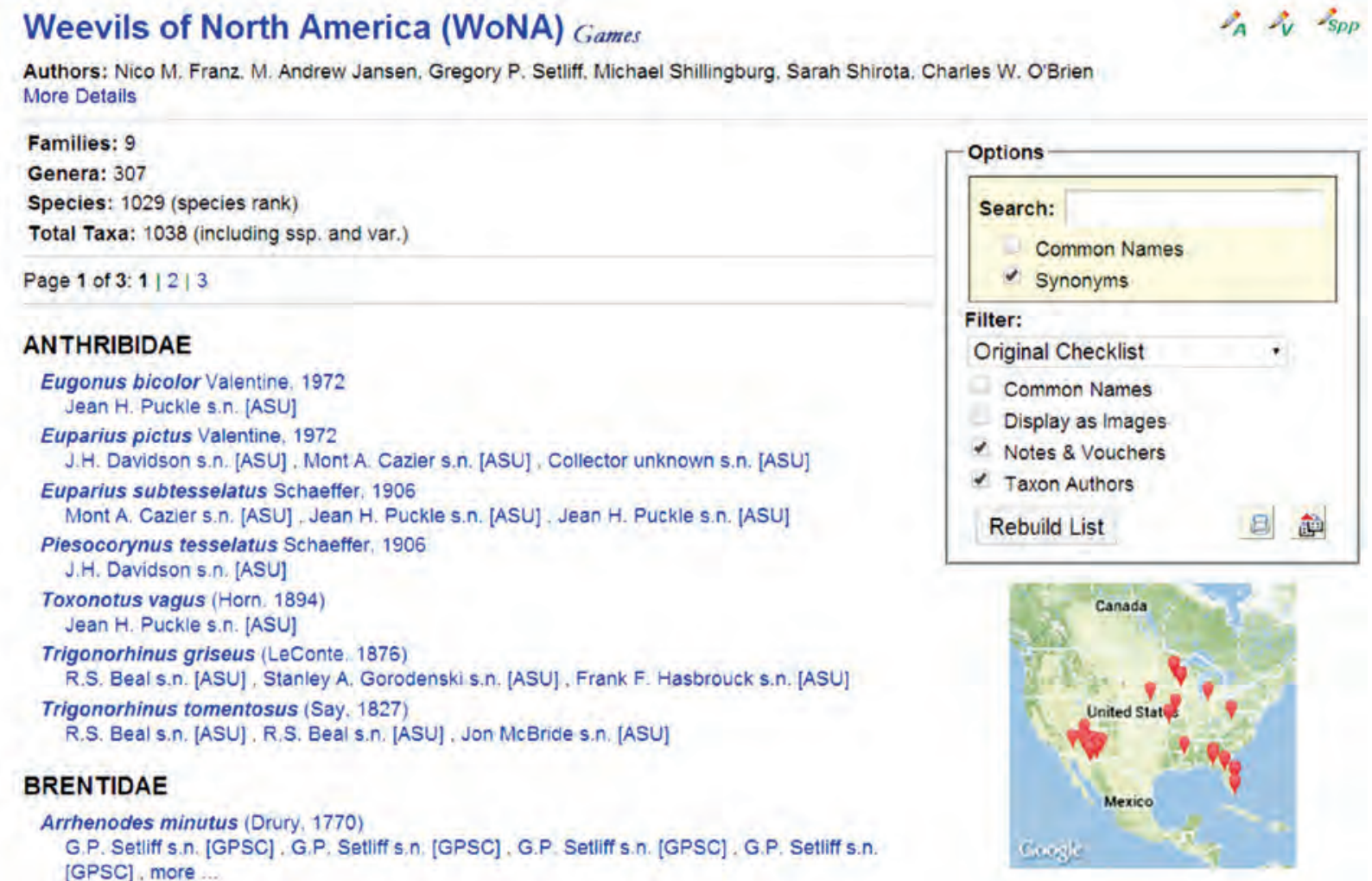

Figure 1. Screenshot of Weevils of North America checklist homepage in SCAN (Southwest Collections of Arthropods Network), showing current occurrence record statistics (as of January 2014) and taxa with the "Taxon Authors" and "Notes \& Vouchers" options activated (see checkmarks in the Options/Filter box). Specimens are annotated with their collector and source collection (displayed in square brackets). The Options/Filter box includes a search function (with synonymy) to further narrow down the taxon list, as well as print and spreadsheet output options (icons to the right of "Rebuild List"). The top right corner includes icons for checklist administration ("A"), managing linked vouchers ("V"), and adding species ("Spp").

thematically interconnected data contributors. Portals promote a positive feedback loop that includes (1) making data public instantaneously, which can serve to expose errors; (2) using Web-based editing tools and workflows that allow such errors to be resolved as they are identified; (3) redirecting data repairs back to a source's internal platform; and (4) rendering repairs permanent with the subsequent data update. Thus, Symbiota takes advantage of the themed data mobilization approach towards improving the quality of the individual collections' datasets (Costello and others, 2013).

\section{Portals Promote Diversified Forms of Engagement}

Symbiota portals allow different forms of engagement for contributing collections, research teams, individual experts, and public groups or citizens. In particular, collections and researchers have the option to contribute specimen information through either direct "Live Data" management or a "Data Snapshot" harvested periodically from another database system. In the former case, Symbiota's content management system (CMS) is used to achieve day-to-day digitization and data assembly tasks, whereas in the latter case the portal merely exposes information generated in another (preferred) environment. Symbiota has features to allow for such flexibility, including manual or API-supported data uploads using Darwin Core-compliant formats (Wieczorek and others, 2012). In addition, any user can readily access a portal's occurrence records by downloading auto-configured datasets in spreadsheet format. Users can submit comments to data owners following a simple login procedure. Jointly these features lower the threshold for engaging new member collections and taxonomic experts.

\section{Functional Modularity, Data Integrity, and Customization}

Symbiota allows communities to acquire distinct identities and functions while ensuring database integrity at a broad scale. The aim to integrate biodiversity information sets practical strictures on the degree to which configurations 
can vary. These limitations are most apparent in the format of the single occurrence data table (fig. 2), which is linked to a portal's taxonomic thesaurus. The latter constitutes a continuously curated reference classification that subtends all taxonomically based search functions and output displays. Joining a Symbiota portal requires acceptance and coordination of these conventions (Scoble, 2004; Franz and others, 2008).

Beyond sharing data formats, Symbiota portals are customizable in numerous ways that suit specific community needs. Modularity is manifested at different levels: (1) application modularity - the modules for managing specimens, biotic inventories, identification keys, and taxon profile pages are designed to function independently of one another; (2) data modularity-collections are represented as independent units with their own management regimes; and (3) portal modularity - multiple Symbiota portals can maintain distinct front-end appearences while connecting to a single back-end database.

Modularity also means that existing Web services can be deployed while optimizing for specific functions. For instance, services related to mapping occurrence records are provided through Google Maps (https://maps.google.com/). Georeferencing tasks are supported by GEOLocate tools (Rios and Bart, 2010). Voucher images can be imported from external sites such as the Encyclopedia of Life (Wilson, 2003).

\section{Checklist Assembly Functions-A Primer}

We limit our Symbiota review to the creation of "static" checklists, created by single or collaborating experts on top of baseline digitizations efforts (see also http://symbiota. org/docs/research-species-lists/). WoNA exemplifies this collaborative checklist model.

\section{Biotic Inventories}

Once a portal and member collection nodes are established, contributing experts can create regional checklists by either creating a species list within the network or by linking a group of species lists within a Symbiota project. Static checklists give researchers complete and continuous control over species composition, taxonomic placements, region specific comments, and voucher assignments. Additional partitioning of an all-inclusive list into multiple smaller lists - for example, for states, counties, or conservation areas - is also possible.

Symbiota offers a flexible user interface for exploring checklists (fig. 1). Users can filter these lists by taxon and display results with author names, habitat information, and (or) voucher details. Checklists can also be displayed as a set of thumbnail images, thus making it easier to visualize the taxa represented in the region (fig. 3).

\section{Interactive Keys}

Symbiota's interactive keys are generated directly from descriptive data stored in a relational DELTA (description language for taxonomy) format (see http://delta-intkey. com/). Such keys have many advantages over traditional dichotomous keys (Hagedorn, 2007; Brach and Boufford, 2011). Computerized identification tools have advanced to the point where specifying only two to five characters often reduces a long list of candidate taxa to a manageable size. Subsequent browsing of taxon images, distribution maps, and descriptions can further speed up the process.

The Symbiota key-editing interface is coordinated with the hierarchy defined within the taxonomic thesaurus, allowing for character inheritance and other efficient coding tools. If a large region or taxonomic group is treated, keys are usually broken down into several levels of complexity, and the user proceeds from one key to the next.

\section{Taxon Profile Pages}

Symbiota offers taxon profile pages that complement the aforementioned modules (fig. 4). Natural language descriptions as well as images may be provided for each taxon. An occurrence map generator pulls information from the collections records to produce a distribution map. The corresponding CMS includes separate tabs to (1) provide synonyms and vernacular names; (2) view all annotated images; (3) specify the sequence in which images appear; (4) add new images; and (5) add natural language description(s) or notes on natural history and distribution. Links to source repositories for primary taxonomic literature such as the Biodiversity Heritage Library (http://www.biodiversitylibrary. org/) are supported.

\section{Checklist Management}

Symbiota's CMS for checklist management (fig. 5) allows lead authors to manage contributor access rights and related checklists, add new taxa and images, and link new vouchers based on dynamic searches. Tabs to resolve conflicting voucher identifications and output reports round out the checklist CMS.

\section{Current WoNA Holdings}

From its beginnings in 2012, WoNA has been exclusively Symbiota-based (fig. 1). The project has benefitted from donations of authoritatively identified specimens of the Charles W. O'Brien (CWOB) collection (Green Valley, Arizona; see O'Brien and Wibmer, 1982; fig. 2). In October 2015, searches for North American curculionoids in SCAN yielded $>43,500$ specimens and $>1,800$ species; the results showed a strong Southwest 
Arizona State University Hasbrouck Insect Collection (ASU:ASUHIC) Home $\gg$ Collection Wanagement $\gg$ Editor

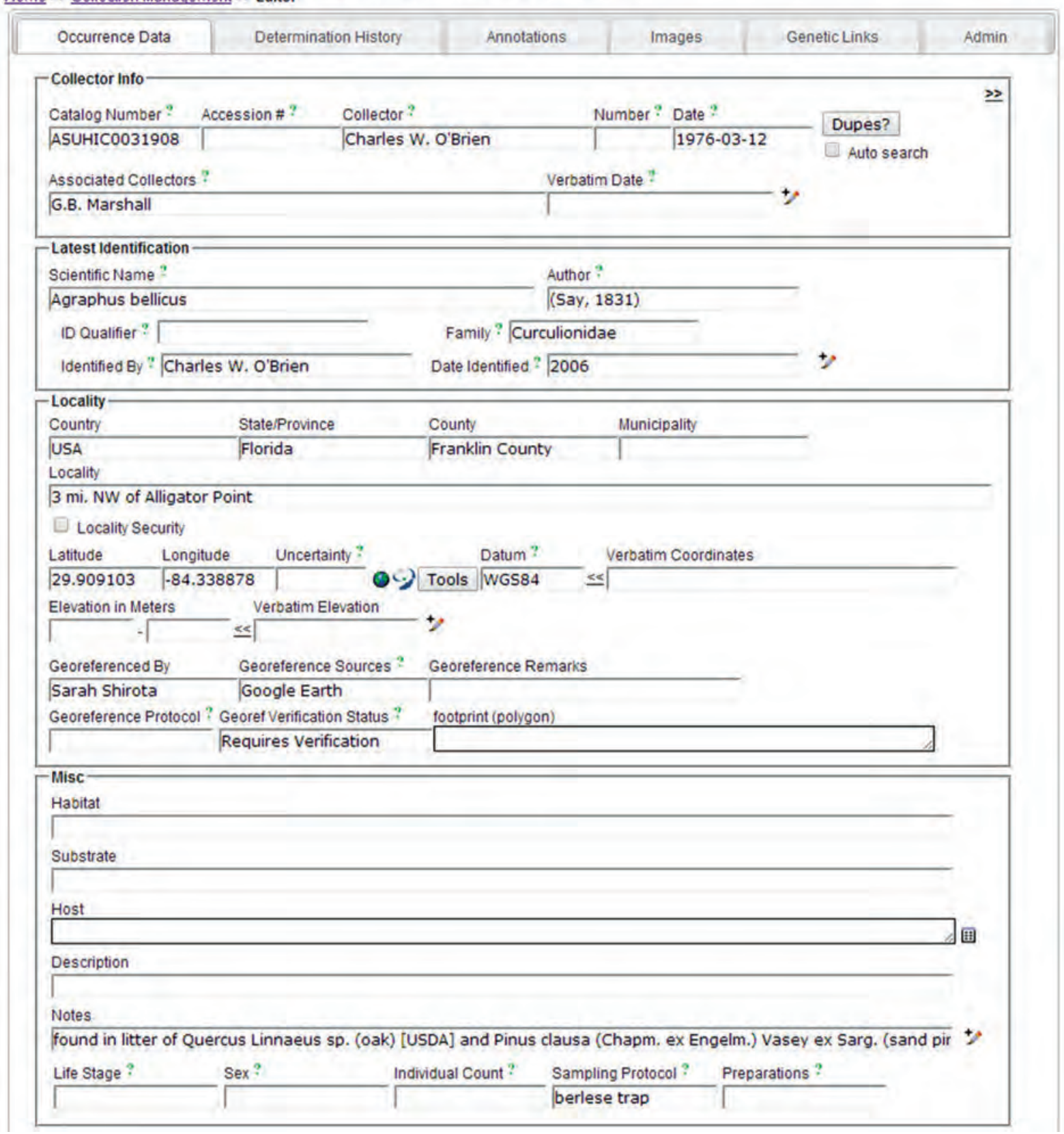

Figure 2. Screenshot of one record in the SCAN (Southwest Collections of Arthropods Network) occurrence data table (see also http://symbiota.org/docs/symbiota-occurrence-data-fields-2/). Top-level tabs include screens for editing the specimen's identification (with options to submit to Filtered Push; see "Conclusions" section below), viewing annotations, adding images or GenBank links, and occurrence record administration. Switching from frontend (fig. 1) to back-end (fig. 2) displays of specimen-level data is instantaneous in Symbiota for users with editing rights. 


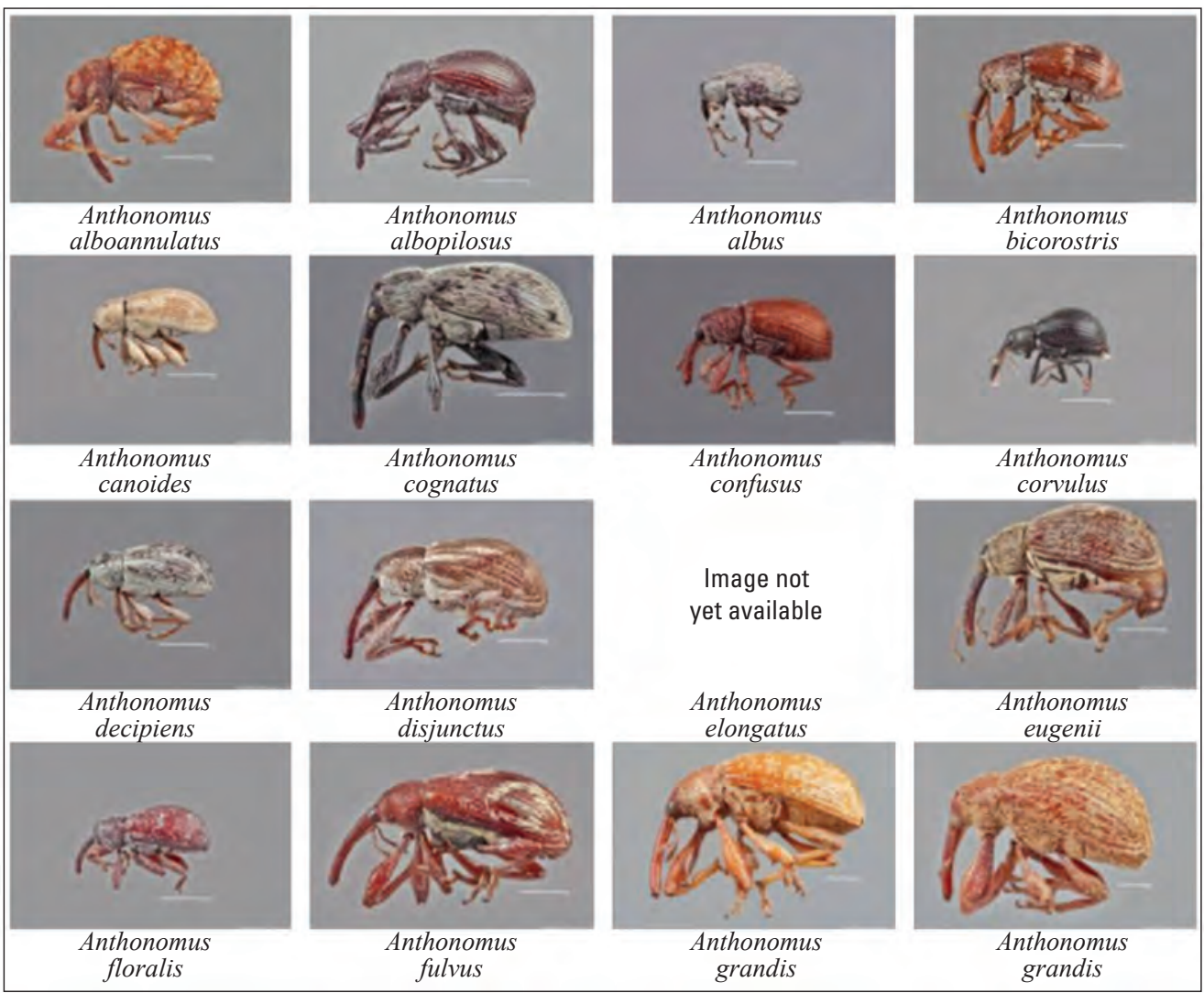

Figure 3. Screenshot with thumbnail view of species in the weevil genus Anthonomus Germar (in the sense of O'Brien and Wibmer, 1982) linked to WoNA. This view is produced by searching for "Anthonomus" in the checklist's Search/Filter box (fig. 1) and then selecting "Display as Images" and "Rebuild List". Clicking on each thumbnail will lead to the corresponding taxon profile page, where additional high-resolution images and specimen data are available.

Acalles sablensis Blatchley, 1920 s

Family: Curculionidae

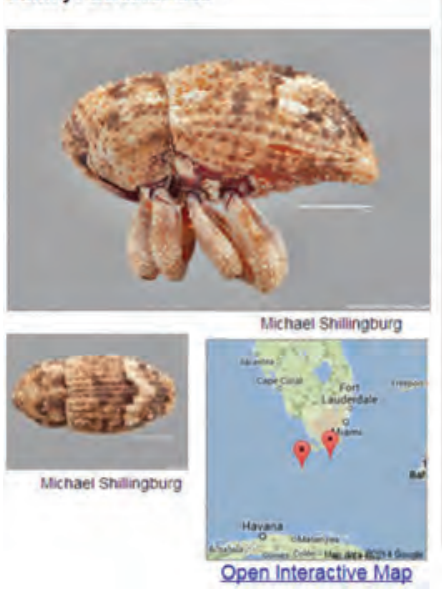

Description

Blatchley. 1920.

Oval, robust. Dark reddish-brown, above densely clothed with dirty gray, white and fuscous scales; the white ones forming a vague stripe each side and a quadrate spot at middle of base of thorax, and a broad common V-shaped blotch on the declivity of elytra; this bordered in front by an irregular cross band of fuscous scales, these also forming several scattered blotches on disk of thorax and basal half of elytra and a broad common one on middle of declivity. Under surface thickly clothed with round white scales. Beak broad, flattened, subspatulate, about as long as thorax, naked except at base, finely and sparsely punctate, carinate on basal third. Thorax slightly broadfer than long, strongly narrowed and broadly constricted in front of middle, sides rounded. Sculpture concealed, disk with numerous scattered, very short forward-inclined setae. Elytra oval, one-fourth wider at base than thorax, sides parallel to abical third. thence araduallv converaina to the coniointlv rounded

Figure 4. Screenshot of species profile page in the Southwest Collections of Arthropods Network/Weevils of North America database for Acalles sablensis Blatchley, with link to the original description (Blatchley, 1920), available through the Biodiversity Heritage Library. Thumbnails of dorsal and lateral habitus photographs and an interactive map of specimen occurrence records are also shown on each species page. The pen icon in the top right corner links to the taxon profile page content management system (see fig. 5). 
bias mirroring that of the source collections (that is, $\sim 10,000$ specimens and 400 species are from Arizona alone). WoNA itself has 1-100 specimen occurrence records for $>350$ genera ( $\sim 88$ percent genus-level coverage for North America) and $>1,100$ species ( $\sim 30$ percent species-level coverage for North America). High-resolution images (frequently with a scale bar) are available for more than 600 species ( $15-20$ percent; fig. 3 ). Roughly 300 diagnoses, imported from the Biodiversity Heritage Library, have been added to WoNA (fig. 4). The following URL for the cryptorhynchine genus Acalles Schoenherr (in the sense of O'Brien and Wibmer, 1982) illustrates how these components are integrated in Symbiota: http://symbiota4.acis.ufl.edu/scan/ portal/taxa/index.php?taxon $=4682$.

WoNA's interactive key module is available at http:// symbiota4.acis.ufl.edu/scan/portal/ident/key.php?cl=1. Basic functionality of this module is projected for late 2015 although authoring a powerful tool will require considerable new taxonomic research. The SCAN identification module will include a new feature that allows authors to illustrate specific characters by way of voucher-based, scalable vector graphics (SVG)-highlighted detail images (Ramírez and others, 2007;
Yoder and others, 2010). So far, 50 multi-state characters for curculionoid families and subfamilies have been extracted from the American Beetles chapters (Anderson, 2002; Arnett and others, 2002) and reformulated for the WoNA key.

\section{Conclusions-Prospects for Arthropod-Centric Symbiota Monographs}

We close with discussing a broader question-what are the advantages and limitations of the WoNA approach to systematic "monography," and under what circumstances should prospective authors make use of this approach?

Mayr and Ashlock (1991, p. 421) define a monograph as "an exhaustive treatment of a higher taxon in terms of all available information pertinent to taxonomic interpretation; [this] usually involves full systematic treatment of the comparative anatomy, biology, ecology, and detailed distributional analyses of all included taxa." While WoNA
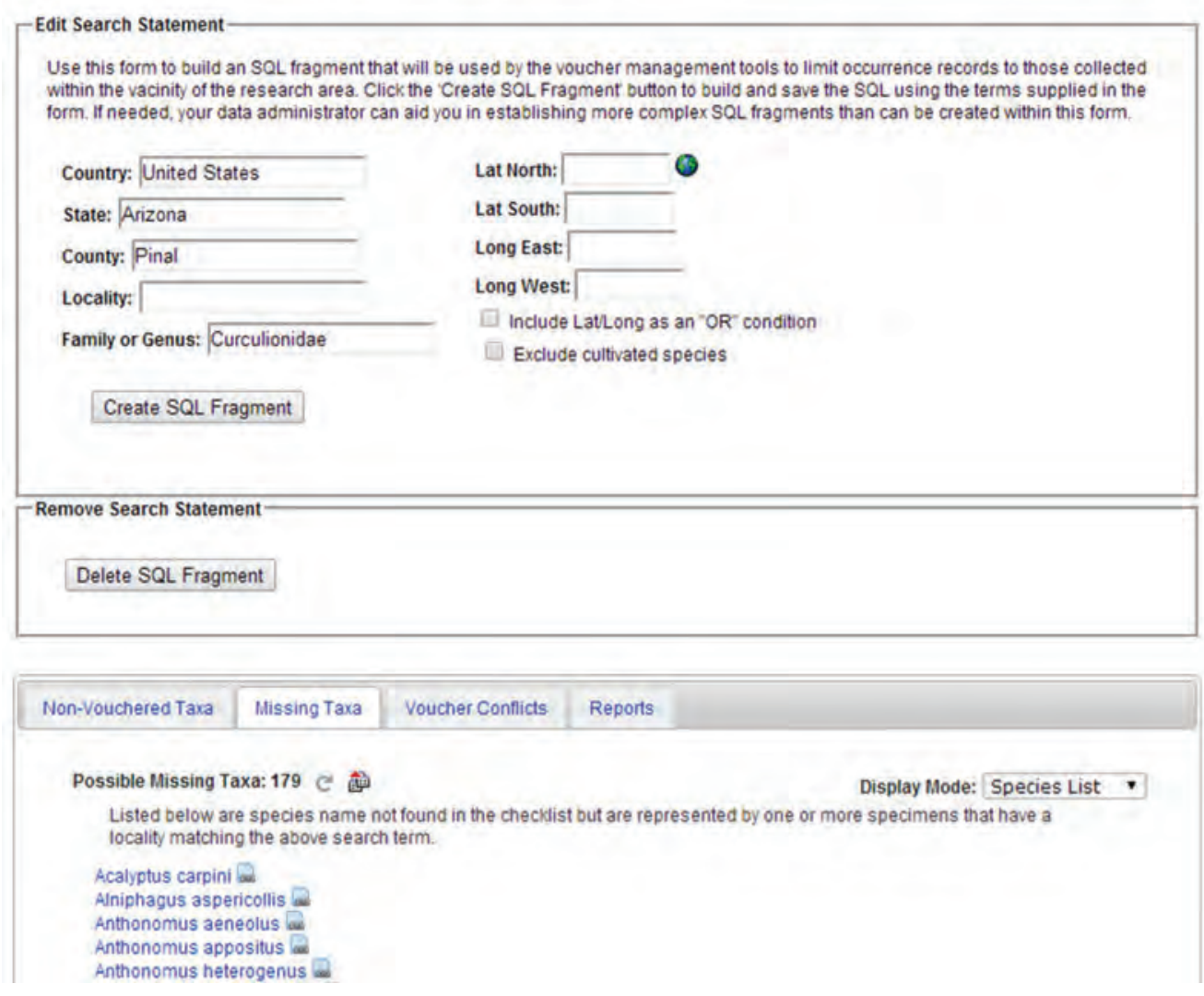

Figure 5. Screenshot of Weevils of North America checklist administrator interface for managing linked vouchers. Checklist authors can create custom searches ("Create SQL Fragment") to identify vouchers recently added to the Southwest Collections of Arthropods Network as potential candidates for inclusion in the checklist. 
fits this definition in a general sense, we acknowledge that publishing by way of Symbiota is not identical to a one-time submission of a manuscript to a traditional, peer-reviewed journal. Academic recognition of new and significant systematic contributions in such a medium is arguably the greatest challenge.

However, the landscape of acceptable models for publishing taxonomic information is changing (International Commission on Zoological Nomenclature, 2012; Smith and others, 2013; Smith, 2015). There are many advantages inherent in shifting to a dynamic, collaborative monography model—especially for a project of WoNA's dimensions. For one, Symbiota - as a result of prior NSF awards and strong iDigBio/TCN community support (Gries and others, 2014) - is an immensely robust, production-level platform with some 470 collections, 2,000 users, and 18 million specimen occurrence records managed in more than 20 portals including SCAN. SEINet alone has $\sim 20,000$ monthly site visits, according to Google Analytics. Such widely distributed data input and institutional/user support are valuable assets to taxonomist authors. Additional synergy may be obtained through linking WoNA with the nationwide network of Symbiota vascular plant portals. Connecting weevil and plant specimen data at such a scale opens up new possibilities for analyses of co-occurrences and interactions.

Symbiota's capabilities to support monographic treatments can be further improved with new modules that allow (1) the citable exposition (author/year/reference URL) of Symbiota monographs within existing portals; (2) custom-configurable (taxon-/region-specific) static output functions (for example, extract the checklist as a PDF; show taxa, images, and key for Arizona); and (3) a standard-compliant reference module for taxon profile pages. These modules can mature as WoNA and similar treatments receive more authoritative input and weight. Integration with ZooBank (Krell and Pyle, 2010) would open up possibilities for publishing new nomenclatural actions.

Another advantage is the ability to accommodate different forms of institutional and author engagement with proper intellectual attribution. This allows WoNA to transparently accredit the provenance of each specimen, image, description, or key identification component (figs. 1 and 4). Attribution of credit is critical for engaging additional collections and experts into such collaborative projects.

Lastly, Symbiota is developing tools to promote peer review by way of expert annotations using the novel Filtered Push technology (Morris and others, 2013), see http://wiki.filteredpush.org/wiki/. This technology amounts to an open, distributed, and dynamic system of contributor engagement and peer review. The coming years will reveal to what extent these developments contribute to altering the cost/benefit ratio for taxonomic experts interested in leveraging large-scale specimen-level digitization efforts towards monographic projects with Symbiota.

\section{Acknowledgments}

The authors thank Neil Cobb and Paul Heinrich of Northern Arizona University for their support of the SCAN and WoNA projects. We also acknowledge contributions to WoNA's data holdings by Gregory Setliff (Kutztown University), Martha Camacho, Dustin Daniel, Nicole Henry, Soon Flynn, Jennifer Guzzardi, Lisa Höfler, Andrew Jansen, Sangmi Lee, Joshua Persson, and Naomi Pier (all Arizona State University). Support for WoNA-related digitization and research activities by the National Science Foundation (EF-1207107) and the United States Department of Agriculture (Agreement 58-12751-335) is kindly acknowledged.

\section{References Cited}

Alonso-Zarazaga, M.A., and Lyal, C.H.C., 1999, A world catalogue of families and genera of Curculionoidea (Insecta: Coleoptera) (exceptiong Scolytidae and Platypodidae): Barcelona, Spain, Entomopraxis, S.C.P. Edition, 315 p., [Also available online at http://weevil.info/sites/weevil. info/files/Alonso-Zarazaga\%20\%26\%20Lyal,\%201999_ World\%20Catalogue $\% 20 \% 28$ searchable $\% 29$.pdf.]

Anderson, R.S., 2002, Family 131-Curculionidae, in Arnett, R.H., Jr., Thomas, M.C., Skelley, P.E., and Frank, H., eds., American beetles - Polyphaga - Scarabaeoidea to Curculionoidea, v. II: Boca Raton, Florida, CRC Press, p. 722-815.

Arnett, R.H., Jr., Thomas, M.C., Skelley, P.E., and Frank, H., eds., 2002, American beetles-Polyphaga-Scarabaeoidea to Curculionoidea, v. II: Boca Raton, Florida, CRC Press, 861 p.

Baker, B., 2011, New push to bring US biological collections to the world's online community-Advances in technology put massive undertaking within reach: BioScience, v. 61 , no. 9 , p. 657-662, http://dx.doi.org/10.1525/ bio.2011.61.9.4.

Berners-Lee, T., Hall, W., Hendler, J.A., O'Hara, K., Shadbolt, N., and Weitzner, D.J., 2006, A framework for web science: Foundations and Trends in Web Science, v. 1, no. 1, p. 1-130, http://dx.doi.org/10.1561/1800000001.

Blatchley, W.S., 1920, Some new Rhynchophora from eastern North America with additions to and corrections of the "Rhynchophora of northeastern America": Journal of the New York Entomological Society, v. 28, no. 2, p. 161-178, accessed October 25, 2015, at https://archive.org/details/ jstor-25003893.

Bocak, L., Barton, C., Crampton-Platt, A., Chester, D., Ahrens, D., and Vogler, A., 2014, Building the Coleoptera tree-of-life for $>8000$ species - Composition of public DNA data and fit with Linnaean classification: Systematic Entomology, v. 39, no. 1, p. 97-110, http://dx.doi. org/10.1111/syen.12037. 
Bouchard, P., Bousquet, Y., Davies, A.E., Alonso-Zarazaga, M.A., Lawrence, J.F., Lyal, C.H.C., Newton, A.F., Reid, C.A.M., Schmitt, M., Ślipiński, S.A., and Smith, A.B.T., 2011, Family-group names in Coleoptera (Insecta): Zookeys, v. 88, p. 1-972, http://dx.doi.org/10.3897/zookeys.88.807.

Brach, A.R., and Boufford, D.E., 2011, Why are we still producing paper floras?: Annals of the Missouri Botanical Garden, v. 98, no. 3, p. 297-300, http://dx.doi.org/10.3417/2010035.

Costello, M.J., Michener, W.K., Gahegan, M., Zhang, Z.-Q., and Bourne, P.E., 2013, Biodiversity data should be published, cited, and peer reviewed: Trends in Ecology and Evolution, v. 28, no. 8, p. 454 -461, http://dx.doi.org/10.1016/j.tree.2013.05.002.

Drew, J., 2011, The role of natural history institutions and bioinformatics in conservation biology: Conservation Biology, v. 25, no. 6, p. 1250-1252, http://dx.doi.org/10.1111/j.15231739.2011.01725.x.

Dybas, C., 2011, NSF awards grants to advance digitization of biological collections: National Science Foundation press release 11-136, accessed October 25, 2015, at http://www. nsf.gov/news/news_summ.jsp?cntn_id=121015.

Farrell, B.D., 1998, "Inordinate fondness" explained-Why are there so many beetles?: Science, v. 281, no. 5376, p. 555-559, http://dx.doi.org/10.1126/science.281.5376.555.

Franz, N.M., and Engel, M.S., 2010, Can higher-level phylogenies of weevils explain their evolutionary success? A critical review: Systematic Entomology, v. 35, no. 4, p. 597-606, http://dx.doi.org/10.1111/j.1365-3113.2010.00534.x.

Franz, N.M., Peet, R.K., and Weakley, A.S., 2008, On the use of taxonomic concepts in support of biodiversity research and taxonomy, in Wheeler, Q.D., ed., The new taxonomy, Systematics Association Special Volume Series 74: Boca Raton, Florida, Taylor and Francis, p. 63-84, accessed October 25, 2015, at http:/www.biology.uprm.edu/facultad/ publications/Nico_Franz_20070701_.pdf.

Gries, C., Gilbert, E.E., and Franz, N.M., 2014, SymbiotaA virtual platform for creating voucher-based biodiversity information communities: Biodiversity Data Journal, v. 2, no. e1114. [Also available online at http://dx.doi.org/10.3897/ BDJ.2.e1114].

Hagedorn, G., 2007, Overview of interactive keys: Richmond, Surrey, UK, Kew Interactive Key Forum, Royal Botanic Gardens Herbarium, accessed October 25, 2015, at https:// kikforum.wordpress.com/2007/01/12/overview-of-interactive-keys-provided-by-gregor-hagedorn/.

Hanken, J., 2013, Biodiversity online-Toward a network integrated biocollections alliance: BioScience, v. 63, no. 10, p. 789-790, http://dx.doi.org/10.1525/bio.2013.63.10.4.

Hardisty, A., Roberts, D., and The Biodiversity Informatics Community, 2013, A decadal view of biodiversity informatics - challenges and priorities: BMC Ecology, v. 13, p. 1-16, http://dx.doi.org/10.1186/1472-6785-13-16.
Harrington, T.C., 2005, Ecology and evolution of mycophagous bark beetles and their fungal partners, in Vega, F.E., and Blackwell, M., eds., Ecological and evolutionary advances in insect-fungal associations: New York City, Oxford University Press, p. 257-291, accessed October 25, 2015, at http://www.public.iastate.edu/ tcharrin/ Mycophagy4\%2009.pdf.

International Commission on Zoological Nomenclature, 2012, Amendment of Articles 8, 9, 10, 21 and 78 of the international code of zoological nomenclature to expand and refine methods of publication: Zookeys, v. 219, no. 3, p. 1-10, http://dx.doi.org/10.3897/zookeys.219.3944.

Johnson, K.G., Brooks, S.J., Fenberg, P.B., Glover, A.G., James, K., Lister, A.M., Michel, E., Spencer, M., Todd, J.A., Valsami-Jones, E., Young, J.R., and Stewart, J.R., 2011, Climate change and biosphere response-Unlocking the collections vault: BioScience, v. 61, no. 2, p. 147-153, http://dx.doi.org/10.1525/bio.2011.61.2.10.

Krell, F.-T., and Pyle, R.L., 2010, ZooBank progress report: Bulletin of Zoological Nomenclature, v. 67, no. 4, p. 271-275, accessed October 25, 2015, at https:/www.dmns. org/media/324395/163-bullzoolnom2010.pdf.

Kuschel, G., 1995, A phylogenetic classification of Curculionoidea to families and subfamilies: Memoirs of the Entomological Society of Washington, v. 14, no. 5-33.

Lacordaire, T., and Chapuis, F., 1863, Histoire naturelle des insectes-Genera des coléoptères ou exposé méthodique et critique de tous les genres proposés jusqu'ici dans cet ordre d'insectes, v. 6: Paris, Roret, accessed October 25, 2015, at http://babel.hathitrust.org/cgi/pt?id=mdp.39015042678444; view=1 up;seq=7.

Lacordaire, T., and Chapuis, F., 1866, Histoire naturelle des insectes-Genera des coléoptères ou exposé méthodique et critique de tous les genres proposés jusqu'ici dans cet ordre d'insectes, v. 7: Paris, Roret, accessed October 25, 2015, at http://babel.hathitrust.org/cgi/pt?id=ucm.530739302x; view $=1$ up;seq $=9$.

Makings, E., 2006, San Pedro riparian national conservation area checklist -Flora of the San Pedro riparian national conservation area: SEINet, Arizona chapter, accessed October 25, 2015, at http://swbiodiversity.org/seinet/checklists/ checklist.php?cl=3.

Mayr, E., and Ashlock, P.D., 1991, Principles of systematic zoology, 2d ed.: New York, McGraw Hill, Inc., accessed October 25, 2015, at http://bug.tamu.edu/entocourses/ ento601/pdf/Mayr_Ashlock_chapter_2.pdf.

McKenna, D.D., Sequeira, A.S., Marvaldi, A.E., and Farrell, B.D., 2009, Temporal lags and overlap in the diversification of weevils and flowering plants: Proceedings of the National Academy of Sciences of the United States of America, v. 106, no. 17, p. 7083-7088, accessed October 25, 2015, at http://www.pnas.org/content/106/17/7083.full.pdf. 
Morris, R.A., Dou, L., Hanken, J., Kelly, M., Lowery, D.B., Ludäscher, B., Macklin, J.A., and Morris, P.J., 2013, Semantic annotation of mutable data: PLoS ONE, v. 8, no. 11, e76093, http://dx.doi.org/10.1371/journal.pone.0076093.

O’Brien, C.W., 1995, Curculionidae, premiere biocontrol agents (Coleoptera: Curculionidae): Memoirs of the Entomological Society of Washington, v. 14, p. 119-128.

O’Brien, C.W., and Wibmer, G.J., 1982, Annotated checklist of the weevils (Curculionidae sensu lato) of North America, Central America, and the West Indies (Coleoptera: Curculionoidea): Memoirs of the American Entomological Institute, v. 34, p. 1-382, accessed October 25, 2015, at http://academic.uprm.edu/ franz/WeevilCourseResources/ OBrienWibmer1982-WeevilsNCAWI.pdf.

Oberprieler, R.G., Marvaldi, A.E., and Anderson, R.S., 2007, Weevils, weevils, weevils everywhere: Zootaxa, v. 1668, no. 491-520, accessed October 25, 2015, at http://www. mapress.com/zootaxa/2007f/z01668p520f.pdf.

Rabaglia, R.J., 2002, XVII-Scolytinae Latreille 1807, in Arnett, R.H., Jr., Thomas, M.C., Skelley, P.E., and Frank, J.H., eds., American beetles - Polyphaga - Scarabaeoidea to Curculionoidea, v. 2: Boca Raton, Florida, CRC Press, p. 792-805.

Ramírez, M.J., Coddington, J.A., Maddison, W.P., Midford, P.E., Prendini, L., Miller, J., Griswold, C.E., Hormiga, G., Sierwald, P., Scharff, N., Benjamin, S.P., and Wheeler, W.C., 2007, Linking of digital images to phylogenetic data matrices using a morphological ontology: Systematic Biology, v. 56, no. 2, p. 283-294, http://dx.doi. org/10.1080/10635150701313848.

Rios, N.E., and Bart, H.L., 2010, GEOLocate (version 3.22) - A platform for georeferencing natural history collections data: Belle Chasse, Louisiana, Tulane University Biodiversity Research Institute, accessed October 25, 2015, at http://www.museum.tulane.edu/geolocate/default.html.

Schoenherr, C.J., 1823, Curculionides [Tabula synoptica familiae Curculionidum]: Isis von Oken, v. 10, p. 1132-1146.

Schoenherr, C.J., 1826, Curculionidum dispositio methodica cum generum characteribus, descriptionibus atque observationibus variis seu Prodromus ad Synonymiae Insectorum, partem IV: Lipsiae, Germany, Apud Fridericum Fleisher, 338 p., accessed October 25, 2015, at http://www.biodiversitylibrary.org/item/37905\#page/9/mode/1up.

Schoenherr, C.J., 1833-1845, Synonymia insectorum-Genera et species curculionidum, cum synonymia hujus familiae-Species novae aut hactenus minus cognitae, descriptionibus a Dom. Leonardo Gyllenhal, C.H. Boheman, et entomologis aliis illustratae, v. 1-7: Paris, Roret, accessed October 25, 2015, at http://www.biodiversitylibrary.org/ item/37662\#page/7/mode/1up.

Scoble, M.J., 2004, Unitary or unified taxonomy?:

Philosophical Transactions of the Royal Society of London, Series B, v. 359, no. 1444, p. 699-710, http://dx.doi. org/10.1098/rstb.2003.1456.
Smith, V., Georgiev, T., Stoev, P., Biserkov, J., Miller, J., Livermore, L., Baker, E., Mietchen, D., Couvreur, T.L.P., Mueller, G., Dikow, T., Helgen, K.M., Frank, J., Agosti, D., Roberts, D., and Penev, L., 2013, Beyond dead treesIntegrating the scientific process in the Biodiversity Data Journal: Biodiversity Data Journal, v. 1, no. e995, http:// dx.doi.org/10.3897/BDJ.1.e995.

Smith, V.S., 2014, E-publishing descriptive taxonomy-The convergence of taxonomic journals and databases, in Watson, M., Lyal, C.H.C., and Pendry, C.A., eds., Descriptive taxonomy - The foundation of biodiversity research: Cambridge, U.K., Cambridge University Press, p. 272-295 http://dx.doi.org/10.1017/CBO9781139028004.027.

Valdecasas, A.G., 2011, An index to evaluate the quality of taxonomic publications: Zootaxa, v. 2925, p. 57-62, accessed October 25, 2015, at http://www.mapress.com/ zootaxa/2011/f/zt02925p062.pdf.

Vollmar, A., Macklin, J.A., and Ford, L.S., 2010, Natural history specimen digitization-Challenges and concerns: Biodiversity Informatics, v. 7, no. 2, p. 93-112, http:// dx.doi.org/10.17161/bi.v7i2.3992.

Wägele, H., Klussmann-Kolb, A., Kuhlmann, M., Haszprunar, G., Lindberg, D., Koch, A., and Wägele, J.W., 2011, The taxonomist - an endangered race-A practical proposal for its survival: Frontiers in Zoology, v. 8, no. 25, http://dx.doi. org/10.1186/1742-9994-8-25.

Wheeler, Q.D., Knapp, S., Stevenson, D.W., Stevenson, J., Blum, S.D., Boom, B.M., Borisy, G.G., Buizer, J.L., De Carvalho, M.R., Cibrian, A., Donoghue, M.J., Doyle, V., Gersoni, E.M., Graham, C.H., Graves, P., Graves, S.J., Guralnick, R.P., Hamilton, A.L., Hanken, J., Law, W., Lipscomb, D.L., Lovejoy, T.E., Miller, H., Miller, J.S., Naeem, S., Novacek, M.J., Page, L.M., Platnick, N.I., Porter-Morgan, H., Raven, P.H., Solis, M.A., Valdecasas, A.G., Van Der Leeuw, S., Vasco, A., Vermeulen, N., Vogel, J., Walls, R.L., Wilson, E.O., and Woolley, J.B., 2012, Mapping the biosphere-Exploring species to understand the origin, organization and sustainability of biodiversity: Systematics and Biodiversity, v. 10, no. 1, p. 1-20, http:// dx.doi.org/10.1080/14772000.2012.665095.

Wieczorek, J., Bloom, D., Guralnick, R., Blum, S., Döring, M., Giovanni, R., Robertson, T., and Vieglais, D., 2012, Darwin Core-An evolving community-developed biodiversity data standard: PLoS ONE, v. 7, no. 1, p. e29715, http://dx.doi.org/10.1371/journal.pone.0029715.

Wilson, E.O., 2003, The encyclopedia of life: Trends in Ecology and Evolution, v. 18, no. 2, p. 77-80, http://dx.doi. org/10.1016/S0169-5347(02)00040-X.

Yoder, M.J., Mikó, I., Seltmann, K.C., Bertone, M.A., and Deans, A.R., 2010, A gross anatomy ontology for Hymenoptera: PLoS ONE, v. 5, no. 12, p. e15991, available online at http://dx.doi.org/10.1371/journal.pone.0015991. 


\title{
Influence of Habitat and Region on Spider Communities Along Two Elevation Gradients in the Southwestern U.S.
}

\author{
By Sandra L. Brantley, ${ }^{1}$ Caitlin A. Chapman, ${ }^{2}$ and Neil S. Cobb ${ }^{2}$
}

\section{Abstract}

There has been little research examining the changes in community composition of ground-dwelling arthropods along elevation gradients, and yet, understanding how species are distributed along elevation gradients is critical for understanding how such communities may respond to climate change. This report is one of few comparative studies of spider communities along elevation gradients in the Southwest U.S. We examined the abundance and community composition of ground-dwelling spiders along elevation gradients in northern Arizona (San Francisco Peaks) and New Mexico (Bandelier National Monument), respectively. Our questions were (1) how are spider species distributed across elevation gradients that span piñon-juniper, ponderosa pine, and mixed-conifer habitats, and are there fundamental changes in community composition, or degree of habitat specialization from low to high elevations; (2) how do these patterns compare between similar habitats in two regions of the Southwest; and (3) what is the importance of habitat structure versus geographic distance in terms of community structure and abundance. Key findings from this study were (1) species composition was distinct among habitats for both elevation gradients, despite no consistent differences in overall abundance and species richness; (2) species displayed a strong affinity for specific habitats, 59 percent of the 79 taxa were found in only one habitat type; (3) there was also a strong degree of regionalization, where 77 percent of the 79 species were only found in northern Arizona or northern New Mexico; and (4) habitat affinity was more important than geographic distance, in that spider communities were more similar among the same habitats in different states than communities in adjacent but different habitats in the same area.

\footnotetext{
${ }^{1}$ Museum of Southwestern Biology, University of New Mexico

${ }^{2}$ Colorado Plateau Biodiversity Center and Department of Biological Sciences, Northern Arizona University
}

\section{Introduction}

Many arthropod groups in the southwestern U.S., including spiders, are still poorly described (Parmenter and others, 1995). Ground-dwelling spiders are dominant predators in the region, typically composing 16-38 percent of grounddwelling arthropod species in some habitats (Crawford, 1989; Ellis and others, 2000, 2001). Although scores of species may occupy a single habitat, many spiders are locally rare, although wolf spiders (Lycosidae) and ground spiders (Gnaphosidae) can be abundant (Bradley, 2013). Spiders are defined as generalist predators (Wise, 1993), but their distributions may reflect more specialized preferences for climate and habitat structure, such as the amount of precipitation, canopy cover, or litter depth (Uetz, 1991). Spider community composition may change dramatically over meters in response to changes in habitat structure, suggesting that they can be extremely sensitive to microhabitat changes (Higgins and others, 2014).

Because the southwestern U.S. is characterized by varied topography and gradients (Brown, 1982), spider communities can vary dramatically over short distances in response to changing habitat types (Chatzaki and others, 2005; Bowden and Buddle, 2010; Higgins and others, 2014). Additionally, directional habitat change over elevation gradients provides a proxy for climate change, replacing space for time and allows us to better understand how climate change impacts may affect species and communities. Since higher elevation habitats are often restricted to isolated areas throughout most of the Colorado Plateau, they are considered "at-risk" habitats under rapid climate change (Rehfeldt and others, 2006, 2009). At a larger geographic scale, higher elevation habitats can be separated by more than 50 kilometers $(\mathrm{km})$, creating an archipelago of fragmented habitats. It is unclear how consistently these changes are reflected between these isolated mountain habitats.

During the past 13,000 years, vegetation zones in the Southwest, including the Colorado Plateau, have moved up in elevation and migrated northward as the climate has warmed (Vankat, 2013). In the process, it is likely that ecosystems ranging from mixed conifer forests to subalpine have become fragmented in a sea of lower elevation ecosystems. Concomitantly, species that are adapted to warmer and drier environments, for example, piñon pine (Pinus edulis), juniper 
(Juniperus sp.), and ponderosa pine (Pinus ponderosa), that have come to define southwestern woodlands, have radiated northward. There has been considerable interest in documenting the biogeography of species and communities associated with isolated mountains in southern Arizona, otherwise referred to as sky islands (Masta, 2000). However, there has been virtually no research examining community patterns on elevation gradients throughout the Colorado Plateau, which also contains complex gradients (Vankat, 2013).

An example of recent work on gradients in the region is Lightfoot and others (2008), which compared orthopterans and spiders along a latitudinal gradient that spanned from the Jornada Long-Term Research Program site in southern New Mexico to Bandelier National Monument in northern New Mexico. One of the most interesting results from that study was that spider assemblages were more similar to adjacent but different vegetation types, than they were to spider assemblages in the same vegetation type in different ecoregions. However, the only tree-dominated vegetation type represented in more than one area was piñon-juniper woodland. It is unclear whether these patterns would be apparent in higher-elevation forests. Because higher elevation forests are more fragmented regionally, we expect that spider communities at higher elevations would show even stronger patterns in regional differences than was reported in Lightfoot and others (2008).

In this paper, we compare spider communities from two elevation gradients that are separated longitudinally from each other, one in the San Francisco Peaks (SFP) in northern Arizona, and the other in the Jemez Mountains (Bandelier National Monument [BAND]) in northern New Mexico. We address the following questions: (1) which species make up the ground-dwelling spider communities and do they show preferences for a given habitat type or do they occur in multiple habitats; (2) how do species composition and habitat preference compare between two widely separated locations with the same designated habitat types; and (3) from this comparison can we show the strength of habitat type versus ecoregion (in other words, adjacent but different vegetation types) in structuring these communities?

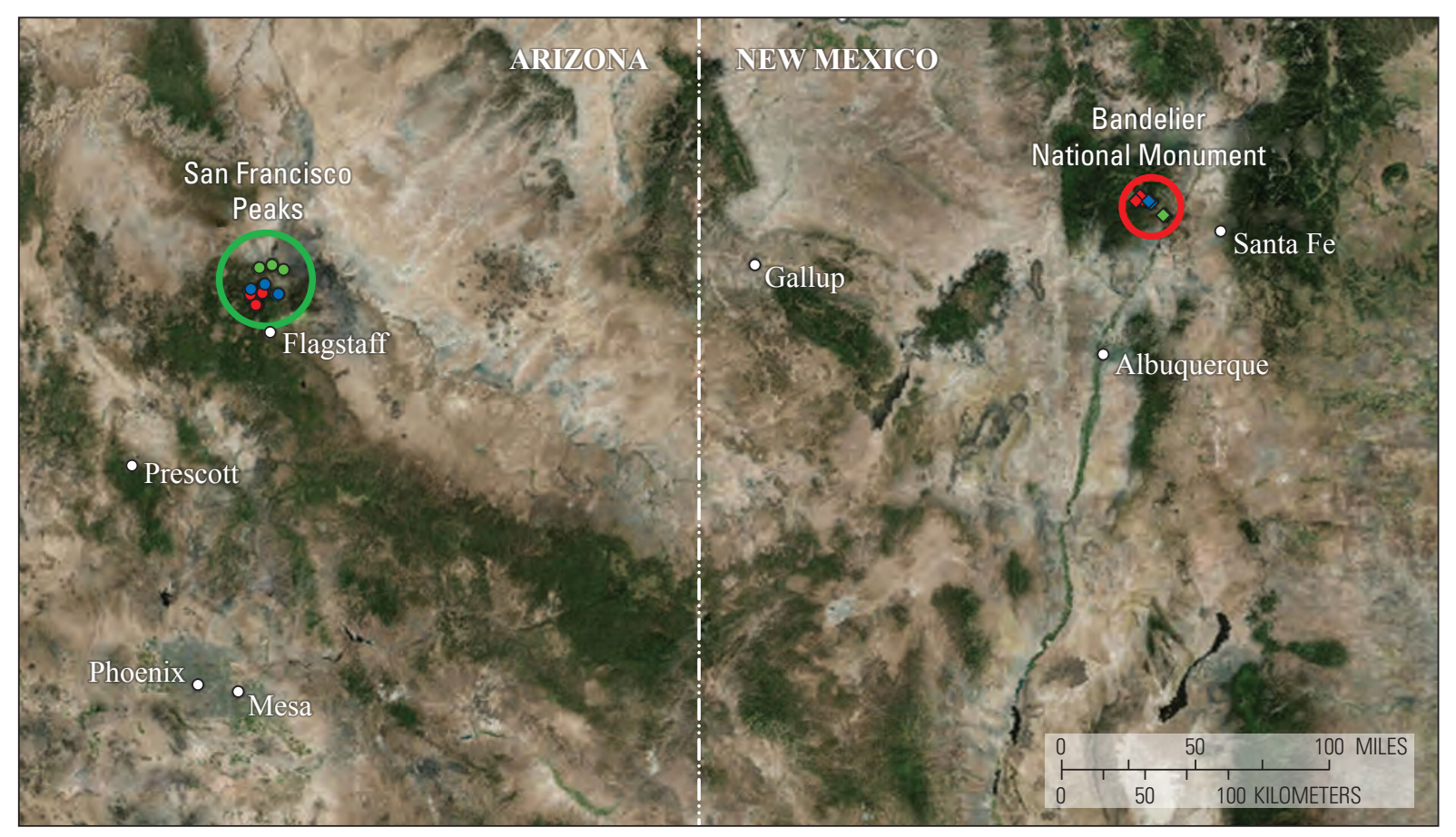

\section{EXPLANATION}

$\begin{array}{ll}\text { San Francisco Peaks habitats } & \text { Bandelier National Monument } \\ \text { o Piñon-juniper } & \square \text { Piñon-juniper } \\ \text { O Ponderosa pine } & \square \text { Ponderosa pine } \\ \text { o Mixed conifer } & \square \text { Mixed conifer }\end{array}$

Figure 1. Map of the southern Colorado Plateau including the San Francisco Peaks (circles) and Bandelier National Monument (squares) study areas. Darker green areas between the two study areas typically represent ponderosa pine forests and mixed conifer vegetation types, as well as higher elevation forests. Piñon-juniper woodlands are nearly continuous between the two areas, whereas higher elevation forests are more fragmented. 
Table 1. Habitat and climate characteristics at the two study locations, San Francisco Peaks (SFP), AZ and Bandelier National Monument (BAND), NM. Mean annual precipitation, maximum temperature, and minimum temperature are based on modeled $800 \mathrm{~m}$ PRISM data, which are not specific enough for each line of traps.

$\left[{ }^{\circ} \mathrm{C}\right.$, degrees Celsius; $\mathrm{m}$, meters; $\mathrm{cm}$, centimeters $]$

\begin{tabular}{|c|c|c|c|c|c|c|c|c|}
\hline \multirow[t]{2}{*}{ Area } & \multirow{2}{*}{$\begin{array}{l}\text { Elevation } \\
\qquad(\mathrm{m})\end{array}$} & \multirow{2}{*}{ Latitude } & \multirow[t]{2}{*}{ Longitude } & \multirow[t]{2}{*}{ Habitat } & \multirow[t]{2}{*}{ Dominant trees } & \multirow{2}{*}{$\begin{array}{l}\text { Annual } \\
\text { precipitation } \\
\text { (cm) }\end{array}$} & \multicolumn{2}{|c|}{$\begin{array}{l}\text { Annual temperature, } \\
\left({ }^{\circ} \mathrm{C}\right) \\
\end{array}$} \\
\hline & & & & & & & Maximum & Minimum \\
\hline BAND & 1,948 & 35.7618 & -106.2654 & $\begin{array}{l}\text { Piñon- } \\
\text { juniper }\end{array}$ & Pinus edulis, Juniperus monosperma & 39.6 & 18.1 & 0.9 \\
\hline SFP & 2,285 & 35.3726 & -111.5875 & $\begin{array}{l}\text { Ponderosa } \\
\text { pine }\end{array}$ & Pinus ponderosa & 52.7 & 15.5 & 0.6 \\
\hline BAND & 2,712 & 35.8511 & -106.4102 & $\begin{array}{l}\text { Mixed- } \\
\text { conifer }\end{array}$ & $\begin{array}{l}\text { Pinus strobiformis, Pseudotsuga menziesii, Abies } \\
\text { concolor, Populus tremuloides }\end{array}$ & 71.5 & 13.6 & -0.4 \\
\hline
\end{tabular}

\section{Sites and Methods}

The San Francisco Peaks are located in Coconino County, Arizona; Bandelier National Monument is located in Sandoval County, New Mexico (fig. 1). Both areas are of volcanic origin with volcanic activity beginning about $6 \mathrm{Ma}$ for SFP (Priest and others, 2001) and $18 \mathrm{Ma}$ for BAND (Goff, 2009).

In both studies we compared three vegetation types, piñon-juniper woodland ( $\mathrm{PJ}$; low elevation), ponderosa pine (PIPO; medium elevation), and mixed-conifer/aspen forest (MC; higher elevation). The areas are at a similar latitude and approximately $475 \mathrm{~km}$ apart. SFP is part of the Arizona mountains forests ecoregion, BAND is part of the Southern Rockies forests ecoregion, and both are part of the broader temperate coniferous forest major habitat type (Ricketts and others, 1999). The data used for these comparisons were collected in 2009-11. We restricted the analysis to the three vegetation types where we had comparable data from each of the two gradients. The BAND study has been ongoing for more than 20 years (1992-present), sampling continuously during the growing season for many ground-dwelling arthropod taxa from piñon-juniper woodlands through mixed conifer (Lightfoot and others, 2008). The SFP study was initiated in 2010 and focused on ants, beetles, and spiders.

The three habitats studied at SFP and BAND are comparable with regard to elevation, dominant tree species, and climate (table 1). Temperature and precipitation data are based on modeled 30-year mean data using an 800-m pixel size (PRISM Climate Group, 2014), and are similar between sites. We established meteorological stations for all three habitats in the SFP since 2002 (Merriam-Powell Center for Environmental Research, 2014). The meteorological data do vary $2-8$ centimeters $(\mathrm{cm})$ in precipitation and $3-5^{\circ} \mathrm{C}$ in temperature from PRISM data, indicating that modeled PRISM values do not precisely reflect climate at our scale of interest. We do not have comparable meteorological station data available for all of the BAND habitats.
To sample ground-dwelling spiders we used pitfall traps, which differed in trap type and sample duration between BAND and SFP studies. The SFP pitfalls consisted of $32 \times 200$ millimeters $(\mathrm{mm})$ lipped borosilicate test tubes inserted in polyvinyl chloride (PVC) sleeves with a PVC cover, and filled with diluted ethylene glycol (Higgins and others, 2014). Pitfalls were placed in 2 lines of 10 traps in $\mathrm{PJ}$; the lines in PIPO and MC were arranged with one set in the open and one set in forested areas to sample these two very distinct microhabitats that do not occur in the more open woodlands. Traps within a line and between lines were 10 meters (m) apart. We had 20 total traps per site for PJ, and 40 traps per site for PIPO and MC. Sampling occurred at three sites for each of the three vegetation types. Samples were collected after one month (approximately late August to late September) in 2010 and 2011.

The pitfall traps at BAND were somewhat larger (plastic cups inside tin cans, $7.5 \mathrm{~cm}$ top diameter and $10 \mathrm{~cm}$ deep) and placed in 5 lines of 6 traps, for a total of 30 traps per site. Within a line, traps were $10 \mathrm{~m}$ apart; the lines were at least $100 \mathrm{~m}$ apart. Propylene glycol was used as the preservative. Although we did not directly compare trap types, the smaller pitfall traps used for the SFP study were probably more efficient at collecting smaller individuals as reflected by the relatively high number of immature spiders. We also suggest they were more effective in sampling a larger number of species, as most of the species found in the SFP study and not found at BAND during the same time period have been recorded at BAND in other years. The open areas and closed canopy areas of PIPO sites at SFP were sampled separately and then combined. At BAND, the PIPO site was sampled continuously through open and closed canopy areas without separating them. More detail about the sampling can be found in Lightfoot and others (2008).

Samples were collected after two months (approximately late July to late September) in 2010 and 2011. In summer 2011, the Las Conchas wildfire burned most of the trap areas at BAND in the PIPO and MC habitats; therefore we used 
pre-fire data from the fall of 2009 and 2010 for comparison. In order to compare results from both studies, we standardized the metric for spider catches that reflected the number of spiders captured per $10-\mathrm{cm}$ pitfall trap perimeter per 30 days. Specimens from both studies were collected into 70 percent ethanol, sorted, and identified at the University of New Mexico (UNM) or Northern Arizona University (NAU). For both studies, the primary reference collection was deposited at UNM Museum of Southwestern Biology and a second reference at the NAU Colorado Plateau Museum of Arthropod Biodiversity.

\section{Data Analysis}

To address our first and second research questions, we focused on five metrics that describe the spider communities at both locations and in the three habitats: (1) species richness and total abundance, (2) species composition, (3) familylevel patterns, (4) dominant species, and (5) indicator species. These metrics then allowed us to address our third question
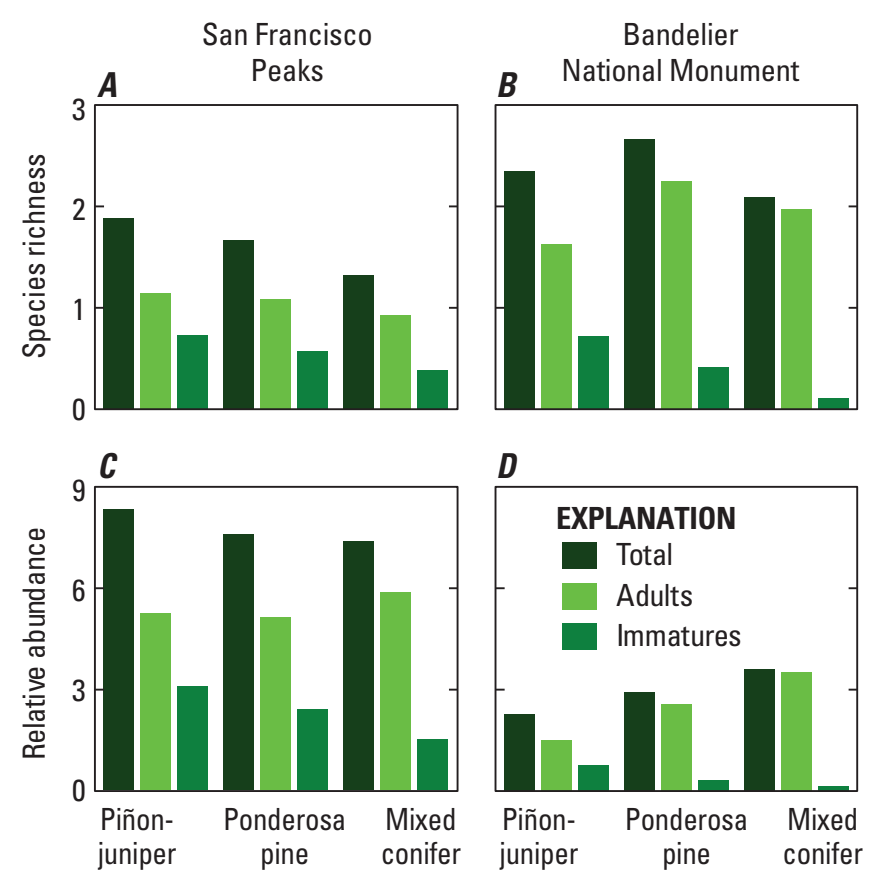

Figure 2. Graph of species richness $(A, B)$ and relative abundance $(C, D)$ in three habitat types: piñon-juniper, ponderosa pine, and mixed-conifer at the San Francisco Peaks (SFP) and Bandelier National Monument (BAND) study sites. Species richness in mean number of species per standardized trap/day of ground-dwelling spider species and relative abundance per standardized trap/day. Standardized trap size explained in Methods section. Significance values between SFP and BAND given in Results section. concerning the strength of habitat type or ecoregion on structuring the communities.

We combined data from the open and closed canopy SFP sites in PIPO and MC to more closely match the sampling at BAND. We defined spider species as generalists if they occurred in more than one habitat type and as specialists if they occurred in one habitat only. Single representatives of a given species were removed from all analyses. We analyzed the data two ways: (1) with immature spiders included in the analysis because they make up a large part of the active life stages and biomass (Norris, 1999; Jimenez-Valverde and Lobo, 2006), and (2) with adult stages only. To minimize the differences in sampling technique (trap design and placement) between SFP and BAND, we standardized the spider abundance values to reflect number of individuals per $10-\mathrm{cm}$ length of the pitfall circumference per day of sampling.

For both locations, we compared spider species composition, species richness, and relative abundance in the habitats. To analyze differences in species richness and abundance between SFP and BAND, we used a two-factor analysis of variance (ANOVA): the factors were location (SFP and BAND) and habitat type (PJ, PIPO, and MC) nested within each location. We used species composition and the relative abundance of adults to analyze habitat and location effects (IBM Corp., 2013) for mean trap numbers, and Primer-6 software for multidimensional scaling (MDS) and an unweighted Bray-Curtis cluster analysis (Clarke and Gorley, 2006). Because samples were collected multiple times from the same traps, we used the PERMANOVA software (Anderson and others, 2008a) to analyze differences between locations and habitats. Data were square root transformed before analysis. Indicator species analysis was performed using PC-ORD software (McCune and others, 2002). The analysis is based on (1) the relative frequency of species and (2) the concentration of their abundance within groups, called fidelity and exclusivity, respectively, by McCune and others (2002). Species that are consistently found in only one habitat, even if they are rare, are strong indicators for that habitat.

\section{Results}

\section{Species Richness and Abundance}

A total of 1,741 individuals were collected in 79 taxa identified at the genus or species level (appendix). For all habitats at both SFP and BAND, Lycosidae and Gnaphosidae were the dominant families, as is common for grounddwelling spiders throughout North America (Bradley, 2013). For both SFP and BAND, total species richness decreased with increasing elevation between PJ (38 species) and PIPO (24 species) habitats but increased again in MC ( 30 species), with no mid-elevation increase in richness, as seen in some other groups (Rahbeck, 1995). Examining species richness on 
A All spiders
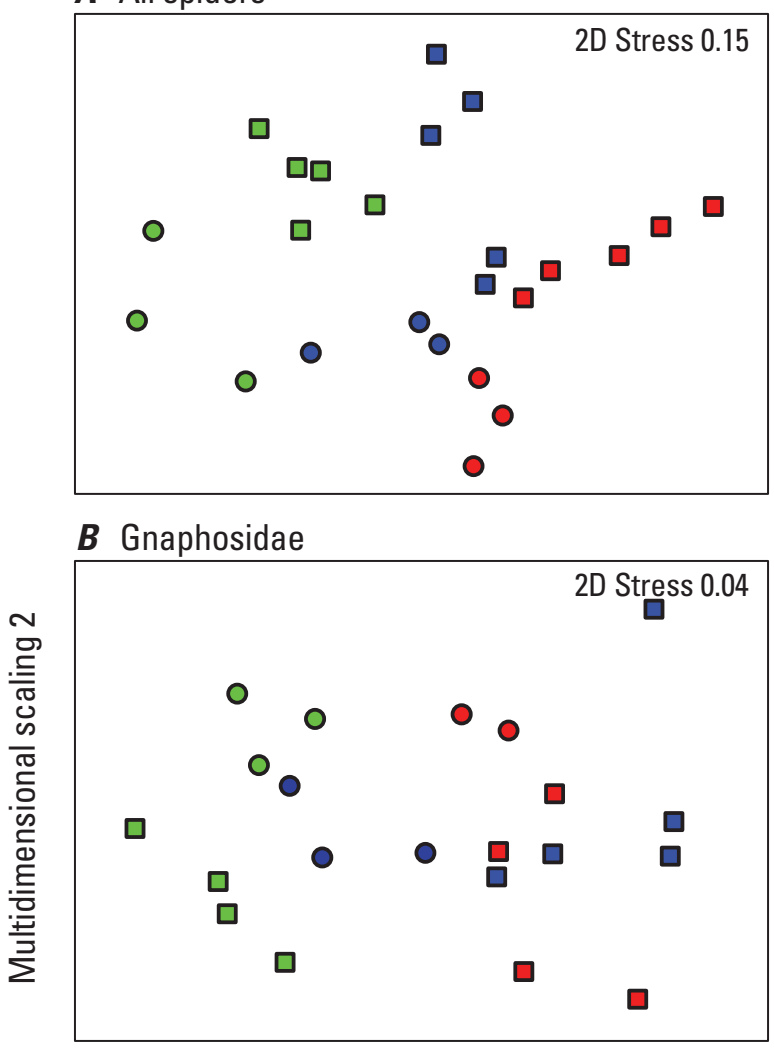

C Lycosidae

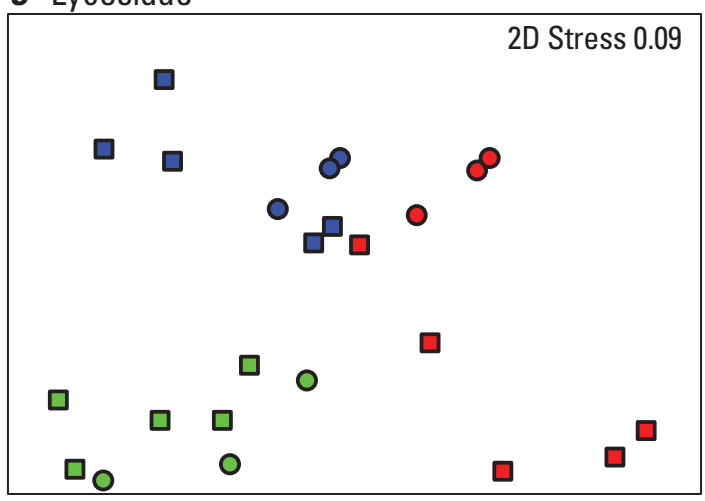

Multidimensional scaling 1

\section{EXPLANATION}

$\begin{array}{ll}\text { San Francisco Peaks } & \text { Bandelier National Monument } \\ \text { O Piñon-juniper } & \square \text { Piñon-juniper } \\ \text { O Ponderosa pine } & \square \text { Ponderosa pine } \\ \text { O Mixed conifer } & \square \text { Mixed conifer }\end{array}$

Figure 3. Multidimensional scaling ordination of grounddwelling spider species (immature spider population removed). $A$, All spider taxa; $B$, Gnaphosid species only; $C$, Lycosid species only. Each symbol represents a line of traps. San Francisco Peaks site, circles; Bandelier National Monument site, squares; piñon-juniper habitat, green; ponderosa pine habitat, blue; mixedconifer habitat, red.
Table 2. Number of species occurring in single and multiple habitats at San Francisco Peaks (SFP) and Bandelier National Monument (BAND) sites. Piñon-juniper habitat, PJ; ponderosa pine habitat, PIPO; and mixed-conifer habitat, MC.

\begin{tabular}{lcccc}
\hline \multicolumn{1}{c}{ Habitat } & SFP only & BAND only & $\begin{array}{c}\text { SFP and } \\
\text { BAND }\end{array}$ & Total \\
\hline PJ & 14 & 6 & 0 & 20 \\
PIPO & 5 & 5 & 0 & 10 \\
MC & 8 & 7 & 2 & 17 \\
PJ and PIPO & 7 & 5 & 7 & 19 \\
PIPO and MC & 0 & 2 & 4 & 6 \\
PJ, PIPO, and MC & 1 & 1 & 5 & 7 \\
Totals & $\mathbf{3 5}$ & $\mathbf{2 6}$ & $\mathbf{1 8}$ & $\mathbf{7 9}$ \\
\hline
\end{tabular}

a per sample basis indicated overall differences among habitats $(\mathrm{df}=2, \mathrm{~F}=4.789, \mathrm{P}=0.009)$ with a weak trend in decreasing species richness with increasing elevation at SFP and no significant differences at BAND (fig. 2). As was the case for most of the analyses, taxa dominated by adults (rather than immature individuals) showed differences within and between study areas. There were no differences in abundance among habitats $(\mathrm{df}=2, \mathrm{~F}=0.068, \mathrm{P}=0.934)$. Differences for location * habitat were not significant for richness $(\mathrm{df}=2, \mathrm{~F}=1.469$, $\mathrm{P}=0.231)$ nor for abundance $(\mathrm{df}=2, \mathrm{~F}=1.280, \mathrm{P}=0.279)$. Species richness was significantly greater at BAND $(\mathrm{df}=1$, $\mathrm{F}=31.698, \mathrm{P}<0.001$ ), but significantly more individuals were collected at SFP (df=1, F=75.821, $\mathrm{P}<0.001)$ (fig. 2). More species that occurred at BAND also occurred at SFP, while more unique species were collected at SFP (table 2, appendix).

\section{Spider Communities Among Habitats and Locations}

We found strong differences in the composition of spider communities among habitats and less so between locations; this clarified the ANOVA results, which looked only at number of species (richness) and abundance (table 2, appendix). In agreement with these values, the results of PERMANOVA tests showed the effect of location (SFP versus BAND) was not significant for all spiders combined (pseudo-F $=1.9918$, $\mathrm{P}=0.231$ ), for gnaphosids (pseudo- $\mathrm{F}=1.4559, \mathrm{P}=0.299$ ), or for lycosids ( $\mathrm{pseudo}-\mathrm{F}=1.8578, \mathrm{P}=0.322$ ). However, the effect of habitat was significant for all spiders combined (pseudo- $\mathrm{F}=5.9398, \mathrm{P}=0.001$ ), for gnaphosids (pseudo- $\mathrm{F}=3.7594$, $\mathrm{P}=0.001$ ) and for lycosids (pseudo- $\mathrm{F}=10.697, \mathrm{P}=0.001$ ).

We used multidimensional scaling ordination (without including the immature stages) to visualize differences (fig. 3A-C) among habitats and locations. Spiders in the SFP habitats showed less scatter than BAND; PJ habitat was well separated from the other two habitats. Some of the trap lines in PIPO and $\mathrm{MC}$ sites overlapped at both locations. The Gnaphosidae showed less separation by habitat or location (fig. $3 B$ ) than the 
Lycosidae, which were important contributors to the separation of habitats (fig. 3C). Analysis at the family level indicated that lycosids, gnaphosids, and linyphiids showed significant trends in abundance as elevation increased; lycosids $(\mathrm{df}=2, \mathrm{~F}=10.786$, $\mathrm{P}<0.001)$ and linyphiids $(\mathrm{df}=2, \mathrm{~F}=8.305, \mathrm{P}<0.001)$ increased, and gnaphosids $(\mathrm{df}=2, \mathrm{~F}=20.380, \mathrm{P}<0.001)$ decreased.

The cluster analysis (fig. 4) provided more resolution for the patterns seen in the MDS (fig. 3). The main division in the dendrogram is between PJ sites and combined PIPO and MC sites, with about a 20 percent similarity. Later divisions separated along location and habitat, with some mixing of both. The similarity levels among these sites never exceeded 70 percent, showing that there was a large amount of variation in both habitat and location.

The five most abundant species at each location and habitat type showed little overlap among locations (table $3 A-C$ ). The top five species made up about 50 percent of the abundance in PJ at SFP and BAND, but for the other two habitats, the proportion increased, as expected with fewer species at higher elevations (with the exception of SFP PIPO), but the proportion increased more at BAND (61.6 percent at PIPO and 82.6 percent at MC) than at SFP (48.4 percent and 76.6 percent at MC). The numbers of immature stages were high enough in most habitats to make up a large proportion of total spider numbers. Families contributing the most immature stages were Gnaphosidae and Lycosidae.

\section{Indicator Species Analysis}

Another way of looking at habitat specificity is through indicator species analysis (table 4), which detects more than just numerically dominant species occurring in a habitat, as described in the Data Analysis section. For SFP, two of the five dominant PJ species were also indicators; at PIPO one of the dominant five was an indicator; and at $\mathrm{MC}$ two of the five were indicators. For BAND, one of the dominant five species was an indicator, and two of the five were indicators in PIPO and MC. Species that were not numerically abundant but important in distinguishing habitat types were Pardosa montgomeryi at SFP and Anyphaena hespar, Trochosa terricola, Varacosa gosiuta, and Zorocrates karli at BAND. Lycosids were indicators in all habitats (fig. 3C). Gnaphosids were indicators in PJ and MC, although present in all habitats, often as immature stages of Zelotes.

In general, spider species were specialists in habitat preference, with 20 in PJ only, 10 in PIPO only, and 17 in MC only or 59 percent of the total (table 2). Nineteen occurred in PJ and PIPO, 6 in PIPO and MC, and 7 in all three habitats (including immature stages of Callilepis, which probably represent multiple species, and the genus Cicurina, whose taxonomy is unsettled at present but at our locations probably includes several species). Within location, the number of species occurring in only one habitat at SFP was 14 in PJ, 5 in

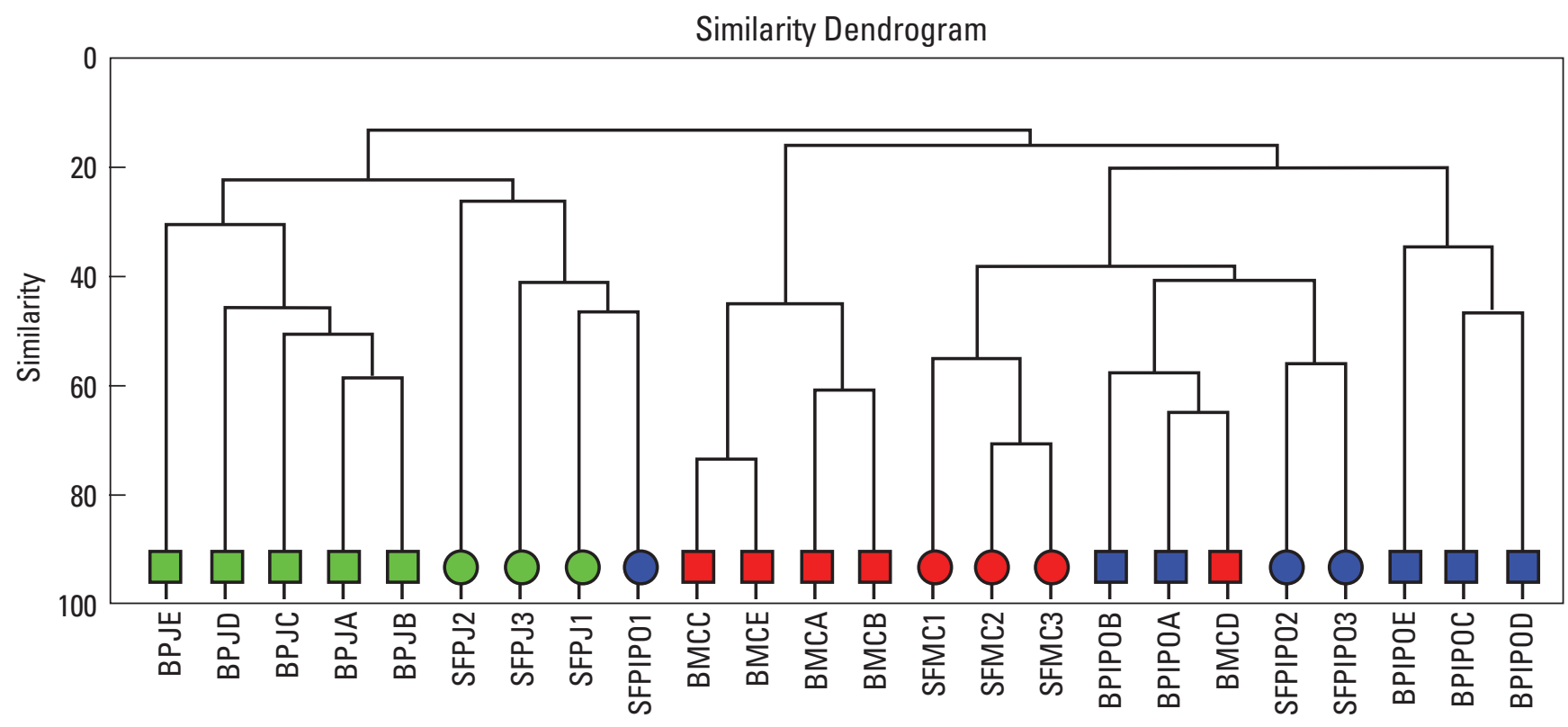

EXPLANATION

Figure 4. Dendrogram from Bray-Curtis cluster analysis for the effect of habitat and location on spider communities.
San Francisco Peaks sites

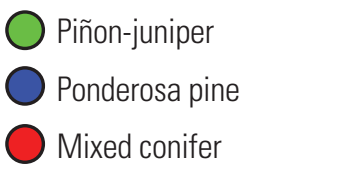

Bandelier National Monument sites

Piñon-juniper

Ponderosa pine

Mixed conifer 
Table 3. The top five taxa, in relative abundance, in each habitat type. A, piñon-juniper; $B$, ponderosa pine, and $\mathrm{C}$, mixed-conifer.

[imm, immature individuals]

\begin{tabular}{|c|c|c|c|c|c|}
\hline \multicolumn{6}{|c|}{ A) Piñon-juniper } \\
\hline \multicolumn{3}{|c|}{ San Francisco Peaks } & \multicolumn{3}{|c|}{ Bandelier National Monument } \\
\hline Taxon & $\begin{array}{c}\text { Percent } \\
\text { of total } \\
\text { abundance }\end{array}$ & $\begin{array}{l}\text { Cumulative } \\
\text { percent }\end{array}$ & Taxon & $\begin{array}{c}\text { Percent } \\
\text { of total } \\
\text { abundance }\end{array}$ & $\begin{array}{c}\text { Cumulative } \\
\text { percent }\end{array}$ \\
\hline Zelotes anglo & 19.1 & 19.1 & Schizocosa mccooki & 14.4 & 14.4 \\
\hline Drassyllus mexicanus & 9.9 & 29.0 & Drassodes gosiutus & 13.3 & 27.7 \\
\hline Zelotes imm. & 8.9 & 37.9 & Zelotes imm. & 9.9 & 37.6 \\
\hline Drassodes imm. & 5.7 & 43.6 & Cicurina spp. & 7.7 & 45.3 \\
\hline Habronattus imm. & 5.7 & 49.3 & Alopecosa kochi & 6.1 & 51.4 \\
\hline \multicolumn{6}{|c|}{ B) Ponderosa pine } \\
\hline \multicolumn{3}{|c|}{ San Francisco Peaks } & \multicolumn{3}{|c|}{ Bandelier National Monument } \\
\hline Taxon & $\begin{array}{c}\text { Percent } \\
\text { of total } \\
\text { abundance }\end{array}$ & $\begin{array}{l}\text { Cumulative } \\
\text { percent }\end{array}$ & Taxon & $\begin{array}{c}\text { Percent } \\
\text { of total } \\
\text { abundance }\end{array}$ & $\begin{array}{c}\text { Cumulative } \\
\text { percent }\end{array}$ \\
\hline Alopecosa kochi & 16.7 & 16.7 & Pardosa yavapa & 17.1 & 17.1 \\
\hline Pardosa yavapa & 9.2 & 25.9 & Alopecosa kochi & 13.7 & 30.8 \\
\hline Zelotes imm. & 8.1 & 34.0 & Varacosa gosiuta & 11.8 & 42.6 \\
\hline Xysticus montanensis & 7.7 & 41.7 & Cicurina spp. & 11.4 & 54.0 \\
\hline Pardosa imm. & 6.7 & 48.4 & Zelotes imm. & 7.6 & 61.6 \\
\hline \multicolumn{6}{|c|}{ C) Mixed-conifer } \\
\hline \multicolumn{3}{|c|}{ San Francisco Peaks } & \multicolumn{3}{|c|}{ Bandelier National Monument } \\
\hline Taxon & $\begin{array}{c}\text { Percent } \\
\text { of total } \\
\text { abundance }\end{array}$ & $\begin{array}{c}\text { Cumulative } \\
\text { percent }\end{array}$ & Taxon & $\begin{array}{c}\text { Percent } \\
\text { of total } \\
\text { abundance }\end{array}$ & $\begin{array}{c}\text { Cumulative } \\
\text { percent }\end{array}$ \\
\hline Alopecosa kochi & 55.6 & 55.6 & Cicurina spp. & 50.5 & 50.5 \\
\hline Pardosa imm. & 7.0 & 62.6 & Pardosa uncata & 11.1 & 61.6 \\
\hline Zelotes fratris & 6.2 & 68.8 & Helophora orinoma & 9.2 & 70.8 \\
\hline Zelotes imm. & 4.1 & 72.9 & Alopecosa kochi & 8.6 & 79.4 \\
\hline Micaria pulicaria & 3.7 & 76.6 & Zelotes fratris & 3.2 & 82.6 \\
\hline
\end{tabular}

PIPO, and 8 in MC, for a total of 27 out of 35 (77 percent); at BAND there were 6 in PJ, 5 in PIPO, and 7 in MC, for a total of 18 out of 26 species (69 percent).

\section{Discussion}

A major pattern that emerged was a significant degree of partitioning of communities among habitats in a predictable transition from piñon-juniper woodlands to ponderosa forests and mixed-conifer forests. We also found differences in spider communities among the regions, but not nearly to the degree as reported by Lightfoot and others (2008) who found that adjacent but different habitats were much more similar than the same habitats in two areas. MDS (fig. 3) clearly showed that both habitat and location influenced the spider communities; but cluster analysis (fig. 4) and PERMANOVA results showed that habitat was the stronger of the two. Our study differed in that both areas are located on the southern Colorado Plateau and there has been continuity of habitats between SFP and BAND in the last 20,000 years, although higher elevation habitats have become more fragmented in the last 10,000 years (Vankat, 2013). Both the SFP and BAND also share the same forested vegetation types, whereas the three areas studied in Lightfoot and others (2008) ranged along a latitudinal gradient from the southern Chihuahuan desert (Jornada) to the northernmost Chihuahuan desert (Sevilleta National Wildlife 
Table 4. Indicator species by habitat for San Francisco Peaks (SFP) and Bandelier National Monument (BAND) sites. PJ, piñon-juniper habitat; PIPO, ponderosa pine habitat; and MC, mixed-conifer habitat; NC, species not collected, therefore could not contribute to indicator value for combined locations; NP, not performed since species did not occur at SFP and BAND; NS, species not statistically significant as an indicator; imm., immature individuals.

\begin{tabular}{|c|c|c|c|c|}
\hline \multirow{2}{*}{ Habitat } & \multirow{2}{*}{ Species } & \multicolumn{3}{|c|}{ P-value } \\
\hline & & SFP \& BAND & SFP & BAND \\
\hline \multirow[t]{9}{*}{ PJ } & Schizocosa mccooki & 0.0002 & 0.0342 & 0.0012 \\
\hline & Habronattus imm. & 0.0004 & NS & 0.0134 \\
\hline & Latrodectus hesperus & 0.0036 & NS & 0.011 \\
\hline & Drassyllus mexicanus & 0.0066 & NS & NS \\
\hline & Drassodes imm. & NP & 0.0342 & $\mathrm{NC}$ \\
\hline & Zorocrates karli & NP & $\mathrm{NC}$ & 0.011 \\
\hline & Zelotes anglo & NP & 0.0342 & $\mathrm{NC}$ \\
\hline & Schizocosa imm. & NP & $\mathrm{NC}$ & 0.0134 \\
\hline & Drassodes gosiutus & NS & NS & 0.0134 \\
\hline \multirow[t]{6}{*}{ PIPO } & Pardosa yavapa & 0.0002 & 0.0372 & 0.0034 \\
\hline & Phrurolithus camawhitae & 0.0092 & NS & 0.023 \\
\hline & Varacosa gosiuta & NP & $\mathrm{NC}$ & 0.0106 \\
\hline & Hololena hola & 0.0352 & NS & 0.0346 \\
\hline & Xysticus imm. & 0.049 & NS & NS \\
\hline & Anyphaena hespar & NP & $\mathrm{NC}$ & 0.0372 \\
\hline \multirow[t]{6}{*}{$\mathrm{MC}$} & Pardosa uncata & 0.0006 & NS & 0.0016 \\
\hline & Cicurina spp. & 0.0038 & NS & 0.0016 \\
\hline & Trochosa terricola & $\mathrm{NP}$ & $\mathrm{NC}$ & 0.0116 \\
\hline & Zelotes fratris & 0.0492 & NS & NS \\
\hline & Alopecosa kochi & NS & 0.0084 & NS \\
\hline & Pardosa montgomeryi & NP & 0.0322 & $\mathrm{NC}$ \\
\hline
\end{tabular}

Refuge) and finally to the southern Colorado Plateau (BAND). This suggests that there has been a much longer period of separation or fragmentation of habitats among the three areas.

A possible methodological reason explaining the different results between our study and that of Lightfoot and others (2008) may be the length of sampling time: two years and only the fall season for our study and seven years of year-round sampling for Lightfoot and others (2008). It is possible that short-term sampling collects mainly the more widespread or dominant species within habitats while longer-term sampling picks up more rare species (which might include more geographically restricted species), leading to a pattern of greater regional influence on species composition. A way to test this idea with the data from Lightfoot and others (2008) is to analyze the data for a few years only, and then add subsequent years to see if the pattern changes or not, and if so, determine how many years of sampling are needed before a change is detected. Even with our smaller dataset there were indications that location influenced spider richness and abundance, but probably not as strongly as habitat type (fig. $3 A-C$ ). There were more unique species at SFP (35) than BAND (28) (appendix), which was driving some of the location difference. This may be due to regional distribution differences of species, such as Calilena spp., which occur westward from Arizona, Utah, and Nevada, but some of the species are widespread in the western U.S. (A. utahana, M. pulicaria, and Z. lasalana, so at least a part of the difference was likely due to undersampling. The three species just mentioned occurred at BAND, but not during the years used in this study (S. Brantley, unpub. data, 2015). Long-term studies may help us differentiate how habitat type and region organize spider communities.

We found the common pattern of decreasing species number with increasing elevation to be more pronounced at SFP (33 species in PJ, 28 in PIPO, and 18 in MC) with no mid-elevation increase, while at BAND richness changed little over the 3 habitats (22 species in PJ, 24 in PIPO, and 20 in MC), with only a slight mid-elevation increase (appendix). In mountain ranges in Canada, Bowden and Buddle (2010) did not show consistent changes in spider species numbers with elevation, in part because habitat structure did not always change (for example, forested sites occurred at different elevations). From this, we expected that species occurring in two of our habitats would be more likely to occur in PIPO and MC, because of similar canopy cover and litter. Instead, our results showed that species occurring in two habitats were more likely to be in PJ and PIPO at SFP, and at BAND were as likely to be in PJ and PIPO as PIPO and $\mathrm{MC}$. Elevation changes cover a mixture of abiotic and biotic factors, which can confound explanation of species patterns (Körner, 2007); Bowden and Buddle's (2010) study design was able to separate abiotic elevation factors from vegetation and other habitat factors on their species distribution. In our study, we may be seeing the increasing importance of abiotic features at high-elevation besides forest cover (table 1 and Methods section), such as lower temperatures and higher precipitation (Rahbeck, 1995). Gnaphosids on Crete (Chatzaki and others, 2005) included many species that were widely tolerant of elevation changes. The gnaphosids at SFP and BAND were also somewhat less restricted by elevation (fig. $3 B$ ), showing less distinction between habitats compared with the lycosids (fig. 3C).

Otto and Svensson (1982) found different patterns in spider occurrence on an elevation gradient in Norway. At their sites, spiders at the highest elevation were widely distributed and occurred at some lower elevations, while the lowest elevation species were more restricted. An explanation they proposed is that high-elevation species disperse widely (referred to as fugitive species) and therefore occupy large areas. Spider species found in this high-latitude location may have already overcome the harsh abiotic conditions (compared to the southwestern US), where our mixed-conifer species were restricted perhaps by relatively hot and dry conditions at lower elevations and by less area where cooler conditions occur. The Linyphiidae at our sites were generally restricted to mixed-conifer habitat (appendix). 
Although spiders are typically described as generalists in prey choice (Wise, 1993), they are often more specialized in their habitat preferences (Uetz, 1991). Of the 79 species collected over 3 habitats and 2 locations in this study, 59 percent were found in 1 habitat only (table 2, appendix). Within the dominant families Lycosidae and Gnaphosidae, which are speciose, there were examples of both habitat specialists and generalists. In the Lycosidae, specialists included $P$. montgomeryi, $P$. uncata, and $T$. terricola in MC only, $P$. orophila, P. yavapa, and S. mccooki in PJ and PIPO; an example of a generalist is $A$. kochi, found in all habitats at both locations. In the Gnaphosidae, lower-elevation species included those in the genera Drassodes, Herpyllus, and Micaria, while MC genera included Gnaphosa and Haplodrassus. In the large gnaphosid genus Zelotes, Z. anglo, and Z. lasalanus occurred in PJ and PIPO, while $Z$. fratris occurred in PIPO and MC. Mallis and Hurd (2005), working on spider communities in six successional habitats in Virginia, found 50 percent were specialists (occurring in only one habitat) and no species was found in more than four habitats. Pardosa species were important there, and the widespread $T$. terricola also occurred in two habitats (the authors' disturbance recovery site and old field), whereas in our study it occurred only in mixed-conifer. Chatzaki and others (2005) sampled gnaphosids in five habitats on elevation gradients on Crete, finding that 14 (26 percent) of 54 species were found in only one habitat, and that the highest elevation sites had the fewest species and very little overlap with species from the other four habitats.

All habitats were strongly dominated by $4-6$ species. The five most abundant taxa in each habitat were often different between locations (table $3 A-C$ ); when the habitats shared species, they were in different rank order. In contrast Roughley and others (2006) found four out of five of the most abundant spider species were shared between tallgrass prairie and forest in an ecotone setting in Manitoba, Canada. In fact, the dominant spider, Pardosa moesta, occurred in both habitats. While these habitats appear very different to people, they may provide some common features, such as cover and soil moisture, which are likely important from the spiders' point of view. In a Colorado grassland and mixed-grass/shrub landscape, Weeks and Holtzer (2000) found virtually no species overlap among species of Lycosidae or Gnaphosidae between the two habitats. Though the area is described broadly as shortgrass steppe, the two habitats were very different in the amount of ground cover (much less in the grass/shrub habitat), which probably influenced the microhabitat tolerances and mobility of the spiders.

Examples of species that were significant indicator species but were not among the dominant taxa (tables 3, 4) include L. hesperus and Z. karli in PJ, P. camawhitae and $H$. hola in PIPO, and T. terricola in MC. Useful indicator species for environmental categories (such as habitat type) can be overlooked if only the dominant taxa are examined. We do not yet have a complete understanding of the factors influencing spider habitat occurrences.

Consistent among habitats and locations in our study was the high relative abundance of immature-stage individuals, which generally cannot be assigned to a species, but can be a large part of spider biomass in a given area (Weeks and Holtzer, 2000), creating difficulties in assessing richness and turnover (Norris, 1999; Jimenez-Valverde and Lobo, 2006). Immature stages were included in the lists of dominant taxa for each habitat type (table $3 A-C$ ) to show their importance in relative abundance, but were excluded from the MDS to clarify habitat associations (an MDS including immature stages did not alter the overall patterns; data not shown).

An interesting result from this study was the greater overlap in spider species between PJ and PIPO habitats, rather than between PIPO and MC (appendix), which appeared to be more similar in vegetation structure to each other than to PJ. A possible explanation is the shared geologic and climatic history of the PJ and PIPO habitat types in the southwestern U.S. About 14,000 yr. before present (B.P.) subalpine forests were found at elevations below 2,300 $\mathrm{m}$ (Anderson and others, 2008b) in parts of the southwestern U.S., so that these forests covered a much wider area than they do today (compare with our current habitat types, fig. 1, table 1). By 11,500 yr B.P. the climate had warmed, causing a retreat of mixed-conifer plant species; summer monsoon rains also increased, which allowed ponderosa pine, oaks, and piñon pine to move into some of the areas vacated by mixed-conifer species (Toney and Anderson, 2006; Anderson 2008b). Under these conditions the spider species from PJ and PIPO sites perhaps arrived in the area at about the same time, while the MC species were retreating with the wetter forests.

The southern Rocky Mountains and Colorado Plateau form an ideal landscape in which to study the distributions of higher-elevation arthropod species, as forested areas that are more connected in the Rockies become increasingly fragmented on the Colorado Plateau. Species may be "filtered" out by fragmentation (isolation) and (or) a warmer, drier climate (Wiescher and others, 2012). Such studies will allow us to predict distribution changes due to global warming, which is expected to increase temperatures and extreme climate events in the southwestern U.S. (Diffenbaugh and Ashfaq, 2010). While much work remains in understanding regional patterns in spider communities in the southwestern U.S., the cumulative results of this study and others (Lightfoot and others, 2008; Higgins and others, 2014) are steadily leading to a more complete picture.

\section{Acknowledgments}

We thank Craig Allen and Kay Beeley of Bandelier National Monument for their continued support of the long-term arthropod study there; Jason McVay for PRISM meteorological data; and Barbara Ralston, Mike Draney and David Richman for constructive reviews that improved the paper. Brad Butterfield and Carrie Cobb both provided insightful comments on the manuscript. We acknowledge the support of NSF grant EF-1207371 for the Symbiota/SCAN database. 


\section{References Cited}

Anderson, M.J., Gorley, R.N., and Clarke, K.R., 2008a, PERMANOVA for PRIMER - Guide to software and statistical methods: Plymouth, UK, PRIMER-E Ltd, 214 p.

Anderson, R.S., Jass, R.B., Toney, J.L., Allen, C.D., CisnerosDozal, L.M., Hess, M., Heikoop, J., and Fessenden, J., 2008b, Development of the mixed conifer forest in northern New Mexico and its relationship to Holocene environmental change: Quaternary Research, v. 69, p. 263-275.

Bowden, J.J., and Buddle, C.M., 2010, Spider assemblages across elevational and latitudinal gradients in the Yukon Territory, Canada: Arctic, v. 63, p. 261-272.

Bradley, R.A., 2013, Common spiders of North America: Berkeley, Calif., University of California Press, 271 p.

Brown, D.E., ed., 1982, Biotic communities of the American Southwest-United States and Mexico: Desert Plants, v. 4, $342 \mathrm{p}$.

Chatzaki, M., Lymberakis, P., Markakis, G., and Mylonas, M., 2005, The distribution of ground spiders (Araneae, Gnaphosidae) along the altitudinal gradient of Crete, Greece-Species richness, activity and altitudinal range: Journal of Biogeography, v. 32, p.813-831.

Clarke, K.R., and Gorley, R.N., 2006, PRIMER v.6-User manual/tutorial: Plymouth, UK, PRIMER-E Ltd, 192 p.

Crawford, C.S., 1989, Assemblage organization of surfaceactive arthropods in Sonora Desert dune ecosystems: Acta Zoologica Mexicana, v. 34, p. 1-28.

Diffenbaugh, N.S., and Ashfaq, M., 2010, Intensification of hot extremes in the United States: Geophysical Research Letters, v. 37, L15701, doi:10.1029/2010GL043888.

Ellis, L.M., Crawford, C.S., and Molles, M.C., Jr., 2001, Influence of annual flooding on terrestrial arthropod assemblages of a Rio Grande riparian forest: Regulated Rivers Research and Management, v. 17, p.1-20.

Ellis, L.M., Molles, M.C., Jr., Crawford, C.S., and Heinzelmann, F., 2000, Surface-active arthropod communities in native and exotic riparian vegetation in the Middle Rio Grande Valley, New Mexico: Southwestern Naturalist, v. 45, p. 456-471.

Goff, F., 2009, Valles Caldera-A geologic history: Albuquerque, University of New Mexico Press, 114 p.

Higgins, J.W., Cobb, N.S., Sommer, S., Brantley, S., and Delph, R., 2014, Ground-dwelling arthropod responses to succession in a pinyon-juniper woodland: Ecosphere, v. 5, no. 1, available at http://dx.doi.org./10.1890/ES13-00270.1.
IBM Corp., 2013, IBM SPSS statistics for Windows, ver. 22.0: Armonk, New York.

Jimenez-Valverde, A., and Lobo, J.M., 2006, Establishing reliable spider (Araneae, Araneidae and Thomisidae) assemblage sampling protocols-Estimation of species richness, seasonal coverage and contribution of juvenile data to species richness and composition: Acta Oecologica, v. 30, p. $21-32$.

Körner, C., 2007, The use of 'altitude' in ecological research: Trends in Ecology and Evolution, v. 22, p. 569-574.

Lightfoot, D.C., Brantley, S.L., and Allen, C.D., 2008, Geographic patterns of ground-dwelling arthropods across and ecoregional transitions in the North American southwest: Western North American Naturalist, v. 68, p. 83-102.

Mallis, R.E., and Hurd, L.E., 2005, Diversity among grounddwelling spider assemblages-Habitat generalists and specialists: Journal of Arachnology, v. 33, p. 101-109.

Masta, S.E., 2000, Phylogeography of the jumping spider Habronattus pugillis (Araneae: Salticidae)—Recent vicariance of sky island populations?: Evolution, v. 54, p. 1699-1711.

McCune, B., Grace, J., and Urban, D.L., 2002, Analysis of ecological communities: Gleneden, Oregon, MjM Software Design.

Merriam-Powell Center for Environmental Research, 2014, C Hart Merriam elevation gradient climate stations: MerriamPowell Center for Environmental Research, accessed April 7, 2014, at http://perceval.bio.nau.edu/MPCER_OLD/ gradient/wx.php.

Norris, K.C., 1999, Quantifying change through time in spider assemblages-Sampling methods, indices and sources of error: Journal of Insect Conservation, v. 3, p. 309-325.

Otto, C., and Svensson, B.S., 1982, Structure of communities of ground-living spiders along altitudinal gradients:

Holarctic Ecology, v. 5, p. 35-47.

Parmenter, R.R., Brantley, S.L., Brown, J.H., Crawford, C.S., Lightfoot, D.C., and Yates, T.L., 1995, Diversity of animal communities on southwestern rangelands: species pattern, habitat relationships, and land management in West, N., ed., Biodiversity on rangelands-Natural resources and environmental issues, v. 4: Logan, Utah State University, College of Natural Resources, p. 50-71.

Priest, S.S., Duffield, W.A., Malis-Clark, K., Hendley, J.W., II, and Stauffer, P.H., 2001, The San Francisco Volcanic Field, Arizona: U.S. Geological Survey Fact Sheet 017-01, 2 p., available at http://pubs.usgs.gov/fs/2001/fs017-01/ fs017-01.pdf. 
PRISM Climate Group, 2014, Descriptions of PRISM Spatial Climate Datasets for the Conterminous United States: PRISM Climate Group, Oregon State University, accessed February 22, 2014, at http://www.prism.oregonstate.edu/ documents/PRISM_datasets.pdf.

Rahbeck, C., 1995, The elevational gradient of species richness - a uniform pattern: Ecography, v. 18, p. 200-205.

Rehfeldt, G.E., Crookston, N.L., Warwell, M.V., and Evans, J.S., 2006, Empirical analyses of plant-climate relationships for the western United States: International Journal of Plant Sciences, v. 167, p. 1123-1150.

Rehfeldt, G.E., Ferguson, D.E., and Crookston, N.L., 2009, Aspen, climate, and sudden decline in western USA: Forest Ecology and Management, v. 258, p. 2353-2364.

Ricketts, T.H., Dinerstein, E., Olson, D.M., Loucks, C.J., Eichbaum, W., DellaSala, D., Kavanagh, K., Hedao, P., Hurley, P., Carney, K.M., Abell, R., and Walters, S., 1999, Terrestrial ecosystems of North America-A conservation assessment: Washington, D.C., Island Press, 485 p.

Roughley, R.E., Pollock, D.A., and Wade, D.J., 2006, Biodiversity of ground beetles (Coleoptera: Carabidae) and spiders (Araneae) across a tallgrass prairie - aspen forest ecotone in southern Manitoba: Canadian Entomologist, v. 138 , p. 545-567.
Toney, J.L., and Anderson, R.S., 2006, A postglacial palaeoecological record from the San Juan Mountains of Colorado USA - Fire climate and vegetation history: Holocene, v. 16, p. 505-517.

Uetz, G.W., 1991, Habitat structure and spider foraging, in Bell, S.S., McCoy, E.D., and Mushinsky, H.R., eds., Habitat structure-The physical arrangements of objects in space: London, Chapman and Hall, p. 325-348.

Vankat, J.L., 2013, Vegetation dynamics on the mountains and plateaus of the American Southwest-Plant and Vegetation, v. 8: New York, Springer, 461 p.

Weeks, R.D., Jr., and Holtzer, T.O., 2000, Habitat and season in structuring ground-dwelling spider (Araneae) communities in a shortgrass steppe ecosystem: Environmental Entomology, v. 29, p. 1164-1172.

Wiescher, P.T., Pearce-Duvet, J.M.C., and Feener, D.H., 2012, Assembling an ant community-Species functional traits reflect environmental filtering: Oecologia, v. 169, p. 1063-1074.

Wise, D.H., 1993, Spiders in ecological webs: Cambridge, UK, Cambridge University Press, 328 p. 
Appendix 
Appendix. List of taxa and total specimen numbers collected at the San Francisco Peaks (SFP) and Bandelier National Monument (BAND) sites by habitat.

[PJ, piñon-juniper; PIPO, ponderosa pine; MC, mixed-conifer; imm., immature individuals]

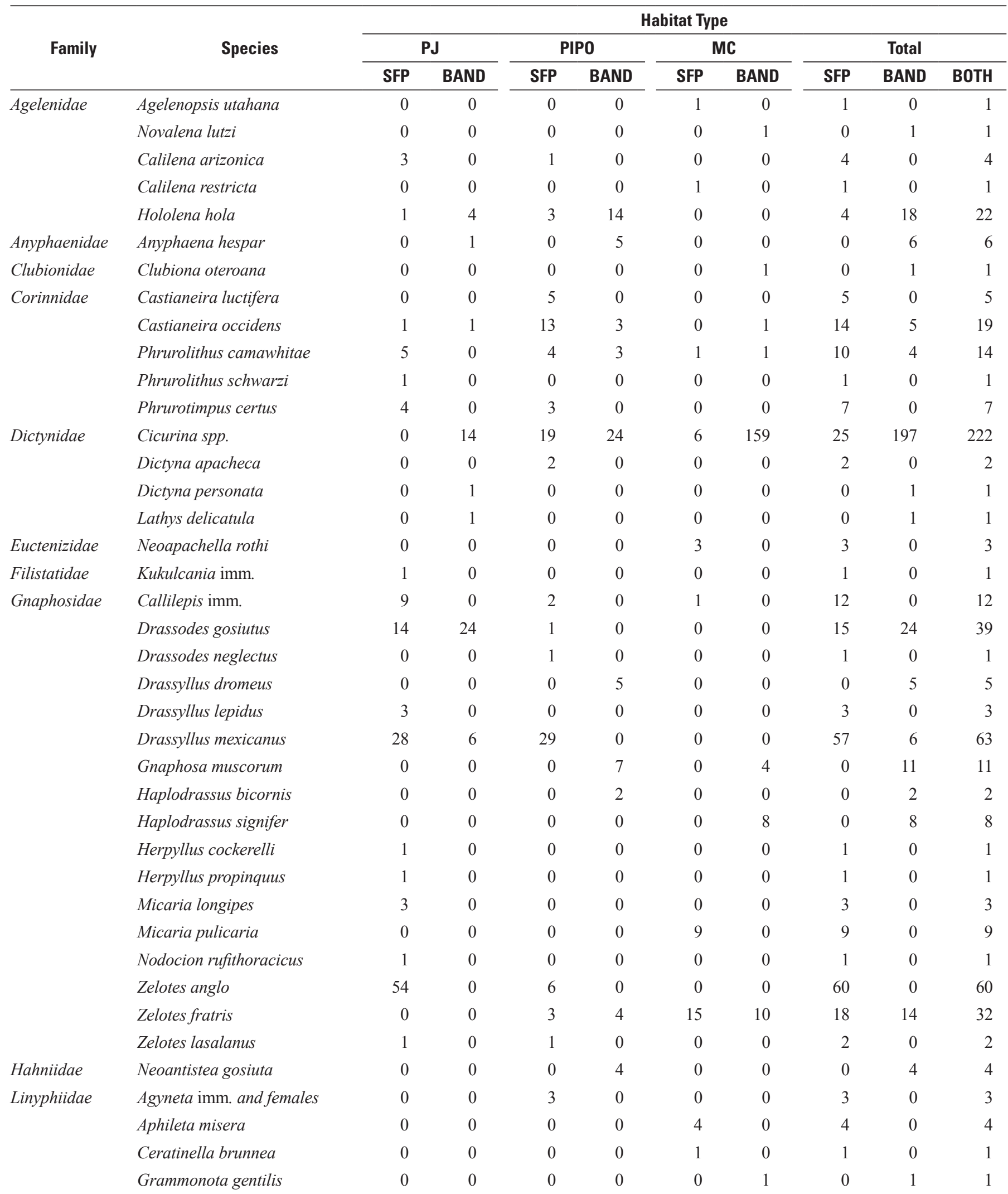


Appendix.-Continued

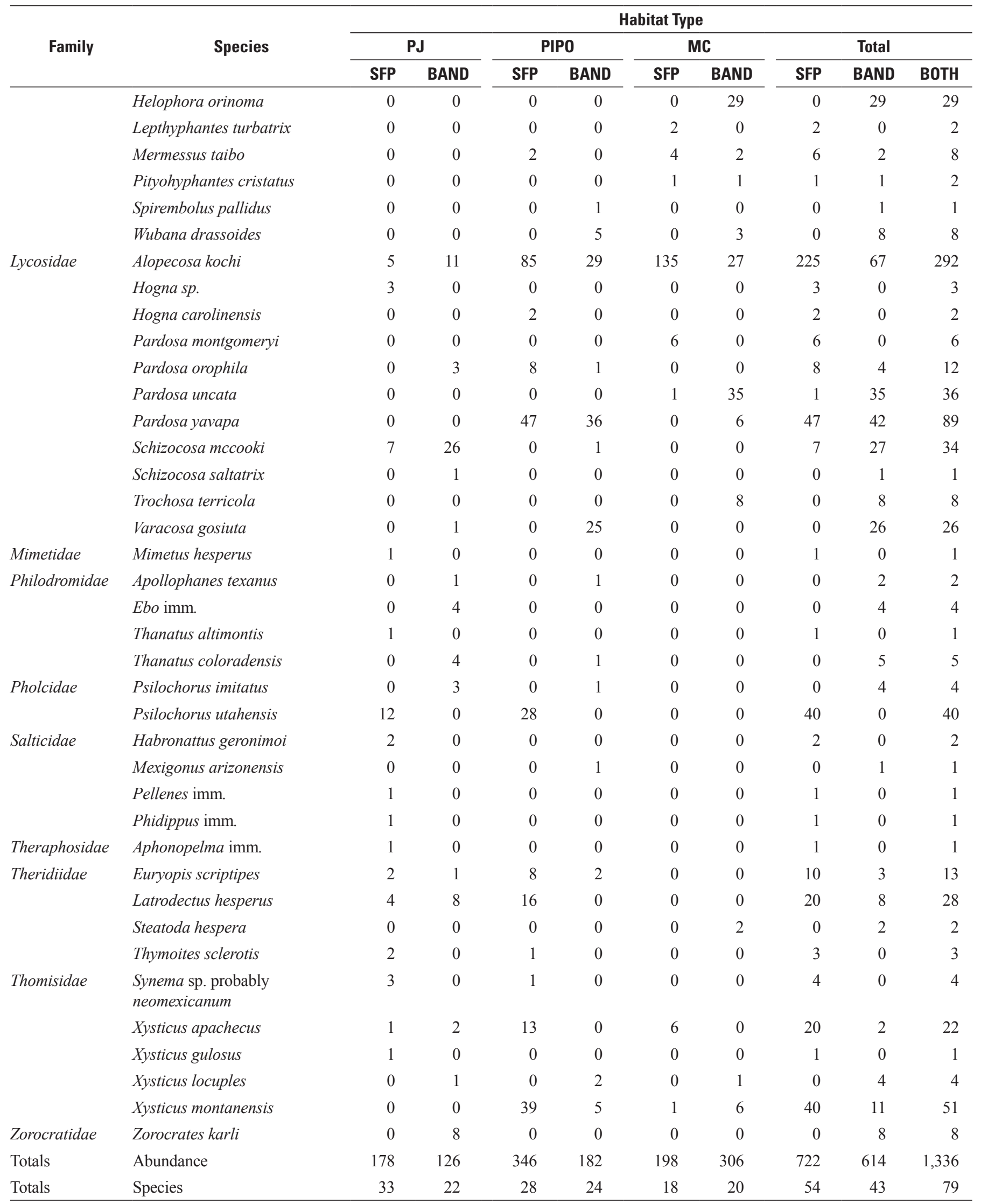




\title{
Chapter H
}

\section{Effects of Changing Lake Level on Lake Powell Fisheries-A Hypothesis}

\author{
By A. Wayne Gustaveson ${ }^{1}$
}

\section{Abstract}

Lake Powell fisheries are greatly influenced by changes in lake level and nutrient concentrations. Various fish species can be stocked, but lake conditions determine which species thrive. Largemouth bass (Micropterus salmoides) depend on inundated terrestrial vegetation for spawning and nursery cover, and thrive or decline based on the amount of brush in the water. Abundant threadfin shad (Dorosoma petenense) allow striped bass to grow and reproduce without limit. Predation from an overpopulation of striped bass eliminates pelagic shad, causing a decline in the health and reproductive success of striped bass. Threadfin shad are dependent on plankton that is abundant near inflowing tributary water. Sediment and nutrients transported by spring runoff settles out near the plunge point where the river enters the lake. Nutrients available for plankton production are transported throughout the main stem of the lake by overflowing density currents. The side canyon nutrient transport is impacted in the same manner by a flash flood event. It takes a reservoir-wide event such as a high flow event to impact all the side canyons simultaneously and increase plankton and shad production.

\section{Introduction}

Lake Powell is located on the Utah-Arizona state line where the Colorado River crosses the border. Lake Powell is the second largest reservoir by volume in the United States when it is at full pool. The reservoir was impounded by Glen Canyon Dam beginning in March 1963, and the initial filling was completed by June 1980. With over 3,000 kilometers (km) of shoreline, Lake Powell has a surface area of 65,960 hectares (ha). Full pool elevation is 1,128 above mean sea level with a maximum water depth at the dam of 170 meters (m).

The reservoir stratifies in the summer months with an inflow current overflowing a denser bottom layer. Stratification typically breaks down in November due to convective mixing

${ }^{1}$ Utah Division of Wildlife Resources and advective currents. Due to the great depth $(170 \mathrm{~m}$ at full pool) at the lower end of the lake, the water below the penstocks remains homogenous and separate from the water above. During winter a cold, dense inflowing current sometimes moves along the bottom and over time displaces this layer up and through the penstocks. Average water retention time for the reservoir is two years, however it is only eight months for the upper part of the lake. This is due not only to the shallower water depth, which is more susceptible to convective mixing, but also the proximity to the Colorado River, which allows for more lateral circulation (Potter and Drake, 1989).

Two major droughts have affected the reservoir in the last 20 years. The first began in the mid-1980s and lasted until 1992; the second began in 1999 and ended in 2005. Drought results are tracked by annual water level fluctuations (fig. 1). The second drought, in particular, appears to have had a profound effect on the water chemistry of the lake, affecting productivity and the fishery (Vernieu, 2009, 2010).

Recently, water has been released from the Glen Canyon Dam in "high flow events" to transport sediment deposited near the dam downstream towards the Grand Canyon in order to rebuild beaches that have been eroded due to fluctuating flow patterns. The high flow events (HFE) occurred in 1996, 2004, 2008, and 2013. The 1996 high flow event featured flows of $1.273 \mathrm{~m}^{3} / \mathrm{s}$ sustained for 7 days. The elevation of Lake Powell dropped $3 \mathrm{~m}$ during the flood event. In November 2004 a 60 -hour high flow event with an outflow of $1.16 \mathrm{~m}^{3} / \mathrm{s}$ dropped the lake level almost $1 \mathrm{~m}$. The third HFE occurred March 5-7, 2008, with similar flows of $1.17 \mathrm{~m}^{3} / \mathrm{s}$ and dropped the elevation of Lake Powell almost $1 \mathrm{~m}$.

\section{Methods}

Pelagic sampling for shad has historically been conducted by tow survey on Lake Powell by the Utah Division of Wildlife Resources, Lake Powell Project crew, utilizing a 1-m-wide net to quantify larval shad production in the backwater at the heads of selected canyons, and a midwater depth trawl-net survey that measured the quantity of open-water shad populations.

Larval shad tow gear consisted of a 500-micron mesh net with a $1-\mathrm{m}$ circular open end, tapering to 76.2 millimeter (mm) 
diameter at the cod-end. The overall net length was $3 \mathrm{~m}$, with a detachable cup for fish removal on the terminal end. The net was towed at a speed that allowed it to suspend just below the surface for 2 minutes. Approximately $102 \mathrm{~m}^{3}$ of water was sampled in each tow. Three to six tows were performed at each station with the goal of bringing the coefficient of variation of the mean catch to 0.20 or less based on recommendations by Boxrucker and others (1995). Down-lake tow sites were at Wahweap Creek, Warm Creek, and Navajo Canyon. Midlake sites were primarily at Bullfrog Creek and Halls Creek. Historically, Red Canyon and Ticaboo Creek were the most consistently sampled up-lake sites, but we have since shifted to sampling at Red Canyon and Trachyte Creek. These sites were selected based on declining water levels near the Colorado River inflow. The new sites consistently had inflow during the threadfin shad spawning season and, in most cases, were in close proximity to open water trawl sampling stations. In conjunction with the tows, surface temperature and secchi disk readings were obtained.

Mid-water trawl was used to sample the pelagic part of the threadfin shad population. The annual survey began in 1976 with equipment based on a design described by Von Geldern (1972). The net had a $3.048 \mathrm{~m}^{2}$ opening, was $15.24 \mathrm{~m}$ long with 20.3 centimeter $(\mathrm{cm})$ bar-mesh tapering to $3 \mathrm{~mm}$ mesh at the terminal end. Lead weighted steel depressors were attached to the lower corners, and aluminum hydrofoils with attached cork floats were fastened to the top corners to float and spread the net opening. Each tow consisted of spooling the net out for $61 \mathrm{~m}$, then immediately retrieving it while running the boat at $1,100 \mathrm{rpm}$. This produced an oblique tow that sampled from the surface to a depth of $10 \mathrm{~m}$. The water volume sampled was 8,178 square meters $\left(\mathrm{m}^{3}\right)$.

Three standard trawl stations were established at Wahweap Bay, Bullfrog Bay, and Good Hope Bay following the main channel of the lake. A station on the San Juan arm of the lake was also sampled when lake elevations and logistics permitted. Sampling was done after dark, during the period of the new moon in July and August. At least three tows were conducted at each site. Results from the three sampling sites were averaged to provide a standard shad abundance figure for each year.

The standardized November gill-netting survey has been conducted in its present form since 1981. From 1975 to 1981 the same gill-net survey was conducted during March instead of November. The survey sites include four stations at Warm Creek/Wahweap Bay (down-lake), Rincon (mid-lake), Red Canyon at Good Hope Bay (up-lake), and the Piute Canyon/ Neskahi Wash area on the San Juan arm. Nets were deployed for two consecutive nights at each location. Total length and weight were obtained from all fish sampled. Additional information was obtained on certain target species including sex, stomach contents (percent occurrence), fat index, parasite index, and scale samples for aging.

The survey utilized 10 experimental, sinking-style gill nets at each location. Each net consisted of four panels with progressively increasing bar mesh sizes of 19, 25.4, 38.1, and $50.8 \mathrm{~mm}$, respectively. Nets were attached to the shore, alternating large and small mesh sizes on the inshore side. Nets were set in a perpendicular orientation to shore with the open-water end usually at a 6 to $21 \mathrm{~m}$ depth range.

Sampling for striped bass consists of a young-of-year (YOY) electrofishing survey conducted in September and the annual gill-netting survey in November. Relative abundance of YOY striped bass and length information were collected from the electrofishing survey. The gill-netting survey yields information on relative abundance, total length, weight, condition, fat index, diet information, and sex. Scale samples are used for age and growth analysis.

The condition of striped bass is based on Fulton's condition factor, $\mathrm{K}$, which assumes that the standard weight of a fish is proportional to the cube of its length. In sampling Lake Powell striped bass we have chosen to use

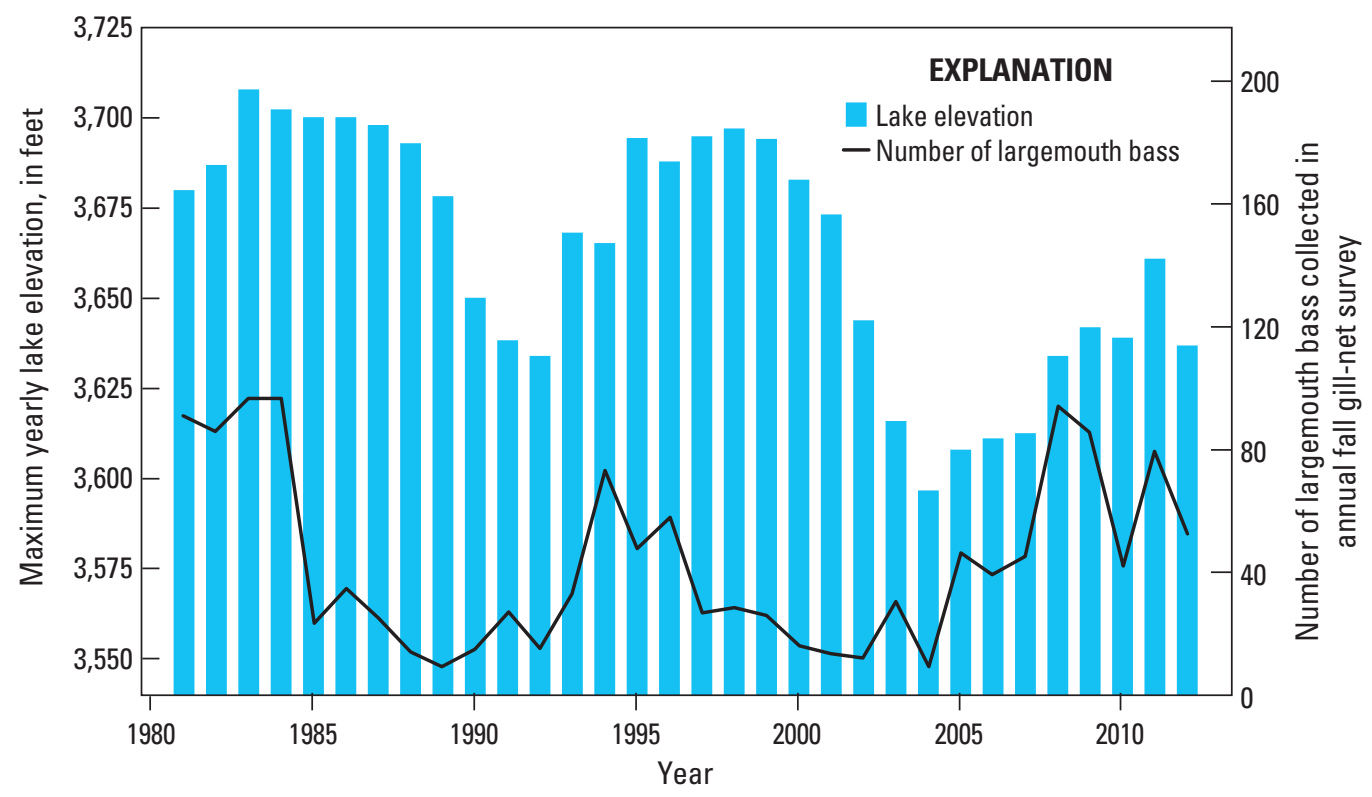

Figure 1. Graph of the maximum yearly lake elevation compared to largemouth bass abundance, Lake Powell, Utah, 1981-2012. 
the fork length instead of total length, hence the term Kfl when discussing relative robustness of individual fish. This description is consistent throughout our long-term studies beginning in 1974. Black bass species are defined using the term " $\mathrm{K}$ " which means condition is based on total length instead of fork length.

Water levels at Lake Powell and all reservoirs in the Colorado River system are collected daily by the Bureau of Reclamation (BOR) and posted on their website (http://www. usbr.gov/uc/water/rsvrs/ops/crsp_40_gc.html). Water levels found in this report come from BOR statistics.

\section{Results and Discussion}

\section{Largemouth Bass}

Shortly after Lake Powell was impounded in 1963 almost one million largemouth bass (Micropterus salmoides) were stocked, followed by another two million largemouth bass fry in 1964 (Stone and others, 1965). These stockings proved to be adequate for largemouth bass to dominate the Lake Powell sport fishery for the next 20 years (Blommer and Gustaveson, 2014). Each spring the lake level would increase, covering new terrestrial vegetation, and allowing bass to use submerged brush as spawning and nursery cover. These species thrived while other stocked fish, rainbow trout (Oncorhynchus mykiss) and kokanee salmon (Oncorhynchus nerka), struggled in an inhospitable environment. Trout could be stocked annually to maintain a put-grow-and-take fishery, but successful reproduction was uncommon due to silty river bottoms that smothered eggs on nests built in inflowing streams. Kokanee salmon were stocked in 1963 and 1964, but were never recorded as being caught by anglers or sampled in fish collection gear thereafter (Gloss and others, 1971). Seven native fish species that thrived in the Colorado River prior to impoundment were poorly suited for life in the new reservoir environment (Gustaveson and Blommer,
2013). Within five years, only a few individual native fish remained in the flat water of the lake, with most native fish disappearing. Presently, only an occasional flannelmouth sucker (Catostomus latipinnis), razorback sucker (Xyrauchen texanus), or Colorado pikeminnow (Ptychocheilus lucius) remain at the inflow waters where tributaries enter the lake (Blommer and Gustaveson, 2014).

Threadfin shad (Dorosoma petenense) were stocked in 1968 and 1969 to provide forage for all game fish and in anticipation for stocking of striped bass that occurred in 1974. Shad were immediately preyed on by all lake predators and increased the growth and condition of game fish species. Shad have been the primary food source of striped bass from initial stocking to the present day.

Lake Powell filled in 1980 and water levels began fluctuating thereafter. Shoreline vegetation was no longer covered by rising water each spring; declining water levels, combined with wind and wave action eliminated terrestrial vegetation in the reservoir fluctuation zone. Without vegetation to use as nursery cover, the largemouth bass populations also declined (Bryan and Scarnecchia, 1992).

During the 1980s, largemouth bass remained low in number until the drought of 1988-92 reduced the lake level and allowed terrestrial vegetation enough time to grow and develop before the lake level rebounded in 1993 (fig. 1). Rising water again flooded new terrestrial vegetation including tamarisk and native willow. Largemouth bass responded as the few remaining adults used the new habitat for spawning and nursery cover. Largemouth bass YOY numbers increased to higher levels and maintained that peak in abundance from 1994 to 1996 (fig. 2).

The lake level again stabilized in 1996, but then fluctuated through the end of the decade. Fluctuation again reduced vegetation, resulting in poor survival of young largemouth bass. Numbers declined back to the range seen prior to the previous drought.

The relation of bass population to brush was again demonstrated during the next drought cycle. From 2000 to 2004, largemouth bass numbers were lower than the long-term average; as brush was covered by rising water in spring 2005 ,

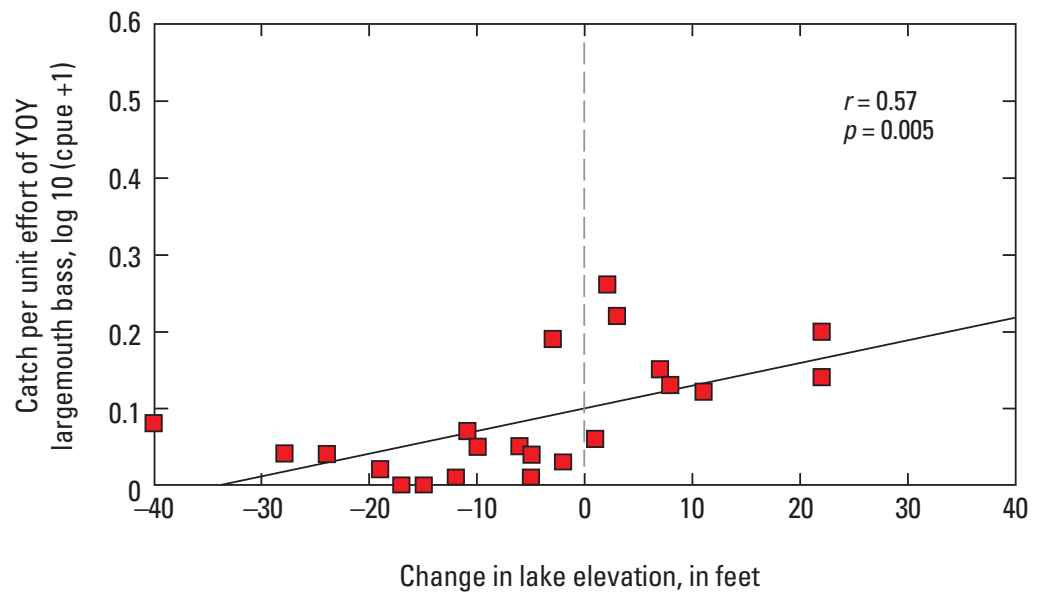

Figure 2. Graph of correlation between the maximum lake level and the catch of young-of-year largemouth bass in the annual electrofishing survey, 1988-2012. 
largemouth bass numbers rose. As the lake level continued to rise each spring through 2008 , bass numbers increased to the same levels ( 95 bass/gillnet in 2008 and 97 bass/gillnet in 1984) seen when the lake originally filled in 1980 and overfilled in 1984 (fig. 1). Thus, it was demonstrated once more that bass rely on vegetation for nursery cover. When submerged brush of the right variety is available, largemouth bass thrive; without brush in the water, bass numbers decline.

\section{Striped Bass}

Striped bass (Morone saxatilis) were stocked in Lake Powell beginning in 1974. Stocking was curtailed in 1979 after natural reproduction was discovered. Prior to introduction it was expected that some limited natural reproduction would occur, according to literature references at the time of stocking (Gustaveson and Blommer, 2013). The original expectation was that striped bass would not be able to produce enough young to provide a significant sport fishery, which would have to be maintained by annual stocking.

The magnitude of reproduction proved to be exactly the opposite, with unprecedented survival rates of striped bass in Lake Powell. Striped bass size and numbers increased dramatically in the early 1980s. The lake's top level predator grew quickly by feeding on the previously unexploited threadfin shad (Dorosoma pentenense) population. The growth in size and number of striped bass continued until the shad population was eliminated from open water and forced to hide in shallow thermal refuges to avoid striped bass predation. The striped bass limiting factor then became shad availability (fig. 3).

Shad persisted in warm thermal refuges in turbid water in the backs of many canyons where striped bass foraging success was limited. Growth of striped bass decreased during periods of low shad forage (Gustaveson, 1999); adult striped bass suffered from malnutrition (Kfl less than 1.0) when shad resources were low or absent in open water (fig. 4).

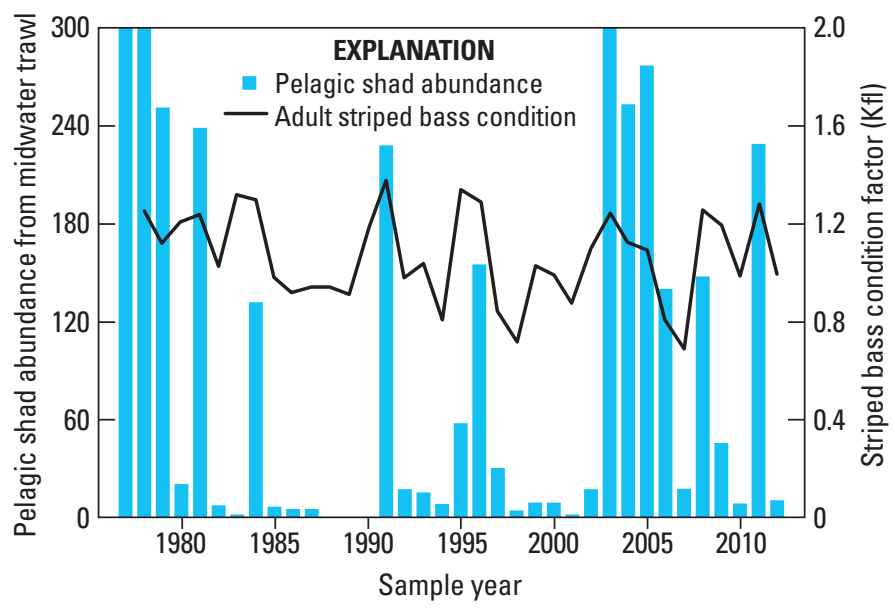

Figure 3. Graph of pelagic shad abundance (midwater trawl) compared to adult striped bass condition (Kfl), 1976-2013.

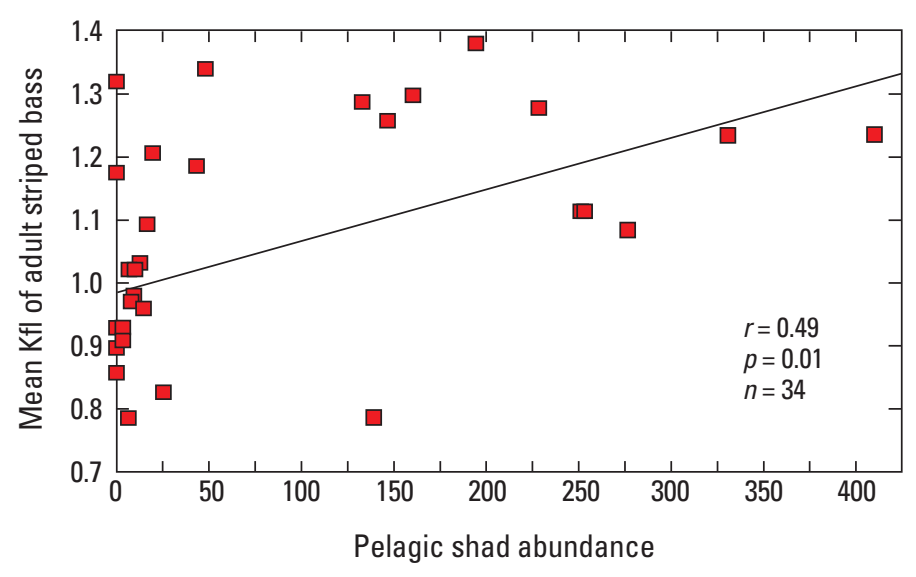

Figure 4. Graph of correlation between mean condition of adult striped bass (Kfl) and pelagic shad abundance from trawl tows, 1979-2012.

Juvenile striped bass were always present in large numbers and able to maintain healthy body condition by foraging on zooplankton when shad were absent. When Lake Powell shad abundance increased, adult striped bass growth, condition, and reproductive ability immediately improved.

\section{Shad}

Open water shad abundance was high during the 1970s preceding striped bass establishment. From 1982 to 2002, shad abundance peaks in open water were rare. This suggests that intense striped bass predation reduced shad numbers from the open water zones where trawl sampling was conducted.

Modest shad abundance peaks did occur unexpectedly on a few occasions. During the 1980s and 1990s, open water shad abundance peaked at levels higher than 120 shad/midwater trawl haul in 1984, 1991, and 1996. Shad abundance peaks occurred more often from 2003 to 2010 but these peaks consisted mostly of open water gizzard shad (Dorosoma cepedianum) (unintentionally introduced in 2000) mixed with threadfin shad that were responsible for peaks in the previous decades.

\section{High Flow Events (HFE)}

It is interesting to note that modest shad abundance peaks occurred each year that a high flow event (HFE) release from Glen Canyon Dam occurred (fig. 5). HFE releases were conducted in March 1996, November 2004, March 2008, and November 2013. It is possible that nutrients important to plankton production were transported into open water by the quick drop of $0.75 \mathrm{~m}$ in lake level. It is suggested that shad production is greater if the HFE is conducted in the springtime, when shad are spawning, instead of in the fall after spawning is complete.

The magnitude and dynamics of these flood events are described in several U.S. Geological Survey reports (Vernieu, 2009, 2010). However. the possible impact on Lake Powell 
fish can be summarized by anecdotal evidence found during the March 2008 flood event. Nitrogen and phosphorus nutrient levels were sampled in Navajo Canyon before and after the event. Nutrient concentrations upstream, toward the tributary inflow of Navajo Creek, increased after the HFE (Bill Vernieu, Glen Canyon Monitoring and Research Center, oral commun., 2013). Further details of profiling methodologies and sampling protocols are described in Vernieu (2009). Although the increases in nitrogen and phosphorus were not statistically significant, they were attributed to the resuspension of deltaic sediments in the upper end of the tributary. The short-term drawdown during the HFE may result in similar increases in nutrient concentrations and primary productivity. Therefore, it is possible that high-release operations at Glen Canyon Dam, which result in significant drawdown of the reservoir during a short period of time, may result in similar nutrient increases in the tributary arms of the reservoir, and may cause subsequent increases in productivity in the tributary arms and the reservoir in general. The results of the Navajo Canyon transect sampling, although not robust enough to show statistical significance, reflect anecdotal conditions before and after the HFE; while indicating that nutrient concentrations are higher near the inflows of tributaries, as is commonly seen at Lake Powell, they also indicate further increases in nutrient concentrations as a result of the short-term drawdown of the reservoir during the HFE (Bill Vernieu, GCMRC, oral commun., 2013).

It is important to determine if inflowing currents travel across the surface of the reservoir, rather than plunging to deeper layers. After the HFE, on March 11, 2008, higher dissolved oxygen (DO) concentrations were observed in an approximately $30-\mathrm{m}$-thick layer at the bottom of the reservoir. This represents the winter inflow density current approaching

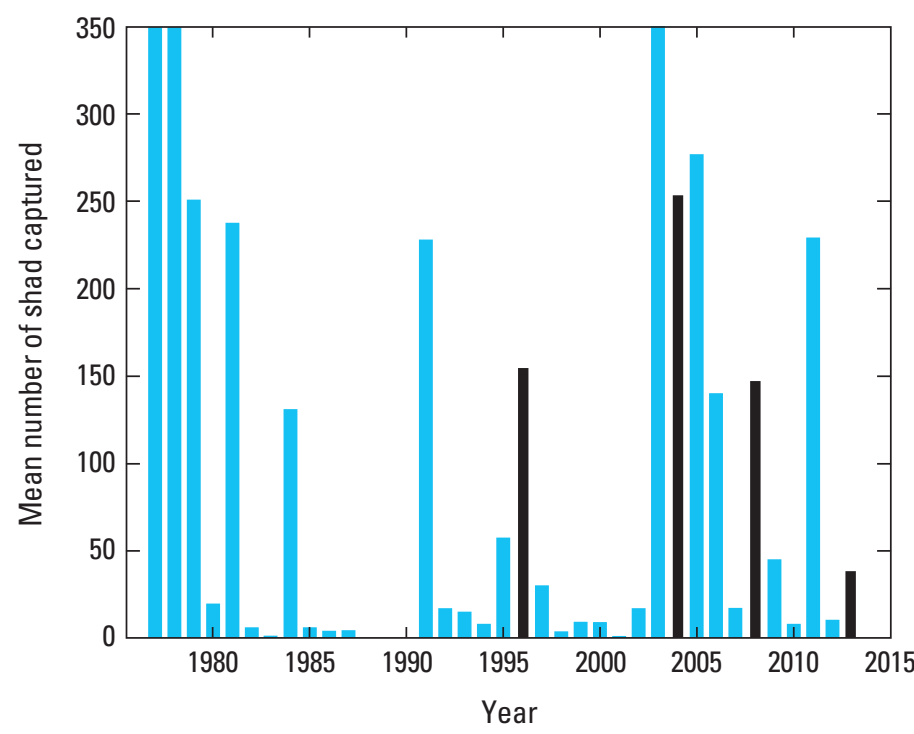

Figure 5. Annual shad abundance (midwater trawl) with high flow years (1996, 2004, 2008, and 2013) highlighted in black.
Glen Canyon Dam that was not present in the pre-HFE profile. No discernable differences were observed at the penstock withdrawal depth (Vernieu, 2010).

Isopleths of temperature, specific conductance, and DO, pre- and post-HFE, show the stratification in the reservoir below the mixed epilimnion, the progressive movement of the inflow density current through the reservoir, and the gradual evacuation of the previous year's hypolimnion (Vernieu, 2010). When conditions are right, an HFE may result in increased production of fish and a refreshing of the stagnant layers of water near the dam.

\section{Summary and Conclusions}

Lake level fluctuations play a large role in determining which species of fish thrive in the lake while others barely survive. Lake stabilization at full pool creates a fluctuation zone where terrestrial vegetation is absent. Declining water levels expose previously flooded terrestrial vegetation to wind and wave action that tends to uproot plants in sandy soil. Refilling into the same 7-m-zone following the next spring flood does not allow enough time for new vegetation to grow. The result is a sandy beach with little or no brush to be used as fish habitat.

Without submerged vegetation, brush-loving species find little habitat for spawning and nursery cover. Largemouth bass do not thrive in these conditions. Extended drought that causes the lake level to decline also allows more brush to grow along the new, lower elevation lakeshore. A resurgence of brush-loving fish occurs after the lake overtakes fast-growing terrestrial vegetation, such as tamarisk (Tamarix ramosissima), which is used as spawning and nursery habitat.

Fish not dependent on submerged brush, like striped bass and threadfin shad, depend on other factors for optimum survival. Striped bass depend on open-water shad production. When shad numbers are high, open-water predators thrive. When shad numbers decline, the total number and physical condition of pelagic predators decline.

Shad abundance is greatly influenced by plankton availability. Circumstances such as resuspension of deltaic sediment that release nutrients previously unavailable due to sediment coverage can enhance a shad year class when resuspension occurs just prior to, or during, the shad spawning period. Spring runoff from the tributaries enhances lake productivity each year, but inflowing sediment that contains important nutrients often settles out of the water column and some of the nutrients are then covered by a sediment delta. Those nutrients flowing into the reservoir that remain in suspension are transported through the main stem of the reservoir by overflowing density currents. The side canyons are less affected by density current flow unless a perennial stream occurs in that canyon.

Resuspension of deltaic sediment by flash flood events can increase nutrients in each canyon where flash floods occur. It takes a lake-wide event, such as the rapid decline 
in reservoir level that occurs during an HFE, to enhance nutrient levels in all 96 major side canyons simultaneously. An event of that magnitude can increase plankton production, which is then followed by an increase in pelagic shad. The end result is a positive impact on the Lake Powell food chain and total fish numbers.

\section{References Cited}

Blommer, G.L., and Gustaveson, A.W., 2014, Lake Powell fisheries investigations completion report-May 2010April 2013: Salt Lake City, Utah Department of Natural Resources, Division of Wildlife Resources, Publication no. 14-0, $161 \mathrm{p}$.

Boxrucker, J., Degan, D., DeVries, D., Michaletz, P., Van Den Avyle, M., and Vondracek, B., 1995, Sampling shad in southern impoundments: U.S. Fish and Wildlife Service and American Fisheries Society, Special publications sponsored by USFWS and Reservoir Committee of the Southern Division, AFS, 22 p.

Bryan, M.D., and Scarnecchia, D.L., 1992, Species richness, composition, and abundance of fish larvae and juveniles inhabiting natural and developed shorelines of a glacial Iowa lake: Environmental Biology of Fishes, v. 35, no. 4, p. 329-341, accessed October 2013, at http://dx.doi. org/10.1007/BF00004984.

Gloss, S.P., Starostka, V., and Thompson, C., 1971, Glen Canyon Reservoir post impoundment report: Salt Lake City, Utah Division of Wildlife Resources, 18 p.
Gustaveson, A.W., 1999, Cyclical population dynamics of self-sustaining striped bass in Lake Powell, Utah-Arizona, 1974-1998: Salt Lake City, Utah Division of Wildlife Resources, Sport Fish Restoration Act project F-46-R.

Gustaveson, A.W., and Blommer, G.L., 2013, History of striped bass management in the Colorado River, in Bulak, J.S., Coutant, C.C., and Rice, J.A., eds., Biology and management of inland striped bass and hybrid striped bass: Bethesda, Md., American Fisheries Society Symposium 80, p.15-23.

Potter, L.D., and Drake, C.L., 1989, Lake Powell—Virgin flow to dynamo: Albuquerque, University of New Mexico Press.

Stone, R., Fields, L., and Miller, K., 1965, Lake Powell post impoundment investigations: Utah State Department of Fish and Game, Glen Canyon Unit, Colorado River Storage Project, Progress report no. 2, Section 8 program, 35 p. [Also available at http://cwcbweblink.state.co.us/WebLink/ DocView.aspx?id=133590\&page $=20 \& \mathrm{dbid}=0$.]

Vernieu, W.S., 2009, Historical physical and chemical data for water in Lake Powell and from Glen Canyon Dam releases, Utah-Arizona, 1964-2013: U.S. Geological Survey Data Series 471, 23 p., accessed October 2013, at http://dx.doi. org $10.3133 /$ ds 471 .

Vernieu, W.S., 2010, Effects of the 2008 high-flow experiment on water quality in Lake Powell and Glen Canyon Dam releases, Utah-Arizona: U.S. Geological Survey Open-File Report 2010-1159, 25 p., accessed October 2013, at http:// pubs.usgs.gov/of/2010/1159/.

Von Geldern, C.E., Jr., 1972, A midwater trawl for threadfin shad, Dorosoma petenense: California Fish and Game, v. 58, no. 4, p. 268-276. [Also available at https://archive.org/stream/ californiafishga58_4cali/californiafishga58_4cali_djvu.txt.] 


\title{
Understanding Forest Restoration Effects on Water Balance: Study Design for the Four Forest Restoration Initiative Paired Watershed Study
}

\author{
By Frances C. O'Donnell,' Sharon Masek Lopez, ${ }^{1}$ and Abraham E. Springer ${ }^{1}$
}

\section{Abstract}

A legacy of past forestry and grazing practices, and a century of fire suppression in semiarid forests have led to declining forest health and an increasing incidence of larger and more severe wildfires, making it imperative to rapidly reduce forest density. Changes in vegetation cover after thinning may affect water balance in forests in the Salt and Verde River watersheds of central Arizona. This planned project will analyze forest restoration treatment effects at the catchment scale on water resources from forested lands in central Arizona, as well as the broader ecologic responses of forest structure, fuels and fire behavior, and vegetation. Comprehensive water balance data collected from a 12-site paired watershed study will quantify the effects of various restoration treatments and the efficacy of prescribed burning for maintaining postrestoration water yields. Results from the paired watershed study will be used to develop, parametrize, and verify hydrologic models in order to scale up predictions to the catchment scale. Products from this project will assist downstream water managers in forecasting and planning for water availability and sedimentation, and will be key components in the adaptive-management process being implemented for the Four Forest Restoration Initiative.

\section{Introduction}

A legacy of intensive logging and grazing practices, along with a century of fire suppression in the semiarid ponderosa pine forests of Arizona, have led to declining forest health and an increasing incidence of larger and more severe wildfires (Covington and Moore, 1994). The U.S. Forest Service is planning a decades-long, landscape-scale forest restoration project called the Four Forest Restoration Initiative (4FRI). Thinning to reduce tree density, along with the reintroduction of surface fire, is one of the most common approaches proposed for the restoration of ponderosa pine watersheds (Covington and

${ }^{1}$ Northern Arizona University others, 1997; Allen and others, 2002). In addition to reducing fire risk, a goal of 4FRI is to improve the hydrologic function and resilience of the forests that cover the watersheds of the Salt and Verde Rivers (U.S. Forest Service, 2011), an important water source for the Phoenix metropolitan area.

Altering vegetation cover affects the water balance mainly through changes in two processes: evapotranspiration (ET) and snow dynamics. Thinning in ponderosa pine forests results in an overall decrease in ET due to a reduction in overstory transpiration (Dore and others, 2012), although understory transpiration and soil evaporation may increase because of reduced interception and shading (Breshears and others, 1998; Simonin and others, 2007). Thinning typically increases snow accumulation by reducing canopy interception (Winstral and Marks, 2002) while, unlike in completely defoliated forests, sufficiently shading the snowpack to moderate melting rates (Seibert and others, 2010). Snow water input to soil moisture and runoff is a balance between interception and shading, and so it is generally highest in forests with intermediate canopy density (Musselman and others, 2008; Gustafson and others, 2010).

Paired watershed studies have commonly been used to evaluate the effects of forest management on hydrology. A paired watershed study utilizes two basins that are as similar as possible in terms of size, morphology, geology, soil type, climate, and land use. One watershed is treated, and the other is left as a control to determine watershed response to treatments (Hewlett and Pienaar, 1973; Andréassian, 2004). The best paired watershed studies test hypotheses and yield information about the hydrologic cycle that has applications beyond the local level. To evaluate water balance changes due to forest restoration treatments, a paired watershed study is required. Plot-based and other types of studies may address parts of the water balance (such as ET or soil water storage), but only a paired watershed study can examine the entire water balance (Clausen and Spooner, 1993).

Several paired watershed studies conducted in the 1950 s to 1980s have evaluated the effects of forest management on water yield and water quality in the semiarid forests of the Arizona highlands (Baker, 1999). Forest thinning treatments applied to mixed conifer ecosystems in two of three subbasins of the Workman Creek watershed were found to increase water yields (Rich and Gottfried, 1976), a result that was reproduced in three 
more pairs of mixed conifer (Thomas and Willow Creeks) and ponderosa pine (Castle Creek) forests on the White Mountains. Long-term monitoring at Castle Creek showed that the increases persisted for at least 21 years after thinning treatments designed to mimic commercial forest management (Gottfried and DeBano, 1990). The most extensive series of paired watershed experiments were conducted on 20 small catchments in the Beaver Creek Experimental Watershed in ponderosa pine and piñon-juniper ecosystems (Brown and others, 1974; Baker, 1986). The Beaver Creek studies found that both overstory removal and strip-cut thinning treatments that removed at least 30 percent of basal area resulted in significant increases in water yield, but, in contrast to the Castle Creek study, streamflow returned to pretreatment levels 4-10 years after treatment.

Past experimental watershed studies have provided a wealth of data on how forest management practices that were common at the time affected water yields. Over the past several decades, priorities for forest management have shifted, and silvicultural techniques have progressed, leading to a change in the forest treatment strategies that are used in the southwestern United States. Past forest management techniques were designed to maximize sustainable timber yield or to increase water yield (Baker, 1986; Gottfried and DeBano, 1990). Although wateryield improvement and economic gain from timber are still goals of forest management, they are parts of a more holistic view of ecosystem services that includes wildfire-risk reduction, restoration of presettlement conditions, reduction of soil erosion, improvement of wildlife habitat, and maintenance of recreational lands (U.S. Forest Service, 2011). This suite of priorities is better served by newer treatment methods (U.S. Forest Service, 2013), the effects of which have not yet been investigated. In light of conflicting results from past studies regarding the persistence of yield increases, further study of the recovery of the water budget are needed, especially ET. The authors of the two Beaver Creek studies cite increasing ET as the mechanistic cause of declining yields but have no data to support this conclusion. Furthermore, the efficacy of maintenance treatments, usually prescribed burns, for restoring water yield increases has not been evaluated. It is critical to quantify the effects of treatment in the early years of forest restoration in order to inform 4FRI adaptive-management decisions across the landscape.

Our study seeks to test the following five hypotheses:

1. After restoration treatments, runoff will increase and then decline to pretreatment levels within 5-10 years. Groundwater recharge will increase proportionally to runoff.

2. Increases in runoff and recharge will result from maintenance treatments but will be lower than those observed after initial restoration.

3. ET will be reduced by restoration treatments but will recover, mainly because of increases in understory ET.

4. Restoration will increase snowpack, leading to higher spring soil moisture levels.

5. Restoration will not significantly affect sediment yield.

\section{Study Area}

To quantify hydrologic responses to restoration treatments at the watershed scale, 12 watersheds -9 treated and 3 control - were selected within the 4FRI project area, allowing for 3 replicates of the treatment intensities (low, medium, and high) as well as the controls. The watersheds range in size from 153 to 555 hectares (ha) with an average of 323 ha. They are located within two hydrologic unit code level 5 (10 digit code) watersheds (Seaber and others, 1987): Sycamore Creek in the Verde River Basin and Walnut Creek (which includes the Flagstaff municipal Lake Mary watershed) in the Little Colorado River Basin (fig. 1, table 1). Baseflow does not occur in any of the watersheds, except for the Sycamore Creek control (MS-1), which has a spring within the watershed. A streamflow gauge or pressure transducer will be used to measure and control for flow from the spring. Watersheds have consistent geologic parent material and are covered by contiguous ponderosa pine forest. The consistency of vegetation characteristics among catchments will be determined when our initial surveys are performed. Changes in surface water and groundwater storage are assumed to be negligible at the annual scale in these small headwater catchments.

Untreated controls would be ideal, but because of the U.S. Forest Service's concern about wildfire risk, the minimal treatment in the initial 4FRI plan is "burn only" $(<10$ percent basal area change). These minimally treated watersheds will serve as proxy control basins. On the basis of previous research, the minimally treated watersheds would not be expected to significantly affect water balance because controlled burning causes only slight tree mortality in mature forest, and less than a 30-percent decrease in ponderosa pine basal area has not resulted in significant changes in water yield (Baker, 1986; Sackett and others, 1996). Along with pretreatment data from all basins, this plan should provide an adequate control.

For this study, researchers will not be prescribing treatment types but will work within the context of the treatments proposed by the U.S. Forest Service for the 4FRI. Therefore, this study is observational rather than experimental. Because this study tests treatment types that will be applied across $\sim 1$ million hectares (ha) of forest, utilizing the alreadyselected treatment types is a realistic approach that will provide results to inform adaptive forest management that must incorporate multidisciplinary resource objectives.

\section{Determination of Treatment Effect and Study Duration}

In the paired watershed approach, runoff is observed during a pretreatment calibration period. A linear regression model is developed from the calibration-period data that predicts annual runoff in the treatment basin based on runoff in the control basin. After treatment, the effect of the treatment is determined as the difference between runoff measured in the treated basin and that predicted by the regression model using measurements in the 
control basin. According to the algorithm of Kovner and Evans (1954), recommended for use in the Environmental Protection Agency's guidelines for the design of paired watershed studies (Clausen and Spooner, 1993), the length of the measurement periods needed pretreatment and posttreatment to provide statistically significant results can be determined if an expected change in the mean is known. The minimum detectable change in the mean, $d$, for $n_{1}$ and $n_{2}$ years of pretreatment and posttreatment observation, respectively, is given by

$$
d^{2}=s_{x y}^{2} \frac{n_{1}+n_{2}}{n_{1} n_{2}} F\left(1+\frac{F}{n_{1}+n_{2}-2}\right)
$$

where $s_{x y}^{2}$ is the estimated variance of the residuals of the regression equation and $F$ is the $F$ statistic at the desired significance level (usually 0.95 ) with degrees of freedom 1 and $n_{1}+n_{2}-3$.

Determining the value of $s_{x y}^{2}$ requires calibration-period data to establish a regression equation, so observation times cannot be determined until several years after data collection has begun. To estimate a timeframe for the proposed study, we analyzed historical runoff data from the Beaver Creek Experimental Watershed, which has climate and vegetation characteristics similar to that of the proposed study sites. A similar dataset is not available for the other variables of interest in this study. However, we expect the interannual variation,
Table 1. Paired watershed IDs, locations, elevations, soil types, and proposed treatment intensities.

[Soil hydrologic groups use the USDA Natural Resource Conservation Service's system based on soil water transmissivity: A $(>0.76 \mathrm{~cm} / \mathrm{h}), \mathrm{B}$ $(0.38-0.76 \mathrm{~cm} / \mathrm{h}), \mathrm{C}(0.13-0.38 \mathrm{~cm} / \mathrm{h})$, and $\mathrm{D}(<0.13 \mathrm{~cm} / \mathrm{h})$. ha, hectare; $\mathrm{m}$, meters; \%, percent; ft, feet]

\begin{tabular}{|c|c|c|c|c|c|c|}
\hline \multirow[b]{2}{*}{ ID } & \multirow[b]{2}{*}{$\begin{array}{c}\text { Area } \\
\text { (ha) }\end{array}$} & \multirow[b]{2}{*}{$\begin{array}{c}\text { Elevation } \\
\text { (m) }\end{array}$} & \multirow[b]{2}{*}{$\begin{array}{l}\text { Dominant } \\
\text { hydrologic } \\
\text { soil groups }\end{array}$} & \multirow[b]{2}{*}{$\begin{array}{l}\text { Treatment } \\
\text { intensity }\end{array}$} & \multicolumn{2}{|c|}{ Basal area } \\
\hline & & & & & $\begin{array}{l}\text { Reduction } \\
(\%)\end{array}$ & $\begin{array}{c}\begin{array}{c}\text { Final } \\
\left(\mathrm{ft}^{2}\right) \\
\text { acre })\end{array} \\
\end{array}$ \\
\hline \multicolumn{7}{|c|}{ Sycamore Creek watershed } \\
\hline MS-1 & 393 & 2,245 & C, D & Control & 24 & 22 \\
\hline MS-2 & 488 & 2,245 & C, D & Medium & 33 & 19 \\
\hline MS-3 & 555 & 2,260 & C, D & High & 28 & 16 \\
\hline MS-4 & 339 & 2,374 & $\mathrm{C}$ & Low & 27 & 18 \\
\hline LS-1 & 342 & 2,080 & C, D & Control & 26 & 23 \\
\hline LS-2 & 153 & 1,996 & C, D & Medium & 34 & 16 \\
\hline \multicolumn{7}{|c|}{ Lake Mary watershed } \\
\hline LM-1 & 202 & 2,242 & $\mathrm{~B}, \mathrm{C}$ & Control & 17 & 11 \\
\hline LM-2 & 453 & 2,342 & $\mathrm{~B}, \mathrm{C}$ & Low & 27 & 24 \\
\hline LM-3U & 204 & 2,237 & $\mathrm{~B}, \mathrm{C}$ & Low & 28 & 20 \\
\hline LM-3L & 184 & 2,191 & $\mathrm{~B}, \mathrm{C}$ & High & 47 & 12 \\
\hline LM-4 & 235 & 2,209 & $\mathrm{~B}, \mathrm{C}$ & High & 44 & 16 \\
\hline LM-5 & 323 & 2,206 & $\mathrm{~B}, \mathrm{C}$ & Medium & 49 & 16 \\
\hline
\end{tabular}

Figure 1. Central Arizona, showing locations of watersheds designated for study of effects of forest management (colored patches).

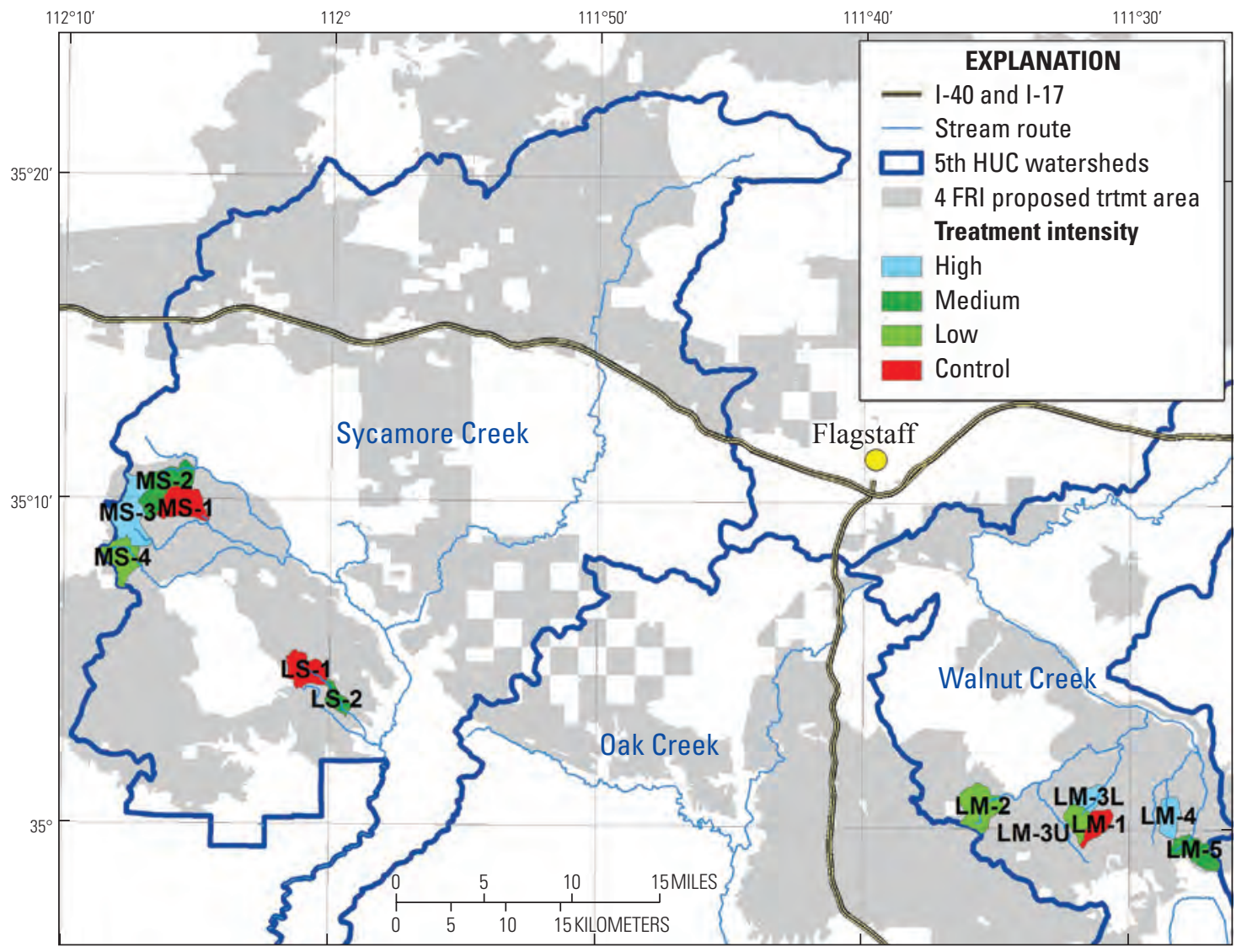


and thus the calibration-period length, to be similar for all hydrologic variables. The improvement in estimating the accuracy as the length of the calibration period increases is plotted in figure 2. On the basis of this estimate, we plan to calculate the necessary calibration and treatment lengths 8 years after data collection begins. We estimate that the total length of the calibration period will be $8-10$ years. The initial period before maintenance treatment will be $6-8$ years, and the watersheds will be monitored for an additional $7-10$ years after maintenance treatments, approximating the timeframe needed to detect a change in runoff of 2.5 centimeters $(\mathrm{cm})$, the minimum change observed in the year immediately after treatment across all of the Beaver Creek treatments conducted in ponderosa pine forests (Baker, 1986). These estimated lengths are based on ideal values for statistical analysis. We will also consider the practical needs of the involved management and funding agencies in scheduling treatments.

\section{Proposed Study Methods}

In this study, we expand on the conventional paired watershed study to evaluate the full water balance within watersheds. After the end of each water year (October 1September 30), data will be summarized, and the annual water balance will be determined. Point-based measurements will be conducted at sites that are representative of each watershed in terms of pretreatment structure and treatment intensity.

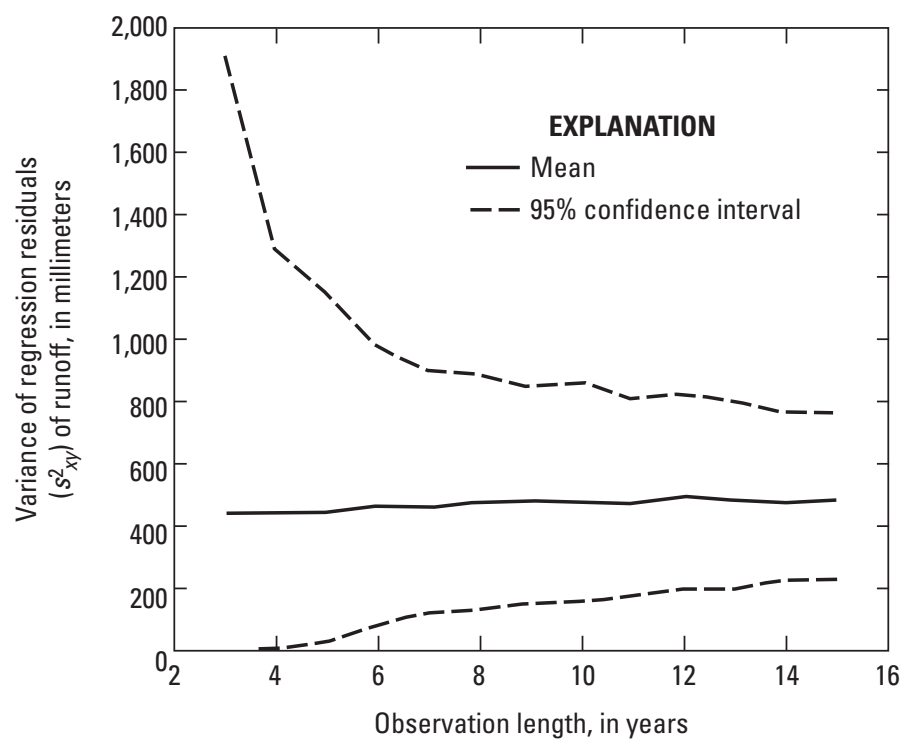

Figure 2. Estimated variance of regression residuals $\left(s_{x y}^{2}\right)$ of runoff versus length of calibration period. Mean (solid line) and bootstrapped 95-percent-confidence intervals (dashed lines) are based on 1,000 simulations for estimating variance of regression residual of regression relationship derived from calibration period data. Data from sites 8 and 13 of the Beaver Creek Experimental Watershed.

\section{Biophysical Monitoring}

To evaluate pretreatment and posttreatment forest conditions that may affect hydrologic-response variables, overstory and understory vegetation will be measured to determine the effect of treatment and to monitor recovery. The biophysical environment will be characterized before and after treatment, largely through monitoring conducted by the U.S. Forest Service but also through biologic surveys completed by the Ecological Restoration Institute (ERI) at Northern Arizona University. Understory vegetation will be monitored by using field plots, based on a sampling design typically used by ERI (Stoddard and others, 2011; McGlone and others, 2012).

Overstory measurements in plots will quantify percentage of tree-canopy cover, tree density, and leaf-area index and determine the distributions of tree heights, ages, species, crown base heights, and canopy volumes. The previous impacts of fire will be estimated as percentage of crown scorch and percentage of bole char. From the overstory measurements, basal area, crown bulk density, and canopy fuel load will be derived. Understory measurements will include frequency and cover of species; tree regeneration by species; shrub density, species distribution, and size-class distribution; and fractional substrate cover. Finally, the surface fuel loading by size class and forest-floor depth will be measured to quantify surface fuels.

\section{Precipitation and Weather}

Each watershed will have one research-grade meteorological station located in the upper part of the watershed, with all-season precipitation gauges placed at the meteorological station site and in the lower watershed at or near the watershed outlet. The weather stations will measure the following parameters at 15-minute intervals: precipitation (rain and snow depth), windspeed and wind direction, solar-radiation flux, temperature, relative humidity, and barometric pressure.

\section{Snow}

Snowmelt from high-elevation forested watersheds is a major source of runoff for most rivers in the southwestern United States (Gottfried and others, 2003), and so measurements of snow-water equivalent (SWE) are required. Snow depth and SWE will be measured in each watershed by using two snow courses, a set transect along which snow depth and SWE are measured at weekly to monthly intervals, and one snow pillow, an automated system that measures and logs SWE.

Snow-course transects will be oriented in straight lines perpendicular to the slope and, if possible, on slopes with a northern aspect. At evenly spaced data-collection points, snow depth and SWE will be measured with a Mount Rose-type sampler. Snow courses, which capture spatial variations in snowpack, will be surveyed monthly. To characterize temporal 
variations, one snow pillow will be installed in each watershed near the snow course and the weather station to measure snow depth and SWE hourly for December through April.

\section{Soil Water Storage}

Soil water content, or soil moisture, is a fundamental determinant of many ecologic processes, particularly in semiarid ecosystems (Zou and others, 2008). Traditional soil moisture sensors, such as time domain reflectometry (TDR) sensors, are generally inexpensive to purchase but can require high labor costs for installation, maintenance, data downloads, and interpolation of data from a few points to broader areas. The recently developed COsmic-ray Soil Moisture Observing System (COSMOS) probe detects cosmic-ray neutrons that are an ever-present component of the land-surface radiation environment and have an intensity that is inversely correlated with water in any form (Desilets and others, 2009), although subsurface and surface contributions are distinguishable. The probe is capable of measuring average soil water content over a circular footprint of 34 hectares (ha) and depths of as much as $50 \mathrm{~cm}$ (Zreda and others, 2012), and so it can characterize soil water content across heterogeneous areas.

One COSMOS probe will be placed in each watershed as resources allow. Each probe will be placed such that the entire measurement footprint is contained within the central part of the watershed. Measurements will be recorded every few seconds and transmitted several times per day. An array of three sets of TDR sensors will be placed in each watershed, within the footprint of COSMOS data collection where applicable. The TDR sensors will be placed at multiple depths in shallow $(<40 \mathrm{~cm})$ and deep $(>40 \mathrm{~cm})$ rooting zones and will measure soil moisture at 15 -minute intervals. The two methods will serve as a check on each other, but the TDR probes will also characterize soil water storage in the deep rooting zone of mature ponderosa trees, a depth to which the COSMOS probe does not consistently reach. A pilot study is currently underway using a portable TDR instrument to characterize the spatial heterogeneity of soil moisture in ponderosa pine forests. The findings from this study will inform the placement of TDR probes to provide the best possible representation of the spatial variation in soil water storage.

\section{Evapotranspiration}

ET will be monitored by using a combination of measurements, including sap flux, soil water content, and eddy-covariance (EC) flux. EC flux, in which fast fluctuations of vertical windspeed are correlated with fast fluctuations in atmospheric water-vapor density, is the most direct method of measuring ET at the ecosystem scale. Owing to high costs relative to other measurements, it is feasible to install EC towers in only a maximum of six watersheds. The preliminary selection of the six watersheds includes two controls (MS1, LM-1, fig. 1), two medium-intensity treatments (MS-2,
LM-5), and two high-intensity treatments (MS-3, LM-4). Overstory and understory transpiration will be measured at all watersheds and scaled up to ecosystem ET, with EC measurements used for validation.

Overstory transpiration will be measured by using Graniertype heat-dissipation sap-flux sensors ( $\mathrm{Lu}$ and others, 2004), based on the detection of convective heat transport with the sap stream. Two sensors are inserted into the sapwood $\sim 4 \mathrm{~cm}$ apart vertically. The upper sensor is heated with constant power, and the sap-flow velocity is calculated from the temperature difference between the two needles. Sap-flux sensors will be installed in trees representing all diameter classes, and information on the density and size distribution of overstory trees (see subsection above entitled "Biophysical Monitoring") will be used to determine ecosystem-level overstory transpiration flux. Following Simonin and others (2007), the sum of understory transpiration and soil evaporation will be estimated as the rate of change of shallow $(<40 \mathrm{~cm})$ soil moisture during rain-free periods when soil moisture is below field capacity (that is, when gravity-driven drainage is negligible).

\section{Groundwater Recharge}

Groundwater recharge will be measured by using chloride mass balance, a common approach in arid and semiarid regions (Allison and others, 1994; Guan and others, 2010). Atmospheric input of chloride in precipitation, as well as dry deposition, is concentrated in the soil water by ET, which does not remove chloride. By measuring chloride concentration in precipitation, runoff, and soil water over a depth profile, the rate of deep drainage below the root zone can be determined. Although determination of water transport below the root zone is complicated by the regional geology, we assume that water will either infiltrate into aquifers or discharge as baseflow at downstream sites, thus contributing to regional water resources. A pilot study is currently underway to determine the frequency of sampling and the number of sample points needed to accurately characterize groundwater recharge in ponderosa pine forests.

\section{Streamflow}

Parshall flumes will be used to measure streamflow at the outlet of each watershed. Flumes of a size that provide good precision for low-flow data will be fitted into steelplate weirs designed to traverse the width of the stream. Each flume will be equipped with a built-in stilling well with a self-contained pressure transducer to measure depth. For higher flows that overtop the flume, crest-stage gauges will be installed.

The installation of Parshall flumes requires extensive planning, and permitting is likely to delay the start of calibration-period data collection. For initial data collection, a new method utilizing time-lapse cameras, which we refer to as "flowtography," will be used to estimate streamflow. 
The channel cross section and profile are surveyed by using a laser level and rod, bankfull width is flagged, and channel roughness is estimated. A calibrated T-post with reflective markings at 6-inch intervals is driven into the channel at the deepest point on the cross section. A time-lapse wildlifetracking camera is mounted in a tree and focused on the T-post, and photographs are taken day and night at 15-minute intervals (fig. 3). Water height is determined visually from the photographs and used to calculate streamflow from Manning's equation:

$$
V=\frac{k}{n} R_{h}^{2 / 3} S^{1 / 2}
$$

where $V$ is the cross-sectional average velocity, $k$ is a

conversion factor, $n$ is the unitless Manning coefficient for surface roughness, $R_{h}$ is the hydraulic radius of the channel, and $S$ is the slope of the water surface. After flumes are installed, the cameras and T-post gauges will be left in service for a period of at least 1 year to determine how closely this method estimates streamflow.

\section{Water Quality}

Because forested watersheds provide a considerable percentage of drinking water to cities in Arizona, there is concern about the potential positive or negative effects on water quality of forest restoration treatments. Event-driven water-quality samples will be collected with an ISCO automatic sampler prompted by the streamflow gauge's pressure transducer. Samples will be collected hourly until the flow event ends or all the autosampler bottles are full. The main parameters of concern will be suspended-sediment concentration (SSC; to gauge sediment discharge, see next subsection), total organic carbon content, and chloride concentration (for use in the chloride mass-balance calculation), but other basic water-quality parameters may also be analyzed ( $\mathrm{pH}$, conductivity, salinity, isotopes, and so on).

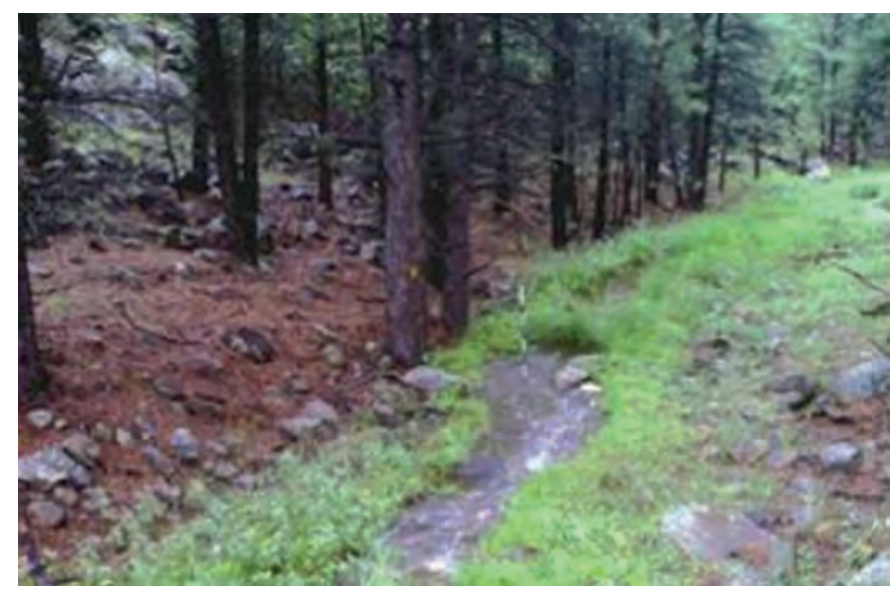

Figure 3. Typical photograph from a time-lapse "flowtography" camera aimed at a calibrated T-post to estimate water depth. Photo provided by Salt River Project.

\section{Sediment Yield}

Soil erosion and sediment yield in forest systems have significant economic and environmental effects (Ward and Baker, 1984). In this study, silt fences will be used to determine natural and management-induced hillslope-erosion rates in the paired watersheds (Robichaud and Brown, 2002). A silt fence is a synthetic geotextile fabric with small (0.30.8 millimeter) openings that pass water but not sediment; it is anchored in place by wiring it to wooden or metal posts. A minimum of 4 silt fences will be installed in each watershed.

For estimating SSC in streams, turbidity is generally a much better predictor than water discharge (Lewis, 1996). With frequent calibration, the relation of turbidity to SSC can be used to estimate suspended-sediment loads efficiently. At each streamflow gauge, an in situ turbidimeter will be installed to measure and record turbidity at 15-minute intervals and compared with laboratory measurements of total suspended solids (TSS) in water collected by the ISCO autosampler to establish a turbidity-SSC relationship. Annual sediment yield will be calculated for comparison between catchments.

\section{Data Analysis and Modeling}

Our proposed analyses fall into two categories. (1) Hypothesis testing seeks to determine whether forest restoration treatment has a statistically significant effect on the parameters of interest that are being measured directly in the watersheds: runoff, ET, SWE, soil moisture, water quality, and groundwater recharge. (2) Model development and validation uses the collected data to test and improve the ability of hydrologic models to represent the effects of forest restoration. These analytical methods are preliminary, and more specific methods will be developed adaptively during the early stages of data collection.

\section{Hypothesis Testing}

A paired watershed study with both calibration and treatment observations is an example of a before/after, controlimpact paired-series (BACIPS) experimental design. The effect of treatment that is quantified by the linear regression approach described in the subsection entitled "Determination of Treatment Effect and Study Duration" can be tested for statistical significance by using standard hypothesis-testing methods. If the assumptions are met, the greatest statistical power for determining whether the effect of treatment is statistically significant in a BACIPS study is given by analysis of variance (ANOVA), with the difference between measurements in paired treatments as the dependent variable and treatment type and observation period (pretreatment or posttreatment) as the independent variables (Smith, 2006). In 
the case of paired watersheds, the absolute difference between the treatment and control measurement of most variables of interest will be influenced by climate (Baker, 1986). Therefore, we will use analysis of covariance (ANCOVA), with annual or winter precipitation as a covariate.

\section{Model Development and Testing}

Paired watershed experiments are commonly criticized for having little or no replication, owing to physical constraints. Their value lies largely in their utility for calibrating and testing hydrologic models and not in statistical inference (DeFries and Eshleman, 2004). This study will be especially useful for modeling applications because it measures several components of the water budget, unlike previous paired watershed studies that measured only precipitation and runoff. These additional measurements, including ET, groundwater recharge, SWE, and soil moisture, will enable verification of the internal components of process-based hydrologic models. Modeling efforts associated with the paired watershed project will be framed by the identification and parametrization of a basin-scale water balance model. Several existing models will be tested for their ability to accurately represent the effects of restoration on the water balance, including the U.S. Forest Service's Forest Vegetation Simulator-Water Resources Evaluation of Non-point Silvicultural Sources (FVS-WRENSS) and models from academia, such as the topographic model (TOPMODEL) and the triangulatedirregular-network (TIN)- based Real-time Integrated Basin Simulator (tRIBS). The goal of this future modeling work will be to extrapolate the results of the paired-watershed study to larger catchments, such as the Salt and Verde River watersheds, where forest restoration could impact the water resources of major metropolitan areas.

\section{Acknowledgments}

This study design was developed with the help of W. Wallace Covington and David W. Huffman of the Ecological Restoration Institute. The report was reviewed by Mark Hubbel and Tim Skarupa of the Salt River Project, Dan Neary and Bill Elliott of the U.S. Forest Service's Rocky Mountain Research Station, Pete Wolgemuth of the U.S. Forest Service's Pacific Southwest Research Station, Roy Jemison of U.S. Forest Service Region 3, Dino De Simone of the U.S. Department of Agriculture's Natural Resources Conservation Service, and Wonsook Ha of the Northern Arizona University School of Earth Science and Environmental Sustainability. It was prepared in partial fulfillment of Salt River Project Contract 12.0356 .

\section{References Cited}

Allen, C.D., Savage, M., Falk, D.A., Suckling, K.F., Swetnam, T.W., Schulke, T., Stacey, P.B., Morgan, P., Hoffman, M., and Klingel, J.T., 2002, Ecological restoration of southwestern ponderosa pine ecosystems - a broad perspective: Ecological Applications, v. 12, no. 5, p. 1418-1433, at http://dx.doi. org/10.1890/1051-0761(2002)012\%5B1418:EROSPP\% 5D2.0.CO;2.

Allison, G.B., Gee, G.W., and Tyler, S.W., 1994, Vadose-zone techniques for estimating groundwater recharge in arid and semi-arid regions: Soil Science Society of America Journal, v. 58, no. 1, p. 6-14, at http://dx.doi.org/10.2136/ sssaj1994.03615995005800010002x.

Andréassian, V., 2004, Waters and forests-from historical controversy to scientific debate: Journal of Hydrology, v. 291, no. 1-2, p. 1-27, at http://dx.doi.org/10.1016/j. jhydrol.2003.12.015.

Baker, M.B., Jr., 1986, Effects of ponderosa pine treatments on water yield in Arizona: Water Resources Research, v. 22, no. 1, p. 67-73, at http://dx.doi.org/10.1029/ WR022i001p00067.

Baker, M.B., Jr., 1999, History of watershed research in the central Arizona highlands: Fort Collins, Colo., U.S. Forest Service, Rocky Mountain Research Station General Technical Report RMRS-GTR-29, 56 p., accessed on April 29, 2015, at http://www.fs.fed.us/rm/ pubs/rmrs_gtr029.pdf.

Breshears, D.D., Nyhan, J.W., Heil, C.E., and Wilcox, B.P., 1998, Effects of woody plants on microclimate in a semiarid woodland - soil temperature and evaporation in canopy and intercanopy patches: International Journal of Plant Sciences, v. 159, no. 6, p. 1010-1017, at http:// dx.doi.org/10.1086/314083.

Brown, H.E., Baker, M.B., Jr., Rogers, J.J., Clary, W.P., Kovner, J.L., Larson, F.R., Avery, C.C., and Campbell, R.E., 1974, Opportunities for increasing water yields and other multiple use values on ponderosa pine forest lands: Fort Collins, Colo., U.S. Forest Service, Rocky Mountain Forest and Range Experiment Station Research Paper RM-129, 36 p., accessed on April 29, 2015, at http://www.biodiversitylibrary.org/item/177700 - page/42/mode/1up.

Clausen, J.C., and Spooner, J., 1993, Paired watershed study design: Washington, D.C., Environmental Protection Agency, Office of Wetlands, Oceans, and Watersheds Report, EPA 841-F-93-009, 8 p., accessed on April 29, 2015, at http://www.in.gov/idem/nps/files/iwpg_paired watersheds.pdf. 
Covington, W.W., Fule, P.Z., Moore, M.M., Hart, S.C., Kolb, T.E., Mast, J.N., Sackett, S.S., and Wagner, M.R., 1997, Restoring ecosystem health in ponderosa pine forests of the southwest: Journal of Forestry, v. 95, no. 4, p. 23-29, accessed on April 29, 2015, at http://www.fs.fed.us/psw/ publications/4403/Restoring.pdf.

Covington, W.W., and Moore, M.M., 1994, Southwestern ponderosa forest structure-changes since Euro-American settlement: Journal of Forestry, v. 92, no. 1, p. 39-47, accessed on April 29, 2015, at http://library.eri.nau.edu/gsdl/ collect/erilibra/index/assoc/HASH01c1.dir/doc.pdf.

DeFries, R., and Eshleman, K.N., 2004, Land-use change and hydrologic processes - a major focus for the future: Hydrological Processes, v. 18, no. 11, p. 2183-2186, at http://dx.doi.org/10.1002/hyp.5584.

Desilets, D., Mascarenhas, N., Marleau, P., and Brennen, J.S., 2009, Land-surface hydrology with a directional neutron detector: Albuquerque, N.Mex., Sandia National Laboratories Report SAND2009-6321, 21 p., accessed on April 30, 2015, at http://prod.sandia.gov/techlib/accesscontrol.cgi/2009/096321.pdf.

Dore, S., Montes-Helu, M., Hart, S.C., Hungate, B.A., Koch, G., Moon, J.B., Finkral, A.J., and Kolb, T.E., 2012, Recovery of ponderosa pine ecosystem carbon and water fluxes from thinning and stand-replacing fire: Global Change Biology, v. 18 , no. 10, p. 3171-3185, at http:// dx.doi.org/10.1111/j.1365-2486.2012.02775.x.

Gottfried, G.J., and DeBano, L.F., 1990, Streamflow and water quality responses to pre-harvest prescribed burning in an undisturbed ponderosa pine watershed, in Krammes, J.S., ed., Effects of Fire Management of Southwestern Natural Resources Symposium, Tucson, Ariz., 1988 Proceedings: U.S. Forest Service, Rocky Mountain Forest and Range Experiment Station General Technical Report RM-191, p. 222-228, accessed on April 30, 2015, at http://www.fs.fed. us/rm/pubs_rm/rm_gtr191.pdf.

Gottfried, G.J., Neary, D.G., and Ffolliott, P.F., 2003, Snowpack-runoff relationships for forested mid-elevation watersheds and a high-elevation watershed in Arizona, in Annual Western Snow Conference, 71st, Scottsdale, Ariz., 2003, Proceedings, p. 49-58, accessed on April 30th, 2015, at http://www.westernsnowconference.org/node/792.

Guan, H., Love, A.J., Simmons, C.T., Hutson, J., and Ding, Z., 2010, Catchment conceptualisation for examining applicability of chloride mass balance method in an area with historical forest clearance: Hydrology and Earth System Sciences, v. 14, no. 7, p. 1233-1245, at http:// dx.doi.org/10.5194/hess-14-1233-2010.
Gustafson, J.R., Brooks, P.D., Molotch, N.P., and Veatch, W.C., 2010, Estimating snow sublimation using natural chemical and isotopic tracers across a gradient of solar radiation: Water Resources Research, v. 46, no. W12511, at http://dx.doi.org/10.1029/2009WR00906.

Hewlett, J.D., and Pienaar, L., 1973, Design and analysis of the catchment experiment, in White, E.H., ed., Proceedings of a Symposium on Use of Small Watersheds in Determining Effects of Forest Land Use on Water Quality: Lexington, University of Kentucky, May 22-23, p. 88-106.

Kovner, J.L., and Evans, T.C., 1954, A method for determining the minimum duration of watershed experiments: Eos (American Geophysical Union Transactions), v. 35, no. 4, p. 608-612, accessed on May 4, 2015, 2015, at http:// onlinelibrary.wiley.com/doi/10.1029/TR035i004p00608/pdf.

Lewis, Jack, 1996, Turbidity-controlled suspended sediment sampling: Water Resources Research, v. 32, no. 7, p. 2299-2310, accessed October 5, 2015, at http://www.aces. edu/ reuteem/temp/RobertFiles/SuspendedSediment $\% 20$ vs\%20Turbidity.pdf.

Lu, P., Urban, L., and Ping, Z., 2004, Granier's thermal dissipation probe (TDP) method for measuring sap flow in trees - theory and practice: Acta Botanica Sinica, v. 46, no. 6, p. 631-646, accessed on May 4, 2015, at http://www. plantsensors.com/pdf/abs2004.pdf.

McGlone, C.M., Stoddard, M.T., Springer, J.D., Daniels, M.L., Fulé, P.Z., and Covington, W.W., 2012, Nonnative species influence vegetative response to ecological restoration - two forests with divergent restoration outcomes: Forest Ecology and Management, v. 285, p. 195-203, at http://dx.doi. org/10.1016/j.foreco.2012.08.022.

Musselman, K.N., Molotch, N.P., and Brooks, P.D., 2008, Effects of vegetation on snow accumulation and ablation in a mid-latitude sub-alpine forest: Hydrological Processes, v. 22, no. 15 (special issue), p. 2767-2776, at http://dx.doi. org/10.1002/hyp.7050.

Rich, L.R., and Gottfried, G.J., 1976, Water yields resulting from treatments on the Workman Creek experimental watersheds in central Arizona: Water Resources Research, v. 12, no. 5, p. 1053-1060, at http://dx.doi.org/10.1029/ WR012i005p01053.

Robichaud, P.R., and Brown, R.E., 2002, Silt Fences-An economical technique for measuring hillslope soil erosion: Fort Collins, Colo., U.S. Forest Service, Rocky Mountain Research Station General Technical Report RMRS-GTR-94, 29p., accessed on October 5, 2015, at http://www.researchgate.net/ profile/Peter_Robichaud/publication/265287010_Silt_Fences An_Economical_Technique_for_Measuring_Hillslope_Soil_ Erosion/links/54b007780cf28ebe92de3fb5.pdf. 
Seaber, P.R., Kapinos, F.P., and Knapp, G.L., 1987, Hydrologic unit maps: U.S. Geological Survey Water-Supply Paper 2294, 63 p., at http://pubs.usgs.gov/wsp/wsp2294/.

Seibert, J., McDonnell, J.J., and Woodsmith, R.D., 2010, Effects of wildfire on catchment runoff response-a modeling approach to detect changes in snow-dominated forested catchments: Hydrology Research, v. 41, no. 5, p. 378-390, at http://dx.doi.org/10.2166/nh.2010.036.

Simonin, K., Kolb, T.E., Montes-Helu, M., and Koch, G.B., 2007, The influence of thinning on components of stand water balance in a ponderosa pine forest stand during and after extreme drought: Agricultural and Forest Meteorology, v. 143, no. 3-4, p. 266-276, at http://dx.doi.org/10.1016/j. agrformet.2007.01.003.

Smith, E.P., 2006, BACI design-ecological statistics, in El-Shaarawi, A.H., and Piegorsch, W.W., eds., Encyclopedia of environmetrics: Chichester, UK, John Wiley and Sons, v. 1, p. 141-148, at http://dx.doi.org/10.1002/9780470057339. vab001.

Stoddard, M.T., McGlone, C.M., Fulé, P.Z., Laughlin, D.C., and Daniels, M.L., 2011, Native plants dominate understory vegetation following ponderosa pine forest restoration treatments: Western North American Naturalist, v. 71, no. 2, p. 206-214, at http://dx.doi.org/10.3398/064.071.0207.

U.S. Forest Service, 2011, Proposed action for Four-Forest Restoration Initiative, Coconino and Kaibab National Forest, Coconino County, Arizona: Southwestern Region report, 4FRI Team, 91 p., accessed on April 10, 2015, at http:/www.fs.usda.gov/Internet/FSE_DOCUMENTS/ stelprdb5324204.pdf.
U.S. Forest Service, 2013, Draft environmental impact statement for the four-forest restoration initiative, Coconino and Kaibab National Forests, Coconino County, Arizona: Flagstaff, Ariz., Southwestern Region Report MB-R3-0419, 435 p., accessed on May 8, 2015, at http://fs.usda.gov/ Internet/FSE_DOCUMENTS/stelprdb5413745.pdf.

Ward, T.J., and Baker, M.B., Jr., 1984, Sediment from managed pine watershed in northern central Arizona, in Replogle, J.A., and Renard, K.G., eds., Specialty Conference-Water Today and Tomorrow, Flagstaff, Ariz.,1984, Proceedings: American Society of Civil Engineers, Irrigation and Drainage Division, p. 552-558, accessed on May 8, 2015, at http://cedb.asce.org/cgi/WWWdisplay.cgi?41363.

Winstral, A., and Marks, D., 2002, Simulating wind fields and snow redistribution using terrain-based parameters to model snow accumulation and melt over a semi-arid mountain catchment: Hydrological Processes, v. 16, no. 18, (special issue), p. 3583-3603, at http://dx.doi.org/10.1002/hyp.1238.

Zou, C.B., Breshears, D.D., Newman, B.D., Wilcox, B.P., Gard, M., and Rich, P.M., 2008, Soil water dynamics under low- versus high-ponderosa pine tree densityecohydrological functioning and restoration implications: Ecohydrology, v. 1, no. 4, p. 309-315, at http://dx.doi. org/10.1002/eco.17.

Zreda, M., Shuttleworth, J., Zeng, X., and Zweck, C., 2012, COSMOS Cosmic-ray Soil Moisture Observing System: National Science Foundation, Atmospheric and Geospace Sciences Division, accessed May 7, 2015, at http://cosmos. hwr.arizona.edu/. 


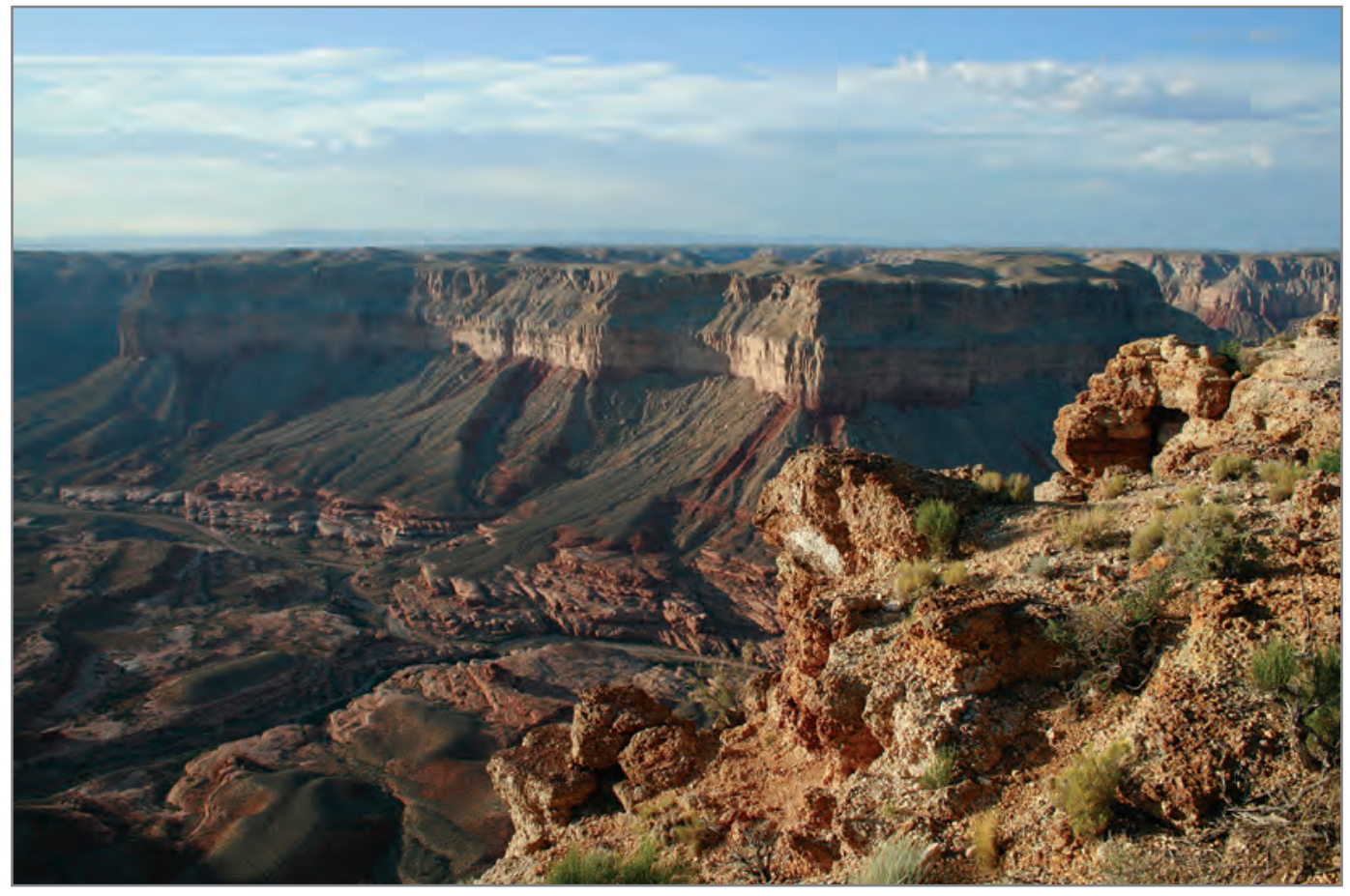

Kanab Basin looking west. Photograph by Robert J. Hart, U.S. Geological Survey. 


\title{
Long-Term Post-Wildfire Correlates with Avian Community Dynamics in Ponderosa Pine Forests
}

\author{
By Jamie S. Sanderlin, ${ }^{1}$ William M. Block, ${ }^{1}$ and Brenda E. Strohmeyer ${ }^{1}$
}

\section{Abstract}

We used a 10-year data set to illustrate the longterm correlates of wildfire on avian species richness in the ponderosa pine (Pinus ponderosa) forests of northern Arizona. This study was conducted in the vicinity of the Horseshoe and Hochderffer Fires, which occurred in 1996, and sampling began 1 year after the fires. Using pointcount data from breeding seasons, we described how avian species richness, local colonization, and local extinction changed over time following the wildfires. We used Bayesian hierarchical models to describe occupancy as a function of burn severity (severe, moderate, or unburned), years since wildfire, and species, while accounting for variables that influenced detection probability, such as species and sampling effort. The avian species from our study followed general patterns predicted from changes in vegetation structure in response to fire based on foraging and nesting requirements. Our results indicated that landscape heterogeneity from a mixture of fire severities and time since fire increased overall species richness across the landscape. Avian species in pine forests evolved with fire. Given that some species demonstrated an affinity to severely burned forests suggests that similar conditions existed historically.

\section{Introduction}

Disturbance plays important roles for the conservation of birds by influencing habitat distribution and landscape heterogeneity. Increasing landscape heterogeneity often leads to increased overall species richness with patches having different species compositions (Brawn and others, 2001; Platt and Connell, 2003). Species richness is a common indicator of management success (for example, Russell and others, 2009). Within pine forests in the southwestern United States fire is a common natural disturbance (Covington and Moore, 1994; Moir and others, 1997), and some avian

${ }^{1}$ U.S. Forest Service Rocky Mountain Research Station species have evolved as fire specialists (Hutto and others, 2008). Historically, fires in these pine forests tended to be low-severity surface fires. Within the past 20 years, however, fire regimes have changed and have become high-severity, stand-replacing events. An increase in the frequency of large, severe wildfires in the southwestern United States can be attributed to increases in fuel loads and continuity as the result of livestock grazing, logging, and fire suppression (Allen and others, 2002; Covington and Moore, 1994; Moore and others, 1999; Swetnam and others, 1999).

Most information about avian response to wildfire is short-term ( $<5$ years) (Saab and Powell, 2005; Saab and others, 2005). As changes in forest structure occur from fire, we would expect some bird species to respond differently depending on time since fire and the fire regime of the area. Foraging method, nest type, and location all influence a species response to fire (Saab and Powell, 2005). In addition to time since fire, fire severity influences bird response to fire (Kotliar and others, 2002; Smucker and others, 2005). Further, relatively little is known about avian response to southwestern fires extending the need to improve management strategies for avian species (Bock and Block, 2005). One of the primary management tools in southwestern ponderosa pine forests is prescribed fire, so we need to understand how birds respond to wildfire at different burn severities and if we can mimic the historical fire regime with the frequency and severity of prescribed fire.

Our objectives were to quantify wildfire correlates with avian community metrics in Northern Arizona following the Hochderffer and Horseshoe Fires of 1996. Specifically, we were interested in relations of fire burn severity and time since wildfire with species occupancy, species richness, and local colonization and local extinction. We used multispecies occupancy models (Dorazio and others, 2006; MacKenzie and others, 2006) to estimate community metrics, while accounting for imperfect detection. Imperfect detection is important to include in analyses, especially with rare or elusive species or when trying to assess change over time. Estimates of community metrics could be biased if species occupy an area but were never detected during a survey or multiple surveys and could lead to biased study conclusions and management actions. 


\section{Methods}

\section{Study Area}

Two wildfires (Horseshoe Fire and Hochderffer Fire) occurred in May and June 1996 in the Flagstaff Ranger District of the Coconino National Forest in north-central Arizona. The region of the fires is shown in figure 1.

The Horseshoe Fire encompassed about 3,500 hectares (ha) and the Hochderffer fire encompassed more than 6,600 ha adjacent to the Horseshoe Fire. The predominant vegetation type was ponderosa pine forest. Other tree species included Gambel oak (Quercus gambelii), piñon pine (Pinus edulis), and alligator (Juniperus deppeana) and one-seeded junipers (J. monosperma). Understory vegetation included buckbrush (Ceanothus fendleri), rabbitbrush (Chrysothamnus nauseosa), Oregon grape (Mahonia repens), and various grasses and forbs.
Burn severity in these areas ranged from high to moderate to low. We used three broad categories of severity (high, moderate, unburned) originally defined by Dwyer and Block (2000) within our analyses. We used the following ranges of the delta normalized burn ratio (dNBR) generated from a comparison of Landsat Thematic Mapper (TM) imagery recorded before and after wildfire (Eidenshink and others, 2007; also see http://www.mtbs.gov/) to define the burn severity categories for each transect. Raw dNBR values were compiled at a $30 \times 30$ meter $(\mathrm{m})$ resolution, and a mean $\mathrm{dNBR}$ was calculated for a 100-m-radius neighborhood centered on the point count station. Our high severity category represented average dNBR of all points per transect $\geq 150$, moderate severity was $<150$ and $\geq 65$, and unburned was $<65$. We used unburned areas for contrasts because pre-wildfire data were unavailable. Unburned areas were similar to burned areas with respect to pre-burn stand structure and species composition but may have deviated from pre-settlement ponderosa pine forest conditions described by Covington and others (1997).

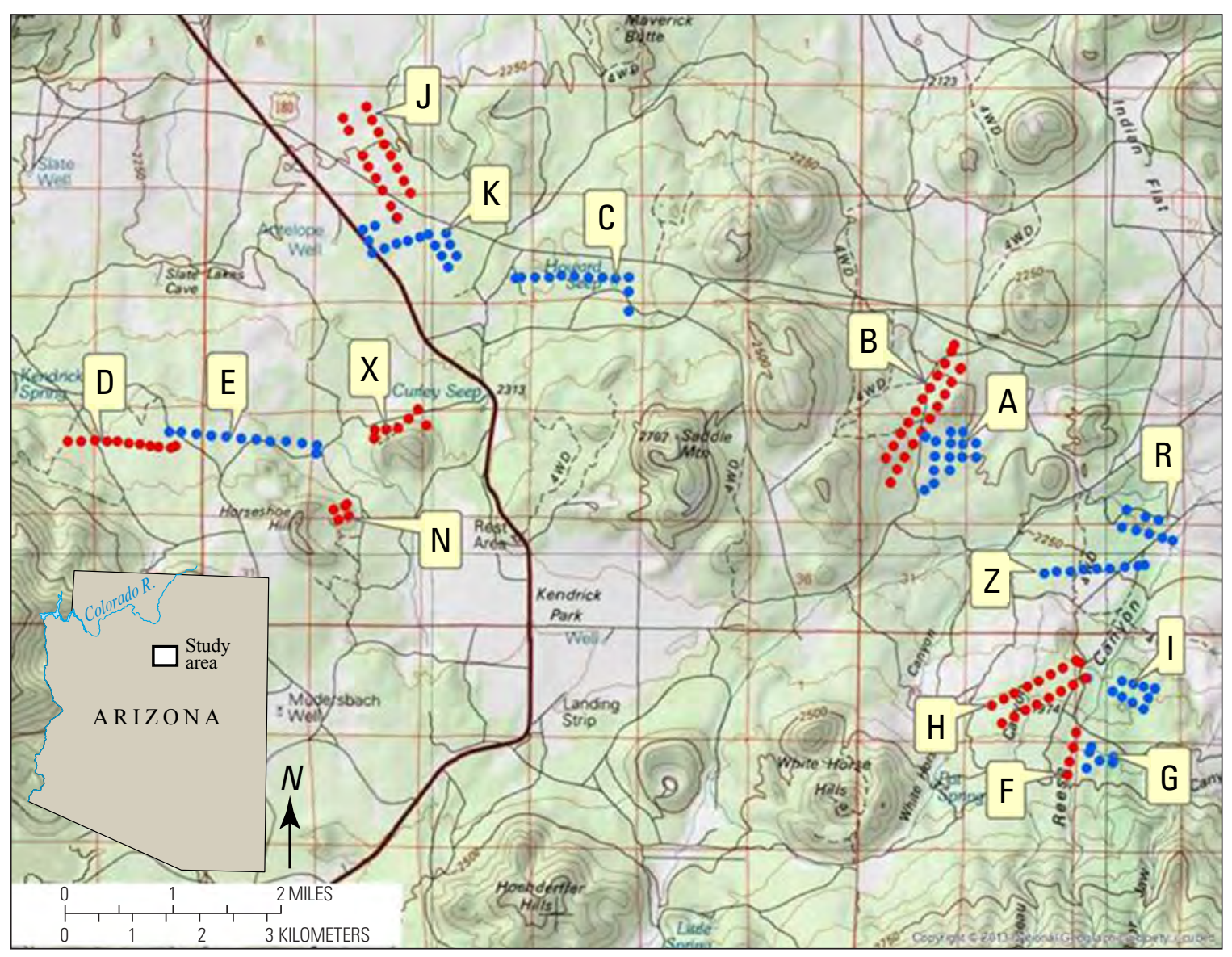

Figure 1. Map showing the avian community study area after the Hochderffer and Horseshoe wildfires that occurred in 1996 in northern Arizona. All 15 avian transects are labeled on the topographic map using different colors to easily distinguish the different transects: blue circles (transects $A, C, E, G, I, K, R, Z$ ), red circles (transects B, D, F, H, J, N, X). (Topographic map from Esri ArcGIS Resources online, copyright 2013 National Geographic Society and ri-cubed.). 


\section{Field}

We sampled birds starting 1 year after the fires using the variable-radius point-count method (Reynolds and others, 1980). Sampling occurred during the breeding season over a period of 10 years (primary periods), where each season had as much as three secondary periods (visits). Each transect route consisted of an average of 10 points (range 3-20) spaced at $200 \mathrm{~m}$ intervals. The 15 transect lines were categorized as high severity ( 7 transects with 49 points total), moderate severity (4 transects with 50 points total), and unburned (4 transects with 50 points total). We sampled each point three times during the summer breeding season to sample variation in bird distribution and detectability. Counts began within 30 minutes of sunrise and were completed no later than 4 hours after sunrise to sample points during periods of high bird activity. Observers remained still for 2 minutes after reaching a point to allow birds to resume normal activity patterns after disturbance. The actual point count lasted 8 minutes. The observer recorded weather, windspeed, and temperature in addition to species, age, and sex of all birds detected, mode of detection (audio or visual), and estimated horizontal distance to the bird.

\section{Analytical}

We used Bayesian hierarchical models (Gelman and others, 2004) to model detection and occupancy (MacKenzie and others, 2006; Royle and Dorazio, 2008, p. 380-399) and to estimate species richness $N$. We assumed occupancy states of species could change with local extinction and colonization between years, but not during each summer season of each year. We condensed data across points within each transect to increase species detections per year and to reduce model complexity. We used a three-dimensional data matrix $\mathbf{y}$, where element $y_{i j t}$ was a sum of binary indicators for species detection of species $i(i=1, \ldots, N)$ at transect $j(j=1, \ldots, 15)$ during primary sampling occasion year $t(t=1, \ldots, 10)$, rather than the binary indicators of species detection typically used in single-species or multispecies occupancy models. When binary indicator of species detection $x_{i j t}=1$, we detected species $i$ at transect $j$ during primary sampling occasion year $t$. We used the sum of all binary species $i$ detections over all secondary sampling occasions at each transect, where $v_{j i t}=\sum_{s=1}^{3} x_{j / j}$ and $\nu_{j i t}=\{0,1,2,3\}$. We used species, time since wildfire, and burn severity to model probability of occupancy, and we used species and effort to model detection probability. For numerical reasons, we use standardized covariates of time since wildfire and effort. We defined effort as number of points in each transect (table 1).

\section{Model}

Because we were interested in the whole avian community, not just the species we observed $\left(n_{o b s}\right)$, we used Bayesian hierarchical models with unknown species richness
Table 1. Number of bird-count points sampled per transect at different burn severities (high, moderate, unburned) after the 1996 Hochderffer and Horseshoe wildfires that occurred in northern Arizona.

\begin{tabular}{clc}
\hline Transect & Burn severity & $\begin{array}{c}\text { Number of point- } \\
\text { count stations }\end{array}$ \\
\hline A & High & 14 \\
B & Moderate & 20 \\
C & High & 10 \\
D & High & 10 \\
E & Unburned & 10 \\
F & High & 3 \\
G & High & 4 \\
H & Moderate & 15 \\
I & High & 9 \\
J & Unburned & 15 \\
K & Unburned & 15 \\
N & High & 4 \\
R & Moderate & 7 \\
X & High & 5 \\
Z & Moderate & 8 \\
N & High & 4 \\
\hline
\end{tabular}

${ }^{1}$ Transect D was classified as unburned for the first 3 years after wildfire. The Pumpkin Fire went through this area in 2000, so for years 4 through 10 it was classified as high burn severity.

(Royle and Dorazio, 2008, p. 384-387). We defined $w_{i}$ as a latent Bernoulli random variable, with probability $\Omega$, indicating whether species $i$ from the supercommunity was available for sampling during all primary sampling seasons:

$$
\left[w_{i} \mid \Omega\right] \sim \operatorname{Bern}(\Omega) .
$$

This assumed all of our avian community species were part of the same supercommunity, or regional species pool. To model community change, we assumed a Markovian process described the current occupancy state, whereby probability of occupancy at time $t$ was partially dependent on the probability of occupancy at time $t-1$. We modeled the probability of Bernoulli latent variable $z_{i j t}$ for occupancy given probability of occupancy $\psi_{i j t}$ and $w_{i}$ as:

$$
\left[z_{i j t} \mid \Psi_{i j t}, w_{i}\right] \sim \operatorname{Bern}\left(\Psi_{i j t} w_{i}\right),
$$

where probability of occupancy $\psi_{i j t}$ was a function of covariates (indicator of moderate burn severity [mburn], indicator of high burn severity [hburn], time since wildfire [time], time since wildfire squared $\left[\right.$ time $\left.^{2}\right]$ ) and the previous occupancy state with $z_{i j 0} \sim \operatorname{Bern}\left(a_{i 1(0)}\right)$ : 


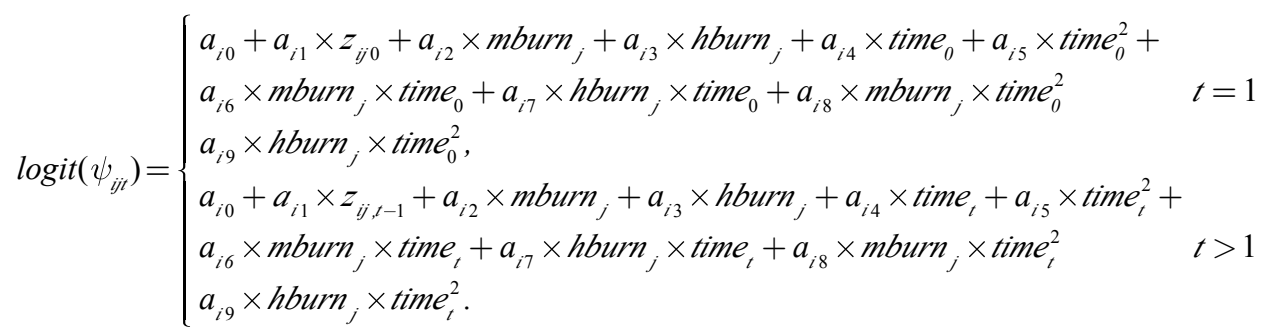

Value $a_{i 1}$ describes a species-specific normal random effect for local probability of survival. These terms also describe species-specific normal random effects: $a_{i 0}$ (intercept), $a_{i 2}$ (moderate burn severity), $a_{i 3}$ (high burn severity), $a_{i 4}$ (time since wildfire), $a_{i 5}$ (time since wildfire squared), $a_{i 6}$ (interaction between time since wildfire and moderate burn severity), $a_{i 7}$ (interaction between time since wildfire and high burn severity), $a_{i 8}$ (interaction between time since wildfire squared and moderate burn severity), and $a_{i 9}$ (interaction between time since wildfire squared and high burn severity). We included quadratic effects of time since wildfire to capture nonlinear responses of species. Occupancy parameter estimates for each species were random variables governed by community-level parameters.

We modeled the probability of observation of species $i$ at transect $j$ during primary period $t, y_{i j t}$, given secondary periods $K$, probability of detection $p_{i j}$, and occupancy latent variable $z_{i j t}$ using a binomial distribution with $K$ trials and probability of success $p_{i j} \times z_{i j t}$ :

$$
\left[y_{i j t} \mid p_{i j}, z_{i j t}\right] \sim \operatorname{Bin}\left(K, p_{i j} \times z_{i j t}\right) .
$$

We used species and sampling effort (eff) as covariates to model probability of detection $p$ :

$$
\operatorname{logit}\left(p_{i j}\right)=b_{i 0}+b_{1} \times e f f_{j} .
$$

Covariate $b_{i 0}$ was a species-specific normal random effect, whereas $b_{1}$ was a fixed effect. Detection parameter estimates for each species were random variables governed by a community-level parameter. We modeled heterogeneity among species using a covariance term $(\rho)$ between species intercepts of occurrence $\left(a_{i 0}\right)$ and detection probability $\left(b_{i 0}\right)$ (Royle and Dorazio, 2008, p. 391). We assumed a multivariate logit scale normal distribution, where the only nonzero off-diagonal elements of the variancecovariance matrix with occupancy and detection parameters were between $a_{i 0}$ and $b_{i 0}$. This covariance term, our data augmentation step, and the assumption that covariates of species were random variables from a common distribution allowed us to make inferences on occupancy and detection probability of species that we never detected.

We calculated the number of species, species richness, at each transect $j$ and year $t$ :

$$
N_{j t}=\sum_{i=1}^{M} z_{i j t} .
$$

We also calculated local species colonization, $(\gamma)$, probability that a species selected at random from the community was not present in the community at time $t-1$, and local species extinction $(\varepsilon)$, or probability that a species selected at random from the community was present at time $t-1$ but not at time $t$ (Williams and others, 2002):

$$
\begin{gathered}
\gamma_{j t}=\frac{\sum_{i=1}^{M}\left(z_{i j t}\right) \times\left(1-z_{i j, t-1}\right)}{\sum_{i=1}^{M} z_{i j, t-1} \text { and }} \\
\varepsilon_{j t}=\frac{\sum_{i=1}^{M}\left(1-z_{i j t}\right) \times\left(z_{i j, t-1}\right)}{\sum^{M} z_{i j, t-1}} .
\end{gathered}
$$

\section{Inference}

We used Bayesian hierarchical models (Gelman and others, 2004) in R2WinBUGS (Sturtz and others, 2005), an R package (R Development Core Team, 2011) that interfaces with WinBUGS (Lunn and others, 2000) to obtain parameter estimates. We used independent non-informative priors because we had no prior knowledge about the parameters: $\Omega \sim \operatorname{Uniform}(0,1), \operatorname{expit}\left(\mu_{a 1(0)}\right) \sim \operatorname{Uniform}(0,1), \sigma_{a 1(0)} \sim$ $\operatorname{Uniform}(0,10), \operatorname{expit}\left(\mu_{a 0}\right) \sim \operatorname{Uniform}(0,1), \sigma_{a 0} \sim \operatorname{Uniform}(0,10)$, $a_{i 1(0)} \sim \operatorname{Uniform}(0,1), \mu_{a 2} \sim \operatorname{Normal}(0,1), \sigma_{a 2} \sim \operatorname{Uniform}(0,10)$, $\mu_{a 3} \sim \operatorname{Normal}(0,1), \sigma_{a 3} \sim \operatorname{Uniform}(0,10), \mu_{a 4} \sim \operatorname{Normal}(0,1), \sigma_{a 4}$ $\sim \operatorname{Uniform}(0,10), \mu_{a 5} \sim \operatorname{Normal}(0,1), \sigma_{a 5} \sim \operatorname{Uniform}(0,10), \mu_{a 6}$ $\sim \operatorname{Normal}(0,1), \sigma_{a 6} \sim \operatorname{Uniform}(0,10), \mu_{a 7} \sim \operatorname{Normal}(0,1), \sigma_{a 7} \sim$ $\operatorname{Uniform}(0,10), \mu_{a 8} \sim \operatorname{Normal}(0,1), \sigma_{a 8} \sim \operatorname{Uniform}(0,10), \mu_{a 9} \sim$ $\operatorname{Normal}(0,1), \sigma_{a 9} \sim \operatorname{Uniform}(0,10), \operatorname{expit}\left(\mu_{b 0}\right) \sim \operatorname{Uniform}(0,1)$, $\sigma_{b 0} \sim \operatorname{Uniform}(0,10), b_{1} \sim \operatorname{Normal}(0,1), \rho \sim \operatorname{Uniform}(-1,1)$. We used data augmentation (Dorazio and others, 2006) to extend inference to the entire community. We used a sufficiently large supercommunity size $M$, so the posterior distribution of $\Omega$ was centered well below its upper limit $(\Omega \leq 0.5)$. We augmented the species observation matrix $\mathbf{y}$ with $\left(M-n_{\text {obs }}\right)$ rows of zeros for all transect $\times$ primary period sampling sessions. We ran four parallel chains (length 50,000 it, burn-in 25,000 it, thinning $20 \mathrm{it}$ ) to estimate the posterior distribution median of model parameters and 95-percent Bayesian Credible Intervals (BCI). We determined statistical significance when 95-percent BCIs did not overlap zero. Convergence was reached $(\hat{R}=1.0-1.1$; Brooks and Gelman, 1998). We assessed goodness-of-fit (GOF) using two statistics (deviance [ $-2 \times \log$-likelihood], squared 
$\left.\operatorname{loss}\left[\sum_{i=1}^{N} \sum_{j=1}^{15} \sum_{t=1}^{10}\left[Y_{\text {expected, } i j t}-Y_{i j t}\right]^{2}\right]\right)$,

where $Y_{i j t}$ is observed data for species $i$, at transect $j$, during year $t$ for a Bayesian $p$-value (Gelman and others, 2004, p. 162). The Bayesian $p$-value is the proportion of replicateddata summary values (deviance, squared loss) that were greater than or equal to the observed value (Gelman and others, 2004, p. 162).

\section{Results}

\section{Data Summary}

We detected 107 bird species (table 2; refer to this table for scientific names of birds discussed in text) over the study period. Total number of species observed on all transects was comparable across years $\left(n_{\text {obs,yr }}=[59,54,57,57,60\right.$, $72,60,60,63,65])$. There was evidence of overdispersion (Bayesian $p$-value deviance $=0.7112$, Bayesian $p$-value squared loss $=1.0$ ). Histograms of median posterior estimates of detection probabilities were bimodal and detection probabilities varied by species, but histograms were similar for all transects (fig. 2). Detection probabilities increased with increased sampling effort (median $\hat{b}_{1}=0.4424$, 95-percent $\mathrm{BCI}=0.3938-0.4893$ ).

Table 2. Avian species detected during summer breeding seasons after the 1996 Hochderffer and Horseshoe wildfires of northern Arizona.

\begin{tabular}{ll}
\hline \multicolumn{1}{c}{ Common species name } & \multicolumn{1}{c}{ Scientific name } \\
\hline Wild turkey & Meleagris gallopavo \\
Turkey vulture & Cathartes aura \\
Cooper's hawk & Accipiter cooperii \\
Northern goshawk & Accipiter gentilis \\
Sharp-shinned hawk & Accipiter striatus \\
Red-tailed hawk & Buteo jamaicensis \\
Swainson's hawk & Buteo swainsoni \\
Ferruginous hawk & Buteo regalis \\
Peregrine falcon & Falco peregrinus \\
Merlin & Falco columbarius \\
American kestrel & Falco sparverius \\
Prairie falcon & Falco mexicanus \\
Band-tailed pigeon & Patagioenas fasciata \\
Mourning dove & Zenaida macroura \\
Great horned owl & Bubo virginianus \\
Northern pygmy-owl & Glaucidium gnoma \\
Long-eared owl & Asio otus \\
Flammulated owl & Otus flammeolus \\
Lesser nighthawk & Chordeiles acutipennis \\
Common nighthawk & Chordeiles minor
\end{tabular}

Table 2.-Continued

\begin{tabular}{|c|c|}
\hline Common species name & Scientific name \\
\hline Common poor-will & Phalaenoptilus nuttallii \\
\hline Black-chinned hummingbird & Archilochus alexandri \\
\hline Blue-throated hummingbird & Lampornis clemenciae \\
\hline Broad-tailed hummingbird & Selasphorus platycercus \\
\hline Rufous hummingbird & Selasphorus rufus \\
\hline Northern flicker & Colaptes auratus \\
\hline Acorn woodpecker & Melanerpes formicivorus \\
\hline Lewis's woodpecker & Melanerpes lewis \\
\hline Downy woodpecker & Picoides pubescens \\
\hline American three-toed woodpecker & Picoides dorsalis \\
\hline Hairy woodpecker & Picoides villosus \\
\hline Red-naped sapsucker & Sphyrapicus nuchalis \\
\hline Williamson's sapsucker & Sphyrapicus thyroideus \\
\hline Olive-sided flycatcher & Contopus cooperi \\
\hline Western wood-pewee & Contopus sordidulus \\
\hline Hammond's flycatcher & Empidonax hammondii \\
\hline Dusky flycatcher & Empidonax oberholseri \\
\hline Cordilleran flycatcher & Empidonax occidentalis \\
\hline Gray flycatcher & Empidonax wrightii \\
\hline Ash-throated flycatcher & Myiarchus cinerascens \\
\hline Cassin's kingbird & Tyrannus vociferans \\
\hline Western kingbird & Tyrannus verticalis \\
\hline Warbling vireo & Vireo gilvus \\
\hline Hutton's vireo & Vireo huttoni \\
\hline Plumbeous vireo & Vireo plumbeous \\
\hline Pinyon jay & Gymnorhinus cyanocephalus \\
\hline Western scrub-jay & Aphelocoma californica \\
\hline Stellar's jay & Cyanocitta stelleri \\
\hline Mexican jay & Aphelocoma wollweberi \\
\hline Clark's nutcracker & Nucifraga columbiana \\
\hline American crow & Corvus brachyrhynchos \\
\hline Common raven & Corvus corax \\
\hline Horned lark & Eremophila alpestris \\
\hline Violet-green swallow & Tachycineta thalassina \\
\hline Mountain chickadee & Poecile gambeli \\
\hline Bushtit & Psaltriparus minimus \\
\hline Red-breasted nuthatch & Sitta canadensis \\
\hline White-breasted nuthatch & Sitta carolinensis \\
\hline Pygmy nuthatch & Sitta pygmaea \\
\hline Brown creeper & Certhia americana \\
\hline Rock wren & Salpinctes obsoletus \\
\hline House wren & Troglodytes aedon \\
\hline Blue-gray gnatcatcher & Polioptila caerulea \\
\hline Ruby-crowned kinglet & Regulus calendula \\
\hline Golden-crowned kinglet & Regulus satrapa \\
\hline Mountain bluebird & Sialia currucoides \\
\hline Western bluebird & Sialia mexicana \\
\hline Townsend's solitaire & Myadestes townsendi \\
\hline Red-breasted nuthatch & Sitta canadensis \\
\hline White-breasted nuthatch & Sitta carolinensis \\
\hline Pygmy nuthatch & Sitta pygmaea \\
\hline Brown creeper & Certhia americana \\
\hline Rock wren & Salpinctes obsoletus \\
\hline
\end{tabular}




\section{Species Richness}

Table 2.-Continued

\begin{tabular}{|c|c|}
\hline Common species name & Scientific name \\
\hline House wren & Troglodytes aedon \\
\hline Blue-gray gnatcatcher & Polioptila caerulea \\
\hline Ruby-crowned kinglet & Regulus calendula \\
\hline Golden-crowned kinglet & Regulus satrapa \\
\hline Mountain bluebird & Sialia currucoides \\
\hline Western bluebird & Sialia mexicana \\
\hline Townsend's solitaire & Myadestes townsendi \\
\hline Hermit thrush & Catharus guttatus \\
\hline American robin & Turdus migratorius \\
\hline Northern mockingbird & Mimus polyglottos \\
\hline American pipit & Anthus rubescens \\
\hline Cedar waxwing & Bombycilla cedrorum \\
\hline Olive warbler & Peucedramus taeniatus \\
\hline Red-faced warbler & Cardellina rubrifrons \\
\hline Yellow-rumped warbler & Setophaga coronata \\
\hline Grace's warbler & Setophaga graciae \\
\hline Black-throated gray warbler & Setophaga nigrescens \\
\hline Townsend's warbler & Setophaga townsendi \\
\hline Orange-crowned warbler & Oreothlypsis celata \\
\hline Virginia’s warbler & Oreothlypsis virginiae \\
\hline Green-tailed towhee & Pipilo chlorurus \\
\hline Spotted towhee & Pipilo maculatus \\
\hline Rufous-crowned sparrow & Aimophila ruficeps \\
\hline Black-throated sparrow & Amphispiza bilineata \\
\hline Lark sparrow & Chondestes grammacus \\
\hline Brewer's sparrow & Spizella breweri \\
\hline Chipping sparrow & Spizella passerina \\
\hline Vesper sparrow & Pooecetes gramineus \\
\hline Grasshopper sparrow & Ammodramus savannarum \\
\hline Song sparrow & Melospiza melodia \\
\hline Dark-eyed junco & Junco phaeonotus \\
\hline Hepatic tanager & Piranga flava \\
\hline Western tanager & Piranga ludoviciana \\
\hline Summer tanager & Piranga rubra \\
\hline Black-headed grosbeak & Pheucticus melanocephalus \\
\hline Eastern meadowlark & Sturnella magna \\
\hline Western meadowlark & Sturnella neglecta \\
\hline Brewer's blackbird & Euphagus cyanocephalus \\
\hline Brown-headed cowbird & Molothrus ater \\
\hline Bullock's oriole & Icterus bullockii \\
\hline
\end{tabular}

Avian species richness, on average, increased over the 10-year time period for transects, although 95-percent BCIs overlapped for these transects (fig. 3).

Although patterns were not significant because the 95-percent BCIs overlapped, we describe general patterns of the average posterior median species richness estimates for the transects at different severities below. The average posterior median species richness estimate of moderate severity transects $\left(\hat{S} R_{\text {median, avg }}=64, \hat{S} R_{\text {median, sd }}=5\right)$ was greater than high severity transects $\left(\hat{S} R_{\text {median, avg }}=55, \hat{S} R_{\text {median, sd }}=5\right)$ by 9 species over the 10-year period and greater than unburned transects $\left(\hat{S} R_{\text {median, avg }}=50, \hat{S} R_{\text {median, sd }}=5\right)$ by 14 species over the 10 -year period. The average posterior median species richness estimate of high-severity transects was greater than unburned transects by 5 species over the 10-year period. One particular example (unburned for first 3 years and high burn severity for last 7 years for transect $D$ versus unburned for transect $E$ ) is of interest. Posterior median estimates of species richness were similar for the first 3 years when transects D and $\mathrm{E}$ were both

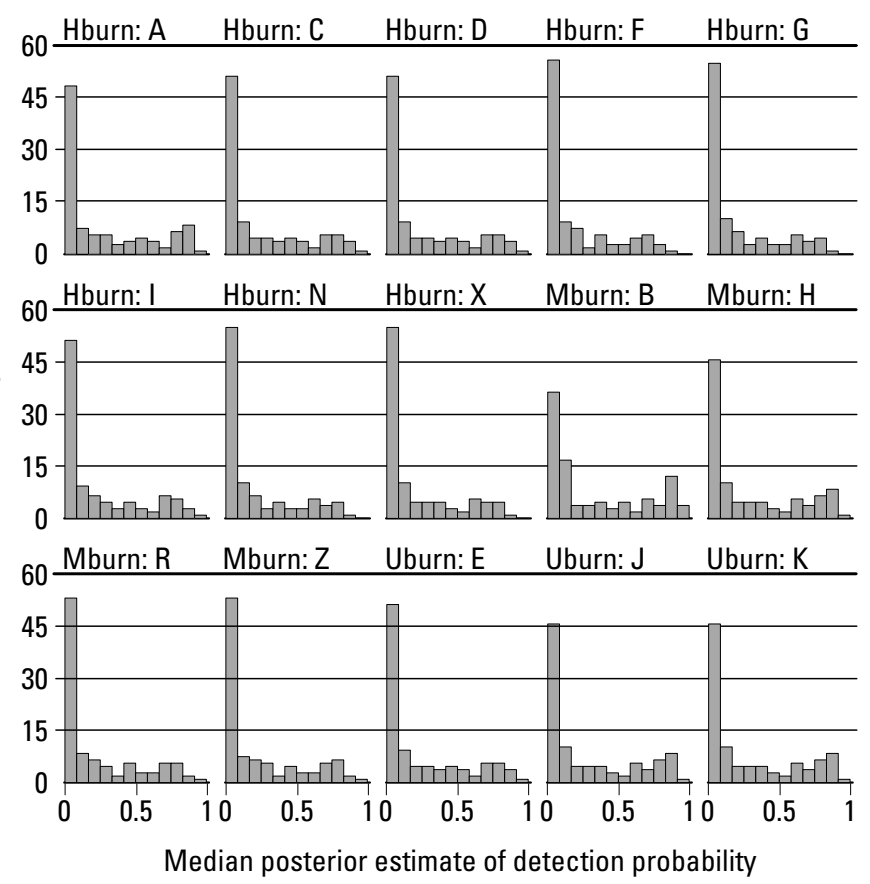

Figure 2. Histograms of median posterior estimates of detection probabilities for avian species at the 15 avian transects (fig. 1) for 10 years after the 1996 Hochderffer and Horseshoe wildfires that occurred in northern Arizona. Subplots are labeled with burn severity and transect name. Note that transect $D$ was classified as unburned for the first 3 years after wildfire and then high severity afterwards. Hburn, high burn severity; Mburn, moderate burn severity; Uburn, unburned. 
unburned; however, median posterior estimates of species richness increased for the high-severity transect $\mathrm{D}$ with time, while the unburned transect $\mathrm{E}$ stayed relatively constant.

\section{Local Colonization and Local Extinction}

We found no clear patterns in local colonization and local extinction over all 10 years for unburned, moderate-burn, and high-burn severity transects (fig. 4) because all 95-percent BCIs overlapped.

In general, posterior median estimates of local colonization were greater than posterior median estimates of local extinction of avian species, which is consistent with posterior median estimates of species richness increasing over the 10-year time period for all transects. Local-colonization posterior median estimates tended to be greater than local extinction estimates for the last 5 years, indicating that local colonization was increasing with time, although not significantly.

\section{Responses of Individual Species}

Occupancy responses of individual species to time and burn severity were not the same (table 3 ). Nine species showed an increase in the probability of occupancy (for example, 95-percent BCI did not include zero) over time. One species, western kingbird, exhibited a significantly negative response to the quadratic form of time, indicating that probability of occupancy was greater in the beginning and ending part of the 10 -year time period. Six species had significantly greater, and one species, Townsend's solitaire, had significantly lower probability of occupancy in moderate burn severity. Seven species had significantly greater and 14 species had significantly lower probability of occupancy in high burn severity. Three species (American kestrel, rock wren, western meadowlark) had significantly higher and one species had significantly lower (Townsend's solitaire) probability of occupancy for both moderate and high burn severity transects. The only significant interaction between burn severity and time or burn severity and the quadratic form of time was with the American kestrel, which had a positive interaction with high-burn severity and time for probability of occupancy.

\section{Discussion}

\section{Burn Severity and Species Richness}

Our results indicate that fire severity is an important driver of species richness, supporting research that fire creates landscape heterogeneity (Brawn and others, 2001). Median posterior estimates for avian species richness on transects that had fire were greater than unburned transects over the 10-year period, and species richness median posterior estimates for moderate severity transects were greater than high severity transects, although the credible intervals did overlap. Similarly, Bock and Block (2005) reported more species in severely burned (45) and moderately burned areas (41) than on unburned areas (31) 3 years post-fire on the same transects. Although the numbers of species detected increased over time for all transects, burned areas still exhibited more species than unburned areas 10 years after fire. Other studies (for example, Fontaine and others, 2009) have documented decreased avian

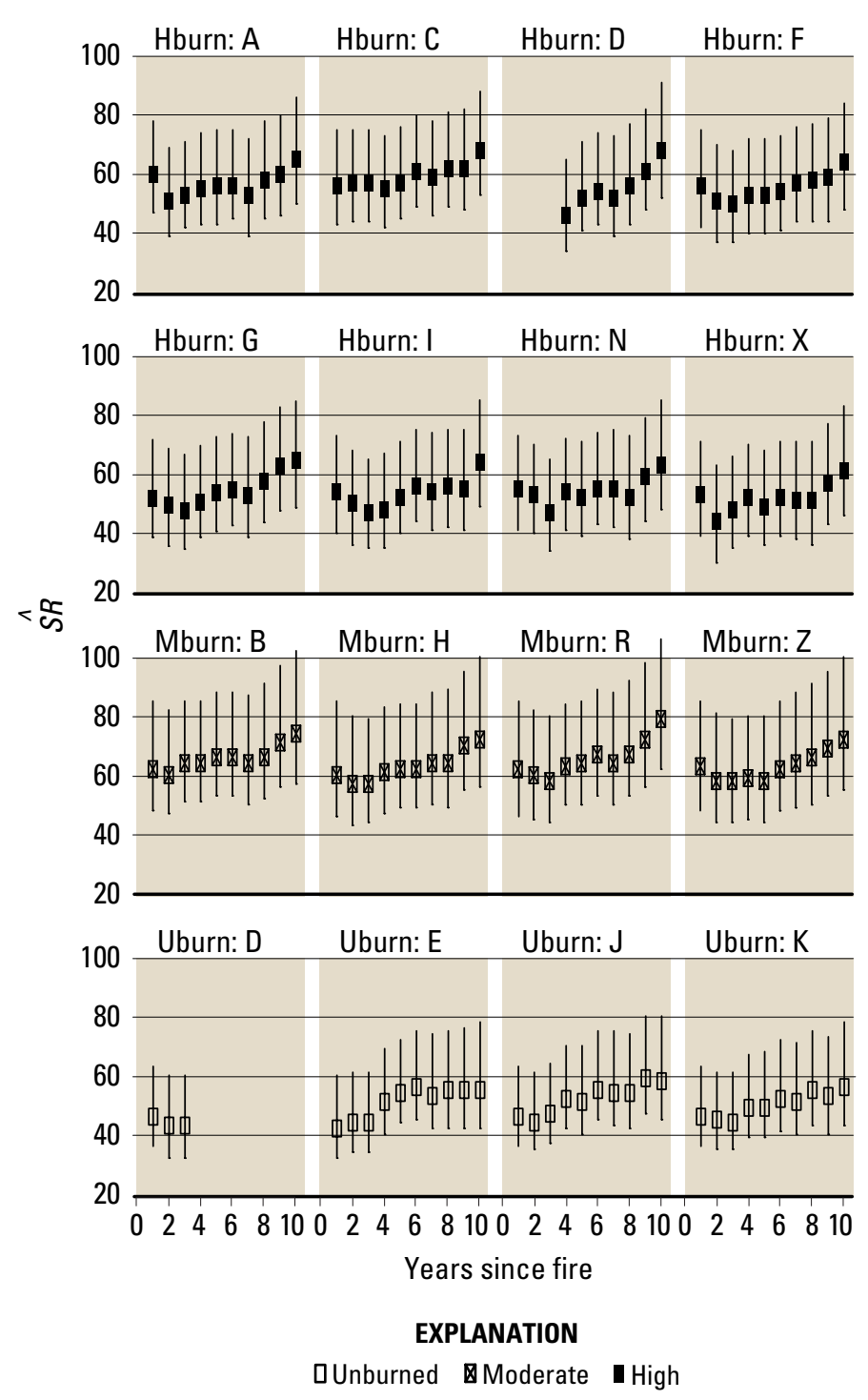

Figure 3. Diagram showing avian community species richness $(\hat{S R})$ posterior estimates and 95-percent Bayesian credible intervals over different burn severity (unburned, white box; moderate burn, box with an $\mathrm{x}$; high burn, black box) transects (fig. 1) for 10 years after the 1996 Hochderffer and Horseshoe wildfires in northern Arizona. Subplots are labeled with burn severity and transect name. Hburn, high burn severity; Mburn, moderate burn severity; Uburn, unburned. 

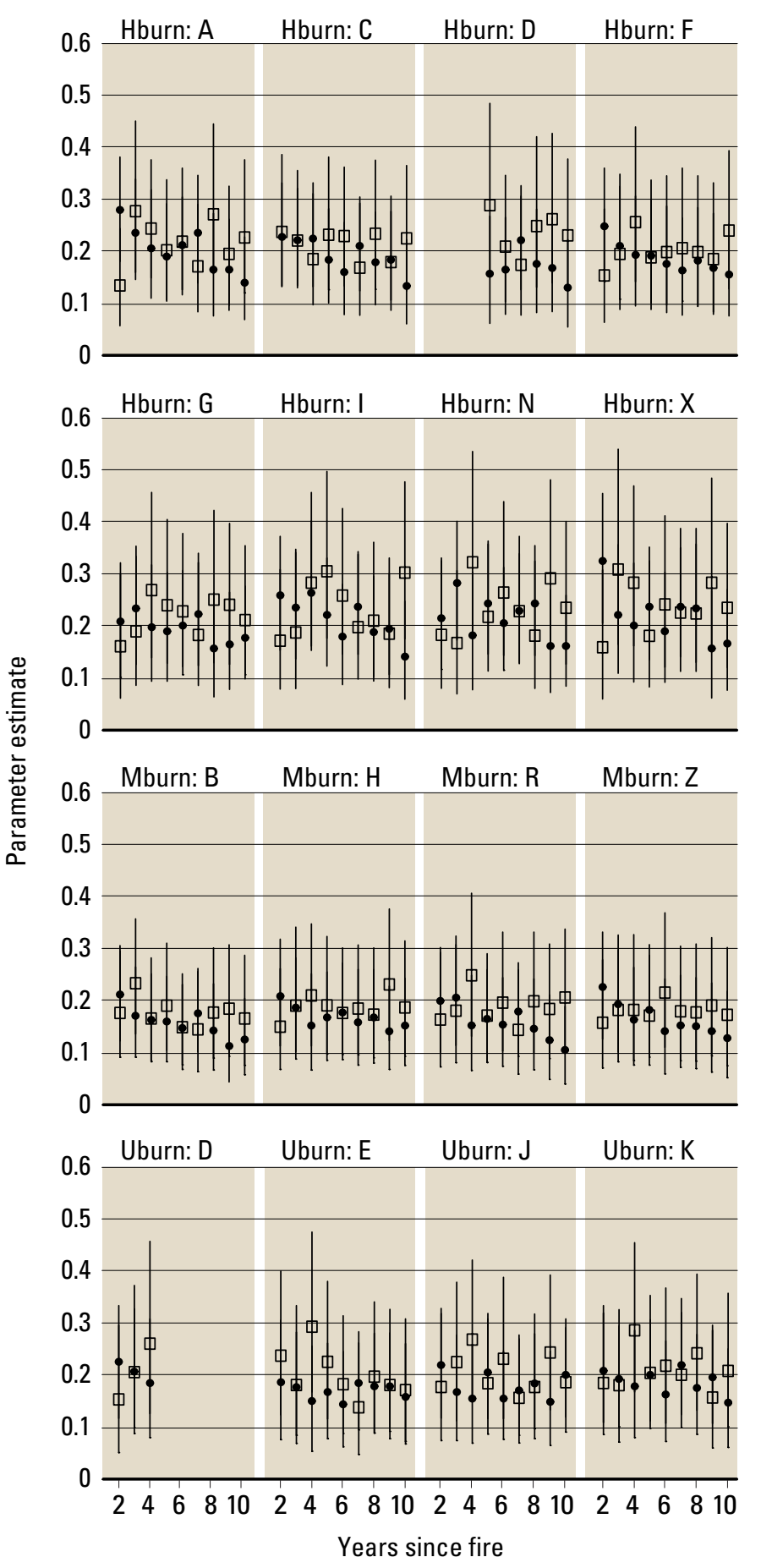

EXPLANATION

- Local extinction aLocal colonization

Figure 4. Diagram showing avian community local extinction (black circle) and local colonization (white box) posterior estimates and 95-percent Bayesian credible intervals for all 15 avian transects (fig. 1) for 10 years after the 1996 Hochderffer and Horseshoe wildfires in northern Arizona. Subplots are labeled with burn severity and transect name. Hburn, high burn severity; Mburn, moderate burn severity; Uburn, unburned. densities with high-severity fire but not necessarily changes in species richness. Hurteau and others (2008) did not detect differences in species richness over different experimental fuelreduction treatments (thin to reduce stem density and basal area only, prescribed burn only, and thin and prescribed burn).

\section{Local Colonization and Local Extinction}

In general, local colonization of avian species was greater than local extinction over the 10 -year period for all transects, which is consistent with our result of species richness increasing over the 10-year time period for all transects. This could be the result of other environmental variables not included in this analysis (that is, rainfall, temperature) or even broader regional trends not specific to our study area.

\section{Burn Severity and Time Since Fire for Individual Species}

Species that showed significant responses to fire within our study followed the general predictions of Saab and Powell (2005) (table 4). As changes in forest structure occur from fire, we would expect some species to respond differently depending on time since fire. Our study includes how species respond to fire with regards to probability of occupancy; however, in the other studies we reference below, it is important to note that species response could be based on occupancy, counts not adjusted for detection probability, abundance, density, or nest density. Early postdisturbance vegetation structure after fire includes snags and groundcover from herbs. Aerial and ground insectivores, bark and wood foragers, and cavity nesters tend to favor burned habitats. Examples of aerial insectivores that positively responded to fire from our study and other studies included Lewis's woodpecker (Hutto and others, 2008; Saab and Dudley, 1998; Saab and others, 2007) and the olive-sided flycatcher (Kalies and others, 2010; Kotliar and others, 2002; Lowe and others, 1978; Raphael and others, 1987; Smucker and others, 2005). The common nighthawk, also an aerial insectivore, responded positively to fire in other studies (Bock and Bock, 1978; Kalies and others, 2010) but responded negatively to fire in our study. The Cassin's kingbird and western kingbird are also aerial insectivore species that we would expect to positively respond to fire (Bock and Bock, 1978; Kirkpatrick and others, 2006), but we did not detect a significant response to fire in our study. Cassin's kingbird occupancy positively increased and western kingbird occupancy negatively decreased with time for all transects, suggesting that factors not accounted for in our study influenced these species instead. Examples of ground insectivores that positively responded to fire from our study and other studies included house wren (Blake, 1982; Kirkpatrick and others, 2006; Kotliar and others, 2007; Raphael and others, 1987), mountain bluebird (Bock and Bock, 1983; Dieni and Anderson, 1999; Kotliar and others, 2002; Lowe and others, 
Table 3. Wildfire responses by individual avian species following the 1996 Hochderffer and Horseshoe wildfires in northern Arizona.

\begin{abstract}
[All significant positive (+) and negative (-) for covariates time, time2, moderate burn severity (Mburn), high burn severity (Hburn), and interactions were noted. Species not listed did not exhibit significant relationships with fire severity, time, or their interaction. There were no significant relations for the interactions of burn severity and time2. Scientific names of species are in table 2]
\end{abstract}

\begin{tabular}{|c|c|c|c|c|c|c|}
\hline $\begin{array}{c}\text { Common species } \\
\text { name }\end{array}$ & time & time2 & Mburn & Hburn & $\begin{array}{l}\text { Mburn } \\
\times \text { time }\end{array}$ & $\begin{array}{l}\text { Hburn } \\
\text { x time }\end{array}$ \\
\hline Red-tailed hawk & & & + & & & \\
\hline American kestrel & & & + & + & & + \\
\hline Common nighthawk & & & & - & & \\
\hline $\begin{array}{l}\text { Broad-tailed } \\
\text { hummingbird }\end{array}$ & + & & & & & \\
\hline Lewis's woodpecker & & & & + & & \\
\hline $\begin{array}{l}\text { Olive-sided } \\
\text { flycatcher }\end{array}$ & & & & + & & \\
\hline $\begin{array}{l}\text { Ash-throated } \\
\text { flycatcher }\end{array}$ & + & & & & & \\
\hline Cassin's kingbird & + & & & & & \\
\hline Western kingbird & - & & & & & \\
\hline Warbling vireo & + & & & - & & \\
\hline Plumbeous vireo & & & & - & & \\
\hline Mountain chickadee & & & & - & & \\
\hline $\begin{array}{l}\text { Red-breasted } \\
\text { nuthatch }\end{array}$ & + & & & & & \\
\hline $\begin{array}{l}\text { White-breasted } \\
\text { nuthatch }\end{array}$ & & & & - & & \\
\hline Pygmy nuthatch & + & & & - & & \\
\hline Brown creeper & & & & - & & \\
\hline Rock wren & + & & + & + & & \\
\hline House wren & & & & + & & \\
\hline Mountain bluebird & & & & + & & \\
\hline Townsend's solitaire & & & - & - & & \\
\hline Olive warbler & & & & - & & \\
\hline $\begin{array}{l}\text { Yellow-rumped } \\
\text { warbler }\end{array}$ & & & & - & & \\
\hline Grace's warbler & & & & - & & \\
\hline Virginia's warbler & & & & - & & \\
\hline Lark sparrow & + & & & & & \\
\hline Chipping sparrow & + & & + & & & \\
\hline Western tanager & & & & - & & \\
\hline Western meadowlark & & & + & + & & \\
\hline $\begin{array}{l}\text { Brown-headed } \\
\text { cowbird }\end{array}$ & & & + & - & & \\
\hline
\end{tabular}

1978; Raphael and others, 1987; Smucker and others, 2005), and rock wren (Blake, 1982; Kotliar and others, 2002). We expected broad-tailed hummingbirds to respond positively to fire due to an increase in flowers as in other studies (Bock and Block, 2005; Kalies and others, 2010; Kotliar and others, 2007), but we did not detect a positive response to fire in our study. We did, however, have a significant increase in occupancy of broad-tailed hummingbirds with time across all transects, suggesting that factors not accounted for in our study influenced this species. The only significant interaction between burn severity and time was with the American kestrel, which had a positive interaction with high-burn severity and time for probability of occupancy, indicating as time increases after fire probability of occupancy increases. This is likely the result of increased prey abundance, availability of nest cavities, and open habitat structure after fire. Similar patterns have been documented with the American kestrel in other studies (Kalies and others, 2010; Lowe and others, 1978; Saab and Dudley, 1998; Saab and others, 2007).

As time progresses, snags fall and the understory develops with more shrubs. We would expect omnivores and shrub nesters to do well when this happens. One example of an omnivore that responded positively to fire in our study and other studies was the chipping sparrow (Bock and Bock, 1983; Lowe and others, 1978; Raphael and others, 1987; Smucker and others, 2005). Finally, as the forest matures, the structure is characterized by a closed canopy with few snags and low understory development, whereas old-growth forests include snags, an open canopy, and an understory that starts to develop. Saab and Powell (2005) found that foliage gleaners preferred unburned habitats, which was true with all our species with significant negative responses to fire. Examples of foliage insectivores with negative responses to fire in our study and other studies included warbling vireo (Dieni and Anderson, 1999; Kotliar and others, 2002) 3 to 6 years after fire (Bagne and Purcell, 2011; Kirkpatrick and others, 2006; Kotliar and others, 2007), yellow-rumped warbler (Kotliar and others, 2007; Raphael and others, 1987; Smucker and others, 2005), western tanager (Raphael and others, 1987; Smucker and others, 2005), and plumbeous vireo (Kotliar and others, 2002). Examples of secondary cavity-nesting species that had negative responses to fire in our study and other studies included mountain chickadee (Dwyer and Block, 2000; Hurteau and others, 2008; Kotliar and others, 2002; Kotliar and others, 2007; Lowe and others, 1978; Saab and Powell, 2005), white-breasted nuthatch (Blake, 1982; Dwyer and Block, 2000), pygmy nuthatch (Blake, 1982; Dickson and others, 2009; Dwyer and Block, 2000; Lowe and others, 1978), and brown creeper (Kotliar and others, 2002; Lowe and others, 1978; Raphael and others, 1987).

We detected only one species that had a mixed response (positive with moderate burn and negative with high severity burn) to wildfire, the brown-headed cowbird. Dieni and Anderson (1999) also found a similar mixed response for the brown-headed cowbird. This is not entirely surprising, 
Table 4. Foraging mode, nest layer, and nest type for species, adapted from criteria of Saab and Powell (2005), with significant responses to wildfire in our study in northern Arizona following the 1996 Hochderffer and Horseshoe wildfires.

[Response to fire from our study: positive (+), negative (-), or both. Foraging mode: $\mathrm{AI}=$ aerial insectivore, $\mathrm{BI}=$ bark insectivore, $\mathrm{FI}=$ foliage insectivore, $\mathrm{GI}=$ ground insectivore, $\mathrm{CA}=$ carnivore, $\mathrm{OM}=$ omnivore, and $\mathrm{SI}=$ shrub insectivore. Nest layers: $\mathrm{GR}=$ ground, $\mathrm{SH}=$ shrub, and $\mathrm{CA}=$ subcanopy to canopy. Nest types: $\mathrm{O}=$ open, $\mathrm{C}=$ closed, and $\mathrm{P}=$ parasitic. Scientific names of species are in table 2]

\begin{tabular}{|c|c|c|c|c|}
\hline Common species name & $\begin{array}{c}\text { Response } \\
\text { to fire } \\
\text { (our study) }\end{array}$ & $\begin{array}{c}\text { Forage } \\
\text { mode }\end{array}$ & $\begin{array}{l}\text { Nest } \\
\text { layer }\end{array}$ & $\begin{array}{l}\text { Nest } \\
\text { type }\end{array}$ \\
\hline Red-tailed hawk & + & $\mathrm{CA}$ & $\mathrm{CA}$ & $\mathrm{O}$ \\
\hline American kestrel & + & $\mathrm{CA}$ & $\mathrm{CA}$ & $\mathrm{C}$ \\
\hline Common nighthawk & - & AI & GR & $\mathrm{O}$ \\
\hline Lewis's woodpecker & + & $\mathrm{AI}$ & $\mathrm{CA}$ & $\mathrm{C}$ \\
\hline Olive-sided flycatcher & + & AI & $\mathrm{CA}$ & $\mathrm{O}$ \\
\hline Warbling vireo & - & FI & $\mathrm{CA}$ & $\mathrm{O}$ \\
\hline Plumbeous vireo & - & FI & $\mathrm{CA}$ & $\mathrm{O}$ \\
\hline Mountain chickadee & - & FI & $\mathrm{CA}$ & $\mathrm{C}$ \\
\hline White-breasted nuthatch & - & $\mathrm{BI}$ & $\mathrm{CA}$ & $\mathrm{C}$ \\
\hline Pygmy nuthatch & - & BI & $\mathrm{CA}$ & $\mathrm{C}$ \\
\hline Brown creeper & - & $\mathrm{FI} / \mathrm{BI}$ & $\mathrm{CA}$ & $\mathrm{C}$ \\
\hline Rock wren & + & GI & GR & $\mathrm{C}$ \\
\hline House wren & + & GI & $\mathrm{CA}$ & $\mathrm{C}$ \\
\hline Mountain bluebird & + & GI/AI & $\mathrm{CA}$ & $\mathrm{C}$ \\
\hline Townsend's solitaire & - & AI & GR & $\mathrm{O}$ \\
\hline Olive warbler & - & FI & $\mathrm{CA}$ & $\mathrm{O}$ \\
\hline Yellow-rumped warbler & - & FI & $\mathrm{CA}$ & $\mathrm{O}$ \\
\hline Grace's warbler & - & FI & $\mathrm{CA}$ & $\mathrm{O}$ \\
\hline Virginia's warbler & - & SI & SH & $\mathrm{O}$ \\
\hline Chipping sparrow & + & $\mathrm{OM}$ & SH & $\mathrm{O}$ \\
\hline Western tanager & - & FI & $\mathrm{CA}$ & $\mathrm{O}$ \\
\hline Western meadowlark & + & GI & GR & $\mathrm{O}$ \\
\hline Brown-headed cowbird & both & $\mathrm{OM}$ & - & $\mathrm{P}$ \\
\hline
\end{tabular}

depending on what host species the brown-headed cowbird is targeting for parasitizing. Brown-headed cowbird hosts in the western United States include the plumbeous vireo, western tanager, and warbling vireo (for example, Goguen and others, 2009; Marvil and Cruz, 1989; Ortega and Ortega, 2003), which had negative responses with high-severity burn in our study, mirroring the negative response of high-severity burn with the brown-headed cowbird. Similarly, the chipping sparrow, also a brown-headed cowbird host (for example, Ortega and Ortega, 2001), had a positive response to moderate-severity burn in our study, mirroring the positive response to moderate severity burn with the brown-headed cowbird.

Historical conditions in ponderosa pine forests of northern Arizona were characterized by an open park-like structure (Covington and others, 1997). The unburned areas used as contrasts in our study exhibited higher tree densities than found historically in ponderosa pine forests as the result of livestock grazing, logging, and fire suppression (Allen and others, 2002; Covington and Moore, 1994; Moore and others, 1999; Swetnam and others, 1999). We sampled birds within unburned forest to contrast with areas of moderate and high burn severity. The unburned areas did not represent historical forest conditions.

Our study demonstrates the importance of fire for providing and maintaining habitat for many species. Not all species responded similarly, as some species showed affinity to severely burned forests, whereas others favored moderately burned or unburned forest. We need to fine tune this work by incorporating covariates that may better explain bird-habitat relations. Future research with this study will include the influence of burn severity and patch size (Saab and others, 2005), using dNBR at points instead of broad fire-severity categories and including weather and vegetation covariates. These additions will aid resource managers in characterizing the forest vegetation structure for desired management actions.

\section{Management Implications}

Our results indicate the importance of monitoring avian species for longer periods of time following wildfire. Many studies are restricted to 2 to 3 years post-fire, and the results from such studies may not capture long-term effects. At the landscape scale, overall species richness can be maximized by increasing landscape heterogeneity from different fire severities. These patches will have different species compositions, leading to an increase in species richness at the landscape scale. Avian species in pine forests evolved with fire. Given that some species demonstrated an affinity to severely burned forests suggests that similar conditions existed historically. Given behavior of contemporary fire, we envision ample severely burned forest in the foreseeable future.

Unknown, however, is information that outlines the amount and distribution of patches across the landscape. Research is needed that addresses the temporal and spatial aspects of fire and fire severity including the size, shape, juxtaposition, and interspersion of patch sizes across the landscape. 


\section{Acknowledgments}

We thank Jill Dwyer, Laura Doll, Laura Dickson, Laura McGrath, Terry Pope, Gabe Martinez, Jose Iniguez, Brenda Strohmeyer, and Scott Vojta for collecting avian and vegetation data. We also thank the Coconino National Forest, Flagstaff Ranger District; National Fire Plan for funding (J. Sanderlin); J. Iniguez for assistance with maps; J.G. Dudley for calculations of delta normalized burn ratio (dNBR); C. Sieg for assistance with computing power; and E. Kailes and L.S. Baggett and two anonymous reviewers for helpful comments during review.

\section{References Cited}

Allen, C.D., Savage, M., Falk, D.A., Suckling, K.F., Swetnam, T.W., Schulke, T., Stacey, P.B., Morgan, P., Hoffman, M., and Klingel, J.T., 2002, Ecological restoration of southwestern ponderosa pine ecosystems - A broad perspective: Ecological Applications, v. 12, no. 5, p. 1418-1433, http://dx.doi. org/10.1890/1051-0761(2002)012[1418:EROSPP]2.0.CO;2.

Bagne, K.E., and Purcell, K.L., 2011, Short-term responses of birds to prescribed fire in fire-suppressed forests of California: The Journal of Wildlife Management, v. 75, no. 5, p. 1051-1060, http://dx.doi.org/10.1002/jwmg.128.

Blake, J.G., 1982, Influence of fire and logging on nonbreeding bird communities of ponderosa pine forests: The Journal of Wildlife Management, v. 46, no. 2, p. 404-415, http://www.jstor.org/stable/3808652.

Bock, C.E., and Block, W.M., 2005, Fire and birds in the southwestern United States, in Saab, V., and Powell, H.D.W., eds., Fire and avian ecology in North AmericaStudies in avian biology no. 30: Camarillo, Calif., Cooper Ornithological Society, p. 14-32, http://www.treesearch. fs.fed.us/pubs/24000.

Bock, C.E., and Bock, J.H., 1978, Response of birds, small mammals, and vegetation to burning sacaton grasslands in southeastern Arizona: Journal of Range Management, v. 31, no. 4, p. 296-300, https://journals.uair.arizona.edu/index. php/jrm/article/view/6847/6457.

Bock, C.E., and Bock, J.H., 1983, Responses of birds and deer mice to prescribed burning in ponderosa pine: The Journal of Wildlife Management, v. 47, no. 3, p. 836-840, http:// www.jstor.org/stable/3808621.

Brawn, J.D., Robinson, S.K., and Thompson, F.R., 2001, The role of disturbance in the ecology and conservation of birds: Annual Revew of Ecology and Systematics, v. 32, p. 251-276, http://dx.doi.org/10.1146/annurev. ecolsys.32.081501.114031.
Brooks, S.P., and Gelman, A., 1998, General methods for monitoring convergence of iterative simulations: Journal of Computational and Graphical Statistics, v. 7, no. 4, p. 434-455, http://dx.doi.org/10.1080/10618600.1998.104 74787.

Covington, W.W., Fule, P.Z., Moore, M.M., Hart, S.C., Kolb, T.E., Mast, J.N., Sackett, S.S., and Wagner, M.R., 1997, Restoring ecosystem health in ponderosa pine forests of the southwest: Journal of Forestry, v. 95, no. 4, p. 23-29, accessed on April 29, 2015, at http://www.fs.fed.us/psw/ publications/4403/Restoring.pdf.

Covington, W.W., and Moore, M.M., 1994, Southwestern ponderosa forest structure-Changes since EuroAmerican settlement: Journal of Forestry, v. 92, no. 1, p. 39-47, http://library.eri.nau.edu/gsdl/collect/erilibra/ index/assoc/HASH01c1.dir/doc.pdf.

Dickson, B.G., Fleishman, E., Dobkin, D.S., and Hurteau, S.R., 2009, Relationship between avifaunal occupancy and riparian vegetation in the central Great Basin (Nevada, U.S.A.): Restoration Ecology, v. 17, no. 5, p. 722-730, http://dx.doi.org/10.1111/j.1526100X.2009.00590.x.

Dieni, J.S., and Anderson, S.H., 1999, Effects of recent burning on breeding bird community structure in aspen forests: Journal of Field Ornithology, no. 4, p. 491-503, http://www.jstor.org/stable/451444270.

Dorazio, R.M., Royle, J.A., Söderström, B., and Glimskär, A., 2006, Estimating species richness and accumulation by modeling species occurrence and detectability: Ecology, v. 87, no. 4, p. 842-854, http://137.227.245.162/ prodabs/ab04060906/6549_Dorazio.pdf.

Dwyer, J.K., and Block, W.M., 2000, Effects of wildfire on densities of secondary cavity-nesting birds in ponderosa pine forests of northern Arizona, in Moser, W.K., and Moser, C.F., eds., Fire and forest ecologyInnovative silviculture and vegetation managementTall Timbers Fire Ecology Conference Proceedings, no. 21: Tallahassee, Fla., Tall Timbers Research Station, p. 151-156, http://www.treesearch.fs.fed.us/pubs/9148.

Eidenshink, J., Schwind, B., Brewer, K., Zhu, Z.-L., Quayle, B., and Howard, S., 2007, A project for monitoring trends in burn severity: Fire Ecology, v. 3, no. 1, p. 3-21, http:// naldc.nal.usda.gov/catalog/16261.

Fontaine, J.B., Donato, D.C., Robinson, W.D., Law, B.E., and Kauffman, J.B., 2009, Bird communities following high-severity fire-Response to single and repeat fires in a mixed-evergreen forest, Oregon, USA: Forest Ecology and Management, v. 257, no. 10, p. 1496-1504, http:// dx.doi.org/10.1016/j.foreco.2008.12.030. 
Gelman, A., Carlin, J.B., Stern, H.S., and Rubin, D.B., 2004, Bayesian data analysis (2d ed.): Boca Raton, Fla., Chapman and Hall/CRC Press.

Goguen, C.B., Curson, D.R., and Mathews, N.E., 2009, Effects of parasitism by brown-headed cowbirds (Molothrus ater) on reproductive success of three frequent hosts in New Mexico: The Southwestern Naturalist, v. 54, no. 1, p. 58-67, http://dx.doi.org/10.1894/MH-44.1.

Hurteau, S.R., Sisk, T.D., Block, W.M., and Dickson, B.G., 2008, Fuel-reduction treatment effects on avian community structure and diversity: The Journal of Wildlife Management, v. 72, no. 5, p. 1168-1174, http://dx.doi. org/10.2193/2007-351.

Hutto, R.L., Conway, C.J., Saab, V., and Walters, J.R., 2008, What constitutes a natural fire regime? Insight from the ecology and distribution of coniferous forest birds in North America: Fire Ecology Special Issue, v. 4, no. 2, p. 115132, http://www.treesearch.fs.fed.us/pubs/31902.

Kalies, E.L., Chambers, C.L., and Covington, W.W., 2010, Wildlife responses to thinning and burning treatments in southwestern conifer forests - A meta-analysis: Forest Ecology and Management, v. 259, no. 3, p. 333-342, http:// dx.doi.org/10.1016/j.foreco.2009.10.024.

Kirkpatrick, C., Conway, C.J., and Jones, P.B., 2006, Distribution and relative abundance of forest birds in relation to burn severity in southeastern Arizona: The Journal of Wildlife Management, v. 70, no. 4, p. 1005-1012, http://dx.doi.org/10.2193/0022-541X(2006)70[1005:DARA $\mathrm{OF}] 2.0 . \mathrm{CO} ; 2$.

Kotliar, N.B., Hejl, S.J., Hutto, R.L., Saab, V.A., Melcher, C.P., and McFadzen, M.E., 2002, Effects of fire and post-fire salvage logging on avian communities in coniferdominated forests of the western United States: Studies in Avian Biology, v. 25, p. 49-64, http://dbs.umt.edu/research labs/huttolab/PDF/publications/2002-Kotliaretal-SAB.pdf.

Kotliar, N.B., Kennedy, P.L., and Ferree, K., 2007, Avifaunal responses to fire in southwestern montane forests along a burn severity gradient: Ecological Applications, v. 17, no. 2, p. 491-507, http://www.jstor.org/stable/40061873.

Lowe, P.O., Ffolliott, P.F., Dieterich, J.H., and Patton, D.R., 1978, Determining potential wildlife benefits from wildfire in Arizona ponderosa pine forests: Fort Collins, Colo., U.S. Forest Service, Rocky Mountain Forest and Range Experiment Station, general technical report RM-52, 13 p., http://www.fs.fed.us/rm/pubs_rm/rm_gtr052.pdf.

Lunn, D.J., Thomas, A., Best, N., and Spiegelhalter, D.J., 2000, WinBUGS - A Bayesian modelling frameworkConcepts, structure, and extensibility: Statistics and Computing, v. 10, no. 4, p. 325-337, http://dx.doi. org/10.1023/A:1008929526011.
MacKenzie, D.I., Nichols, J.D., Royle, J.A., Pollack, K.H., Bailey, L.L., and Hines, J.E., 2006, Occupancy estimation and modeling - Inferring patterns and dynamics of species occurrence: San Diego, Calif., Academic Press, 324 p.

Marvil, R.E., and Cruz, A., 1989, Impact of the brown-headed cowbird parasitism on the reproductive success of the solitary vireo: The Auk, v. 106, no. 3, p. 476-480, http:// www.jstor.org/stable/4087871.

Moir, W.H., Geils, B.W., Benoit, M.A., and Scurlock, D., 1997, Ecology of southwestern ponderosa pine forests, in Block, W.M., and Finch, D.M., eds., Songbird ecology in southwestern ponderosa pine forests-A literature review: Fort Collins, Colo., U.S. Department of Agriculture, Forest Service, Rocky Mountain Forest and Range Experiment Station, general technical report RM-GR-292, p. 3-27, http://www.fs.fed.us/rm/pubs_rm/rm_gtr292.pdf.

Moore, M.M., Covington, W.W., and Fulé, P.Z., 1999, Reference conditions and ecological restoration-A southwestern ponderosa pine perspective: Ecological Applications, v. 9, no. 4, p. 1266-1277, http://dx.doi. org/10.1890/1051-0761(1999)009[1266:RCAERA]2.0.CO;2.

Ortega, C.P., and Ortega, J.C., 2001, Effects of brown-headed cowbirds on the nesting success of chipping sparrows in southwest Colorado: The Condor, v. 103, no. 1, p. 127-33, http://www.jstor.org/stable/1369685.

Ortega, C.P., and Ortega, J.C., 2003, Brown-headed cowbird (Molothrus ater) parasitism on warbling vireos (Vireo gilvus) in southwest Colorado: The Auk, v. 120, no. 3, p. 759-764, http://www.jstor.org/stable/4090105.

Platt, W.J., and Connell, J.H., 2003, Natural disturbances and directional replacement of species: Ecological Monographs, v. 73, no. 4, p. 507-522, http://www.jstor.org/ stable/4134784.

Raphael, M.G., Morrison, M.L., and Yoder-Williams, M.P., 1987, Breeding bird populations during twenty-five years of postfire succession in the Sierra Nevada: The Condor, v. 89, no. 3, p. 614-626, http://www.jstor.org/ stable/1368651.

R Development Core Team, 2011, R-A language and environment for statistical computing: Vienna, Austria, R Foundation for Statistical Computing, http:/www.Rproject.org.

Reynolds, R.T., Scott, J.M., and Nussbaum, R.A., 1980, A variable circular-plot method for estimating bird numbers: The Condor, v. 82, no. 3, p. 309-313, http://www.jstor.org/ stable/1367399.

Royle, J.A., and Dorazio, R.M., 2008, Hierarchical modeling and inference in ecology-The analysis of data from populations, metapopulations and communities: Burlington, Mass., Academic Press, http:/www.sciencedirect.com/ science/book/9780123740977. 
Russell, R.E., Royle, J.A., Saab, V.A., Lehmkuhl, J.F., Block, W.M., and Sauer, J.R., 2009, Modeling the effects of environmental disturbance on wildlife communities-Avian responses to prescribed fire: Ecological Applications, v. 19, no. 5, p. 1253-1263, http://dx.doi.org/10.1890/08-0910.1.

Saab, V.A., and Dudley, J.G., 1998, Responses of cavity-nesting birds to stand-replacement fire and salvage logging in ponderosa pine/Douglas-fir forests of southwestern Idaho: Ogden, Utah, U.S. Department of Agriculture, Forest Service, Rocky Mountain Research Station, research paper RMRS-RP-11, 17 p., http://www.treesearch.fs.fed.us/pubs/23853.

Saab, V.A., and Powell, H.D.W., 2005, Fire and avian ecology in North America-Process influencing pattern, in Saab, V.A., and Powell, H.D.W., eds., Fire and avian ecology in North America-Studies in avian biology: Camarillo, Calif., Cooper Ornithological Society, p. 1-13, https://sora.unm. edu/sites/default/files/journals/sab/sab_030.pdf.

Saab, V.A., Powell, H.D.W., Kotliar, N.B., and Newlon, K.R., 2005, Variation in fire regimes of the Rocky MountainsImplications for avian communities and fire management, in Saab, V.A., Powell, H.D.W., Kotliar, N.B., and Newlon, K.R., eds., Fire and avian ecology in North AmericaStudies in avian biology, v. no. 30: Camarillo, Calif., Cooper Ornithological Society, p. 76-96 https://sora.unm. edu/sites/default/files/journals/sab/sab_030.pdf.
Saab, V.A., Russell, R.E., and Dudley, J.G., 2007, Nest densities of cavity-nesting birds in relation to postfire salvage logging and time since wildfire: The Condor, v. 109, no. 1, p. 97-108, http://www.jstor.org/ stable/4122535.

Smucker, K.M., Hutto, R.L., and Steele, B.M., 2005, Changes in bird abundance after wildfire-Importance of fire severity and time since fire: Ecological Applications, v. 15, no. 5, p. 1535-1549, http://dx.doi.org/10.1890/041353.

Sturtz, S., Ligges, U., and Gelman, A., 2005, R2WinBUGS - A package for running WinBUGS from R: Journal of Statistical Software, v. 12, no. 3, p. 1-16, http:// www.jstatsoft.org/v12/i03/paper.

Swetnam, T.W., Allen, C.D., and Betancourt, J.L., 1999, Applied historical ecology-Using the past to manage for the future: Ecological Applications, v. 9, no. 4, p. 1189-1206, http://dx.doi.org/10.1890/10510761(1999)009[1189:AHEUTP]2.0.CO;2.

Williams, B.K., Nichols, J.D., and Conroy, M.J., 2002, Analysis and management of animal populationsModeling, estimation, and decision making: San Diego, Calif., Academic Press, 817 p. 


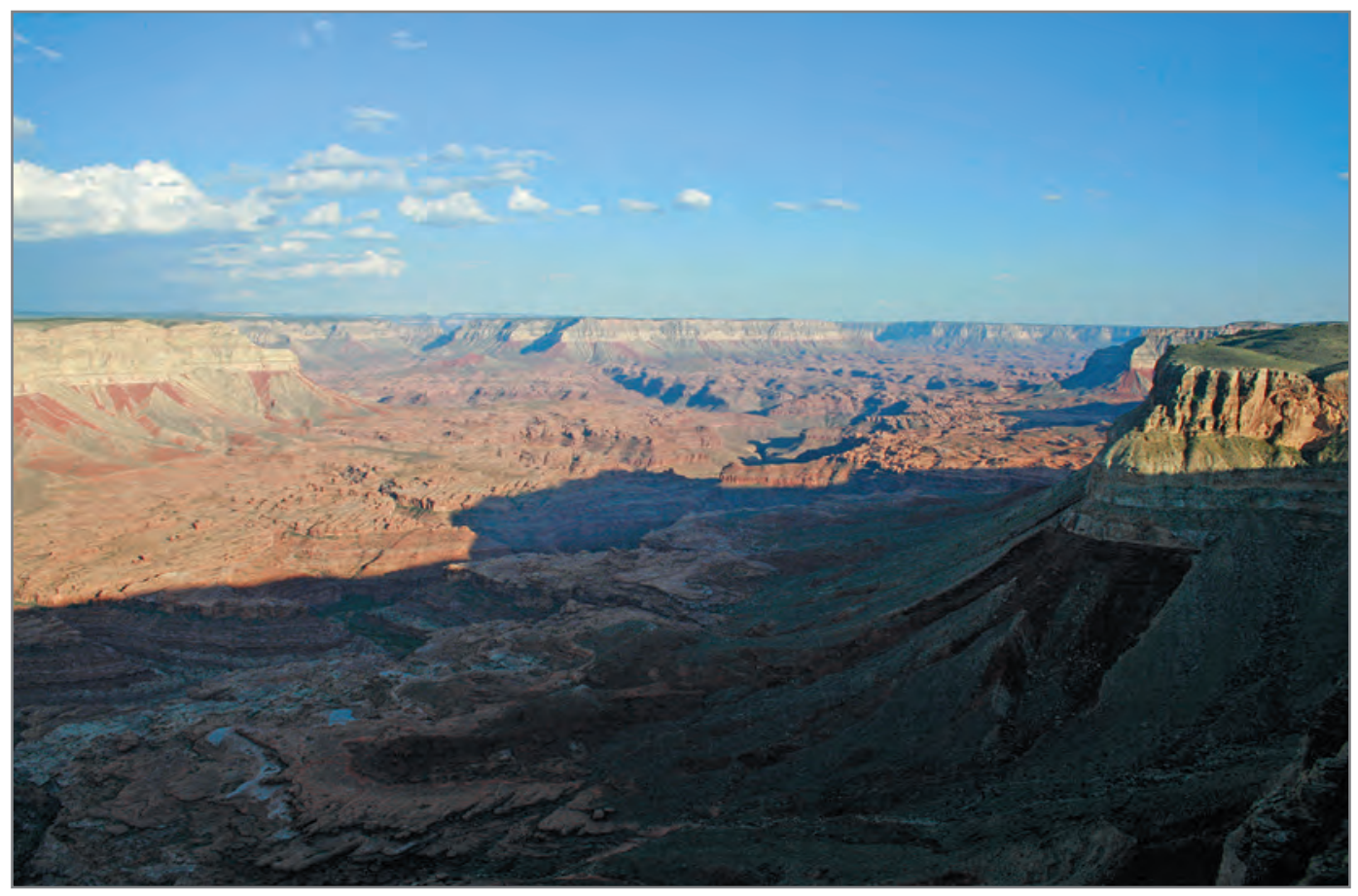

Kanab Basin looking south. Photograph by Robert J. Hart, U.S. Geological Survey. 


\title{
Hunting Methods and Harvest Demographics for Black Bears in Arizona, 1981-2011
}

\author{
By Brian F. Wakeling'
}

\begin{abstract}
Harvest characteristics can be useful data in the evaluation of hunt structures for managed predator species, yet little information is available to assist with the interpretation of harvest characteristics of the American black bear (Ursus americanus). I examined age and sex characteristics obtained from 6,553 harvest reports and 2,910 teeth submitted for cementum aging between 1981 and 2011 in Arizona. I found no evidence that hunters without hounds (boot hunters) or hunters using hounds (hound hunters) were more selective in black bear harvests. I also found no difference in the mean age of male black bears harvested by hound hunters ( 4.7 years) and boot hunters ( 4.6 years), nor between the mean age of female black bears harvested by hound hunters ( 6.5 years) and boot hunters (5.7 years). However, female black bears harvested by both methods were older on average than were male black bears. Although bear harvest in Arizona currently does not appear excessive, should the need for greater restrictions become necessary in the future, season length, season timing, and greater restrictions on female harvests are likely to be more effective than restricting use of hounds in hunting.
\end{abstract}

\section{Introduction}

Predator species harvest management is dependent, in part, on harvest vulnerabilities. For instance, in Arizona, mountain lion (Puma concolor) harvests are accomplished predominately ( 65 percent of total harvest) with the use of hounds (Zornes and others, 2006). Hound hunters harvest more male (about 60 percent of their total take) than female mountain lions, whereas hunters that use calling, observation with binoculars, and stalking (boot hunters) typically harvest more female (about 60 percent of their total take) than male mountain lions (Zornes and others, 2006). Hound hunters also harvest older male mountain lions, on average, than do boot hunters in Arizona (Wakeling and others, 2015). The effect of

${ }^{1}$ Nevada Department of Wildlife, Game Division these harvest demographics is that, although hound hunters harvest more mountain lions overall than do boot hunters, their harvest is more selective and less likely to negatively influence the mountain lion population. This knowledge may be useful when formulating hunting regulations.

Less information is currently available regarding the harvest of black bears (Ursus americanus) in Arizona. Black bear harvest is regulated in Arizona to maintain a median harvest age of female black bears of $>5$ years, in conjunction with a maximum harvest of $<10$ percent of the total estimated adult female segment of the population. Although population estimates of black bears in Arizona are imprecise, management units where these estimates have been verified through the use of genetic mark-recapture studies have proven them to be conservative (for example Atwood and others, 2011; Cunningham and Wakeling, 2011). Black bear hunting regulations have been increasingly restrictive over time with the intent of limiting harvest. A permit has been required to hunt black bears since 1954, and they have been classified as big game by State statute since 1968 (Cunningham and Wakeling, 2011). Restrictions on the use of baiting were first implemented in 1982 and soon expanded statewide. Spring hunts were first authorized in 1985, but the use of hounds during these seasons was precluded. In 1992, Arizona first implemented female harvest limits, which if reached in the harvest, would close the season to further take of bears in that area during the hunt. Cunningham and Wakeling (2011) reported that between 1998 and 2002, the mean ages of harvested males and females were 5.9 and 6.2 years, respectively, yet they acknowledge that age and sex composition of the harvest may vary substantially among years. For instance, they report that yearlings composed 42 percent of the harvest between 1998 and 2000, whereas they only composed 3 percent during 2001 and 2002. Still, little has been published regarding the demographics of black bear harvest with respect to harvest method when compared with mountain lion harvests.

Arizona implemented a mandatory black bear harvest reporting and checking procedure in 1981. I analyzed age and sex of the harvested animals as documented through these mandatory checks to determine if differences existed in harvest characteristics by harvest methods. This information can be useful in promulgating future regulation if needed. 


\section{Study Area}

Black bears occupy about 32,000 square kilometers $\left(\mathrm{km}^{2}\right)$ in Arizona, and inhabit Madrean evergreen, mixed-conifer, spruce (Picea spp.), fir (Abies spp.), ponderosa pine (Pinus ponderosa), and piñon (Pinus edulis)-juniper (Juniperus spp.) woodlands, as well as chaparral communities (Cunningham and Wakeling, 2011). Black bears are found at elevations ranging from about 900 to 2,750 meters (m). In Arizona, black bears are rarely observed in the southwestern deserts or north of the Colorado River. Lawful hunting seasons have been established throughout most occupied range.

\section{Methods}

In Arizona, lawfully harvested black bears must be physically inspected by the Arizona Game and Fish Department. Each black bear is inspected to verify sex and extract a premolar for cementum aging (Dimmick and Pelton, 1996). Because regulations have changed over the years, I compared the number of black bears harvested by method (boot hunting and hound hunting) in three decades (19811990, 1991-2000, 2001-2011) with a chi-square contingency table analysis (Zar, 1984). I similarly compared the number of female black bears harvested by method. I also individually compared the mean age of black bears by sex to determine if changes occurred over time. Finally, I used analysis of variance to determine if differences existed by age among sex and harvest classes, and used Tukey's honest significant difference mean separation test to determine if individual classes differed (Zar, 1984); I considered all differences significant if $P<0.05$.

\section{Results}

I analyzed age data from 2,910 black bears that were physically inspected between 1981 and 2011, and from which premolars could be successfully extracted and age determined. During this time period, 6,553 black bears were physically inspected, but premolars could not always be extracted or usable cememtum age data could not be obtained due to poor sample collection.

During the 1980s and 1990s, only 18 percent of the black bears harvested were taken with the aid of hounds. Since 2000 , this percentage has increased to about 23 percent $\left(X^{2}\right.$ $=32.285$, $\mathrm{df}=2, P<0.001$; table 1$)$. Similarly, although the amount of total female black bear harvest by hound hunters averaged about 18 and 19 percent during the 1980s and 1990 s, respectively, that percentage increased to 25 percent since $2000\left(X^{2}=15.892, \mathrm{df}=2, P<0.001\right.$; table 2$)$. Yet the proportion of the total harvest of female black bears by all hunters has decreased from 40-42 percent during the 1980s and 1990s to about 37 percent since $2000\left(X^{2}=12.75, \mathrm{df}=2\right.$,
$P<0.005$; table 3$)$. This shift was not observed in harvest by hound hunters $\left(X^{2}=2.43, \mathrm{df}=2\right.$, not statistically significant; table 4), but was observed in the harvest by boot hunters $\left(X^{2}=\right.$ 11.435 , $\mathrm{df}=2, P<0.005$; table 5). Since 2000, hound hunters have harvested a larger proportion of the total bear harvest (table 1), although both the total harvest (from $>0.400$ prior to 2000 to $<0.370$ after 2000; table 3 ) and the harvest by boot hunters (from $>0.400$ prior to 2000 to $<0.370$ after 2000 ; table 5) includes a smaller proportion of female black bears.

The age of harvested black bears showed additional correlations with harvest trends. The mean age of female black bears seemed to trend upward regardless of method of take (table 6), as did the mean age of male black bears (table 7). Male black bears harvested by both hunting methods were younger, on average, than were female black bears; however, there was no difference in mean age of either male or female black bears between methods $(P<0.001,3 \mathrm{df}, F=28.03$; table 8$)$.

\section{Discussion}

Although less information regarding the relation between harvest statistics and level of exploitation exists for black bear than for mountain lion, Bunnell and Tait (1985) suggested that harvests composed of equal proportions of male and female bears were indicative of overharvest. During the last decade in Arizona (2001-11), about 63 percent of the total harvest was male and 64 percent of the harvest by boot hunters was male. About 62 percent of hound hunter harvests were male, but harvest by hound hunters only composed 24 percent of the total harvest. The total harvest has shifted from 60 percent male during 1981-1990 and 58 percent male during 19912000 , to a slightly larger proportion (63 percent) since then. There has been no detectable shift in harvest by hound hunters; that pattern in harvest characteristics is similar although the magnitude is somewhat less.

Inferences about effects of harvest can be difficult without knowledge of the age structure of the black bear population itself. For instance, mean age in heavily exploited black bear populations was determined to be 4.5 years in north-central Arizona above the Mogollon Rim (LeCount, 1987) and 4.9 years in the White Mountains of Arizona (LeCount, 1990), whereas the mean age in a lightly exploited population was 8.1 years in central Arizona (LeCount, 1982). LeCount (1990) recommended implementing management strategies that yielded greater proportions of males in the harvest and harvests of black bears that were $\geq 6$ years of age on average. Arizona harvests appear to be meeting these objectives, but changes over time seem to be most influenced by adaptive regulations (for example, eliminating the use of baits and season timing). For instance, spring harvests in Arizona are primarily scheduled to end before most females abandon winter dens, therefore spring harvests are dominated by males. Moreover, spring harvests account for $<10$ percent of the total annual take. 
Table 1. Time period and number (proportion) of black bears taken by hunting method in Arizona.

\begin{tabular}{ccc}
\hline \multirow{2}{*}{ Time period } & \multicolumn{2}{c}{ Number (proportion) of harvested black bears } \\
\cline { 2 - 3 } & By boot hunters & By hound hunters \\
\hline $1981-1990$ & $2003(0.818)$ & $447(0.182)$ \\
$1991-2000$ & $1650(0.820)$ & $363(0.180)$ \\
$2001-2011$ & $1927(0.762)$ & $603(0.238)$ \\
\hline$X^{2}=32.285, \mathrm{df}=2, P<0.001$
\end{tabular}

Table 2. Time period and number (proportion) of female black bears taken by hunting method in Arizona.

\begin{tabular}{ccc}
\hline \multirow{2}{*}{ Time period } & \multicolumn{2}{c}{$\begin{array}{c}\text { Number (proportion) of } \\
\text { female black bears harvested }\end{array}$} \\
\cline { 2 - 3 } & By boot hunters & By hound hunters \\
\hline $1981-1990$ & $777(0.816)$ & $175(0.184)$ \\
$1991-2000$ & $673(0.811)$ & $157(0.189)$ \\
$2001-2011$ & $684(0.748)$ & $231(0.252)$ \\
\hline
\end{tabular}

$X^{2}=15.892, \mathrm{df}=2, P<0.001$

Table 3. Time period and number (proportion) of male and female black bears harvested by all methods in Arizona.

\begin{tabular}{ccc}
\hline \multirow{2}{*}{ Time period } & \multicolumn{2}{c}{ Number (proportion) of black bears harvested } \\
\cline { 2 - 3 } & Male & Female \\
\hline $1981-1990$ & $1417(0.598)$ & $952(0.402)$ \\
$1991-2000$ & $1166(0.584)$ & $830(0.416)$ \\
$2001-2011$ & $1583(0.634)$ & $914(0.366)$ \\
\hline
\end{tabular}

$X^{2}=12.75, \mathrm{df}=2, P<0.005$

Table 4. Time period and number (proportion) of male and female black bears harvested by hound hunters in Arizona.

\begin{tabular}{ccc}
\hline \multirow{2}{*}{ Time period } & \multicolumn{2}{c}{$\begin{array}{c}\text { Uumber (proportion) of black bears } \\
\text { harvested by hound hunters }\end{array}$} \\
\cline { 2 - 3 } & Male & Female \\
\hline $1981-1990$ & $269(0.606)$ & $175(0.394)$ \\
$1991-2000$ & $206(0.567)$ & $157(0.433)$ \\
$2001-2011$ & $373(0.618)$ & $231(0.382)$ \\
\hline$X^{2}=2.433, \mathrm{df}=2, \mathrm{NS}$ & &
\end{tabular}

Table 5. Time period and number (proportion) of male and female black bears harvested by boot hunters in Arizona.

\begin{tabular}{ccc}
\hline \multirow{2}{*}{ Time period } & \multicolumn{2}{c}{$\begin{array}{c}\text { Number (proportion) of black bears } \\
\text { harvested by boot hunters }\end{array}$} \\
\cline { 2 - 3 } & Males & Females \\
\hline $1981-1990$ & $1148(0.596)$ & $777(0.404)$ \\
$1991-2000$ & $960(0.588)$ & $673(0.412)$ \\
$2001-2011$ & $1210(0.639)$ & $684(0.361)$ \\
\hline$X^{2}=11.435, \mathrm{df}=2, P<0.005$
\end{tabular}

Table 6. Time period and mean age of harvested female black bears by hunting method in Arizona.

\begin{tabular}{ccc}
\hline \multirow{2}{*}{ Time period } & \multicolumn{2}{c}{ Mean age of female black bears harvested } \\
\cline { 2 - 3 } & By boot hunters & By hound hunters \\
\hline $1981-1990$ & 5.3 & 5.7 \\
$1991-2000$ & 6.1 & 6.4 \\
$2001-2011$ & 6.1 & 6.2 \\
\hline
\end{tabular}

Table 7. Time period and mean age of harvested male black bears by hunting method in Arizona.

\begin{tabular}{ccc}
\hline \multirow{2}{*}{ Time period } & \multicolumn{2}{c}{ Mean age of male black bears harvested } \\
\cline { 2 - 3 } & By boot hunters & By hound hunters \\
\hline $1981-1990$ & 4.4 & 4.9 \\
$1991-2000$ & 4.9 & 4.5 \\
$2001-2011$ & 5.4 & 5.1 \\
\hline
\end{tabular}

Table 8. Mean black bear age by sex and method of take in Arizona, 1981-2011.

\begin{tabular}{lcc}
\hline Method of take & Male & Female \\
\hline Hound hunting & $4.7^{\mathrm{a}}$ & $6.5^{\mathrm{b}}$ \\
Boot hunting & $4.6^{\mathrm{a}}$ & $5.7^{\mathrm{b}}$ \\
\hline$P<0.001,3 \mathrm{df}, F=28.03$ & \\
${ }^{\mathrm{a}, \mathrm{b}}$ Means with the same letter do not differ using Tukey's HSD at $P=0.05$
\end{tabular}


Although current data do not suggest that Arizona black bear harvests are excessive, should more conservative harvests ever become necessary, I see no evidence to suggest that boot hunters or hound hunters are more selective. Boot hunters seem to consistently harvest greater proportions of males than do hound hunters, although not on a biologically meaningful scale. Consequently, restricting one method over another is unlikely to be effective. The preponderance of males in the harvest and the younger age of harvested male black bears are both likely tied to the greater home ranges and movements of male black bears when compared with female black bears (Bunnell and Tait, 1985; LeCount and Yarchin, 1990), and hence their greater vulnerability. Harvests may best be reduced, if needed, by shortening seasons or structuring dates to occur when females are likely to be in dens.

\section{Acknowledgments}

I would like to thank Frances Peck for frequent queries into historical databases to provide for the necessary analyses. Amber Munig, Larissa Harding, and Kirby Bristow provided useful reviews that improved the analyses and manuscript; errors that remain are my own.

\section{References Cited}

Atwood, T.C., Young, J.K., Beckmann, J.P., Breck, S.W., Fike, J., Rhodes, O.E., Jr., and Bristow, K.D., 2011, Modeling connectivity of black bears in a desert sky island archipelago: Biological Conservation, v. 144, no. 12, p. 2851-2862, accessed September 5, 2013, at http://dx.doi.org/10.1016/j. biocon.2011.08.002.

Bunnell, F.L., and Tait, D.E.N., 1985, Mortality rates of North American bears: Artic Institute of North America, v. 38, no. 4, p. 316-323, http://dx.doi.org/10.14430/arctic2151.

Cunningham, S., and Wakeling, B.F., 2011, Black bear, in McKinney, T., deVos, J.C., Jr., and Wakeling, B.F., eds., Mammalian predators in Arizona: Phoenix, Arizona Game and Fish Department, p. 5-28.
Dimmick, R.W., and Pelton, M.R., 1996, Criteria of sex and age, in Bookhout, T.A., ed., Research and management techniques for wildlife and habitats (5th ed.): Bethesda, Md., The Wildlife Society, p. 169-214.

LeCount, A.L., 1982, Characteristics of a central Arizona black bear population: The Journal of Wildlife Management, v. 46, no. 4, p. 861-868, http://www.jstor.org/ stable/3808218.

LeCount, A.L., 1987, Characteristics of a northern Arizona black bear population-Final report: Phoenix, Arizona Game and Fish Department, Federal Aid in Wildlife Restoration, project W-76-R, $26 \mathrm{p}$.

LeCount, A.L., 1990, Characteristics of an east-central Arizona black bear population: Arizona Game and Fish Department, Technical Report 2, 32 p., http://www.azgfd. gov/w_c/documents/TR2CHARACTERISTICSOFANEASTCENTRALARIZONABLACKBEARPOPULATION.pdf.

LeCount, A.L., and Yarchin, J.C., 1990, Black bear habitat use in east-central Arizona-A final report: Arizona Game and Fish Department, Federal Aid in Wildlife Restoration Project, project W-78-R, Technical Report 4, 42 p., http:// www.azgfd.gov/w_c/documents/TR4BLACKBEARHABITATUSEINEASTC̄ENTRALARIZONA.pdf.

Wakeling, B.F., Day, R.L., Munig, A.A., and Childs, J.L., 2015, Age and sex composition of harvest and timing of birth frequency for Arizona mountain lions, in Huenneke, L.F., van Riper, C., and Hays-Gilpin, K.A., eds., The Colorado Plateau VI-Science and management at the landscape scale: Tucson, Univerisity of Arizona Press, p. 95-101, http://muse.jhu.edu/ books $/ 9780816502356$ ?auth $=0$.

Zar, J.H., 1984, Biostatistical analysis (2d ed.): Englewood Cliffs, N.J., Prentice-Hall, Inc., 718 p.

Zornes, M.L., Barber, S.P., and Wakeling, B.F., 2006, Harvest methods and hunter selectivity of mountain lions in Arizona, in Cain, J.W., III, and Krausman, P.R., eds., Managing wildlife in the southwest: Tucson, Ariz, Southwest Section of the Wildlife Society, p. 85-89. 


\title{
Visitor-Use Impacts and Habitat Associations of the Avifauna Occupying the Colorado River Corridor in Grand Canyon National Park
}

\author{
By Valerie J. Horncastle, ${ }^{1}$ Brett G. Dickson, ${ }^{1,2}$ and Todd A. Chaudhry ${ }^{3}$
}

\section{Abstract}

The 2006 Colorado River Management Plan (CRMP) is a visitor-use management plan that specifies actions to conserve natural and cultural resources, while enhancing visitor experience and river running recreational opportunities along the Colorado River in Grand Canyon National Park (GCNP). We examined the effects of the 2006 CRMP visitor use limits on the avifaunal community by analyzing monitoring data collected from 2007 to 2011. To answer key management questions, we used occupancy estimation techniques to quantify relations among avian species or guilds and multiple habitat and environmental variables. In addition, we used communitylevel estimators to quantify relations with different hydrological zones, use levels, and control and campsite locations. A total of 615 point-count surveys were conducted, and 72 species from 10 different dietary guilds were detected. Although numerous species were detected, only four species and two guilds had a sufficient number of detections to generate reliable estimates of occupancy. Blue-gray gnatcatcher (Polioptila caerulea) and black-chinned hummingbird (Archilochus alexandri) exhibited higher occupancy downstream, whereas Bewick's wren (Thryomanes bewickii) exhibited lower occupancy. Geomorphic reach was a common, strong predictor of high occupancy for these species. Total vegetation volume also influenced occupancy, with higher rates associated with greater vegetation volume for both the blue-gray gnatcatcher and yellow-breasted chat (Icteria virens). Campsite use level did not appear to influence occupancy for any of the species or guilds we evaluated. Patterns of avian richness and diversity were significantly different across visitor-use levels and hydrological zones, and total vegetation volume was a positive predictor of species richness. Relative abundance of omnivores and insect aerial foragers was greater in campsites compared to control

\footnotetext{
${ }^{1}$ Landscape Conservation Initiative, Northern Arizona University

${ }^{2}$ Conservation Science Partners

${ }^{3}$ Colorado Plateau Cooperative Ecosystem Studies Unit, National Park Service-Intermountain Region
}

sites, whereas nectivores were less abundant at campsites. Our results can be used to inform and update the CRMP and assist in guiding future management actions related to river visitor use activities and the conservation of natural resources in GCNP.

\section{Introduction}

Throughout the Southwestern United States, riparian areas support a disproportionately high density and diversity of bird species compared to adjacent nonriparian habitats (Rosenberg and others, 1982). Although riparian areas comprise less than 1 percent of the Western landscape (Knopf and others, 1988) they provide critical resources for both breeding and migrating birds (Skagen and others, 1998). Southwestern riparian woodlands may support as many as 10 times the number of bird species per hectare when compared to adjacent upland habitats primarily due to greater availability of food and cover (Szaro and Jakle, 1985). The Colorado River corridor through the Grand Canyon, in particular, provides important habitat for wintering, migrant, and breeding birds (Spence, 2006).

Grand Canyon National Park (GCNP) is a popular tourist area and visitor-use effects (recreational, research, and administrative) from backpackers and boat trips on the river are potentially influencing individual species, as well as decreasing overall avifaunal community structure. Usually as a result of direct disturbance or noise, human presence has been shown to reduce richness and abundance of avifauna (Fernández-Juricic, 2000; Schlesinger and others, 2008). In addition, visitor use at campsites along the river corridor can lead to increased trash, trails, and damage and loss of vegetation, thereby affecting avifaunal species (Zachmann and others, 2012). Several studies have documented mixed effects of pedestrians and trails on avifaunal communities, with species and guilds varying in their sensitivity to this type of disturbance (Fernández-Juricic, 2000; Miller and Hobbs, 2000; Miller and others, 2003).

GCNP developed the Colorado River Management Plan (CRMP) (National Park Service, 2006) which specifies 
actions to conserve natural and cultural resources, as well as visitor experience in GCNP, while enhancing riverrunning recreational opportunities on the Colorado River. To determine and address effects of the CRMP visitor-use limits and launch patterns on park resources, the National Park Service developed a Research, Monitoring, and Mitigation Program (RM\&MP). The key objectives of the RM\&MP were to determine the status and trends of key resources (that is, vegetation, soil, recreation, and avifauna), identify and understand meaningful resource condition changes associated with river use, identify appropriate mitigation and management actions, and assess the efficacy of such actions within an adaptive management framework (National Park Service, 2006).

The primary goal of this project was to analyze and interpret avifaunal data collected from 2007 to 2011 to answer the park's key management questions. General management questions included whether species occupancy, community richness, and diversity were negatively associated with visitoruse level. Specifically, our research had three main objectives(1) estimate annual occupancy and detection probabilities for avifaunal species and guilds and relate these parameters to several different habitat, environmental, or detection variables, (2) estimate and compare avifaunal community parameters (that is, diversity and richness) among different hydrological zones and visitor-use levels, and (3) compare relative abundance (bird counts) between campsites and control sites for general bird groups (that is, residents, nonresidents, and guilds) when occupancy modeling was not possible. Specifically, we addressed whether riparian nesting-bird species, nonresidents, and different dietary guilds had higher relative abundance at control sites versus campsites. For community metrics, we predict greater species richness and diversity at control sites versus high-use campsites. We hypothesize that different dietary guilds would respond differently to visitor use. Specifically, we predict that ground and foliage insectivorous and omnivorous species would have greater abundance at campsites compared to control sites as a result of an increase in forage (that is, food scraps and ants), whereas nectivores would have lower abundance.

\section{Methods}

\section{Study Area}

The Colorado River in GCNP flows 478 kilometers $(\mathrm{km})$ through Arizona, starting in the northeast corner of the park downstream of Glen Canyon Dam and stretching westward to Lake Mead. The elevation of the river drops a total of 590 meters (m) from the dam (955 m) to Lake Mead (365 m). Dominant vegetation communities range from Great Basin desert scrub at the upper reaches of the Colorado River to a Sonoran desert scrub at the lower reaches. The post-dam vegetation zone, or new high-water zone (NHWZ), adjacent to the river consists mostly of tamarisk (Tamarix chinensis), coyote willow (Salix exigua), rushes and grasses. The pre-dam vegetation zone, or old high-water zone (OHWZ), consists of a variety of species, including Apache plume (Fallugia paradoxa), net-leaf hackberry (Celtis reticulata), mesquite (Prosopis glandulosa), and catclaw (Acacia greggii).

\section{Surveys}

Avifaunal survey sites were located between Lee's Ferry and Diamond Creek along the Colorado River corridor (fig. 1). Field crews conducted point-count surveys once a year during spring (April-May) 2007-2011 at campsites and nearby paired control sites (mean distance $=800 \mathrm{~m}$ ). To measure the effects of different levels of camping use on bird occurrence, point counts were taken in the NHWZ at each campsite and control site and in OHWZ patches at sites where they were present. One or two point counts were made at each site depending on site size. Typically, sites that had $>150 \mathrm{~m}$ of shoreline were surveyed with two point counts per zone, whereas sites $<150 \mathrm{~m}$ received only one point count. Surveys were conducted as soon as it was light enough to see a distance of at least $200 \mathrm{~m}$ and ended at no later than 10 a.m. Point counts were not conducted if wind strength was 4 or greater on the Beaufort scale or during periods of heavy rain or snow to minimize the effects of environmental variables on detectability. Each point count was conducted for a total of 10 minutes. Data were collected on all bird species observed by both auditory and visual cues, and distances to detections were estimated within three distance categories $(<25 \mathrm{~m}, 25-50 \mathrm{~m}$, $>50 \mathrm{~m}$ ). Estimates of total vegetation volume also were measured at all bird point-count locations, including campsites and control sites, following Mills and others (1991).

\section{Analyses}

Few efforts have been made to inventory avifauna in GCNP that would also permit statistical estimation of key population parameters. Thus, we attempted to take advantage of a survey effort that could permit statistical inferences about avifaunal populations occupying the Colorado River corridor. The CRMP avifaunal sampling effort and associated data analysis described here was originally designed within a distance-based framework (Buckland and others, 2001). However, the sampling protocol recorded all audio and visual observations whether or not they were on site or off site; therefore, we dropped all observations $>50 \mathrm{~m}$ from the analysis to reduce the possibility of including off-site observations in the site-level analysis. With only two effective distance categories, $(<25 \mathrm{~m}, 25-50 \mathrm{~m})$, we could not reliably estimate a detection probability for each species using program DISTANCE (Thomas and others, 2010). After discussions with GCNP staff and ecological statistician D. MacKenzie (oral commun., 2012), we determined the avifaunal data would 
be more amenable to an occupancy-modeling framework using a spatial replication approach (MacKenzie and others, 2006). A multiseason occupancy modeling approach permits simultaneous estimation of detection probability and occupancy, as well as colonization and local extinction rates (MacKenzie and others, 2003). In addition, occupancy models that account for imperfect detection and include covariates can be less biased than models that disregard imperfect detection and improve estimates by accounting for among-site variation (MacKenzie and others, 2004; Guillera-Arroita and others, 2014). It is important to note that a spatially replicated sampling approach (without replacement) can be vulnerable to positive bias in occupancy estimators when some individual sampling locations are unoccupied at the time of sampling (Kendall and White, 2009; Guillera-Arroita, 2011). Because many of our species were highly mobile and samples were collected sequentially, some of this bias may have been mitigated (Kendall and White, 2009; Guillera-Arroita, 2011).
Our survey sites were only $150 \mathrm{~m}$ apart, whereas several of the bird species in our study area typically have home ranges varying from 0.4 to 1.6 hectares (ha) (Schoener, 1968). We acknowledge that some of these species could have moved between or among survey sites, although observers attempted to minimize the influence of this behavior on their surveys.

\section{Occupancy Estimates}

We used a "spatial replication" approach, where the second point count done at some of the campsites was treated as the "repeat survey," providing two surveys per year for some of the sites (MacKenzie and others, 2006). If a site did not have a second point count, it was considered to have a missed (second) visit. Occupancy models were run for each species and guild for which we had sufficient data. Sites with only 1 year of detection data or without measurement of habitat variables were excluded from our analysis.

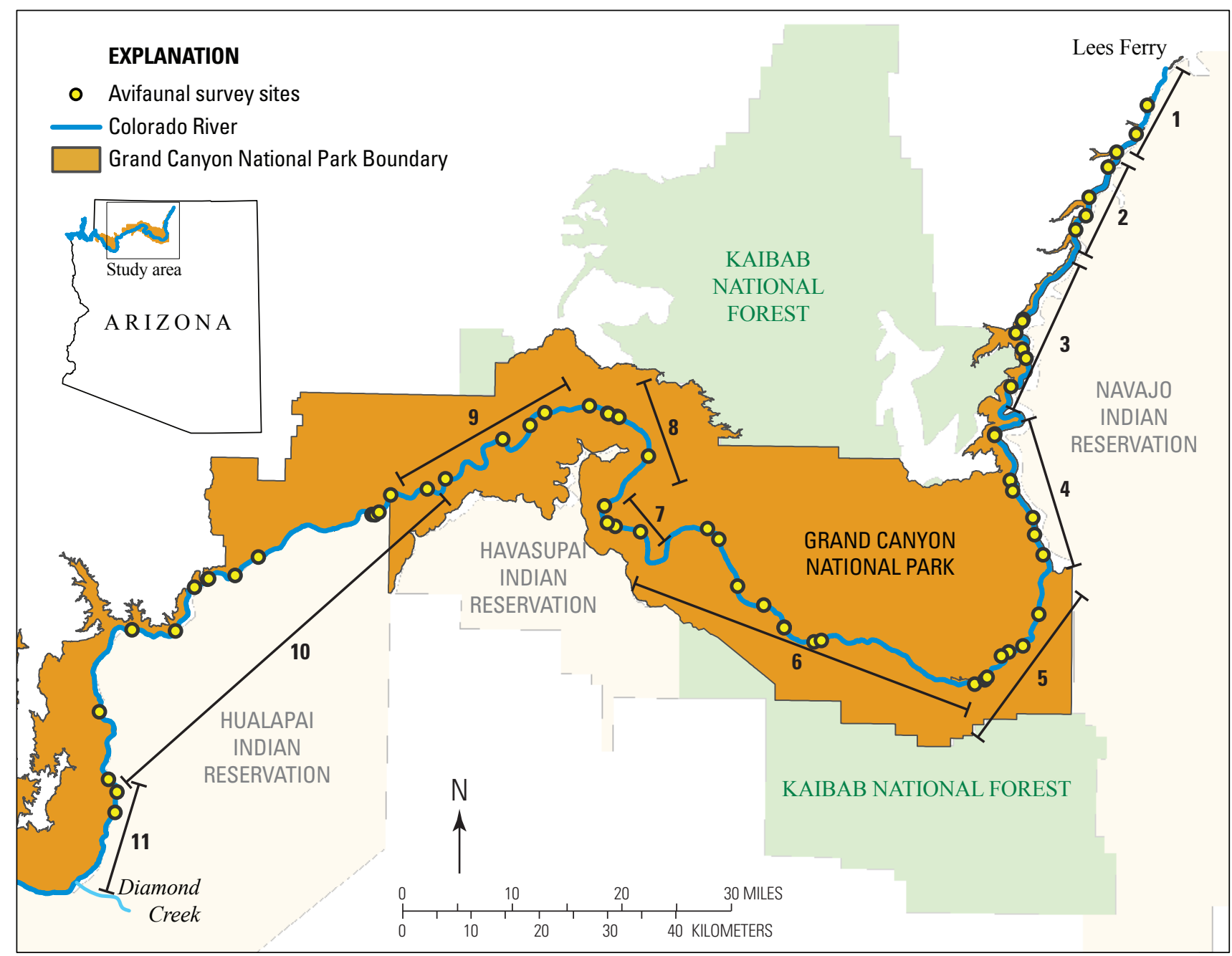

Figure 1. Map showing locations of all campsites sampled under the National Park Service Research, Monitoring, and Mitigation Program avifaunal surveys in Grand Canyon National Park, Arizona, 2007-2011. Geomorphic reaches of the Colorado River below Lees Ferry (1-11) are denoted with brackets and labeled. Note that not every site was sampled in every year of the monitoring program. 
Table 1. Description of response variables used in the analysis of the 2007-2011 avifaunal data in Grand Canyon National Park, Arizona.

[Variables are denoted as $(\psi)$ if they were used to describe occupancy and (p) for detectability in the models. Cfs, cubic feet per second; m, meters]

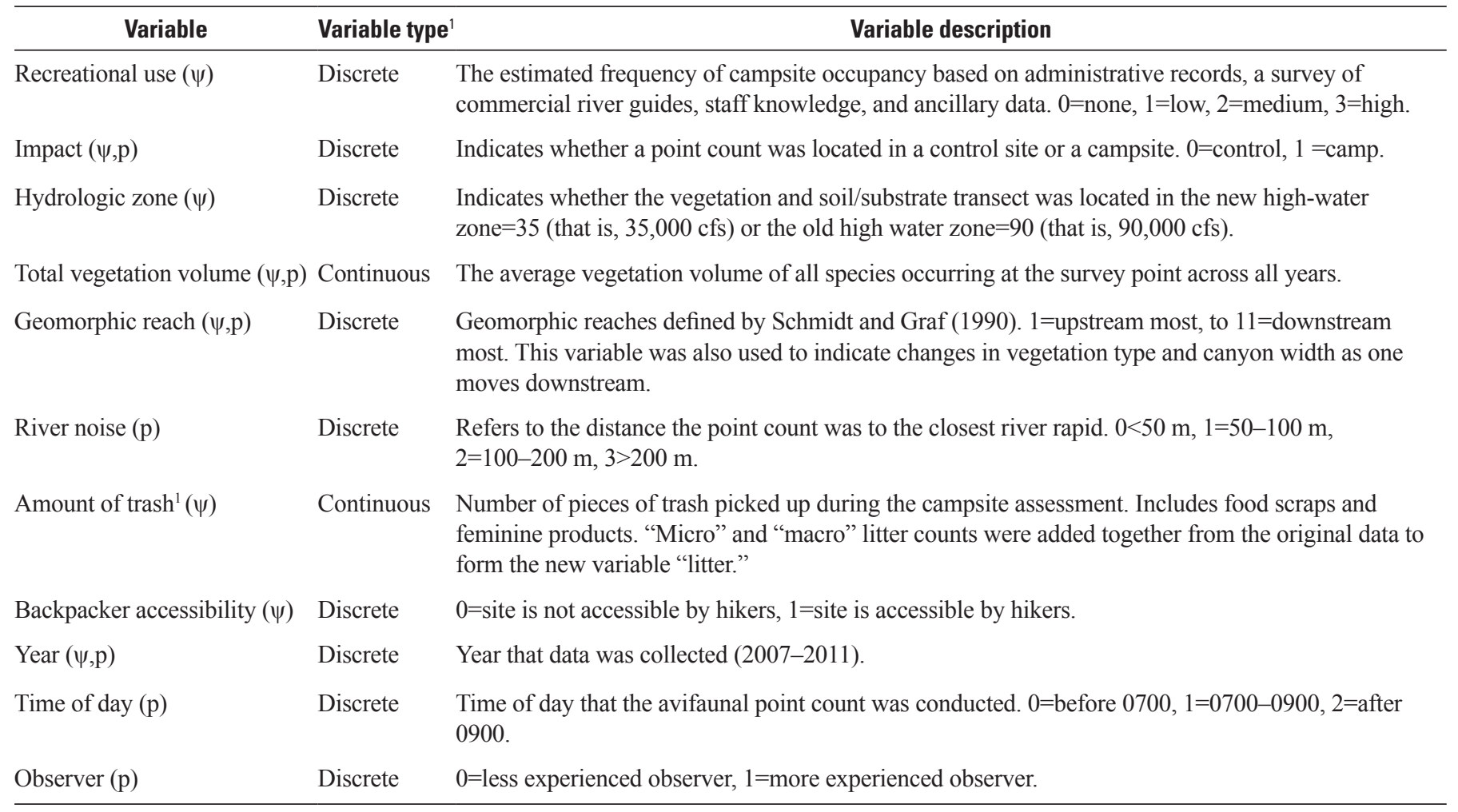

${ }^{1}$ Variables were treated as a continuous predictor variable in the occupancy modeling and the variable importance modeling.

We used nine covariates of occupancy or detectionvisitor-use level ("control," low, moderate, and high), impact (control and campsite), hydrologic zone (OHWZ and NHWZ), total vegetation volume, river noise (distance to rapids), amount of trash, backpacker accessibility, geomorphic reach, and year (table 1). Although vegetation data were collected during each survey, we considered it a site-specific variable as opposed to a survey-specific variable, because vegetation data were not collected in 2011 or in the same location each year. For each site, we calculated the average total vegetation volume across all years and used this value in our modeling. Survey-specific variables included observer and time of day and were hypothesized to influence detectability. Observer performance varies among and within individuals and is strongly influenced by training, experience, hearing acuity, eyesight, and motivation (Rosenstock and others, 2002). To account for some of this variability, a survey was sent to all observers that rated the experience level (less experience versus more experience) of the other observers. Time of day can affect detectability because the singing rate for most species is usually highest before or near official sunrise and then declines slowly for the next 4 hours. Therefore, we included a three-category covariate for time of day in our models (before 7 a.m., 7-9 a.m., and after 9 a.m.).
For each species and guild with sufficient total detections (typically $>50$ ) we fit multiseason occupancy models in program PRESENCE, version 4.1 (Hines, 2006). We derived estimates of occupancy for 2007, the initial year of the study, and year-specific estimates for 2008-2011 by modeling probabilities of colonization and local extinction (MacKenzie and others, 2003). For species without enough detections to run multiseason analysis (typically $>30$ and $<80$ detections), we used the single-season occupancy estimation feature in program PRESENCE, version 4.1 (Hines, 2006), but pooled detections across years for each site. For both the multiseason and single-season analyses, we derived estimates for each parameter separately based on "global" models that simultaneously included the most parsimonious model for the other parameters (Dickson and others, 2009). We used Akaike's Information Criterion (AIC) (Burnham and Anderson, 2002) to identify the "best" model(s) among a candidate set of nested models that each represented a priori-determined combinations of the variables defined above. We considered candidate models with AIC difference ( $\triangle \mathrm{AIC}$ ) values $<4.0$ as those that best approximated the data. We also included null models of occupancy and detection probability (denoted by "dot" models) within each candidate set to evaluate the performance (and fit) of the best model(s) (Anderson, 2008). These null models held 
occupancy, colonization, extinction and detectability constant across sites and surveys.

We computed model-averaged parameter estimates and unconditional standard errors for variables included in models with $\triangle$ AIC values $<4.0$ (Burnham and Anderson, 2002). Using model-averaged regression estimates and unconditional standard errors, we computed a $Z$-statistic to estimate the magnitude and rank the relative importance of each variable (Gotelli and Ellison, 2004). We considered absolute values of $Z>2.0$ to be indicative of a reasonably strong predictor variable. Because we used an information-theoretic approach to model selection and model-based inference, we did not compute $p$-values.

Before implementing our occupancy models, we computed a Spearman correlation coefficient to determine if univariate correlations between continuous variables were present or problematic (that is, $>0.70$ ). Because no variables had a correlation coefficient $>0.30$, none were eliminated from our analyses.

\section{Community Estimates}

We used EstimateS (Colwell, 2006) to calculate estimates of avifaunal diversity and richness for each hydrological zone, use level, year, and type of site (control site versus campsite). Lande and others (2000) recommend that a measure of Simpson diversity, as well as species richness, should be used when comparing communities to account for discontinuities in evenness amongst assemblages. For simplicity, we only report and discuss the results for Simpson diversity and the jackknife (Jack1) richness estimator (Burnham and Overton, 1978, 1979). We chose the Simpson's index because its performance is well understood, it is intuitively meaningful, and it is one of the most robust diversity measures available (Magurran, 2004). Simpson's index provides a good estimate of diversity at relatively small sample sizes and will rank assemblages consistently. The jackknife richness estimator was selected because it has been found to be least biased for smaller sample sizes (Palmer, 1990; Hellmann and Fowler, 1999) and also accommodates data on abundance (Gotelli and Colwell, 2011).

We used Welch's $t$-test (test statistic $=t, \alpha=0.05$ ) (Ruxton, 2006) to statistically compare and contrast differences in diversity and richness among hydrologic zones, control sites and campsites, and use levels, because it allowed us to compare samples with unequal variance. There were relatively few sites in our dataset that were categorized as high or moderate use levels, so these categories were combined to increase sample size and are labeled as high use in our results below. High use and low use were each compared to no-use sites. A oneway ANOVA (test statistic $=F, \alpha=0.05$ ) (Kruskal and Wallis, 1952) was also used to test for differences in diversity and richness among all 5 years. If the ANOVA indicated significant differences among years, a Tukey (HSD) test (test statistic $=q$, $\alpha=0.05$ ) was used to determine which years were significantly different from others (Tukey, 1953; Kramer, 1956). We used a linear mixed model to evaluate the relation between observed species richness and total vegetation volume for transects $(n=115)$ located within camp or control sites. We treated the interaction between site $(n=39)$ and site type (control versus camp) as a subject-level (nested) random effect and total vegetation volume (standardized and rescaled) as a fixed effect. Because the true covariance structure in our response variable (observed rather than estimated species richness) was not known, we used an empirically based method to calculate the standard errors of the fixed effect parameters (Williams, 2000). We evaluated model fit and performance using AIC and, by convention, considered a $\triangle \mathrm{AIC}$ value between our model and an intercept-only (that is, null) model of $>4.0$ to be acceptable for inference (Anderson, 2008). We determined statistical significance of total vegetation volume variable using a twotailed $t$-test (test statistic $=t, \alpha=0.05$ ). We implemented these models using the MIXED procedure in SAS (version 9.2, SAS Institute, Inc., Cary, North Carolina).

To address our third objective, we used a Wilcoxon signed rank test for paired data (Wilcoxon, 1945; test statistic $=Z$, $\alpha=0.05$ ) to test for differences in relative abundance between camp and control sites for different guilds, riparian nesting bird species, and resident bird species. We paired camp and control samples within the same site and year such that a given site could be represented by as many as five paired samples, resulting in 334 paired samples for the 153 sites. This analysis was limited to guilds or groups that had $>10$ detections.

\section{Results}

A total of 615 point counts were conducted from 2007 2011 along the Colorado River in GCNP, with the greatest number of counts $(n=131)$ in 2009 and the fewest $(n=114)$ in 2011. Seventy-two species from 10 different dietary guilds were detected. The most common species were blue-gray gnatcatcher (Polioptila caerulea), common yellowthroat (Geothlypis trichas), house finch (Carpodacus mexicanus), Lucy's warbler (Oreothlypis luciae), and yellow warbler (Dendroica petechia) (appendix A).

\section{Occupancy Estimates}

Among the 153 sites sampled, only 48 of these sites received two point counts in a given year. Although we lacked sufficient data to model occupancy for most species detected in the river corridor, we were able to implement multiseason occupancy models for 3 species and 2 avifaunal dietary guilds (table 2) - black-chinned hummingbird (Archilochus alexandri), Bewick's wren (Thryomanes bewickii), blue-gray gnatcatcher (Polioptila caerulea), the nectivore guild, and the seed groundforager guild. The number of detections for species varied with blue-gray gnatcatcher having the most detections (160), followed by black-chinned hummingbird (82), and Bewick's wren (58). For black-chinned hummingbird and Bewick's wren, the best occupancy model included geomorphic reach and hydrologic zone (table 2). For both species, geomorphic reach was the 
Table 2. Multiseason occupancy model selection results for two avifaunal dietary guilds and three species in Grand Canyon National Park, Arizona, 2007-2011.

[We considered candidate models with Akaike's Information Criterion difference ( $\triangle \mathrm{AIC}$ ) values $<4.0$ as those that best approximated the data. Modeled effects include use level $(n=4 ; \mathrm{U})$, year $(n=5$; Y), impact (campsite versus control; I), zone (old high water zone versus new high water zone; Z), noise (distance to rapids; N), total vegetation volume $(\mathrm{V})$, amount of trash $(\mathrm{T})$, reach number $(\mathrm{R})$, backpacker site $(\mathrm{H})$, time $(\mathrm{TM})$, and observer $(\mathrm{O})$. Constant model denoted by "dot." Models that did not converge are not presented and were not used for inference. See appendix A for scientific species names]

\begin{tabular}{|c|c|c|c|c|c|c|c|c|c|}
\hline Model & $-2 \Gamma$ & $\boldsymbol{k}^{2}$ & $\Delta \mathbf{A I C}^{3}$ & $w^{4}$ & Model & $-2 \Gamma$ & $\boldsymbol{k}^{2}$ & $\Delta \mathbf{A I C}^{3}$ & $w^{4}$ \\
\hline \multicolumn{5}{|c|}{ Nectivore $^{5}$} & \multicolumn{5}{|c|}{ Bewick's wren $^{8}$} \\
\hline$\Psi(\mathrm{R}, \mathrm{Z})$ & 498.75 & 19 & 0 & 0.485 & $\Psi(\mathrm{Z}, \mathrm{R})$ & 302.93 & 13 & 0 & 0.467 \\
\hline$\Psi(\mathrm{R}, \mathrm{Z}, \mathrm{V})$ & 498.04 & 20 & 1.29 & 0.255 & $\Psi(\mathrm{R})$ & 306.43 & 12 & 1.50 & 0.221 \\
\hline$\Psi(\mathrm{R}, \mathrm{Z}, \mathrm{V}, \mathrm{U})$ & 497.68 & 21 & 2.93 & 0.112 & $\Psi(\mathrm{Z}, \mathrm{V}, \mathrm{R})$ & 302.47 & 14 & 1.54 & 0.216 \\
\hline$\Psi(\mathrm{R})$ & 506.01 & 18 & 5.26 & 0.035 & $\Psi(\mathrm{U}, \mathrm{Z}, \mathrm{V}, \mathrm{R}, \mathrm{H})$ & 303.15 & 16 & 6.22 & 0.021 \\
\hline$\Psi(\mathrm{R}, \mathrm{Z}, \mathrm{V}, \mathrm{U}, \mathrm{I}, \mathrm{T})$ & 496.20 & 23 & 5.45 & 0.032 & $\Psi(\mathrm{U}, \mathrm{Z}, \mathrm{V}, \mathrm{T}, \mathrm{R}, \mathrm{H})$ & 301.37 & 17 & 6.44 & 0.019 \\
\hline$\Psi()$. & 522.32 & 17 & 19.57 & 0 & $\Psi()$. & 329.69 & 11 & 22.76 & 0 \\
\hline \multicolumn{5}{|c|}{ Seed ground forager ${ }^{6}$} & \multicolumn{5}{|c|}{ Blue-gray gnatcatcher ${ }^{9}$} \\
\hline$\Psi(\mathrm{U}, \mathrm{I}, \mathrm{Z}, \mathrm{T}, \mathrm{H})$ & 665.94 & 16 & 1.78 & 0.166 & $\Psi(\mathrm{V}, \mathrm{R})$ & 556.42 & 19 & 2.68 & 0.112 \\
\hline$\Psi(\mathrm{U}, \mathrm{I}, \mathrm{Z}, \mathrm{T}, \mathrm{H}, \mathrm{V})$ & 665.56 & 17 & 3.40 & 0.074 & $\Psi(\mathrm{U}, \mathrm{V}, \mathrm{R}, \mathrm{I}, \mathrm{H})$ & 550.73 & 22 & 2.99 & 0.096 \\
\hline$\Psi(\mathrm{U}, \mathrm{I}, \mathrm{Z}, \mathrm{T}, \mathrm{H}, \mathrm{V}, \mathrm{R})$ & 664.25 & 18 & 4.09 & 0.052 & $\Psi(\mathrm{U}, \mathrm{V}, \mathrm{R}, \mathrm{I}, \mathrm{H}, \mathrm{T})$ & 549.60 & 23 & 3.86 & 0.062 \\
\hline$\Psi(\mathrm{U}, \mathrm{Z})$ & 675.13 & 13 & 4.97 & 0.034 & $\Psi(\mathrm{R})$ & 560.67 & 18 & 4.93 & 0.037 \\
\hline$\Psi(U)$ & 677.19 & 12 & 5.03 & 0.033 & $\Psi()$. & 582.73 & 17 & 24.99 & 0 \\
\hline
\end{tabular}

\begin{tabular}{lcccc}
$\Psi()$. & 679.40 & 11 & 5.24 & 0.073 \\
\hline$\Psi(\mathrm{R}, \mathrm{Z})$ & \multicolumn{1}{c}{ Black-chinned hummingbird7 } & \\
$\Psi(\mathrm{R}, \mathrm{Z}, \mathrm{V})$ & 404.43 & 17 & 0 & 0.412 \\
$\Psi(\mathrm{R}, \mathrm{Z}, \mathrm{V}, \mathrm{U})$ & 403.06 & 18 & 0.63 & 0.301 \\
$\Psi(\mathrm{R})$ & 402.79 & 19 & 2.36 & 0.127 \\
$\Psi(\mathrm{R}, \mathrm{Z}, \mathrm{V}, \mathrm{U}, \mathrm{I})$ & 409.38 & 16 & 2.95 & 0.094 \\
$\Psi(\mathrm{R}, \mathrm{Z}, \mathrm{V}, \mathrm{U}, \mathrm{I}, \mathrm{T})$ & 402.72 & 20 & 4.29 & 0.048 \\
$\Psi()$. & 402.72 & 21 & 6.29 & 0.018 \\
\hline & 423.17 & 15 & 14.74 & 0.001 \\
\hline
\end{tabular}

\footnotetext{
${ }^{1}$ Twice the negative log-likelihood value.

${ }^{2}$ Total number of model parameters.

${ }^{3} \mathrm{AIC}$ difference value.

${ }^{4} \mathrm{AIC}$ model weight.

${ }^{5} \gamma(\mathrm{U}, \mathrm{I}, \mathrm{V}, \mathrm{R}) \varepsilon(\mathrm{V}, \mathrm{R}) p(\mathrm{Y}, \mathrm{V}, \mathrm{R}, \mathrm{O})$.

${ }^{6} \gamma(\mathrm{V}) \varepsilon(\mathrm{I}) p(\mathrm{Y}, \mathrm{R})$.

${ }^{7} \gamma(\mathrm{V}, \mathrm{R}) \varepsilon(\mathrm{V}) p(\mathrm{Y}, \mathrm{I}, \mathrm{N}, \mathrm{R}, \mathrm{O})$.

${ }^{8} \gamma(.) \varepsilon() p.(\mathrm{Y}, \mathrm{N}, \mathrm{R}, \mathrm{O})$.

${ }^{9} \gamma(\mathrm{I}, \mathrm{R}, \mathrm{Z}) \varepsilon(\mathrm{I}, \mathrm{Z}, \mathrm{V}, \mathrm{T}, \mathrm{H}) p(\mathrm{I}, \mathrm{V}, \mathrm{R}, \mathrm{TM}, \mathrm{O})$.
}

best predictor of occupancy (table 3), with black-chinned hummingbird and Bewick's wren positively and negatively associated with geomorphic reach, respectively. Annual estimates of occupancy for black-chinned hummingbird were relatively constant during 2007-2011, ranging from 0.48 to 0.57 (fig. 2). Candidate model results and estimates for black-chinned hummingbird were similar to the nectivore guild, because detections within this guild consisted mostly of this one species. There were only two other species - broad-tailed hummingbird (Selasphorus platycercus) and Costa's hummingbird (Calypte costae) — in this guild and they had less than 14 detections each. Annual estimates for Bewick's wren were more variable. Years 2007, 2008, 2010, and 2011 produced relatively low estimates $(<0.33)$ and indicated a slight downward trend in occupancy, although occupancy increased (0.54) in 2009 (fig. 2). The best model for blue-gray gnatcatcher included geomorphic reach, total vegetation volume, and visitor-use level. This species was positively associated with total vegetation volume and geomorphic reach. Visitor-use level was not a strong predictor of occupancy (table 3) even though it appeared in the best model. 
Blue-gray gnatcatcher exhibited relatively low but constant annual estimates of occupancy, ranging from 0.06 to 0.08 (fig. 2), although such small estimates should be interpreted with caution.

For the nectivore guild, the best model of initial occupancy included geomorphic reach and hydrologic zone (table 2). The best predictor of occupancy for nectivores was geomorphic reach with occupancy greater downstream (table 3). Annual estimates varied across years with 2008 (0.49) and $2011(0.40)$ having lower estimates than 2007, 2009, and 2010, which had occupancy estimates between 0.6 and 0.7 (fig. 3). The best model for the seed ground forager included visitor-use level, hydrologic zone, amount of trash, and backpacker accessibility; however, none of these variables were strong predictors of occupancy. Annual estimates for the seed foraging guild peaked in the middle of the study, with lower estimates in 2007 (0.60) and 2011 (0.39) and the highest estimates in 2009 (0.76) (fig. 3).

There was only one species, yellow-breasted chat (Icteria virens), with a sufficient number of detections to produce reliable estimates of occupancy using the single-season

Table 3. Standardized model-averaged regression coefficients $(\widetilde{\bar{b}})$, unconditional standard errors (SE), and Z-statistics $(Z)$ for variables included in the best models of occupancy (2007) for two guilds and four species in Grand Canyon National Park, Arizona.

[Variables were ranked only for guilds whose best models were $>4 \triangle \mathrm{AIC}$ (Akaike's Information Criterion difference) units from the null model (tables 2 and 4 ), indicating that these variables were approximating the data well. $Z$-values $>2.0$ are indicative of reasonably strong predictor variable and denoted in bold. NE, variable was not estimable. See appendix A for scientific species names]

\begin{tabular}{|c|c|c|c|c|c|c|c|c|c|}
\hline Variable & $\widetilde{\bar{b}}$ & SE & Z & $\widetilde{\mathrm{b}}$ & SE & Z & $\widetilde{\mathrm{b}}$ & SE & Z \\
\hline & \multicolumn{3}{|c|}{ Nectivore guild } & \multicolumn{3}{|c|}{ Seed ground forager } & \multicolumn{3}{|c|}{ Blue-gray gnatcatcher } \\
\hline Hydrologic zone & -2.54 & 1.37 & 1.86 & -1.46 & 1.04 & 1.41 & $\mathrm{NE}$ & $\mathrm{NE}$ & $\mathrm{NE}$ \\
\hline Use level & 0.03 & 0.15 & 0.21 & -0.65 & 0.42 & 1.53 & 0.72 & 0.54 & 1.35 \\
\hline Vegetation volume & 0.01 & 0.003 & 0.63 & 0.001 & 0.001 & 0.43 & 0.02 & 0.005 & 2.96 \\
\hline Geomorphic reach & 0.53 & 0.15 & 3.66 & -0.005 & 0.01 & 0.45 & 0.62 & 0.14 & 4.46 \\
\hline Impact & -0.21 & 0.43 & 0.48 & 0.16 & 0.42 & 0.38 & -0.61 & 1.00 & 0.61 \\
\hline \multirow[t]{2}{*}{ Backpacker accessibility } & $\mathrm{NE}$ & $\mathrm{NE}$ & $\mathrm{NE}$ & -1.09 & 1.02 & 1.07 & 0.22 & 0.45 & 0.50 \\
\hline & \multicolumn{3}{|c|}{ Black-chinned hummingbird } & \multicolumn{3}{|c|}{ Bewick's wren } & \multicolumn{3}{|c|}{ Yellow-breasted chat } \\
\hline Hydrologic zone & -1.86 & 1.06 & 1.76 & -2.62 & 2.43 & 1.08 & -0.001 & 0.05 & 0.01 \\
\hline Use level & 0.03 & 0.12 & 0.21 & 0.01 & 0.02 & 0.25 & -0.04 & 0.09 & 0.39 \\
\hline Impact & 0.03 & 0.15 & 0.22 & $\mathrm{NE}$ & $\mathrm{NE}$ & $\mathrm{NE}$ & NE & NE & NE \\
\hline Backpacker accessibility & $\mathrm{NE}$ & $\mathrm{NE}$ & $\mathrm{NE}$ & 0.20 & 0.38 & 0.52 & $\mathrm{NE}$ & NE & $\mathrm{NE}$ \\
\hline
\end{tabular}

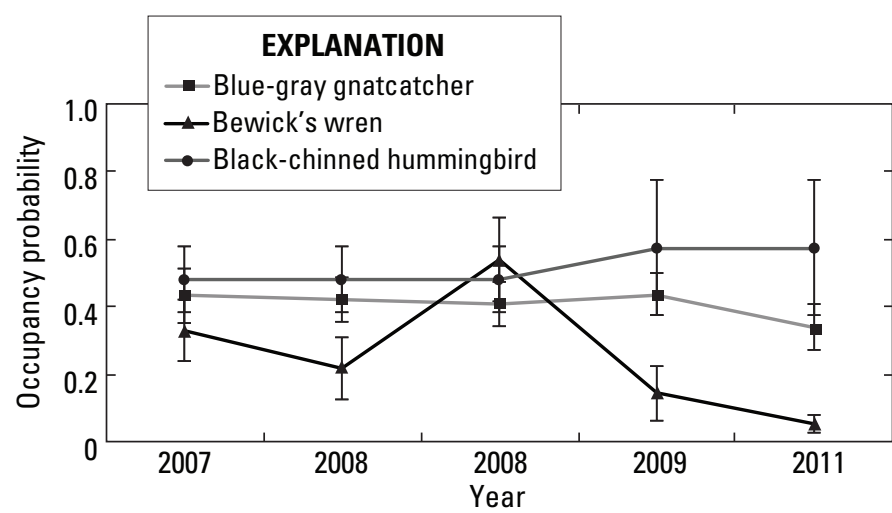

Figure 2. Graph showing annual mean ( \pm unconditional standard errors, SE; see gray vertical bars) estimates of occupancy for blue-gray gnatcatcher, Bewick's wren, and black-chinned hummingbird in Grand Canyon National Park, Arizona, 2007-2011. See appendix A for scientific species names.

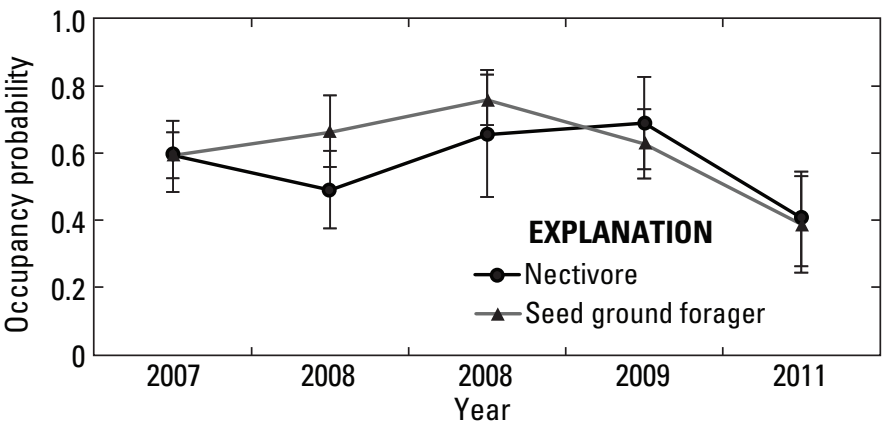

Figure 3. Graph showing annual mean ( \pm unconditional standard errors, SE; see gray vertical bars) estimates of occupancy for the nectivore and seed ground forager guilds in Grand Canyon National Park, Arizona, 2007-2011. 
Table 4. Single-season occupancy model selection results for the yellow-breasted chat (/cteria virens) detected in Grand Canyon National Park, Arizona, 2007-2011.

[We considered candidate models with Akaike's Information Criterion difference ( $\triangle \mathrm{AIC}$ ) values $<4.0$ as those that best approximated the data. Modeled effects include use level $(n=4 ; \mathrm{U})$, year $(n=5 ; \mathrm{Y})$, impact (campsite versus control; I), zone (old high water zone versus new high water zone; Z), noise (distance to rapids; $\mathrm{N}$ ), total vegetation volume $(\mathrm{V})$, amount of trash $(\mathrm{T})$, reach number $(\mathrm{R})$, backpacker site $(\mathrm{H})$, time $(\mathrm{TM})$, and observer $(\mathrm{O})$. Constant model denoted by "dot." Models that did not converge are not presented and were not used for inference]

\begin{tabular}{lllll}
\hline \multicolumn{1}{c}{ Model } & $-\mathbf{2} \boldsymbol{\Gamma}$ & $\boldsymbol{k}^{2}$ & $\Delta$ AIC $^{3}$ & $\boldsymbol{w}^{\mathbf{4}}$ \\
\hline \multicolumn{5}{c}{ Yellow-breasted chat } \\
\hline$(\mathrm{V})$ & 182.54 & 5 & 0 & 0.542 \\
$\Psi(\mathrm{V}, \mathrm{R})$ & 181.87 & 6 & 1.33 & 0.279 \\
$\Psi(\mathrm{V}, \mathrm{R}, \mathrm{U})$ & 181.43 & 7 & 2.89 & 0.128 \\
$\Psi(\mathrm{V}, \mathrm{R}, \mathrm{U}, \mathrm{Z})$ & 181.43 & 8 & 4.89 & 0.047 \\
$\Psi()$. & 193.89 & 4 & 9.35 & 0.005 \\
\hline
\end{tabular}

${ }^{1}$ Twice the negative log-likelihood value.

${ }^{2}$ Total number of model parameters.

${ }^{3}$ AIC difference value.

${ }^{4} \mathrm{AIC}$ model weight.

${ }^{5} p(\mathrm{~N}, \mathrm{TM})$.

Table 5. Wilcoxon signed rank test $(\alpha=0.05)$ comparing abundance of seven avifaunal guilds among control and campsites in Grand Canyon National Park, Arizona, 2007-2011.

[Significant values denoted in bold. Negative $Z$ values indicate a negative relation between abundance and campsite. Point counts were separated by site and year in the analysis. $P, p$-value]

\begin{tabular}{lccc}
\hline \multicolumn{1}{c}{ Guilds } & $\begin{array}{c}\text { Number of } \\
\text { sites }\end{array}$ & $Z$ & $P$ \\
\hline Insect aerial forager & 334 & 2.21 & $\mathbf{0 . 0 2 7}$ \\
Insect foliage gleaner & 334 & -0.79 & 0.428 \\
Insect ground forager & 334 & -1.03 & 0.304 \\
Nectivore & 334 & -3.10 & $\mathbf{0 . 0 0 2}$ \\
Omnivorous ground forager & 334 & 2.53 & $\mathbf{0 . 0 1 1}$ \\
Seed foliage gleaner & 334 & -1.84 & 0.066 \\
Seed ground forager & 334 & 0.01 & 0.989 \\
\hline
\end{tabular}

Table 6. Wilcoxon signed rank test $(\alpha=0.05)$ comparing abundance of avifaunal groups between control and campsites in Grand Canyon National Park, Arizona, 2007-2011.

[Negative $Z$ values indicate a negative relation between abundance and campsite. Point counts were separated by site and year in the analysis $P, p$-value]

\begin{tabular}{lccl}
\hline \multicolumn{1}{c}{ Guilds } & $\begin{array}{c}\text { Number of } \\
\text { sites }\end{array}$ & $\boldsymbol{Z}$ & $\boldsymbol{P}$ \\
\hline Resident & 392 & 0.42 & 0.678 \\
Nonresident & 392 & -0.72 & 0.470 \\
Riparian nester & 392 & 0.34 & 0.731 \\
\hline Nonriparian nester & 392 & -0.10 & 0.922 \\
\hline
\end{tabular}

analysis (table 4). However, model selection uncertainty was high and only total vegetation volume emerged as a strong positive predictor of occupancy (table 3 ).

\section{Community Estimates}

We performed Wilcoxon tests on seven different avian guilds (table 5). Three dietary guilds exhibited significant differences in abundance between control sites and campsites. Both the insect aerial forager $(Z=2.21, n=334, P=0.027)$ and the omnivorous ground forager $(Z=2.53, n=334, P=0.011)$ guild had greater abundance in campsites, whereas the nectivore guild $(Z=-3.10, n=334, P=0.002)$ had greater abundance in control sites. There was no difference in abundance for resident, nonresident, riparian, or nonriparian species among camp and control sites (table 6).

Our model of observed species richness, conditioned only on total vegetation volume, was 5.7 AIC units "better" (that is, lower) than the null model, suggesting acceptable model performance. After controlling for heterogeneity in the sitelevel random effect, total vegetation volume was a statistically significant and positive predictor of observed species richness (estimate $=0.01$; unconditional standard errors, $\mathrm{SE}=0.01$; $t=2.73 ; P=0.01)$.

Avian diversity and richness did not differ between control sites and campsites, yet there were differences among visitor-use levels (table 7). Richness was significantly less in high-use sites compared to no-use sites $(t=13.55, P<0.05)$; however, there were no significant differences in diversity. When comparing low-use sites to no-use sites, there were no significant differences in richness or diversity. Mean richness $(t=20.87, P<0.05)$ and diversity $(t=12.32, P<0.05)$ were greater in NHWZs compared to OHWZs. Diversity $(F$ $(4,266)=65.96, P<0.001)$ and richness $(41.99, P<0.001)$ differed significantly among the 5 years. Tukey post-hoc comparisons of the 5 years indicated that diversity in 2007 and 2008 was significantly greater than in all other years. Diversity in 2010 was greater than $2009(q=11.34, P<0.001)$ and $2011(q=7.95, P<0.001)$. Richness in 2010 was significantly greater than all other years (table 7). Richness in 2008 was 
Table 7. Species richness estimates for each hydrological zone, use level, year, and type of site (control site versus campsite) in Grand Canyon National Park, Arizona, 2007-2011.

\begin{tabular}{|c|c|c|c|c|c|c|c|c|}
\hline Variable & $\begin{array}{c}\text { Number } \\
\text { of sites }\end{array}$ & $\begin{array}{c}\text { Number } \\
\text { of species } \\
\text { observed }\end{array}$ & $\begin{array}{l}\text { jack1 } \\
\text { mean }\end{array}$ & $\begin{array}{c}\text { jack1 } \\
\text { SE }\end{array}$ & $t$ & $\begin{array}{l}\text { Simpson } \\
\text { mean }\end{array}$ & $\begin{array}{c}\text { Simpson } \\
\text { SE }\end{array}$ & $t$ \\
\hline OHWZ & 22 & 47 & 48.51 & 4.60 & 20.87 & 7.12 & 0.83 & 12.32 \\
\hline NHWZ & 89 & 68 & 70.58 & 3.73 & & 9.42 & 0.56 & \\
\hline Control site & 86 & 56 & 60.17 & 3.51 & -1.51 & 8.83 & 0.6 & -0.30 \\
\hline Campsite & 86 & 63 & 68.08 & 3.90 & & 9.10 & 0.67 & \\
\hline High use & 47 & 50 & 51.07 & 3.33 & 13.55 & 8.78 & 0.95 & 0.26 \\
\hline Low use & 39 & 55 & 59.73 & 4.74 & 0.43 & 9.25 & 0.83 & 0.42 \\
\hline No use & 86 & 56 & 59.37 & 3.46 & & 8.82 & 0.58 & \\
\hline 2007 & 56 & 37 & 38.60 & 2.58 & $F=41.99$ & 8.66 & 0.66 & $F=65.96$ \\
\hline 2008 & 51 & 39 & 40.11 & 2.88 & & 8.39 & 1 & \\
\hline 2009 & 58 & 35 & 36.59 & 2.11 & & 6.74 & 0.47 & \\
\hline 2010 & 56 & 41 & 42.33 & 2.62 & & 7.88 & 0.71 & \\
\hline 2011 & 50 & 36 & 37.02 & 3.28 & & 7.05 & 0.89 & \\
\hline
\end{tabular}

significantly greater than $2007(q=4.09, P<0.001), 2009$ $(q=9.6, P<0.001)$, and $2011(q=8.13, P=0.03)$. Richness in 2007 was significantly greater than $2009(q=5.62, P<0.001)$ and $2011(q=4.25, P=0.02)$.

\section{Discussion}

\section{Occupancy Estimates}

For 4 of the 6 species and guilds that had reliable estimates of occupancy, geomorphic reach explained occupancy estimates the best. The nectivore guild, bluegray gnatcatcher, and black-chinned hummingbird all had higher occupancy downstream, whereas Bewick's wren had lower occupancy downstream. Spence (2006) also found that species presence varied along the Colorado River corridor. He found similar results with Bewick's wren, which was most common in the upper and middle reaches of the river, whereas black-chinned hummingbird and blue-gray gnatcatcher were found only in reaches with suitable habitat that generally occurred further downstream. The importance of geomorphic reach that we observed is probably due to the large changes in habitat, elevation, and vegetation composition as one moves down the Colorado River. Total vegetation volume (averaged across years) was the only variable that strongly influenced occupancy but for only two species. Occupancy estimates for blue-gray gnatcatcher and yellow-breasted chat increased with total vegetation volume. Similarly, Sogge and others (1998) and Spence, 2006, found that bird abundance, species richness, and diversity were positively associated with the volume of large, woody plant species.

No species or guild reflected increasing or decreasing trends over the 5-year analysis period. Relatively small numbers of detections each year, few repeat surveys, and high variability in detection or presence among years precluded our finding statistically reliable trends. Some of the variability in occupancy estimates across years, and the relatively large associated standard errors, are explained by high interannual variability in the number of detections, as well as sampling methodology issues. For the seed foraging guild, the majority of detections occurred in $2007(n=46)$ and the fewest in $2011(n=16)$. In addition, at the majority of sites that received two annual point counts, many species were detected at one point count station but not the other, creating a low estimate of detectability and therefore greater occupancy within sites sampled twice per year (Kendall and White, 2009). Additional replication visits at every site and over a longer time period would help to decrease some of the bias and variability (Guillera-Arroita and others, 2014). Spence (2006), through power analyses, also determined that more than 5 years of surveys were necessary to determine any reliable trend for individual avifaunal species in the Grand Canyon and that the number of surveys varied for each species. 
Although many of our results were similar to those of other studies, our models of occupancy (among species and guilds) typically exhibited low model weights, indicating that the variables we used were not highly informative. These results also could be partially attributed to the small number of detections obtained for each species. There were several factors involved in the collection of the avifaunal data that likely contributed to a relatively small total number of detections and a lack of precision in our estimates. The acoustic characteristics of Grand Canyon, coupled with noise from the Colorado River itself (although included as a detectability covariate), could have led to misidentification of bird calls and fewer detections overall, especially for inexperienced observers. Sites were sampled only once per year, and a majority of sites were sampled only 2 to 3 times during the entire study period, due to a range of logistical, resource, and environmental constraints. In addition, because the repeat surveys (that is, detection histories) we used in our models were derived from a single visit to a site, they were not truly independent in space or time. This unavoidable situation increased the likelihood that estimators and inferences about the factors that influence either occupancy or detection were biased. Lack of independence for detectability among sites typically results in occupancy being overstated (MacKenzie and others, 2006) and this should be considered when interpreting our results. However, our repeat surveys did have the benefit of minimizing the time over which closure was assumed for the occupancy models (Rota and others, 2011). An increased and well-distributed sample of sites, more precisely determined or measured variables, and more surveys throughout the course of a season would allow GCNP to gain a better understanding of these interactions and improve model performance at the species and guild levels.

\section{Community Estimates}

In our study, avian species richness appeared to be most influenced by vegetation volume and visitor-use levels. Specifically, observed species richness was positively associated with total vegetation volume and greater in areas with no visitor use. Species sensitive to disturbance by humans may avoid areas where human activity is common or may occur in reduced abundance decreasing the likelihood of that species being observed during a point-count survey. Decreases in richness in high visitor-use areas may have been due to lower vegetation volume at campsites or changes in vegetation structure or type (Wolf and others, 2013). Other researchers have also found a negative relation between recreation intensity and abundance of vegetation on bird species richness (Miller and others, 2003; Steven and others, 2011; Wolf and others, 2013). Schlesinger and others (2008) found that disturbance from human activity might be the most important factor for richness, surpassing even habitat loss from development. Additional information on vegetation type or other site-level information may lead to a better understanding of differences in use level. For example, a particular vegetation type or structure may be present in high- or low-use sites but not in control sites.
Consistent with our hypothesis, relative abundance of some avifaunal guilds was associated with visitor activity but not always in the way we predicted. The omnivore ground foragers had higher abundance at campsites, however, we did not see the increase in insect ground foragers that we expected. Schlesinger and others (2008) also found that omnivore abundance was positively related to recreational activity and other urban stressors. Omnivores have greater dietary flexibility, enabling their success in environments with altered food resources (Chace and Walsh, 2006). Although we did not see a difference between insect foliage gleaners and ground foragers, we did see a greater abundance for insect aerial foragers in campsites compared to control sites. Aerial insect foragers may have been more abundant in campsites because they are more open and would allow for better visibility of flying insects and easier aerial maneuvers when foraging (Eckhardt, 1979). The nectivore guild was the only guild that had significantly lower abundance at campsites compared to control sites. The nectivore guild may have had higher abundance in control sites because the black-chinned hummingbird (a dominant species in the nectivore guild in our study area) nests almost exclusively in tamarisk in the NHWZ vegetation (Brown, 1992) which was typically more abundant at control sites. Schlesinger and others (2008) also found changes in abundance for certain dietary guilds, specifically, a dramatic decrease in richness of dietary specialists, principally insectivores, granivores, and nectivores, with increased development and recreation.

The differences we detected in richness and diversity between the OHWZ and NHWZ should be interpreted cautiously. Although we used Welch's $t$-test to account for uneven sample sizes, the difference in the number of sites was so great that unbalanced sample size could have influenced our results in undesirable ways. In addition, Hellmann and Fowler (1999) found that the jack1 estimator of richness is negatively biased for small sample sizes and positively biased for large sample sizes, thereby creating a greater difference in richness among these sites than really existed. However, Spence (2006) also found that the majority of species were detected in the NHWZ. We speculate that the differences in the number of detections between the two water zones could be related to changes in vegetation community. The OHWZ vegetation community consists of a variety of xeric species, whereas the NHWZ consist mostly of riparian species. Thus, fundamental between-zone differences in vegetation and distance to water are probably influencing species diversity and abundance.

Although we were unable to discern a difference between lower amounts of vegetation volume and visitor use on avifaunal communities, both factors are probably playing a role in community structure. Decreases in avifaunal richness in highuse areas could be attributed to lesser amounts of vegetation volume and visitor-use impacts. It is likely that human activity directly affects behavior of individual bird species (Boyle and Sampson, 1985; Blumstein and others, 2005) by flushing them from nesting or foraging sites and reducing time and energy available for other important activities (Fernández-Juricic, 2000). These changes in behavior can lead to the extirpation 
of sensitive and vulnerable species, such as the reduction in richness and abundance of nectivores that we observed.

For any future efforts to sample avifauna in the Colorado River corridor, we would suggest that GCNP alter its sampling design and consider approaches to avifaunal sampling and demographic parameter estimation that are based on an occupancy framework, rather than a distance framework. An occupancy-based approach (for example, after MacKenzie and others, 2002, 2006) (1) relies on fewer assumptions than estimates of density or abundance derived in a distance framework; (2) is more often robust to low detection; (3) permits estimation of proportion of area occupied by a species, which can be a more informative statistic to managers than density or abundance; (4) allows estimation of multiseason or "dynamic" occupancy parameters, including colonization and extinction rates; and (5) provides a more flexible means of comparing community composition and diversity among groups (that is, species or guild-specific occurrence, richness, and evenness). By sampling each site twice a year and collecting data for 5 to 10 years, the park would be able to implement a multiseason occupancy approach allowing them to account for imperfect detection and determine trends in occupancy.

For the purpose of estimating demographic parameters (that is, occupancy, density) conditioned on habitat covariates, we recommend adding additional habitat or environmental variables that are measured at survey locations (directly) or using remotely sensed data (indirectly). These variables could include dominant vegetation type and patch size, slope, and elevation, among others that are hypothesized to predict occupancy for one or more target species. Indeed, Sogge and others (1998) found that patch area and volume of woody plant species in the Grand Canyon were the best predictors of bird species abundance and richness, with area alone accounting for about 65 percent of the variation in their data. In addition, if site-level inference conditioned on habitat covariates is desirable, then it is important that bird detections are made within a survey-specific area and precisely recorded.

\section{Acknowledgments}

We would like to acknowledge staff from Grand Canyon National Park who were involved in the design, implementation, and data entry for the avifauna and vegetation surveys, including R.V. Ward, Jeremy White, Janice Stroud-Settles, Rosa Palarino, Rachel Bennett, Brian Gatlin, Jane Rodgers, Cecilia Leumas, Ed Kulinski, Emily Slayton, Eric Krouse, Hattie Oswald, Jason Lovelady, Jean Lawrence, Jeremy Russell, Kevin Payne, Lydia Smith, Sarah Sells, Allison Clark, and Rebecca Kohler. We would like to further acknowledge Janice StroudSettles for her assistance and guidance in preparing data for analysis, Adia Sovie for data control, and Santiago Garcia and Jesse Anderson for data management and queries. Finally, we would like to thank Darryl MacKenzie for helpful advice on our occupancy modeling approach.

\section{References Cited}

Anderson, D.R., 2008, Model based inference in the life sciences - A primer on evidence: New York, Springer, $184 \mathrm{p}$.

Blumstein, D.T., Fernandez-Juricic, E., Zollner, P.A., and Garity, S.C., 2005, Inter-specific variation in avian responses to human disturbance: Journal of Applied Ecology, v. 42, no. 5, p. 943-953, http://dx.doi.org/10.1111/ j.1365-2664.2005.01071.x.

Boyle, S.A., and Sampson, F.B., 1985, Effects of nonconsumptive recreation on wildlife-A review: Wildlife Society Bulletin, v. 13, no. 2, p. 110-116, http://www.jstor. org/stable/3781422.

Brown, B.T., 1992, Nesting chronology, density and habitat use of black-chinned hummingbirds along the Colorado River, Arizona: Journal of Field Ornithology, v. 63, no. 4, p. 393-400, http://www.jstor.org/stable/pdfplus/4513733.pdf.

Buckland, S.T., Andersen, D.R., Burnham, K.P., Laake, J.L., Borchers, D.L., and Thomas, L., 2001, Introduction to distance sampling - Estimating abundance of biological populations: Oxford, UK, Oxford University Press, 448 p.

Burnham, K.P., and Anderson, D.R., 2002, Model selection and multimodel inference-A practical information-theoretic approach (2d ed.): New York, Springer-Verlag, 488 p.

Burnham, K.P., and Overton, W.S., 1978, Estimation of the size of a closed population when capture probabilities vary among animals: Biometrika, v. 65, no. 3, p. 625-633, http:// dx.doi.org/10.1093/biomet/65.3.625.

Burnham, K.P., and Overton, W.S., 1979, Robust estimation of population size when capture probabilities vary among animals: Ecology, v. 60, no. 5, p. 927-936, http://dx.doi. org/10.2307/1936861.

Chace, J.F., and Walsh, J.J., 2006, Urban effects on native avifauna-A review: Landscape and Urban Planning, v. 74, no. 1, p. 46-69, http://dx.doi.org/10.1016/j. landurbplan.2004.08.007.

Colwell, R.K., 2006, EstimateS-Statistical estimation of species richness and shared species from samples, version 8, accessed on March 31, 2015, at http://viceroy.eeb.uconn. edu/estimates/.

Dickson, B.G., Fleishman, E., Dobkin, D.S., and Hurteau, S.R., 2009, Relationship between avifaunal occupancy and riparian vegetation in the central Great Basin (Nevada, U.S.A.): Restoration Ecology, v. 17, no. 5, p. 722-730, http://dx.doi.org/10.1111/j.1526-100X.2009.00590.x.

Eckhardt, R.C., 1979, The adapative syndromes of two guilds of insectivorous birds in the Colorado Rocky Mountains: Ecological Monographs, v. 49, no. 2, p. 129-149, http:// dx.doi.org/10.2307/1942510. 
Fernández-Juricic, E., 2000, Local and regional effects of pedestrians on forest birds in a fragmented landscape: The Condor, v. 102, no. 2, p. 247-255, http://dx.doi. org/10.1650/0010-5422(2000)102[0247:LAREOP]2.0.CO;2.

Gotelli, N.J., and Colwell, R.K., 2011, Estimating species richness, in Magurran, A.E., and McGill, B.J., eds., Biological diversity-Frontiers in measurement and assessment: New York, Oxford University Press, p. 39-54, accessed on March 31, 2015, at https://www.uvm. edu/ ngotelli/manuscriptpdfs/Chapter\%204.pdf.

Gotelli, N.J., and Ellison, A.M., 2004, A primer of ecological statistics: Sunderland, Mass., Sinauer Associates, Inc.

Guillera-Arroita, G., 2011, Impact of sampling with replacement in occupancy studies with spatial replication: Methods in Ecology and Evolution, v. 2, no. 4, p. 401-406, http://dx.doi.org/10.1111/j.2041-210X.2011.00089.x.

Guillera-Arroita, G., Lahoz-Monfort, J.J., MacKenzie, D.I., Wintle, B., and McCarthy, M.A., 2014, Ignoring imperfect detection in biological survey is dangerous - A response to 'fitting and interpreting occupancy models': PLoS ONE, v. 9, no. 7 (e99571), http://dx.doi.org/10.1371/journal. pone.0099571.

Hellmann, J.J., and Fowler, G.W., 1999, Bias, precision, and accuracy of four measures of species richness: Ecological Applications, v. 9, no. 3, p. 824-834, http://dx.doi. org/10.1890/1051-0761(1999)009[0824:BPAAOF]2.0.CO;2.

Hines, J.E., 2006, PRESENCE2-Software to estimate patch occupancy and related parameters: U.S. Geological Survey Patuxent Wildlife Research Center Web site, accessed on March 31, 2015, at http://www.mbr-pwrc.usgs.gov/ software/presence.html.

Kendall, W.L., and White, G.C., 2009, A cautionary note on substituting spatial subunits for repeated temporal sampling in studies of site occupancy: Journal of Applied Ecology, v. 46, no. 6, p. 1182-1188, http://dx.doi.org/10.1111/j.13652664.2009.01732.x.

Knopf, F.L., Johnson, R.R., Rich, T., Samson, F.B., and Szaro, R.C., 1988, Conservation of riparian ecosystems in the United States: Wilson Bulletin, v. 100, no. 2, p. 272-284, accessed on March 31, 2015, at http://www.fs.fed.us/rm/ boise/AWAE/labs/awae_flagstaff/Hot_Topics/ripthreatbib/ knopf_etal_consripecous.pdf.

Kramer, C.Y., 1956, Extension of multiple range tests to group means with unequal numbers of replications: Biometrics, v. 12, no. 3, p. 307-310, http://www.jstor.org/stable/3001469.

Kruskal, W.H., and Wallis, W.A., 1952, Use of ranks in one-criterion variance analysis: Journal of the American Statistical Association, v. 47, no. 260, p. 583-621, http:// www.jstor.org/stable/2280779.
Lande, R., DeVries, P.J., and Walla, T.R., 2000, When species accumulation curves intersect-Implications for ranking diversity using small samples: Oikos, v. 89, no. 3, p. 301605, http://dx.doi.org/10.1034/j.1600-0706.2000.890320.x.

MacKenzie, D.I., Nichols, J.D., Hines, J.E., Knutson, M.G., and Franklin, A.B., 2003, Estimating site occupancy, colonization, and local extinction when a species is detected imperfectly: Ecology, v. 84, no. 8, p. 2200-2207, http:// dx.doi.org/10.1890/02-3090.

MacKenzie, D.I., Nichols, J.D., Lachman, G.B., Droege, S., Royle, J.A., and Langtimm, C.A., 2002, Estimating site occupancy rates when detection probabilities are less than one: Ecology, v. 83, no. 8, p. 2248-2255, http://dx.doi. org/10.1890/0012-9658(2002)083[2248:ESORWD]2.0.CO;2.

MacKenzie, D.I., Nichols, J.D., Royle, J.A., Pollack, K.H., Bailey, L.L., and Hines, J.E., 2006, Occupancy estimation and modeling - Inferring patterns and dynamics of species occurrence: San Diego, Calif., Academic Press, 324 p.

MacKenzie, D.I., Royle, J.A., Brown, J.A., and Nichols, J.D., 2004, Occupancy estimation and modeling for rare and elusive populations, in Thompson, W.L., ed., Sampling rare or elusive species: Washington, D.C., Island Press, p. 149-172.

Magurran, A.E., 2004, Measuring biological diversity: Malden, Mass., Blackwell Publishing.

Miller, J.R., and Hobbs, N.T., 2000, Recreational trails, human activity, and nest predation in lowland riparian areas: Landscape and Urban Planning, v. 50, p. 227-236, accessed on March 31, 2015, at http://millerlab.nres.illinois.edu/ pdfs/Recreational\%20Trails, \%20Human \%20Activity, $\% 20$ and $\% 20$ Nest $\% 20$ Predation $\% 20$ in $\% 20$ Lowland $\% 20$ Riparian\%20Areas.pdf.

Miller, J.R., Wiens, J.A., Hobbs, N.T., and Theobald, D.M., 2003, Effects of human settlement on bird communities in lowland riparian areas of Colorado (USA): Ecological Applications, v. 13, no. 4, p. 1041-1059, http://dx.doi. org/10.1890/1051-0761(2003)13[1041:EOHSOB]2.0.CO;2.

Mills, G.S., Dunning, J.B., and Bates, J.M., 1991, The relationship between breeding bird density and vegetation volume: Wilson Bulletin, v. 103, no. 3, p. 468-479, http:// www.jstor.org/stable/4163050.

National Park Service, 2006, Colorado River Management Plan: U.S. Department of the Interior, National Park Service, Grand Canyon National Park, 35 p., accessed on March 31, 2015, at http:/www.nps.gov/grca/learn/ management/upload/CRMPIF_s.pdf.

Palmer, M.W., 1990, The estimation of species richness by extrapolation: Ecology, v. 714, no. 3, p. 1195-1198, http:// www.jstor.org/stable/1937387. 
Rosenberg, K.V., Ohmart, R.D., and Anderson, B.W., 1982, Community organization of riparian breeding birdsResponse to an annual resource peak: The Auk, v. 99, no. 2, p. 260-274, accessed on March 31, 2015, at https://sora.unm. edu/sites/default/files/journals/auk/v099n02/p0260-p0274.pdf.

Rosenstock, S.S., Anderson, D.R., Giesen, K.M., Leukering, T., and Carter, M.F., 2002, Landbird counting techniques - Current practices and an alternative: The Auk, v. 119, no. 1, p. 46-53, http://dx.doi.org/10.1642/00048038(2002)119[0046:LCTCPA]2.0.CO;2.

Rota, C.T., Fletcher, R.J., Jr., Evans, J.M., and Hutto, R.L., 2011, Does accounting for imperfect detection improve species distribution models?: Ecography, v. 34, no. 4, p. 659-670, http:// dx.doi.org/10.1111/j.1600-0587.2010.06433.x.

Ruxton, G.D., 2006, The unequal variance $t$-test is an underused alternative to Student's $t$-test and the Mann-Whiteny $U$ test: Behavioral Ecology, v. 17, no. 4, p. 688-690, http:// dx.doi.org/10.1093/beheco/ark016.

Schlesinger, M.D., Manley, P.N., and Holyoak, M., 2008, Distinguishing stressors acting on land bird communities in an urbanizing environment: Ecology, v. 89, no. 8, p. 23022314, http://dx.doi.org/10.1890/07-0256.1.

Schmidt, J.C., and Graf, J.B., 1990, Aggradation and degradation of alluvial sand deposits, 1965-1986, Colorado River, Grand Canyon National Park, Arizona: U.S. Geological Survey Professional Paper 1493, 74 p., http://pubs.er.usgs. gov/usgspubs/citfor/pp/pp1493.

Schoener, T.W., 1968, Sizes of feeding territories among birds: Ecology, v. 49, no. 1, p. 123-1471, http://www.jstor.org/ stable/1933567.

Skagen, S.K., Melcher, C.P., Howe, W.H., and Knopf, F.L., 1998, Comparitive use of riparian corridors and oases by migrating birds in southeast Arizona: Conservation Biology, v. 12, no. 4, p. 896-909, http://dx.doi.org/10.1111/j.15231739.1998.96384.x.

Sogge, M.K., Felley, D., and Wotawa, M., 1998, Riparian bird community ecology in the Grand Canyon-final report to the Bureau of Reclamation: Flagstaff, Ariz., U.S. Geological Survey, Colorado Plateau Field Station report, cooperative agreement no. 8031-8-0002, 276 p. and appendixes., accessed on March 31, 2015, at http://www.gcmrc.gov/ library/reports/biological/terrestrial/Sogge2000b.pdf.
Spence, J.R., 2006, The riparian and aquatic bird communities along the Colorado River from Glen Canyon Dam to Lake Mead, 1996-2000 - final report: Flagstaff, Ariz., National Park Service, Resource Management Division, Glen Canyon National Recreation Area, submitted to U.S. Geological Survey, Grand Canyon Monitoring and Research Center, 283 p., accessed on March 31, 2015, at http://www.gcmrc.gov/ library/reports/biological/terrestrial/Spence2006.pdf.

Steven, R., Pickering, C., and Castley, J.G., 2011, A review of the impacts of nature based recreation on birds: Journal of Environmental Management, v. 92, no. 10, p. 2287-2294, http://dx.doi.org/10.1016/j.jenvman.2011.05.005.

Szaro, R.C., and Jakle, M.D., 1985, Avian use of a desert riparian island and its adjacent scrub habitat: The Condor, v. 87, no. 4, p. 511-519, http://www.jstor.org/stable/1367948.

Thomas, L., Buckland, S.T., Rexstad, E.A., Laake, J.L., Strindberg, S., Hedley, S.L., Bishop, J.R.B., Marques, T.A., and Burnham, K.P., 2010, Distance software-Design and analysis of distance sampling surveys for estimating population size: Journal of Applied Ecology, v. 47, no. 1, p. 5-14, http://dx.doi.org/10.1111/j.1365-2664.2009.01737.x.

Tukey, J.W., 1953, The problem of multiple comparisons: Princeton, N.J., Princeton University, unpublished report.

Wilcoxon, F., 1945, Individual comparisons by ranking methods: Biometrics Bulletin, v. 1, no. 6, p. 80-83, http:// www.jstor.org/stable/3001968.

Williams, R.L., 2000, A note on robust variance estimation for cluster-correlated data: Biometrics, v. 56, no. 2, p. 645-646, http://dx.doi.org/10.1111/j.0006-341X.2000.00645.x.

Wolf, I., Hagenloh, G., and Croft, D.B., 2013, Vegetation moderates impacts of tourism usage on bird communities along roads and hiking trails: Journal of Environmental Management, v. 129, p. 224-234, http://dx.doi. org/10.1016/j.jenvman.2013.07.017.

Zachmann, L.J., Horncastle, V., and Dickson, B.G., 2012, Colorado River management plan-Research, monitoring, and mitigation program data analysis: Flagstaff, Northern Arizona University, The Lab of Landscape Ecology and Conservation Biology, School of Earth Sciences and Environmental Sustainability, 68 p. 
Appendix 
Appendix A. Results of bird species point counts from 2007-2011 along the Colorado River in Grand Canyon National Park.

[Data from the 48 of these sites that received two point counts in a given year. Seventy-two species from 10 different dietary guilds were detected. pt1, point count 1; pt2, point count 2; NA, not applicable]

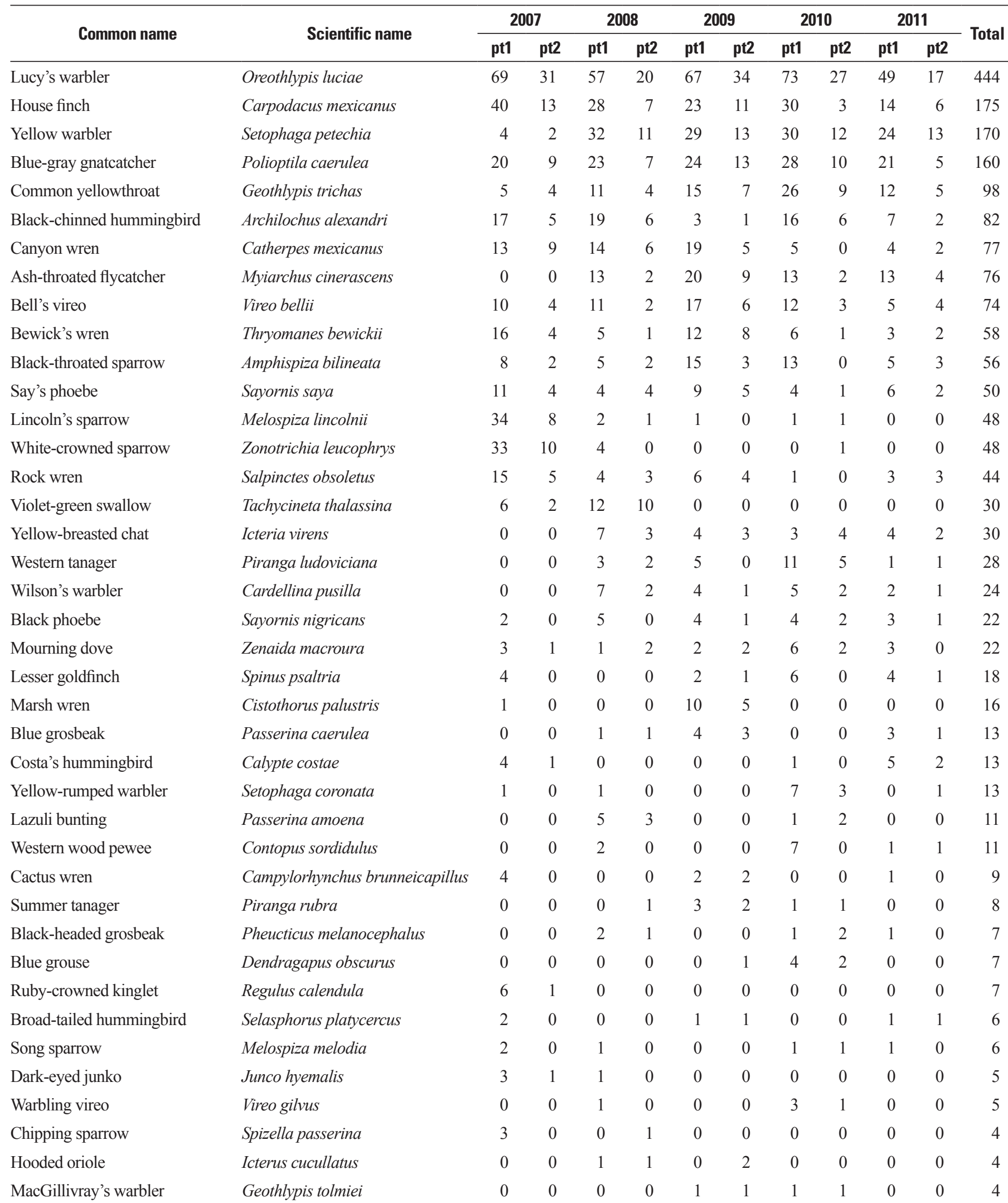


Appendix A.-Continued

\begin{tabular}{|c|c|c|c|c|c|c|c|c|c|c|c|c|}
\hline \multirow{2}{*}{ Common name } & \multirow{2}{*}{ Scientific name } & \multicolumn{2}{|c|}{2007} & \multicolumn{2}{|c|}{2008} & \multicolumn{2}{|c|}{2009} & \multicolumn{2}{|c|}{2010} & \multicolumn{2}{|c|}{2011} & \multirow{2}{*}{ Tota } \\
\hline & & pt1 & $\mathrm{pt2}$ & pt1 & pt2 & pt1 & pt2 & pt1 & pt2 & pt1 & pt2 & \\
\hline Northern mockingbird & Mimus polyglottos & 2 & 1 & 0 & 0 & 0 & 0 & 1 & 0 & 0 & 0 & 4 \\
\hline Brown-crested flycatcher & Myiarchus tyrannulus & 0 & 0 & 0 & 0 & 2 & 0 & 0 & 0 & 1 & 0 & 3 \\
\hline Indigo bunting & Passerina cyanea & 0 & 0 & 1 & 0 & 0 & 0 & 2 & 0 & 0 & 0 & 3 \\
\hline Olive-sided flycatcher & Contoopus cooperi & 0 & 0 & 0 & 0 & 2 & 1 & 0 & 0 & 0 & 0 & 3 \\
\hline Rose-breasted grosbeak & Pheucticus ludovicianus & 0 & 0 & 0 & 0 & 0 & 0 & 2 & 1 & 0 & 0 & 3 \\
\hline Sage sparrow & Artemisiospiza nevadensis & 0 & 0 & 1 & 0 & 1 & 1 & 0 & 0 & 0 & 0 & 3 \\
\hline Black-chinned sparrow & Spizella atrogularis & 0 & 0 & 2 & 0 & 0 & 0 & 0 & 0 & 0 & 0 & 2 \\
\hline Brewer’s sparrow & Spizella breweri & 2 & 0 & 0 & 0 & 0 & 0 & 0 & 0 & 0 & 0 & 2 \\
\hline Bullock's oriole & Icterus bullockii & 0 & 0 & 0 & 0 & 0 & 0 & 0 & 1 & 1 & 0 & 2 \\
\hline Great tailed grackle & Quiscalus mexicanus & 0 & 0 & 0 & 0 & 1 & 0 & 0 & 0 & 1 & 0 & 2 \\
\hline House sparrow & Passer domesticus & 1 & 0 & 1 & 0 & 0 & 0 & 0 & 0 & 0 & 0 & 2 \\
\hline Loggerhead shrike & Lanius ludovicianus & 0 & 0 & 0 & 0 & 1 & 0 & 1 & 0 & 0 & 0 & 2 \\
\hline Magnolia warbler & Setophaga magnolia & 0 & 0 & 0 & 0 & 0 & 2 & 0 & 0 & 0 & 0 & 2 \\
\hline Rufous-crowned sparrow & Aimophila ruficeps & 0 & 0 & 0 & 0 & 1 & 1 & 0 & 0 & 0 & 0 & 2 \\
\hline Scott's oriole & Icterus parisorum & 0 & 0 & 0 & 0 & 0 & 0 & 2 & 0 & 0 & 0 & 2 \\
\hline Spotted sandpiper & Actitis macularius & 0 & 0 & 0 & 0 & 0 & 0 & 0 & 0 & 1 & 1 & 2 \\
\hline Southwestern willow flycatcher & Empidonax traillii extimus & 0 & 0 & 0 & 0 & 0 & 0 & 1 & 0 & 1 & 0 & 2 \\
\hline Brewer’s blackbird & Euphagus cyanocephalus & 0 & 0 & 0 & 0 & 0 & 0 & 0 & 1 & 0 & 0 & 1 \\
\hline Coopers hawk & Accipiter cooperii & 1 & 0 & 0 & 0 & 0 & 0 & 0 & 0 & 0 & 0 & 1 \\
\hline Greater roadrunner & Geococcyx californianus & 1 & 0 & 0 & 0 & 0 & 0 & 0 & 0 & 0 & 0 & 1 \\
\hline Green-tailed towhee & Pipilo chlorurus & 1 & 0 & 0 & 0 & 0 & 0 & 0 & 0 & 0 & 0 & 1 \\
\hline Hammond's flycatcher & Empidonax hammondii & 0 & 0 & 0 & 0 & 0 & 0 & 0 & 0 & 1 & 0 & 1 \\
\hline Hermit warbler & Setophaga occidentalis & 1 & 0 & 0 & 0 & 0 & 0 & 0 & 0 & 0 & 0 & 1 \\
\hline Peregrine falcon & Falco peregrinus & 0 & 0 & 1 & 0 & 0 & 0 & 0 & 0 & 0 & 0 & 1 \\
\hline Red-winged blackbird & Agelaius phoeniceus & 0 & 0 & 0 & 0 & 0 & 0 & 0 & 0 & 0 & 1 & 1 \\
\hline Tree swallow & Tachycineta bicolor & 1 & 0 & 0 & 0 & 0 & 0 & 0 & 0 & 0 & 0 & 1 \\
\hline Turkey vulture & Cathartes aura & 0 & 0 & 0 & 0 & 0 & 0 & 0 & 1 & 0 & 0 & 1 \\
\hline White-throated sparrow & Zonotrichia albicollis & 1 & 0 & 0 & 0 & 0 & 0 & 0 & 0 & 0 & 0 & 1 \\
\hline \multicolumn{13}{|c|}{ Dietary guild } \\
\hline Insect foliage gleaner & NA & 80 & 32 & 74 & 23 & 77 & 36 & 85 & 32 & 66 & 23 & 528 \\
\hline Insect ground forager & NA & 70 & 22 & 29 & 10 & 46 & 16 & 22 & 6 & 14 & 5 & 240 \\
\hline Seed ground forager & NA & 47 & 13 & 30 & 8 & 24 & 12 & 34 & 5 & 16 & 6 & 195 \\
\hline Insect aerial forager & NA & 17 & 6 & 33 & 14 & 30 & 12 & 25 & 5 & 25 & 6 & 173 \\
\hline Nectivore & NA & 24 & 7 & 19 & 6 & 5 & 4 & 23 & 7 & 16 & 5 & 116 \\
\hline Omnivorous ground forager & NA & 4 & 4 & 0 & 1 & 1 & 0 & 5 & 2 & 1 & 2 & 20 \\
\hline Seed foliage gleaner & NA & 4 & 0 & 0 & 0 & 2 & 1 & 6 & 0 & 4 & 1 & 18 \\
\hline Fruit foliage gleaner & NA & 0 & 0 & 0 & 0 & 4 & 1 & 0 & 0 & 1 & 2 & 8 \\
\hline Carnivore soarer & NA & 1 & 0 & 1 & 0 & 0 & 0 & 0 & 1 & 0 & 0 & 3 \\
\hline Small animal prober & NA & 0 & 0 & 0 & 0 & 0 & 0 & 0 & 0 & 1 & 1 & 2 \\
\hline
\end{tabular}




\title{
Bat Surveys in Pipe Spring National Monument and Ensuing Interpretive Programs
}

\author{
By Cameron Jack, ${ }^{1 *}$ John R. Taylor, ${ }^{1}$ Andrea Bornemeier, ${ }^{2}$ and Amber Van Alfen ${ }^{2}$
}

\begin{abstract}
Located in northern Arizona, springs emerge within Pipe Spring National Monument and provide one of the few stable water sources in the desert between the Grand Canyon and Zion National Park. Wildlife, Paiute Indians, Mormon pioneers, and modern-day visitors have all used this oasis as a life-sustaining rest area. Winsor Castle, a fort built over the main spring, and two adjacent developed ponds all needed maintenance, which necessitated that bat surveys be conducted so as to minimize the effect of construction on the wildlife that depends on the ponds. Here we discuss how the results of acoustic surveys and mist-netting events led to an understanding of the importance of the springs to bat populations and how this research has sparked a successful string of interpretive programs for the monument.
\end{abstract}

\section{Introduction}

Pipe Spring National Monument and the Kaibab Paiute Indian Reservation are located on the Arizona Strip, the area of Arizona north of the Grand Canyon and spanning the UtahArizona border. During the late 19th and early 20th centuries, Pipe Spring was the main water source for Mormon settlers traveling a primitive wagon road known as the Honeymoon Trail. Today the monument is 40 acres ( 16.19 hectares) and is surrounded by the reservation. The water from the natural springs continues to be stored in two ponds near the monument's historical structures. These ponds are a contributing resource to the historical district and cultural landscape. There are two springs at the monument emerging from beneath the fort. The springs are fed by the Navajo Sandstone aquifer to the northwest, by way of the Sevier Fault (McKoy, 2000).

The ponds continue to provide a constant supply of water for livestock and irrigation for the gardens and fruit trees that reflect the park's rich history. These open water sources are also beneficial to local wildlife. A mammal survey conducted

\footnotetext{
'Southern Utah University

${ }^{2}$ National Park Service

"Now at University of Florida
}

by the U.S. Geological Survey in 2001 documented that at least 21 species use the area. Squirrels, rats, shrews, and mice are food sources for coyotes, bobcats, badgers, and foxes (S. Haymond, written commun., 2003). Red-tailed hawks and great horned owls also spend time in the trees surrounding the ponds in hopes of gaining an easy meal, and bats rely on the ponds as a place to hunt insects and drink.

Over time the stone masonry of the nearby ponds, constructed by Mormon ranchers in the 1870s, has deteriorated and is in need of repair. Leaks in the clay-bottom pond basins have led to water loss in the surrounding soil, leaving less water for garden and orchard maintenance. To make the necessary repairs, the ponds would need to be drained. Though repairs would be easiest to make in the summer, draining the ponds during that time could be devastating to the wildlife that depend on the water for survival. Park staff decided to review options for timing of the construction to minimize the effects it would have on wildlife.

Of all the animals that depend on the ponds, bats are the only ones that need an open water source with a calm surface. While a small squirrel or fox may be able to obtain water from a puddle or stream, bats require a water source that will allow them to drink on the wing. Furthermore, the bat diversity at Pipe Spring National Monument is represented by some of the largest and smallest bats in Utah and Arizona. Much like airplanes, big bats require a larger flyway when drinking, while the smaller, more agile bats can often drink from small cattle troughs. Park officials decided that if the ponds required draining for maintenance, the repairs should be made when bats' use of the ponds is at its lowest level for the year.

\section{Methods}

Bat surveys at the monument have been going on for more than 30 years, but nearly all of this work has taken place from June through August, the peak time for bat activity (J. Tyburec, written commun., 2001; H.S. Kim and S. Johnson, written commun., 2004; S. Johnson, written commun., 2005). Currently, 9 of the 14 species that have been captured at Pipe Spring National Monument are considered Species of Special Concern by the U.S. Fish and Wildlife Service (Hinman and Snow, 2003). It has been suggested by previous studies that at 
least 17 species may be present in the area, but the additional 3 species not yet captured have only been included by association with the habitat.

Our surveys began in March 2011 and ended in October 2012. Over this time we made acoustic recordings of bat activity at the ponds for one night every two weeks. This technique involves coupling a full-spectrum ultrasonic bat detector (Pettersson D240X, Pettersson Elektronick) to an H2 (Zoom) digital voice recorder. We placed the detector $3 \mathrm{~m}(9 \mathrm{ft})$ above ground by strapping it to a large cottonwood tree and facing it toward the ponds. It was protected from the elements by a PVC housing constructed from a large electrical junction box. The audio signal was routed through a 4-meter-long $(12 \mathrm{ft})$ audio cable to the recorder, which was housed in a weather-resistant toolbox at the base of the tree. This setup allowed both the recorder and the detector to run off of a stable power source and facilitated data downloading and periodic changing of digital storage media (16 GB flash memory) used by the recorder.

The bat detection system was turned on at sunset and run continuously through the night to provide approximately 12 hours of monitoring. Analysis of the data was achieved using SonoBat version 3.03 software. Before analysis, all files were parsed and scrubbed using SonoBat. This relatively quick process separated short snippets of audio calls that did not contain obvious bat calls. This process significantly reduced processing time. After scrubbing, all remaining recordings were subjected to automated analysis using the species classification feature of the software. For a call to receive a bat species classification consensus, it had to have a discreet probability of likelihood of at least 0.90 and a minimum acceptable call quality of 0.80 . These user-controlled settings are the software's default settings and were used for all call analyses.

Using SonoBat U.S. West Summarizer, reports were generated to summarize individual monitoring nights. These reports include consensus counts, corrected counts, and the estimated likelihood of presence (ELP) for each individual species. The consensus count is a species-specific tally of consensus decisions generated by the software. The corrected count considers a species respective call ambiguity and reduces the consensus count to minimize misclassifications and provides a more confident and conservative count. The ELP is a probabilistic estimate based on the known ambiguity and overlap of each particular species (SonoBat version 3.2). A species with a very distinctive call will therefore require fewer recordings to generate a high ELP. Due to temporal variation of species compositions, and to limit false positives, summary reports were generated from single night, single site data (Hayes, 1997).

We note that acoustic identification such as this is probabilistic, and not as reliable as identifying bats through morphological or genetic methods. For this reason, we also conducted mist-netting events each month, as close to the new moon as possible. A typical survey consisted of deploying three nets, 6-9 m (19-30 ft) in length, in the following array: one net on the sidewalk passing between the two ponds and two nets around the pond perimeter (fig. 1). Nets were opened at sundown and closed three hours later. During this time, handlers carefully

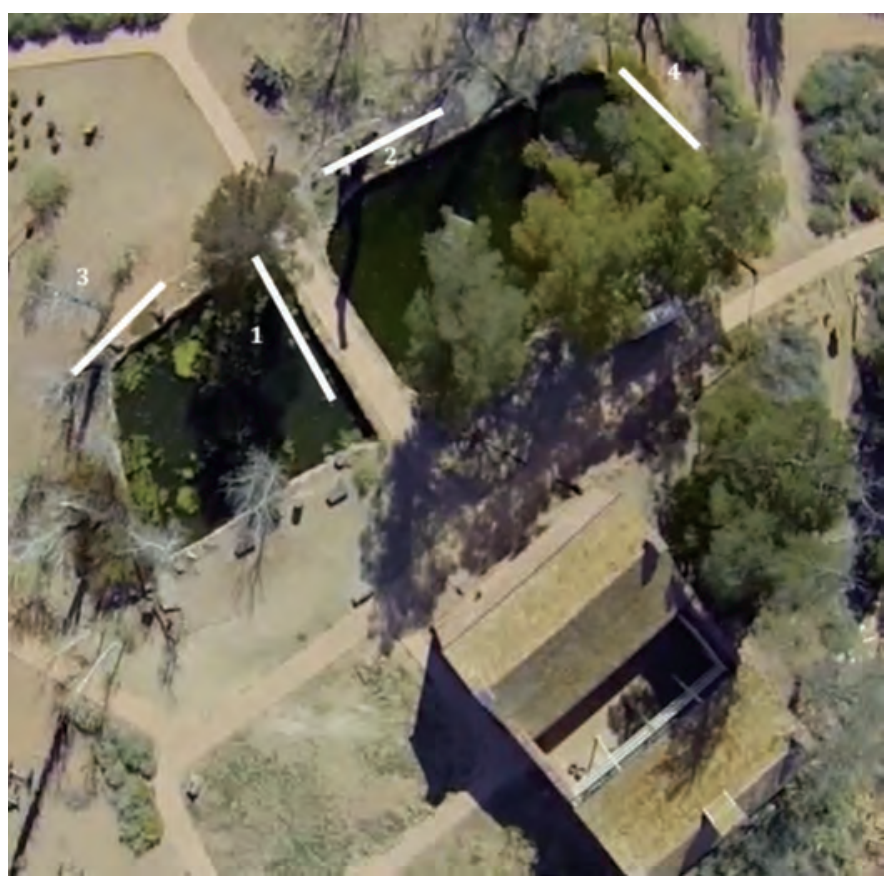

Figure 1. An aerial photograph of Winsor Castle and the adjacent ponds. The white lines depict the typical netting arrangement during bat surveys. Sites 1 and 2 were always in place, with sites 3 and 4 as optional.

removed bats caught in the nets, took measurements, weighed and identified their species, examined them for parasites, and released them. Bats were also inspected for signs of white-nose syndrome, a fungal infection that is sweeping across the nation and reducing bat populations. The bat handlers took precautions to guard against spreading disease between bats by using disposable gloves for each capture. Furthermore, all researchers were vaccinated for rabies and were trained in bat handling.

\section{Results}

Most of the calls detected by the Pettersson D240x were from bat species that had already been identified in previous studies. The most common bats netted in the area were the western pipistrelle (Parastrellus hesperus), which comprised 25.2 percent of all captures, the fringed myotis (Myotis thysanodes), 20.3 percent, and the California myotis (Myotis californicus), 12.9 percent. In comparison, a few bats were only detected acoustically, specifically the long-legged myotis (Myotis volans), the western red bat (Lasiurus blossevillii), long-eared myotis (Myotis evotis), and the western mastiff bat (Eumops perotis) (table 1).

June through September exhibited the greatest species richness. Two time periods, late May/early June and late September/early October, both resulted in more than 15 of the 17 possible species being detected acoustically. Though these two time periods were well represented by different species, 
Table 1. Listing of the number of species netted and acoustically detected over the course of the study in comparison to past studies.

[Acoustic numbers represent the conservative corrected count as determined by the SonoBat software. The letter " $\mathrm{X}$ " indicates presence and the letter " $\mathrm{P}$ " indicates that the species is possibly present as determined by the respective authors]

\begin{tabular}{|c|c|c|c|c|c|}
\hline \multirow[b]{2}{*}{ Species } & \multicolumn{2}{|c|}{ This study } & \multicolumn{3}{|c|}{ Communication } \\
\hline & Netted & Acoustic & $\begin{array}{l}\text { Bogan } \\
(2005) \\
\end{array}$ & $\begin{array}{c}\text { Johnson } \\
\text { (2005) }\end{array}$ & $\begin{array}{c}\text { Tyburec } \\
\text { (2013) }\end{array}$ \\
\hline Antrozous pallidus & 20 & 7 & $\mathrm{X}$ & $\mathrm{X}$ & \\
\hline Corynorhinus townsendii & 1 & 16 & $\mathrm{X}$ & $\mathrm{X}$ & $\mathrm{X}$ \\
\hline Eptesicus fuscus & 14 & 1 & $\mathrm{X}$ & $\mathrm{X}$ & \\
\hline Euderma maculatum & 0 & 3 & $\mathrm{P}$ & & $\mathrm{X}$ \\
\hline Eumops perotis & 0 & 3 & & & $\mathrm{X}$ \\
\hline Idionycteris phyllotis ${ }^{*}$ & 7 & $0^{*}$ & $\mathrm{X}$ & $\mathrm{X}$ & $\mathrm{X}$ \\
\hline Lasionycteris noctivagans & 0 & 3 & $\mathrm{X}$ & $\mathrm{X}$ & \\
\hline Lasiurus blossevillii & 0 & 1 & $\mathrm{P}$ & & \\
\hline Lasiurus cinereus & 3 & 7 & $\mathrm{X}$ & $\mathrm{X}$ & $\mathrm{X}$ \\
\hline Myotis californicus & 23 & 178 & $\mathrm{X}$ & $X$ & $\mathrm{X}$ \\
\hline Myotis ciliolabrum & 4 & 28 & $\mathrm{X}$ & $\mathrm{X}$ & $\mathrm{X}$ \\
\hline Myotis evotis & 0 & 1 & & $\mathrm{X}$ & \\
\hline Myotis lucifugus & 2 & 1 & $\mathrm{X}$ & $\mathrm{X}$ & $\mathrm{X}$ \\
\hline Myotis thysanodes & 40 & 64 & $\mathrm{X}$ & $\mathrm{X}$ & $\mathrm{X}$ \\
\hline Myotis volans & 13 & 1 & $\mathrm{X}$ & $\mathrm{X}$ & \\
\hline Myotis yumanensis & 9 & 8 & $\mathrm{X}$ & $\mathrm{X}$ & $\mathrm{X}$ \\
\hline Parastrellus hesperus & 50 & 740 & $\mathrm{X}$ & $\mathrm{X}$ & $\mathrm{X}$ \\
\hline Tadarida brasiliensis & 9 & 569 & $\mathrm{X}$ & $\mathrm{X}$ & $\mathrm{X}$ \\
\hline
\end{tabular}

*Idioycleris phyllotis does not currently have a reference call library in SonoBat. These calls were most likely detected but not classified by the software.

most of the summer month time periods routinely resulted in more than 10 species being detected (fig. 2).

The spotted bat (Euderma maculatum), E. perotis, $L$. blossevillii, and M. evotis are bats that have been detected acoustically but have never been caught at Pipe Spring National Monument. The silver-haired bat (Lasionycteris noctivagans) was also detected acoustically, but has not been caught at the monument since 2004. There were no bat species caught during the two-year study that had not been caught in prior studies (table 1).

Taking into account this study and all previously known studies conducted at Pipe Spring National Monument, we suggest that there may be as many as 18 species of bats in residence in the area. However, of these 18, E. maculatum, E. perotis, L. blossevillii, and M. evotis have only been documented acoustically. At the time of publication, an extensive study has been initiated to build a statistically strong bat-call reference library for E. perotis, as this species may be more prevalent in the area than previously thought.

Netting generated a fair amount of excitement among park staff and visitors. It quickly became apparent these

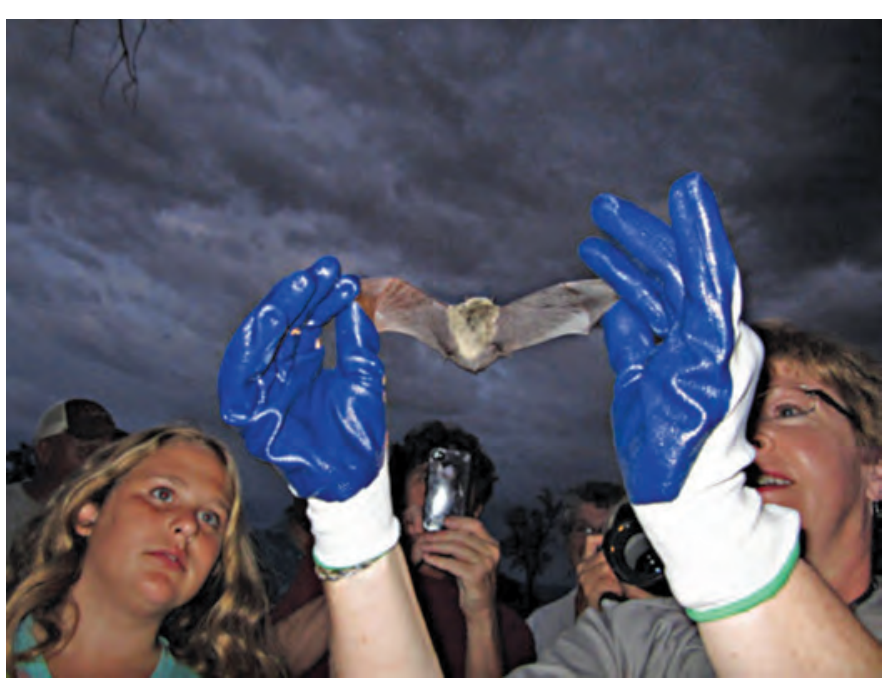

Figure 2. Andrea Bornemeier, Chief of Interpretation at Pipe Spring National Monument, shows a bat to eager participants during one of the educational outreach programs. 
periodic events could serve as a foundation for new interpretive programs to increase public awareness of and appreciation for bats. The park's interpretive team quickly went about creating posters and sending out e-mails advertising these public events.

In the survey's first year, a group of college students who were visiting as part of the Partners in Parks program attended one of the mist-netting events. A number of Boy Scouts participated in the evening activities to fulfill requirements for the mammal study merit badge, and introductory biology students from Southern Utah University (SUU) benefited from engaging in the scientific research, despite varying career interests. Other participants also served as interns under the SUU-National Park Service Intergovernmental Internship Cooperative. We soon expanded these public netting events to include other topics, such as "Bats and the Night Sky," which paired an evening of astronomy with bat natural history. "Bats and Bugs" soon followed, allowing the public to view insects caught at the same time as bats. Finally, "Bats and Salamanders" allowed participants to net salamanders from the ponds and learn about their life histories.

In all, approximately 600 participants enjoyed an evening under the stars learning about bats and a variety of other topics. We drew participants from nearly 100 miles (161 kilometers) away, not to mention travelers who just happened to be at the monument and decided to wait for the evening programs. These engaging experiences help visitors connect to the monument in a very personal way (fig. 2).

\section{Discussion}

Several bat species deemed sensitive by the U.S. Fish and Wildlife Service were either netted or acoustically detected at Pipe Spring: the Yuma myotis (Myotis yumanensis), M. evotis, $M$. thysanodes, $M$. volans, the western small-footed myotis (Myotis ciliolabrum), the spotted bat (E. maculatum), the Allen's big-eared bat (Idionycteris phyllotis), the Townsend's big-eared bat (Corynorhinus townsendii), and the western mastiff bat (E. perotis) (Hinman and Snow, 2003).

E. perotis and E. maculatum were the only two sensitive species not caught on site during the two-year study, though we are certain both were recorded acoustically many times in 2011. In addition, C. townsendii, M. evotis, E. perotis, and E. maculatum were recorded in 2011, but not 2012. Perhaps only a small population of these sensitive species live at Pipe Spring, although this hypothesis could be affected by the smaller sample size in 2012.

One of the strengths of acoustic monitoring is the tremendous amount of data gathered over many sampling hours through very little effort. It provides a relatively easy way to monitor the park's bats throughout the year, potentially spotting interesting patterns that may not be elucidated by mist-netting alone. One such pattern can be found in table 2: half of the species detected in this study were both captured and acoustically detected and appear to be present in area for much of the year. Of these, P. hesperus and T. brasiliensis seem perennial to the area (table 2; see also table 1). The other nine species proved difficult to capture or acoustically detect each field season, suggesting that they may be in the area only sporadically, possibly using the area as a migratory stop or wintering location. It is also highly likely that species like E. maculatum, E. perotis, T. brasiliensis, and Lasiurus sp. could be either migratory and (or) flying over the area during feeding bouts.

We found that bats' use of the ponds in Pipe Spring National Monument is steady from May through October. Bat activity and diversity drop off sharply by mid-November and stay low until spring (fig. 3). Pipe Spring National Monument appears to be an important water and food source for bats and should be treated with care. Maintenance that requires pond drainage should occur in November, when daytime temperatures average $13{ }^{\circ} \mathrm{C}\left(56^{\circ} \mathrm{F}\right)$ and nighttime lows are around freezing, and should be avoided from May through late October, especially during birthing periods for particular wildlife species. In the summer of 2012, the rock walls surrounding the ponds were excavated, reinforced, and reconstructed, but that work did not require the ponds to be drained.

The National Academy of Sciences states in their Framework for K-12 Science Education that an understanding of science and engineering is essential for every American citizen (Quinn and others, 2012). Furthermore, they suggest that these scientific principles and practices should be made on a personal level in a meaningful and relevant way. This study initially focused solely on collecting bat data, but quickly adapted to provide the meaningful and relevant scientific perspective, delivered at the personal level: what began as a straightforward research project blossomed into the synergistic development of engaging interpretive programs.

One college student who attended the bats and salamanders program wrote a paper explaining the "profound effect" the experience had had on him. It helped him decide that a career in science may be exactly what he has been searching for. Another student wrote to say she had never seen a bat before and loved learning about them and listening to their calls. By the end of the night she had found herself referring to them as "cute little guys" and realized that, as she said, "this is exactly why I've come to college ... to explore new things." The possibilities of expanding interpretive programs in conjunction with park research are being realized in Pipe Spring National Monument and are a bright and refreshing way to engage the childlike curiosity in all park visitors.

The excitement generated by this program has spread to other nearby parks, which also view this format as offering great possibilities. The 2013 field season brought bat inventory work and similar interpretive programs at nearby Zion and Bryce Canyon National Parks and Cedar Breaks National Monument. Unlike Pipe Spring, those parks experience much higher visitation, which necessitates limiting the number of participants. Nevertheless, the goal is the same: to help visitors connect physically and emotionally with the public lands they love. We hope these connections will last a lifetime, influencing participants to continue to protect and care for their national parks. 
Table 2. Estimated likelihood of presence as determined by SonoBat.

[Summary of all acoustic data (2011 and 2012 combined). Each month was divided in half to provide greater resolution. Estimated likelihood of presence data is given in percent likelihood (\%), but the netted numbers are individuals of each species caught. M. californicus and M. ciliolabrum hand identifications may be inaccurate; we used the latest keys available to us through the Western Bat Working Group, but DNA was not used for identification purposes]

\begin{tabular}{|c|c|c|c|c|c|c|c|c|c|c|c|c|c|c|c|}
\hline \multirow{2}{*}{ Species } & \multicolumn{3}{|c|}{ March } & \multicolumn{3}{|c|}{ April } & \multicolumn{3}{|c|}{ May } & \multicolumn{3}{|c|}{ June } & \multicolumn{3}{|c|}{ July } \\
\hline & $1-15$ & $16-31$ & Netting & $1-15$ & $16-30$ & Netting & $1-15$ & $16-31$ & Netting & $1-15$ & $16-31$ & Netting & $1-15$ & $16-31$ & Netting \\
\hline Antrozous pallidus & & & & & & 1 & $24 \%$ & & 4 & $100 \%$ & $23 \%$ & 6 & $24 \%$ & $62 \%$ & 6 \\
\hline Corynorhinus townsendii & & & & & & & $25 \%$ & & & $25 \%$ & $99 \%$ & 1 & & & \\
\hline Eptesicus fuscus & & & & & $23 \%$ & & & & 5 & $9 \%$ & & 7 & $23 \%$ & $23 \%$ & \\
\hline Euderma maculatum & & & & & & & & & & & & & $86 \%$ & $86 \%$ & \\
\hline Eumops perotis & & & & & & & & $99 \%$ & & $99 \%$ & & & & & \\
\hline Idionycteris phyllotis & & & & & & & & & 1 & & & 1 & & & 4 \\
\hline Lasionycteris noctivagans & & $23 \%$ & & & & & & & & & $100 \%$ & & & & \\
\hline Lasiurus borealis & & & & & & & & & & & & & & & \\
\hline Lasiurus cinereus & & & & & $33 \%$ & & $86 \%$ & & 1 & $39 \%$ & & 1 & $67 \%$ & $33 \%$ & 1 \\
\hline Myotis californicus & $98 \%$ & $100 \%$ & & $79 \%$ & $100 \%$ & & $19 \%$ & $46 \%$ & 6 & $100 \%$ & $100 \%$ & 4 & $53 \%$ & $92 \%$ & 3 \\
\hline Myotis ciliolabrum & & $20 \%$ & & & $71 \%$ & & & $20 \%$ & & $100 \%$ & $100 \%$ & 3 & $97 \%$ & $95 \%$ & 1 \\
\hline Myotis evotis & & & & & & & & & & & $24 \%$ & & & & \\
\hline Myotis lucifugus & & & & & & & & & & $20 \%$ & $100 \%$ & & & & \\
\hline Myotis thysanodes & & & & & $100 \%$ & 1 & $100 \%$ & $100 \%$ & 13 & $100 \%$ & $100 \%$ & 8 & $100 \%$ & $100 \%$ & 4 \\
\hline Myotis volans & & & & & & & & & 7 & & $19 \%$ & 1 & & & 2 \\
\hline Myotis yumanensis & $10 \%$ & $34 \%$ & & & $19 \%$ & & & & 2 & $39 \%$ & $58 \%$ & & & & 1 \\
\hline Parastrellus hesperus & $100 \%$ & $100 \%$ & 1 & $20 \%$ & $40 \%$ & 1 & $20 \%$ & $100 \%$ & 8 & $100 \%$ & $100 \%$ & 9 & $100 \%$ & $100 \%$ & 19 \\
\hline Tadarida brasiliensis & $86 \%$ & $33 \%$ & 3 & & $33 \%$ & 1 & & $33 \%$ & & $100 \%$ & $100 \%$ & 1 & $100 \%$ & $33 \%$ & \\
\hline
\end{tabular}

\begin{tabular}{|c|c|c|c|c|c|c|c|c|c|c|c|}
\hline \multirow{2}{*}{ Species } & \multicolumn{3}{|c|}{ August } & \multicolumn{3}{|c|}{ September } & \multicolumn{3}{|c|}{ October } & \multicolumn{2}{|c|}{ November } \\
\hline & $1-15$ & $16-31$ & Netting & $1-15$ & $16-30$ & Netting & $1-15$ & $16-31$ & Netting & $1-15$ & Netting \\
\hline Antrozous pallidus & & $24 \%$ & 2 & $24 \%$ & $48 \%$ & & & & 1 & & \\
\hline Corynorhinus townsendii & & & & & $100 \%$ & & & $74 \%$ & & & \\
\hline Eptesicus fuscus & $23 \%$ & & 1 & & $23 \%$ & & & $23 \%$ & 1 & & \\
\hline Euderma maculatum & & $86 \%$ & & & & & & & & & \\
\hline Eumops perotis & & & & & & & & & & & \\
\hline Idionycteris phyllotis & & & 1 & & & & & & & & \\
\hline Lasionycteris noctivagans & & & & & $23 \%$ & & & $67 \%$ & & & \\
\hline Lasiurus borealis & & & & & $38 \%$ & & & $19 \%$ & & & \\
\hline Lasiurus cinereus & $33 \%$ & $78 \%$ & & $78 \%$ & $33 \%$ & & $55 \%$ & $65 \%$ & & $32 \%$ & \\
\hline Myotis californicus & $98 \%$ & $100 \%$ & 3 & $19 \%$ & $100 \%$ & 3 & $99 \%$ & $99 \%$ & 7 & $99 \%$ & \\
\hline Myotis ciliolabrum & $76 \%$ & $20 \%$ & & & & & & & 1 & & \\
\hline Myotis evotis & & & & & $20 \%$ & & & & & & \\
\hline Myotis lucifugus & & & 1 & & & 1 & & & & & \\
\hline Myotis thysanodes & $100 \%$ & $100 \%$ & 5 & $99 \%$ & $99 \%$ & 7 & & $99 \%$ & 3 & & \\
\hline Myotis volans & $19 \%$ & & 1 & & & & & & 2 & & \\
\hline Myotis yumanensis & & $19 \%$ & 3 & & $27 \%$ & 1 & $19 \%$ & $19 \%$ & 1 & $8 \%$ & 1 \\
\hline Parastrellus hesperus & $100 \%$ & $100 \%$ & 9 & $100 \%$ & $100 \%$ & 3 & $100 \%$ & $100 \%$ & 1 & $99 \%$ & \\
\hline Tadarida brasiliensis & $100 \%$ & $97 \%$ & & $97 \%$ & $100 \%$ & 2 & $33 \%$ & $100 \%$ & 3 & $33 \%$ & \\
\hline
\end{tabular}




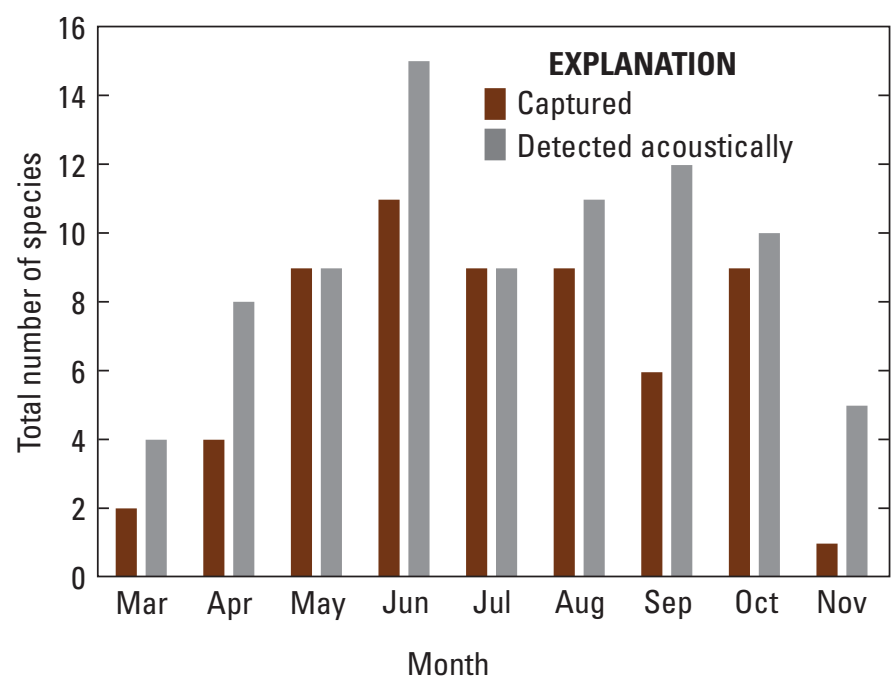

Figure 3. Graph comparing the total number of different species captured and acoustically detected each month within the 2011 and 2012 field seasons. Acoustic data is based on consensus count as determined by SonoBat software.

\section{References Cited}

Hayes, J.P., 1997, Temporal variation in activity of bats and the design of echolocation-monitoring studies: Journal of Mammalogy, v. 78, no. 2, p. 514-524.

Hinman, K.E., and Snow, T.K., eds., 2003, Arizona bat conservation strategic plan: Arizona Game and Fish Department Technical Report 213. [Also available online at http://www.azgfd.gov/pdfs/w_c/bat/NGTR $\% 20213 \% 20$ -\%20Arizona $\% 20$ Bat $\% 20$ Conservation $\% 20$ Strategic $\% 20$ Plan.pdf.]

McKoy, K.L., 2000, Cultures at a crossroads-An administrative history of Pipe Spring National Monument: National Park Service, Cultural Resources Selections no. 15, 793 p. [Also available online at http://npshistory.com/ series/archeology/rmr/15/index.htm.]

Quinn, H., Schweingruber, H., and Keller, T., eds., 2012, A framework for K-12 science education-Practices, crosscutting concepts, and core ideas: Washington, D.C., The National Academies Press, $400 \mathrm{p}$. 


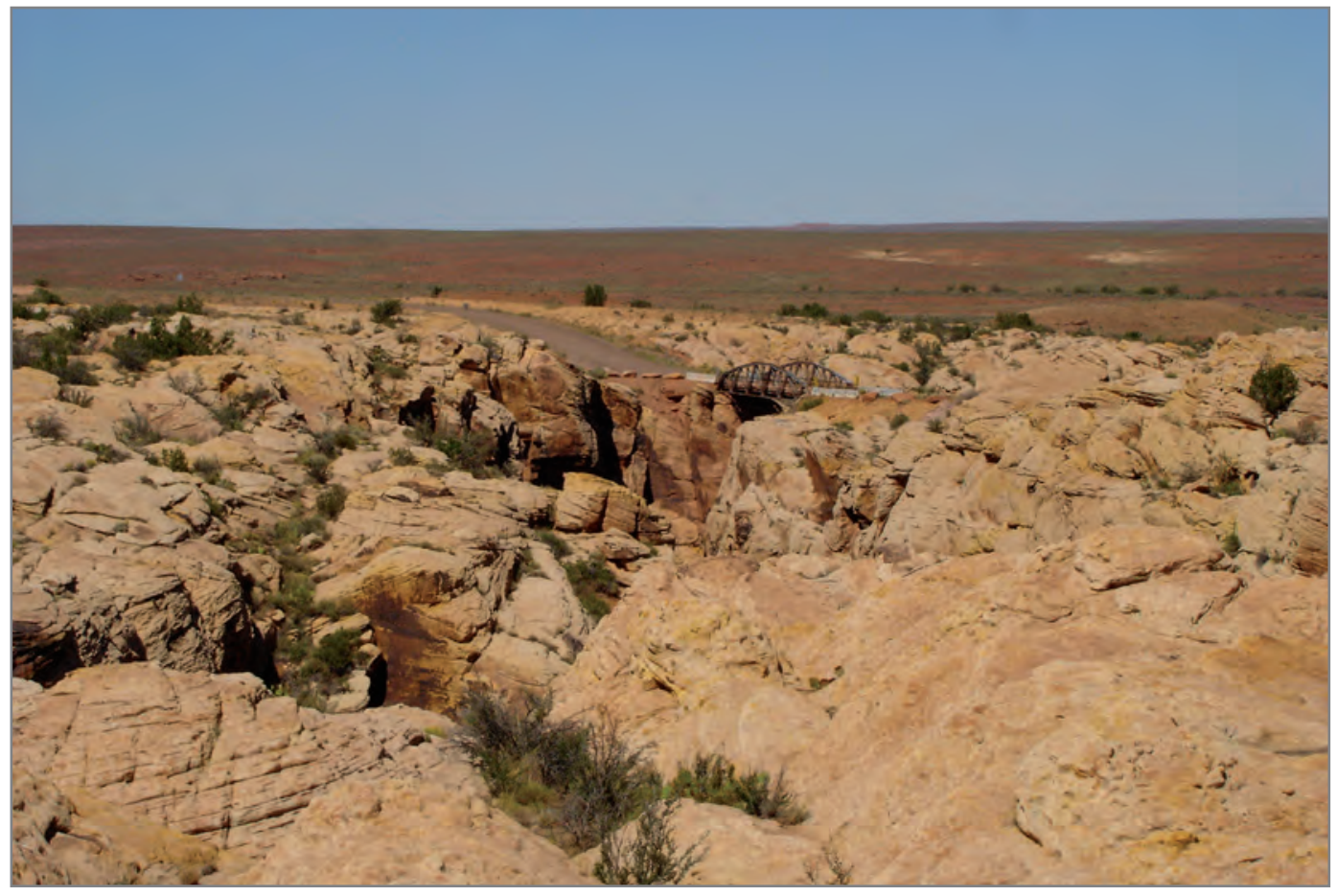

Chevlon Creek at Old Territorial Road. Photograph by Robert J. Hart, U.S. Geological Survey. 


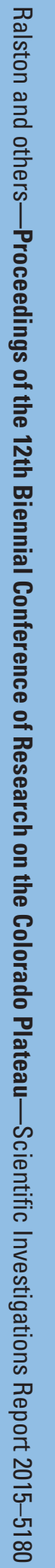

ISSN 2328-0328(online)

http://dx.doi.org/10.3133/sir20155180 